\title{
A 17. századi unitárius énekeskönyvek gyülekezeti énekanyaga és a 16. századi, 17. század eleji protestáns gyülekezeti énekhagyomány
}

\section{Doktori disszertáció}

SZTE BTK Irodalomtudományi Doktori Iskola

Szerző: Hevesi Andrea

Intézmény: SZTE BTK Irodalomtudományi Doktori iskola

EHA-kód: HEANABB.SZE

Témavezető: Szilasi László

Témavezető beosztása: egyetemi docens

\section{SZEGED}

2015 


\section{Tartalomjegyzék}

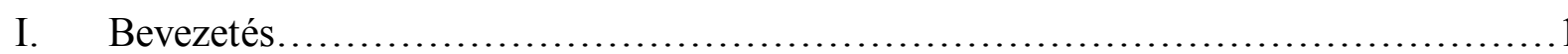

II. Az unitáriusok nyomtatott énekeskönyvei a 17. században..........................5

II. 1. Gyülekezeti énekeskönyvek..........................................6

II. 2. Ima-énekeskönyvek...............................................13

II. 3. Temetési énekeskönyvek.............................................. 18

III. A szövegösszevetések alapjául szolgáló nyomtatott és kéziratos források ismertetése.....21

III. 1. A nyomtatványok rövid leírása .......................................22

III. 2. A kéziratos források ismertetése ........................................ 31

IV. Incipitegyezés és textológiai kapcsolatok: a gyülekezeti énekek sajátos helyzete.......41

V. A szövegváltozatok jellemzése.............................................52

V.I. A gyülekezeti énekhagyomány apparátuskészletének, paratextusainak változásai

V. I. 1. Címváltozások, címadási jellemzők..................................54

V. I. 1. 1. A zsoltárszámozás a protestáns énekeskönyvekben................54

V. I. 1. 2. Az ,egyéb énekek” címadásának hagyománya....................66

V. I. 1. 3. A címadási jellemzők összegzése................................72

V. I. 2. Nótajelzést érintő változások ...................................... 73

V. I. 2. 1. A nótajelzések használatában bekövetkező változások összegzése..89

V. I. 3. Az apparátuskészlet, a paratextusok gyülekezeti énekgyüjteményen belüli változásának összegzése....................................................... 89

V. II. A gyülekezeti énekek szövegének változásai: néhány megfigyelés.............91

V. II. 1. A kolofon................................................... 92

V. II. 2. Az éneklő személye: E./1. és T./1 ....................................94

V. II. 3. Az akrosztichonok használata és szerepe a gyülekezeti énekekben..........104

V. II. 4. Strófacserék, strófák kivétele és betoldása a gyülekezeti énekek variánsaiban.............................................................. 107

V. II. 5. A rím és a ritmus változása a gyülekezeti énekben.......................110

V. II. 5. 1. Rímtoposzok és/vagy rímbokrok a gyülekezeti énekben?.............117

V. II. 5. 1. 2. Szava-sava-tava-java: egy nem tematikus rímbokor...........120 
V. II. 6. Értelemváltozások a gyülekezeti énekben: rontások, javítások, módosítások.................................................................... 124

V. II. 7. A bemutatott, szöveget érintő változások összegzése......................133

VI. Dogmatikai eltérések az unitárius anyagban...................................135

VI. 1. A protestáns hagyomány dogmatikai változásai...........................135

VI. 2. Protestáns szöveghagyomány - unitárius dogmatikával.....................137

VII. A csak antitrinitárius forrásokból ismert szövegekröl..............................146

VII. 1. Bogáti Fazakas-zsoltárok az unitárius hagyományban......................146

VII. 2. Lengyel zsoltárfordítások az unitárius hagyományban. Néhány apró

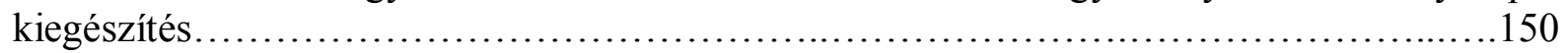

VII. 2. 1. A lengyel zsoltárfordítások helye az 1602-15 között nyomtatott unitárius énekeskönyvben............................................................... 152

VII. 2. 2. Apró mikrofilológiai adalék az RMKT 17/4. lengyel zsoltárfordításainak kiadásához. 155

VII. 2. 3. A lengyel forrású zsoltárok verstani, poétikai sajátosságai................158 zsoltárról.

VII. 3. Megfigyelések néhány ismeretlen szerzőjü, csak unitárius forrásban szereplő

VIII. Balassi-hagyomány a korai nyomtatványokban és kéziratokban....................169

VIII. 1. Az Istenes énekek hagyománya...................................... 170

VIII. 2. Az Istenes énekek szövegcsoportjairól.................................. 172

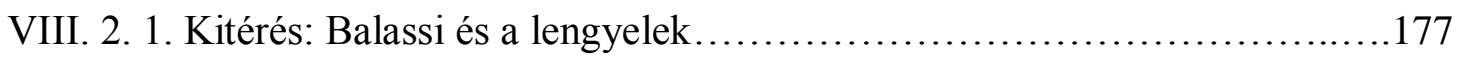

VIII. 3. A korai istenes témájú Balassi-szövegek néhány forrásáról.................180

VIII. 4. A korai Balassi-variánsok összevetése................................. 186

VIII. 4. 1. Bünös és/vagy bús? Az Ó, én kegyelmes Istenem... változatai.............186

VIII. 4. 2. A király, a bölcs és a mágus: a Pusztában zsidókat... változatáról.........188

VIII. 4. 3. Már, ma most. A Bocsásd meg, Úristen változatai..........................190

VIII. 4. 4. Szárnyát vagy szarvát? Az Adj már csendességet... korai variánsai.......193

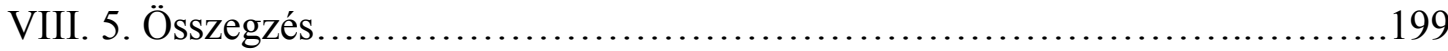

IX. A dolgozat összegzése, kitekintési lehetőségek................................200

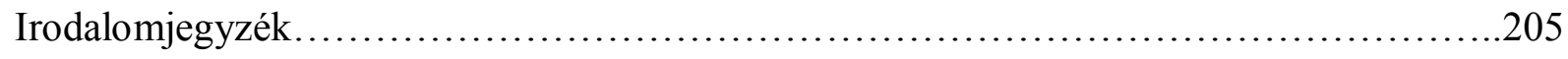

Melléklet: CD-mellékleten az 1602-15 közötti unitárius énekeskönyv átírt 118 gyülekezeti éneke, s annak összevetése a többi protestáns forrással. 


\section{Bevezetés ${ }^{1}$}

A dolgozat tárgya az 1602-15 között Kolozsvárt megjelent unitárius gyülekezeti énekeskönyv (RMNy 983) 118 gyülekezeti éneke. A dolgozat célja egyrészt az, hogy a nyomtatványban szereplő gyülekezeti énekeket elhelyezze a 17. századi nyomtatott és kéziratos unitárius énekhagyományban, illetve kiegészítéseket adjon a Régi Magyar Költők Tára 17. századi sorozatának 4. kötetében ${ }^{3}$ szereplő szövegekhez, azok jegyzeteihez.

Cél az is, hogy az unitárius énekhagyomány belső összevetésén kívül a protestáns énekhagyománnyal szembesítsük a gyülekezeti énekek unitárius változatait, s ismertessük azokat a tendenciózusnak tűnő változásokat, melyek a 16. század közepétől a 17. század első harmadáig a protestáns gyülekezeti énekhagyományban bekövetkeznek, s megfogalmazzuk az ezekből adódó következtetéseket.

A kutatás kiindulópontja az volt, hogy teszteljük a készülő 17. századi magyar vers adatbázisát. Az RPHA 17 egyik legfontosabb alapvetése ugyanis az, hogy nem főszöveget, egy általunk kiválasztott, valamilyen szempontból relevánsnak vélt szöveget veszünk fel „versnek,” hanem minden egyes szövegvariánst önálló versként tartunk számon, mely az adott szöveg többi variánsával kapcsolatban áll, ám ettől még egyedi jegyei is lehetnek, s ahogyan majd látjuk, a gyülekezeti énekkorpusz esetében szinte minden esetben vannak is. ${ }^{4}$ Tehát az RPHA 17 alapvető szövegfogalma az egy hordozón (kéziraton vagy nyomtatványon) található variáns $=$ egy rögzített, RMVA azonositóval ${ }^{5}$ rendelkezö szöveg. Arra voltunk kíváncsiak, hogy az RPHA 17 alapvetése, miszerint a verses szövegek variánsai külön rögzítendők, helytállóak-e, s a többletmunka kellő mennyiségü többleteredményhez vezethete.

Az kutatás alapvető módszere a szövegvariánsok összehasonlító közlése. Ez azt jelenti, hogy az 1602-15 közötti kolozsvári unitárius gyülekezeti énekeskönyv 118

\footnotetext{
${ }^{1}$ A dolgozat megírását az OTKA-K 109227 számú pályázata tette lehetővé. Témavezetőmön kívül köszönettel tartozom a véleményezésért, a tanácsokért és a bátoritásért Balázs Mihálynak, Keserü Gizellának és Ötvös Péternek.

${ }^{2}$ Régi Magyarországi Nyomtatványok, (1601-1635), II, Bp., Akadémiai, 1983,113-116. A kötetben szereplő adatokra a továbbiakban „RMNy+szám” alakban hivatkozunk.

${ }^{3}$ Régi Magyar Költök Tára 17. század, 4, Az unitáriusok költészete, kiad. Stoll Béla, TARNóc Márton, VARGA Imre, Bp., Akadémiai, 1967. A kötetre a továbbiakban RMKT 17/4-es rövidítéssel hivatkozunk.

${ }^{4}$ A megközelítést a Horváth Iván-féle „szöveg”-fogalomra alapozzuk, melynek mentén az RPHA 16 is dolgozott. HoRVÁTH Iván, Szöveg, http://magyar-irodalom.elte.hu/gepesk/bbom/tanulm/hiszoveg.htm (Letöltve: 2015. 09.01.) és az RPHA 16, http://rpha.elte.hu/ (Utolsó megtekintés: 2015. 09.01.)

${ }^{5}$ Az RPHA mintájára a verses szövegek számmal lesznek ellátva. A Régi Magyar Vers Adatbázisa rövidítés + szám jelöli az egyes hordozókon található szövegvariánsokat. Így minden $R M V A+s z a ́ m$ egyetlen szövegvariánst takar, nem föszöveget.
} 
gyülekezeti énekének ${ }^{6}$ szövegvariánsát főszövegben, modernizálva átírtuk, s a korábbi, illetve későbbi (a dolgozat későbbi fejezetében ismertetendő) nyomtatott és kéziratos protestáns énekgyüjteményeinek variánsaival az eltéréseket lábjegyzetben közölve összevetettük. Ezek, a protestáns variánsok eltéréseit mutató szövegközlések szolgáltak az elemzések alapjául.

Az RMNy 983, tehát a Kolozsvárt 1602 és 1615 között megjelent unitárius énekeskönyv gyülekezeti énekei lettek a kutatás alapszövegei. A kiválasztott anyag több szempontból is alkalmasnak tünt az alaposabb kutatásra. Egyrészt azért esett a korai unitárius nyomtatvány énekanyagára a választás, mert a gyülekezeti éneklésről, a gyülekezeti énekgyüjteményekről szóló monográfiákban és tanulmányokban a protestáns felekezetek közül az unitárius gyüjteményekkel foglalkoznak a legkevésbé annak ellenére, hogy a legkorábbi, a protestáns énekgyüjteményekről szóló szakirodalmak és szövegközlések között az unitárius szövegek szerepelnek. ${ }^{7}$

Másfelől az utóbbi időben az unitárius egyház kutatása felől is megfogalmazódott az igény, hogy az eszmei áramlatok, a müvelődéstörténeti események mellett a rítus, a szertartás és a közösségszervezés is elötérbe kerüljön. ${ }^{8}$ Pár évtizede az unitárius egyház történetének kutatása szinte kizárólagosan filozófiai, eszmetörténeti vizsgálatokra vállalkozott, ám a konfesszionalizáció tézisének megjelenésével előtérbe kerültek új megközelítések is. Ahogyan arra Balázs Mihály rávilágít, ${ }^{9}$ az unitarizmus a korábbi kutatások alapján elsősorban bölcselők gyülekezetének tünt, $\mathrm{s}$ a háttérbe szorult az egyházként való müködés hangsúlyozása. Ahogyan ez utóbbiak fontossága is világossá vált, úgy kezdődtek meg azok a kutatások, amelyek az egyház mint közösség szerkezetéhez, müködéséhez szükséges infrastruktúrák kialakulásával foglalkoznak. A lábjegyzetben említett úrvacsora-felfogás

\footnotetext{
${ }^{6}$ A dolgozat a továbbiakban gyülekezeti ének alatt az RMNy 983-ban a zsoltárrészben, és az egyéb énekeket tartalmazó, nem zsoltár típusú énekeket hozó részben található szövegeket érti. Noha a gyülekezeti ének fogalmába az ünnepi énekek is beletartoznak, a dolgozat ezek tárgyalásától több okból is kénytelen eltekinteni. Az első, praktikus ok a mennyiség: ha az ünnepi énekek is bekerülnek a vizsgálatba, az anyag megduplázódik, s terjedelmi okokból ekkora korpusszal a dolgozat nem számolhat. Fontos megemlíteni azt is, hogy az RMNy 983. ünnepi énekei több helyen csonkultak, így a szövegek összevetése is nehézségekbe ütközne. Másrészt úgy gondoljuk, az ünnepi énekek összehasonlító vizsgálata a dolgozat hangsúlyait más összetevők vizsgálatára helyezné át. Az ünnepi énekek vizsgálata a témánál fogva a dogmatikai változásokra kellene, hogy összpontosítson, hiszen a húsvéti, karácsonyi, pünkösdi ünnepkörhöz tartozó énekeket az unitáriusok elsősorban dogmatikailag szabták át. Emiatt a hangsúly a szövegváltozások nem dogmatikai okairól a dogmatikai okokra helyeződne át, amelyeket a dolgozat csak röviden érint a célkitüzésének megfelelően.

7 A korai protestáns énekanyag közül igen korán, a 1960-as, 1970-es években jelentek meg unitárius szövegközlések (az RMKT 17/4. kötete, és Bogáti Fazakas Miklós zsoltárai), ám azóta a protestáns gyülekezeti énekléssel kapcsolatos irodalmak csak igen ritkán, igen mellékesen említik az unitárius anyagot.

${ }^{8}$ Az úrvacsora kérdésével foglalkozik például KovÁCs Sándor, Das Abendmahl in der unitarischen Liturgie des 16. und 17. Jahrhunderts = Radikale Reformation, Die Unitarier in Siebenbürgen, Böhlau Verlag, Köln, Weimar, Wien, 2013, 241-28. (Studia Transylvanica 44).

9 BALÁzs Mihály, Az alkalmazás dilemmái, A német konfesszionalizációs modell és az erdélyi reformáció, Korall, 2014, 15.évf, 5-26.
} 
mellett fontos újdonság a gyülekezet által elmondott imádságok feltérképezése is, hiszen a gyülekezetiesedés egyik alapja az, hogy a hívek imádságban, énekszóban, közösen és magányosan is gyakorolhassák vallásukat. Ehhez szolgáltat az unitárius imádságok terén új adatokat Balázs Mihály, aki rámutat arra, hogy Heltai Gáspár imádságos könyve (15701571) ${ }^{10}$ már igen korán, a protestáns egyházak egy püspökség alá tartozása idején olyan személyes hangvételü, egyértelmüen a gyülekezet tagjainak közösségi és magánájtatosságát szolgáló kiadás volt, amely a hívek számára készült. Mint ilyen, Heltai imádságoskönyve tulajdonképpen az első, mely nem pusztán a szorosan a templomhoz kötődő vallásgyakorlást szolgálja. $^{11}$

Az unitárius egyház közösségszervezési, szertartásbeli alakulásának közvetlen elözményeként tekinthetünk Enyedi György énekléssel kapcsolatos véleményére is, melyet egy vita során fejtett ki, s e nyilatkozatban már körvonalazódik az a nézet, mely szerint szükség van az éneklésre. ${ }^{12}$

Az utóbbi néhány tanúságot fontosnak tartottuk felidézni, hiszen a kutatásunk anyaga illeszkedik az unitáriusok 16-17. századi szertartási, közösségszervezési, egyházként való müködési jellegzetességeit bemutató kutatásokhoz. Ám a 118 verses szöveget a magyar protestáns egyházak kontextusában vizsgáljuk, így a dolgozat elején le kell szögeznünk, hogy a radikális reformáció európai kontextusát figyelmen kívül hagyjuk, ahogyan azt is, hogy mi történik Kolozsvárott a társgyülekezettel, azaz a szász unitáriusokkal. ${ }^{13}$

A dolgozat vizsgálja a 118 gyülekezeti ének összehasonlító elemzése alapján azt, hogy milyen törvényszerüségek figyelhetők meg a protestáns gyülekezeti énekhagyomány szövegeinek változásában, illetve azt is, hogy ezek a törvényszerűségek mennyiben érvényesülnek az unitárius anyagban, esetleg az unitárius gyülekezeti énekek felmutatnak-e sajátosságokat a protestáns hagyományhoz képest. Mivel a gyülekezeti ének státusza is

${ }^{10}$ Heltai Gáspár imádságos könyve (1570-1571), közzéteszi BALÁzs Mihály, Erdélyi Unitárius Egyház, Kolozsvár, 2006 (Az Erdélyi Unitárius Egyház Gyüjtőlevéltárának és Nagykönyvtárának kiadványai 5).

${ }^{11}$ BALÁzS Mihály, Néhány megjegyzés Heltai imádságos könyvének utóéletéröl, Studia Litteraria , 2013/3-4. LII. évf. 298-317.

12 Enyedi György énekléssel kapcsolatos szöveghelyeit elemzi, s azt Radecius énekeskönyvének előszavával összefüggésbe hozza: Mihály, BALÁzS, Dogmatischer Radikalismus und Ritualkonservatismus im siebenbürgischen Antitrinitarismus (16-17. Jahrhundert), kéziratban. A későbbiekben Enyedi szöveghelye részletezve lesz, így ettől itt eltekintünk.

${ }^{13}$ A kolozsvári magyar és szász gyülekezetek kapcsolata, a nyelvi és politikai kérdések messzire vezetnének témánktól. Ezzel foglalkozik SzEGEDI Edit, Die Bedeutung des Ungarischen und Sächsischen im Klausenburg des 16. bis 17. Jahrhunderts = Radikale Reformation, Die Unitarier in Siebenbürgen, Böhlau Verlag, Köln, Weimar, Wien, 2013, 179-189. (Studia Transylvanica 44). Mivel Valentin Radecius énekeskönyve nem illeszthető a magyar nyelvü unitárius énekeskönyv-kiadások közé, így ennek részletezésétől is eltekintünk. Radeciussal, énekeskönyvével bővebben foglalkozik például SzEGEDI Edit, Valentin Radecius és az egyházi hagyomány legitimitása, Keresztény Magvető, 2011/3, 284-297. 
megvilágítást igényel, így az énekeket érintő változások értelmezése során olykor a közköltészetiesedési tendenciákat, az élöszóban elhangzás okozta lehetséges változásokat is figyelembe kell vennünk.

A dolgozatban igyekszünk egyrészt néhány kiegészítést, apró adalékot szolgáltatni a 17. századi nyomtatott unitárius énekhagyományhoz (például az első énekeskönyv datálási problémáihoz), illetve vizsgáljuk a csak unitárius forrásban található énekek poétikai és retorikai sajátosságait. Arra is keressük a választ, hogy az unitárius dogmatikai elvek hogyan érvényesülhetnek a protestáns gyülekezeti énekhagyományból átkerülő szövegeken.

Az unitárius énekgyüjtemény gyülekezeti énekeit összevetve a korábbi és a korabeli protestáns énekhagyománnyal a dolgozat igyekszik ismertetni néhány tendencia-szerünek látszó szövegváltozást. Keressük arra a választ, hogy a protestáns gyülekezeti énekeskönyvek szövegváltozatai milyen kapcsolatban állnak egymással: ábrázolható-e minden esetben stemmával, vagy esetleg másféle - nem csupán textológiai eredetű - kapcsolattal, hatással is számolnunk kell?

A protestáns szöveghagyomány kontextusában vizsgáljuk a 118 ének apparátuskészletének (cím, nótajelzés, szerkezet) változásait, és igyekszünk feltérképezni, hogy a 16. század közepétől a 17. század első harmadáig milyen jellemző szokások, tendenciák követésével alakult át az énekek ezen része.

Keressük a választ arra is, hogy a régi magyar vers tipikus jellemzői - pl. kolofon, akrosztichon, incipit, metrum és rím - hogyan állandósulnak, vagy éppen hogyan változnak meg a szük század folyamán a nyomtatott és a kéziratos hagyományban. Megnézzük, hogy egy-egy ének esetében az egyes strófák kikopása vagy betoldása milyen okokból következhet be, illetve azt, hogy vannak-e retorikai jellegü szövegváltozások.

A dolgozat utolsó fejezete a korai Balassi-szöveghagyománnyal foglalkozik, melynek egyik első forrása az általunk vizsgált unitárius énekeskönyv. A dolgozat a protestáns énekhagyománnyal kapcsolatban tett megfigyeléseit igyekszik alkalmazni a korai Balassivariánsokon, azaz azt vizsgálja majd, hogy a gyülekezeti énekhagyományban bekövetkező változási tendenciák megfigyelhetők-e ezeken a szövegeken is.

Az egyháztörténeti, a textológiai és a poétikai-retorikai sajátosságok párhuzamos figyelembe vétele miatt a dolgozat sajátos struktúrával rendelkezik. Narratívája, szerkezete alapvetően Lawrence Norfolk A Lempriére-lexikon ${ }^{14}$ című regényéhez hasonlítható, hiszen a gyülekezeti énekeskönyvek elbeszélésének különböző típusait tárjuk az olvasók elé, olyan

\footnotetext{
${ }^{14}$ Norfolk, Lawrence, A Lempriére-lexikon, ford. Gy. HorvÁth László, 2. kiadás, Bp., Athenaeum 2000 kiadó, é.n.
} 
típusait, amelyek olykor összeérnek, érintkeznek. Máskor viszont megszakad a folyamatos elbeszélés, s erre azért van szükség, hogy egy olyan kitérés jellegü, de el nem hanyagolható ismertetés kezdődhessen el, amely más szemszögből tekint az anyagra, és e nézőpont segítségével nyer ki új adatokat, legyen ez a nézőpont akár a gyülekezeti énekhagyományé, akár az unitárius egyháztörténeté.

Úgy gondoljuk, a kutatás alapjául szolgáló 118 unitárius gyülekezeti énekvariáns nem elhibázott választás egyrészt az említett hiányos irodalom miatt, másrészt az utóbbi időben előtérbe kerülő konfesszionalizmus-szempontú megközelítésmód miatt. Az unitárius énekanyag magyar protestáns hagyományba való elhelyezését indokolja az is, hogy a felekezeti szétválás igen lassan zajlik le, sőt, ahogyan azt látni fogjuk, bizonyos területeken (pl. Háromszéken) igen sokáig példás felekezetek közötti együttélésnek, együttmüködésnek lehetünk tanúi. Egy-egy felekezet különválása nem jelenti azt, hogy azonnal kialakult egyházi struktúrával, szertartásokkal és az ahhoz szükséges apparátussal fog rendelkezni, éppen ezért érdemesnek tartjuk összevetni a gyülekezet számára nagy jelentőséggel bíró énekeskönyvek anyagát, hiszen feltehetően sokáig érintkeztek, hatottak egymásra az egyes énekek.

\section{Az unitáriusok nyomtatott énekeskönyvei a 17. században}

A 17. századi, magyar nyelvü, kolozsvári kiadású unitárius énekeskönyvekről igen keveset tudunk. ${ }^{15}$ A protestáns énekeskönyvek hagyományához hasonlóan az unitárius énekeskönyvek esetében is két csoportot különböztetünk meg az általuk betöltött funkciók alapján. Számolnunk kell egy a templomi használatra szánt, gyülekezeti énekeskönyvtípussal, és egy magánhasználatra szánt ima- énekeskönyv-típussal. Ezen kívül beszélhetünk még halotti énekeskönyvekröl, amelyek a temetési szertartás során elhangzó énekeket tartalmazták.

A dolgozat csak a magyar nyelvü kolozsvári kiadású unitárius énekeskönyveket fogja tárgyalni, a szász unitárius gyülekezet énekgyüjteményeinek vizsgálatától eltekint, föleg azért,

${ }^{15}$ Jelen fejezet egy már megjelent tanulmány változata. HeVESI Andrea, RMNy 1615. Egy unitárius imaénekeskönyv töredéke, a többi 17. századi unitárius énekeskönyv tükrében, Keresztény Magvetö, 2013/4, 377390. 
mert a német nyelvü unitárius énekeskönyvek énekanyaga nem a magyar nyelvü énekanyaggal, hanem a szász evangélikus anyaggal mutat rokonságot. ${ }^{16}$

\section{1. Gyülekezeti énekeskönyvek}

A 18. században született első rendszeres unitárius egyháztörténet állítása szerint ${ }^{17}$ már Dávid Ferenc idejében is volt nyomtatott énekeskönyv, melyről azonban hiteles leírást nem ismerünk, így ennek vizsgálata nem kivitelezhető. A szöveghagyomány összevetése és a további kutatások során sem tudtunk felmutatni olyan adatot, amely alátámasztaná ennek a nyomtatványnak a meglétét.

A gyülekezeti énekeskönyvekből a 17. században három látott napvilágot, az első (RMNy 983) 1602 és 1615 között, ${ }^{18}$ a második 1632-ben (RMNy 1541), a harmadik pedig 1697-ben (RMK I, 1503).

\section{RMNy $9833^{19}$}

Az 1602-15 között megjelent énekeskönyvnek [Énekeskönyv - címet a címlap hiánya miatt nem ismerünk] két példánya ismert, mindkettő a marosvásárhelyi Teleki Tékában található, és sajnálatos módon mindkettő az elején és a végén is csonka.

${ }^{16}$ Erről bővebben: Péter, ÖTVÖs, Preussen christliche Lieder in der unitarischen Gemeinde von Klausenburg, Bemerkungen zu dem Thema Unitarier und Spiritualisten in Siebenbürgen = György Enyedi and Central European unitarism in the 16-17th centuries, ed. Mihály, BALÁzS; Gizella, KESERÜ, Bp., Balassi, 2000, 259268.

17 „Gyermekkoromban láttam a Dávid Ferenc idejében kiadott első énekeskönyv egy példányát, sőt a kezemben is járt ez néhai kolozsvári Takács István özvegyénél. [...] Ma azonban már annak a kiadásnak egyetlen példányát sem sikerült megtalálnom." KÉNOSI TÖZSÉR János - UZONI FOSZTÓ István, Az erdélyi unitárius egyház története I, ford. MÁRKOS Albert, a bevezető tanulmányt írta BALÁzS Mihály, sajtó alá rendezte Hoffmann Gizella, Kovács Sándor, MolnáR B. Lehel, Erdélyi Unitárius Egyház, Kolozsvár, 2005, 797.

${ }^{18}$ Az unitárius énekeskönyvek énekanyagát vizsgálva az RMNy adatai talán a legpontosabbak. (RMNy 983.) Az RMKT 17/4. 1605-07-es megjelenéssel számol, amit feltehetően VÁRFALVI NAGY János tanulmányából vesz át: Az unitáriusok énekes-könyveiről, Keresztény Magvető, 1871, 93-126.

${ }^{19}$ A dolgozat a továbbiakban erre az énekeskönyvre 1602-15 közötti kolozsvári unitárius kiadásként hivatkozik. Az összes forrást igyekszünk a dolgozatban a kiadás helye és éve alapján hivatkozni RMK vagy RMNy szám helyett, mivel a szövegösszevetések során úgy véljük, így könnyebben érthetők, könnyebben felidézhetők a források, mint az RMNy számok alapján. Az RMNy-en kívül a nyomtatvány részletes ismertetése: H. HUBERT Gabriella, A régi magyar gyülekezeti ének, Budapest, Universitas, 2004, (Historia Litteraria 17) 152-56, és RMKT 17/4. 531-33. 
Az első ismert nyomtatott unitárius gyülekezeti énekeskönyvvel kapcsolatban élesen vetődik fel a kérdés, hogy ha az unitárius nyomda a 17. század elején olyan rettenetes állapotban volt, hogy néhány rövidebb sajtóterméken kívül nem adott már ki semmit, akkor hogyan jöhetett ki éppen a nyomda felújítása, 1616 elött egy 560 oldalas énekeskönyv? A kérdést érdemes kicsit körbejárni.

Az RMNy állítása szerint ,[a] nyomtatvány a betütípusok tanúsága szerint a kolozsvári Heltai-mühelyben készült, mégpedig a kopott betük és az elmosódott nyomás alapján következtetve Makai Nyirö János 1616-ban végrehajtott felújítása elött."20

A terminus post quem pedig 1602, Újfalvi Imre református énekeskönyvének (RMNy 886) megjelenési ideje, mivel az RMNy 983 három olyan éneket is tartalmaz, amelyeket csak Újfalvi jelentetett meg korábban. ${ }^{21}$

A terminus post quem meghatározása az Újfalvi-féle énekeskönyv megjelenése miatt logikusnak látszik, ám a datálás kissé átgondolandó. A 17. század első éveiben való megjelenés feltételezése a Toroczkai-graduál történetének ismeretében válik kérdésessé. Ahogyan azt Stoll Béla bibliográfiában olvashatjuk Toroczkai Máté mára elveszett graduáljáról (S 1005), ${ }^{22}$ annak tartalmát csak Uzoni Fosztótól ismerjük. ${ }^{23}$ Ez alapján sejthető, hogy a graduál-rész azonos lehetett az általunk most tárgyalt első nyomtatott gyülekezeti énekeskönyvével (RMNy 983), Uzoni Fosztó állításai szerint az invokációk után 22 dicséret következett, tehát a graduál tartalmazott néhányat a templomban használatos gyülekezeti énekekből is. Az Egyháztörténet megemlíti továbbá azt is, hogy díszesen, igényesen kivitelezett kéziratról van szó, mely 1600-ban vagy 1601-ben keletkezett. ${ }^{24}$ Ha egy nagy értékü, sokba kerülő graduált készíttet az unitárius egyház, ${ }^{25}$ akkor valószínü, hogy előtte vagy éppen ebben az időben nem keletkezik nyomtatvány. ${ }^{26}$

\footnotetext{
${ }^{20}$ RMNy 983. (II kötet, 115.)

${ }^{21}$ Az RMKT 17/4. (532) szerint kettőt, de ezt kiegészíthetjük. A három ének a következő: Ilyen fogadást tőn Szent Dávid... (RPHA 573), a Mely hatalmas a mi urunk... (RPHA 867) és a Mostan, Úristen hozzád kiáltunk... (RPHA 1019)

${ }^{22}$ SToll Béla, A magyar kéziratos énekeskönyvek és versgyüjtemények bibliográfiája (1542-1840), Bp., Balassi, 2. kiad., 2002, 412-13.

${ }^{23}$ KÉNOSI-UZONI i.m., 797-801.

${ }^{24}$ KÉNOSI-UZONI, i.m., 797-98.

${ }^{25}$ A graduál készítéséről, annak költségeiről konkrét adatok is maradtak fenn 1600; 1601 tájáról. A kolozsvári számadáskönyvből idéz HeREPEI János, Adatok régi magyar versekről, ItK, 1962/4, 477-493 (477). Modernizált átiratban ez, a minden bizonnyal a Toroczkai-graduálról szóló bejegyzés a következő: „1600. június 22-én a graduált hogy íratni kezdtük, vettünk pergamentet hozzája, - $f l$ 7, den. 50. Ugyanannak írásához Bernard doktortól vettünk igen fekete tintát: Item mástól cinobriumot, berzsent, csendelyt-fl. 1, den. 41. November 23án a magyar kántor hogy a graduált írta a hártyára, fizettem neki fl. 8. Egy köböl búzát vettem neki - fl. 3 II 50."

${ }^{26}$ Azt sem zárhatjuk ki, hogy a kéziratos unitárius graduál éppen e nyomtatott kiadás előkészítésének céljával készült. Erre a reformátusoknál későbbi párhuzamot találunk az 1636-os Öreg garduál (RMNy 1643) és a kéziratos gyulafehérvári graduál kapcsán.
} 
Azt, hogy az RMNy 983 nem feltétlenül a század első éveiben keletkezett, az is alátámasztani látszik, hogy egy-két olyan gyülekezeti éneket is tartalmaz, amelyek ezen kívül legkorábban az 1602-14 között kiadott bártfai evangélikus énekeskönyvben (RMNy 965) jelennek meg, s ráadásul az RMNy 983-ban több olyan szövegváltozat is van, amely az 160214 közötti bártfai énekeskönyv variánsához áll a legközelebb. E kötet pontosabb kiadási ideje sajnos szintén bizonytalan, ám az RMNy szerint „,lehetséges, hogy az énekeskönyv Mihálykó János imádságoskönyvével (RMNy 976) egy évben, 1609-ben jelent meg. Az énekeskönyvet ugyanis két másik alkalommal hasonlóképpen az imádságoskönyvvel egy évben adták $k i .[\ldots]^{, 27}$ Ha ezt figyelembe vesszük, akkor nem kizárt, hogy az első nyomtatott unitárius gyülekezeti énekeskönyvet is 1609 utánra érdemes helyeznünk.

Az RMNy alapján azonban 1609 után, egészen 1616-ig a kolozsvári nyomdának egyetlenegy terméke kerül napvilágra hat év alatt. Az RMNy $1058^{28}$ ez a nyomtatvány, amely esetében azonban bizonyosan egészen rendkívüli körülmények között megjelent alkalmi kiadványról van szó, s megjelentését a politikai körülmények indokolhatták. A Rerum in Transylvania Anno Domini 1613. toto mense Octobri gestarum ordo et series címü, a címben jelzett események mellett az országgyülési határozatot is tartalmazó szövegegyüttest ugyanis úgy értelmezi az újabb szakirodalom, mint az erdélyiek által „féltükben szabadon” megválasztott új fejedelem, Bethlen Gábor politikai legitimációjára tett első kísérletet, amelyben ugyanakkor megragadhatók már a később bővebben kibontott érvelések alapvető mozzanatai is. Az újabb kutatások alapján az unitárius város politikai érdekeltsége is nyilvánvalóvá lett, hiszen kiderült, hogy az ebből a szempontból legfontosabb szövegrészlet, egy latin nyelvű epigramma szerzője nem református volt, mint korábban hitték, hanem az ifjabb Varsolci János, aki ekkor a kolozsvári unitárius kollégium segédtanára volt, s aki nyilvánvalóan a közösség képviseletében szólalt meg. ${ }^{29}$ Ezt követően csak a nyomdafelújítás után, 1616-tól van adatunk nyomdatermékről.

Említettük, hogy az RMNy a kopott betűk miatt véli 1616 előttinek a nyomtatványt. ${ }^{30}$ Dolgozatunk a későbbiekben, a csak unitárius forrásokban megtalálható énekekkel foglalkozó részében egy rövid kitérés során kifejti majd, hogy az RMKT 17/4. készítőihez hasonlóan az RMNy-csoport is a marosvásárhelyi Teleki Tékában található példányok mikrofilmes másolatát tudta csak használni, és az 1950-es években készült mikrofilm minősége nem a

\footnotetext{
${ }^{27}$ RMNy 965. (II. kötet, 966.)

${ }^{28}$ RMNy II. 178-79.

${ }^{29}$ Lásd erről a további szakirodalommal: BALÁzs Mihály, Varsolci János és Rettegi György ismeretlen szövegeiröl, ItK 117(2013), 5-11.

${ }^{30}$ RMNy 983. (II. kötet, 115.)
} 
legjobb. Kézbe vettük hát a Teleki Téka példányát, s megállapíthattuk, hogy ebben nem találkozunk alig olvasható, halvány betükkel. Így nem zárhatjuk ki azt sem, hogy ha nem is a már teljesen felújított nyomda terméke az énekeskönyv, de mindenképp egy részint már új betűkészlettel dolgozó nyomtatványról van szó. A kopottság mértékének megállapításában az RMNy-munkacsoport is a segítségünkre volt, $s$ a vizsgálatokat a szükséges kontrollanyagra is kiterjesztve immár általuk megtámogatottan is kijelenthetjük, hogy az RMNy 983 semmiképpen sem rettentő minőségü, kopott betüs nyomtatvány. ${ }^{31}$ A betük állapota alapján tehát megfogalmazható az a feltételezés, hogy a felújítás közben, 1616-ban látta meg a napvilágot ez a fontos nyomtatvány. (A felújítás folyamatára tett időzítést megerősíteni látszik, hogy megfigyelésünk szerint a kopottnak, régebbinek látszó $\mathrm{M}$, illetve erőteljes, újnak tünő M egyaránt található az énekeskönyvben.)

Az énekeskönyv invokációkkal kezdődik, amit egy A fö ünnepekre való énekek címü rész követ, ezután káté-énekek jönnek, majd a $12^{\circ}$ méretü nyomtatvány 194. oldalán , $A z$ David soltarabol bizonyos Enekek notajokra ki szedegetet Psalmusok következnek" alcímmel találkozunk. Itt 65 ének található. Ezt követi még a 428. oldaltól az ábécérendbe szedett, „,Szep külömb-külömb aitatos Dicziretek következnek” alcímmel ellátott rész, mely az ábécérendhez a végén hozzátoldott Balassi-verssel, az Adj már csendességet... kezdetűvel (RPHA 2007) az 560. lapon megszakad, innentől mindkét példány csonka. Ebben a részben 53 ének van, de a csonkasága miatt a terjedelem pontosan nem meghatározható. A dolgozatban tárgyalt 118 gyülekezeti ének az utolsó két fejezetben található, tehát a szöveghagyományt a zsoltárok és az egyéb énekek csoportján keresztül vizsgáljuk.

Az unitárius énekeskönyv-kiadások a 17. században - ahogyan a hiányos adatok ellenére ezt a jelen fejezet igyekszik majd bemutatni, - úgy tünik, a következő koncepció szerint alakultak: volt egy gyülekezeti énekeskönyv, mely tartalmazta a graduált, a zsoltárokat és az egyéb templomban használható énekeket. Ettől külön nyomtatva, de úgy tűnik, mindig pár éven belül megjelent a temetési énekeskönyv. E két énekeskönyv-típussal körülbelül egy időben mindig jelent meg magánhasználatra szánt kisalakú énekeskönyv is.

\footnotetext{
${ }^{31}$ A nyomdai kérdésekben V. Ecsedy Judit és Perger Péter személyes segítségére alapozott a dolgozat, hálás köszönet érte. Köszönettel tartozom Vadai Istvánnak is, aki segített az RMNy 983 és az 1632-es unitárius gyülekezeti énekeskönyv betütípusainak összehasonlításában.
} 
Ez a kiadási tendencia rokonítható Újfalvi Imre 1602-es református énekeskönyvkiadásának az előszavában felvázolt, általa ideálisnak tartott énekeskönyv-kiadási koncepcióval, mely a következőképp alakul: ${ }^{32}$

I. Énekeskönyv:

1. Graduál

2. Zsoltárok

3. Egyéb énekek

4. Halotti énekek

II. Egyéb kiadásban: nem templomba való vallási énekek

Látható, hogy Újfalvi Imre kiadása, illetve az előszavában említett ideálisnak vélt kiadási tendenciák hasonlóak az unitárius kiadási szokásokkal, azzal a különbséggel, hogy az unitáriusoknál a temetési énekek mindig külön nyomtatványban szerepelnek, ${ }^{33}$ illetve az Újfalvi Imre vázolta eszményi kiadásban mind a 150 zsoltárnak szerepelnie kellene (noha ez érthető okokból - még nála sincs meg). Fontos azt is megjegyezni, hogy az RMNy 983, tehát az első nyomtatott unitárius gyülekezeti énekeskönyv a zsoltárokat a későbbi unitárius kiadásokkal ellentétben még nem ábécérendben közli, hanem szám szerint növekvő sorrendben, ugyanúgy, ahogyan a többi protestáns énekeskönyv-kiadás többsége is. Ezáltal az első unitárius nyomtatvány(ok) szerkezete, sajátosságai nem állnak olyan messze a protestáns hagyománytól, mint ahogyan azt gondolni szoktuk.

Újfalvi Imre életének bizonyos szakasza egyébként is kapcsolatba hozható a kolozsvári unitáriusokkal, amelyet talán nem felesleges megemlítenünk.

Bod Péter feljegyzései szerint Újfalvi, miután Hodászi Lukács számüzeti, „az idegen földön nyomorultul hólt meg," s ezt az idegen földet a szakma sokáig a Moldvai Fejedelemségnek gondolta. Mára már nagyon valószínű, hogy ezt az adatot Bod Péter találta ki. Schulek Tibor $^{34}$ viszont más megvilágításba helyezi Újfalvi pályájának utolsó éveit: Újfalvi ugyanis 1615. június 15-16-án az evangélikusoktól kér segítséget, az Ötvárosi Egyházmegyéhez folyamodik Eperjesen, hogy érjék el Bethlennél a számkivetés alóli

\footnotetext{
${ }^{32}$ Terjedelmi okokból Újfalvi Imre előszavát nem részletezzük. Erről, illetve az Újfalvi-féle koncepció és az unitárius kiadási szokások kapcsolatáról bővebben: HEVESI Andrea, Újfalvi Imre: egy protestáns értelmiségi karrier a 16-17. század fordulóján = Értelmiségi karriertörténetek, kapcsolathálók, irócsoportosulások, szerk. BiRó Annamária-BOKA László, Nagyvárad - Budapest, Partium Kiadó - reciti, 2014, 31-40.

${ }^{33}$ Újfalvi Imre 1598-ban külön is kiadja a temetési énekeket (RMNy 832), és fontos megjegyezni, hogy az 1602es énekeskönyvben is (RMNy 886) külön címlappal szerepelnek nála a temetési énekek. Az elkülönítés oka feltehetően a praktikum: a temetési énekeket elsősorban a kántor és a temetésen éneklő iskolások használták.

${ }^{34}$ SCHULEK Tibor, Még néhány szó és egy új adat Szilvásújfalvi Imréröl = Szenci Molnár Albert és a magyar késő-reneszánsz, szerk. CSANDA Sándor, KESERŰ Bálint, Szeged, 1978, 293-96 (295) (Adattár 4).
} 
feloldást. A polgári követek vállalják, hogy írnak a fejedelemnek, de ennek eredményességéről nem maradt fönn semmiféle dokumentum.

Újfalvi életének legutolsó fennmaradt adata viszont Kolozsvárról származik, ezután semmit sem tudunk róla. ${ }^{35}$ A kolozsvári városi számadás-könyvbe 1616. február 2-án a kolozsvári sáfárpolgár, Ombozi Pál, azt jegyezte be, hogy az unitárius „Bíró uram hagyásából szegény prédikátornak, melyet a religióért rabságban tartottanak az ellenkezö atyafiak, annak elszabadulván adtam borra, húsra és kenyérre fl[orenos] 26." A lap szélén más, de ugyanabból a korból származó kézírással be van jegyezve: „Emericus Wj faluj." Ugyanabban a számadáskönyvben másnap, február 3-án még egy beírás van: „Adtam ismét az szegény prédikátornak B[iro] V[ram] h[agyásából] ételre és italra való költségekre tt fl[orenos] $16 .{ }^{136}$

Ez a bejegyzés azért is igen érdekes, mert tudható, ${ }^{37}$ hogy ezekben az években egy kőműves mesterember 10 napi munkájáért 2 forint 50 denárt kapott. Sőt, a kolozsvári számadáskönyvek szerint az oda látogató munkások, legyenek azok akár könyvkötők is, (ami akkoriban igencsak megbecsült szakma volt,) nem kapnak többet élelemre és borra egy forintnál. Az Újfalvinak adott összeg tehát feltűnően magas, ám ezzel az igen érdekes adattal gyakorlatilag el is veszítjük őt a szemünk elöl.

Ha elfogadjuk, hogy az RMNy 983 1616-ban keletkezett, nem 1602-15 között, akkor érdemes a felvázolt szerkezeti sajátosságok miatt azt is megemlíteni, hogy Újfalvi Imre 1616 februárjában az unitáriusoktól kap Kolozsvárott 42 forintot. Ez akkoriban igen nagy összeg, így az énekeskönyvek hasonlósága és a történeti dokumentum alapján talán feltételezhetjük, hogy Újfalvinak az első unitárius gyülekezeti énekeskönyv megjelenésében is szerepe lehetett, bár ezt a szerepet valószínüleg soha nem ismerhetjük meg pontosan, minden kétséget kizáróan nem fogjuk tudni megerősíteni.

\footnotetext{
${ }^{35}$ Azt meg kell említeni, hogy Újfalvinak antitrinitárius kapcsolatáról is van tudomásunk: Petki Jánossal tart kapcsolatot.

${ }^{36}$ VISKY István, Szilvásújfalvi Imre pere, A 17. századi váradi református egyházkormányzati reformmozgalom története, Várad, 2004./3. 3. évf. Interneten: http://epa.oszk.hu/00100/00181/00013/23.htm (Letöltve 2013.06.04.)

${ }^{37}$ JENEY-TÓTH Annamária, Míves emberek a kincses Kolozsvárott, Erdélyi Múzeum Egyesület, Kolozsvár, 2004.
} 


\title{
RMNy $1541^{38}$
}

Az 1602-15 közötti gyülekezeti énekeskönyvnek - föként Thordai zsoltárokkal és egyéb, 17. századi darabokkal - bővített kiadása az 1632-es kiadás, (RMNy 1541, címe: Isteni dicséretek, imádságos és vigasztaló énekek) melynek mérete szintén tizenkettedrét, és a szerkezete is igen hasonló az előzőhöz, és Heltai nyomdájában adják ki. Az első rész előtt egy mottó található, a 80 . zsoltárból: ${ }^{39}$

\author{
Uram, Seregeknek Istene med- \\ dig haragszol az te népednek kö- \\ nyörgésére? \\ Seregeknek Istene, vigasztaly \\ meg minket, és fenlyék mi nékünk \\ az te ortzád, és meg szabadulunk. "40
}

A kötet a graduál-résszel kezdődik, majd a 228. oldaltól „Az Szent David sóltárából, bizonyos Énekek notájára ki szedegetet Psalmusok, és külömb-külömb üdökre valo Ditsiretek, következnek az ABC rendi szerént." Ezen már látszik a bővítés: 94 éneket tartalmaz. Ezt még követi a 607. oldaltól egy vegyes zsoltár- és énekrész, imádságokkal kiegészülve, mely az ábécérendet újrakezdi, s ide bővítményeket, toldalékokat helyez. Ebben 53 darab ének, zsoltárparafrázis és ima található, de ezek nem azonosak (pontosabban csak részben azonosak) az előző énekeskönyv 53 darabjával.

Ezt a gyülekezeti énekeskönyvet Abrugyi György adja ki, de évszám nélkül. Az RMKT 17/4. ${ }^{41}$ az egyéb unitárius kiadványok közül 1632-ben megjelentek alapján következtet arra, hogy ezt az énekeskönyvet is az 1632-es évre tehetjük.

\footnotetext{
${ }^{38}$ Az RMNy-en kívül részletes ismertetése: H. HUBERT, i.m., 176-177 és RMKT 17/4. 536-38. A továbbiakban ezt az énekeskönyvet az 1632-es unitárius gyülekezeti énekeskönyvként hivatkozzuk.

${ }^{39}$ Ki kell emelnünk, hogy ez a mottó a korabeli énekgyüjtemények mottóhasználatától merőben eltér. Míg a bevett szokás az, (ld. H. HuBERT, i.m.) hogy az éneklés módjával, minőségével kapcsolatos mottókat tesznek a kötet élére, addig ez nem foglalkozik a kérdéskörrel.

${ }^{40}$ Eddig csak a kolozsvári példányokat sikerült kézbe venni, ezek csonkák az elején, de Török Ferenc kézzel kipótolta a hiányzó részeket: „,[a] kolozsvári ev. ref Fötanoda teljes példánya után készítette,” 1862-ben. (Az idézet a Török Ferenc által betoldott, nem számozott lapokon , a kolozsvári Akadémiai Könyvtár példányában található, jelzete: B.M.V. U: 168.)

${ }^{41}$ RMKT 17/4, 536.
} 
RMK. I. $1503^{42}$

Az 1638-as dézsi complanatio miatt hosszú időre szünetel az énekeskönyvek kiadása, így a következő, a században utoljára kiadott gyülekezeti énekeskönyv megjelenési ideje 1697 (RMK I. 1503). Ez az énekeskönyv még tovább bővül, főként 17. századi darabokkal. A $12^{\circ}$ méretü kiadás címlapján a következőket olvashatjuk: „Isteni dicsiretek, imádsagos és vigasztalo énekek, Mellyek most ujjobban jó rendben vétettek, és az elébeni fogyatkozásoknak megjobbittatásával kibocsáttattak Kmita Andrásné Költségével. Kolozsvárat, Az Unitária Ecclesia betüivel Liszkai Mihály által Anno 1697.” Ezt követően mottóként itt is a már az 1632-es kiadásban is szereplö, az Uram, seregeknek Istene... kezdetü 80. zsoltár van megadva. Az énekeskönyv felépítése hasonló az előzőekéhez: a graduál-rész után, a 164. oldalon a következő alcímet találjuk: „Az Szent David soltarabol, bizonyos énekek nótájára ki szedegetett psalmusok, és külömb külömb üdökre valo Dicsiretek, következnek az ABC rendi szerént." E részben összesen 85 ének van, majd ezt egy TOLDALEK T.I. címü rövid alfejezet követi, melyben két zsoltár található Thordai Jánostól, az egyik a 139., az Ártatlan szívét Szent Dávid... kezdetű, a másik pedig a 143., az Igaz látó szent Úristen... kezdetű. Ezt követően még találunk egy másik részt is, mint a többi gyülekezeti énekeskönyvben is: a 440. oldaltól összesen 69 darab ének, imádság és zsoltárparafrázis olvasható ábécérendben. ${ }^{43}$

\section{2. Ima-énekeskönyvek}

H. Hubert Gabriella álláspontja szerint feltételezhető, hogy a graduált is tartalmazó, számos zsoltárt és egyéb éneket is közlő énekeskönyvek gyülekezeti használatra születtek, míg a rövidebb, 30-40 éneket közlő nyomtatványok a magánhasználati igények kielégítésére utalnak. $^{44}$

\footnotetext{
${ }^{42}$ Az RMK-n kívül leírása: H. HUBERT, i.m., 247-48 és RMKT 17/4. 538. A továbbiakban erre a kiadásra az 1697-es kolozsvári unitárius énekeskönyvként hivatkozunk.

${ }_{43}^{43}$ Talán nem felesleges megemlíteni, hogy az egyik kolozsvári példány ebböl a kiadásból egybe van kötve Szenci Molnár Albert 150 zsoltárának 1712-es kolozsvári kiadásával, minden bizonnyal korabeli kötéssel. Ekkoriban, az 1710-es években tehát minden bizonnyal az unitáriusok is használták már a Szenci-zsoltárokat. (Korábbról kézzel fogható, bizonyos adataink nincsenek.)

${ }^{44}$ H. HUBERT, i.m., 255.
} 
Ebből a második típusból minden bizonnyal volt már kiadás a 16. század végén is. Az RMNy 746-os ${ }^{45}$ számú kiadványa ez, amely 1592-97 között keletkezhetett, mikor Enyedi György unitárius püspök volt. A kötet igen kis terjedelmü, ezért inkább mondható néhány ének gyüjteményének, mint énekeskönyvnek. ${ }^{46}$ Noha a nyomtatvány éneklistája nem maradt fönn, azt megállapíthatjuk, hogy a későbbi ima-énekeskönyvekben szereplő énekek többsége szerepel már az 1602-15 közötti gyülekezeti énekeskönyvben, illetőleg jórészt 1590 után keletkezett szövegekből áll, így nem valószínü, hogy ez a kis gyüjtemény lehet a forrása a későbbi ima-énekeskönyvek énekanyagának. Azt azonban érdemes hangsúlyozni, hogy az 1570-71-ben megjelent imádságos könyv $^{47}$ és ez a mára elveszett, feltehetően magánhasználatra szánt énekgyüjtemény az 1590-es évekből arról tanúskodnak, hogy az unitárius felekezet számára igen korán, már a 16. század utolsó harmadában fontossá vált a magánájtatosságot lehetővé tevő kiadványok megjelentetése.

\section{RMNy $1290^{48}$}

A magánhasználatra szánt énekeskönyvekből eddig két kiadást ismertünk a 17. századból. Az egyik a mára elveszett, 1623-as kiadás, (RMNy 1290) melyet Várfalvi Nagy János tanulmánya ${ }^{49}$ ismertet, és az énekek mutatóját is közli. Várfalvi Nagy szerint ez az énekeskönyv 30 éneket tartalmazott. Nem önállóan jelent meg, egybe volt kötve Várfalvi Kósa János Cathechismusával, illetve egy imádságos könyvvel, melynek címe: „Imadsagos Könyveczke. Melyet naponkent olvashat minden rendbeli Keresztyen ember. A. D. 1623.”

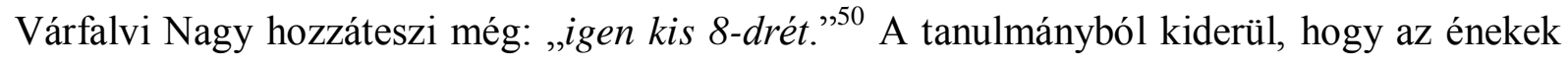
betürendes mutatója után még egy mondat található: „Az enekek elöt vagyon harom rendbeli könyörges.” A közös címlapot ill. az énekeskönyv címlapját nem írja le Várfalvi Nagy.

\footnotetext{
${ }^{45}$ Az RMNy ismertetésén kívül bővebben: H. HUBERT, i.m., 254-55.

${ }^{4}$ A kötetről bővebben KANYARÓ Ferenc ír: Enyedi György unitárius püspök beszéde, Keresztény Magvető, 1900, 30-40. Enyedi éneklésről írott prédikációját közli: H. HUBERT, i.m., 379-89.

${ }^{47}$ Heltai Gáspár imádságos könyve (1570-1571), közzéteszi BALÁzS Mihály, Erdélyi Unitárius Egyház, Kolozsvár, 2006 (Az Erdélyi Unitárius Egyház Gyüjtőlevéltárának és Nagykönyvtárának kiadványai 5) és BALÁzs Mihály, Néhány megjegyzés Heltai imádságos könyvének utóéletéröl, Studia Litteraria , 2013/3-4. LII. évf. 298-317.

${ }^{48}$ A továbbiakban 1623-as unitárius ima-énekeskönyvként hivatkozik rá a dolgozat. Példány nem maradt fönn. Az RMNy-en kívül ismerteti: H. HuBERT i.m., 255. ill. VÁRFALVI NAGY János, Az unitáriusok énekeskönyveiről, Keresztény Magvető, 1871, 93-126, az RMKT 17/4. csak említés szintjén ír róla: 528.

${ }^{49}$ VÁRFALVI NAGY János, Az unitáriusok énekes-könyveiről, Keresztény Magvető, 1871, 93-126.

${ }^{50}$ VÁRFALVI NAGY János, i.m., 123.
} 


\section{RMNy $1615^{51}$}

Az RMNy 1615. számú makulatúrájáról egy tanulmányában Fekete Csaba ${ }^{52}$ megemlíti, hogy minden bizonnyal unitárius magánhasználatra szánt ima-énekeskönyv töredéke lehet. Valóban minden jel arra mutat, hogy ez a töredék unitárius, s talán érdemes megvizsgálni, miből következtetünk erre.

A $32^{\circ}$ méretű makulatúrán egy nyomtatvány első 15 levele található, közöttük maga a címlap is. Ebből kiderül, hogy Abrugyi György nyomtatta Kolozsvárott, 1635-ben.

A kiadvány címe pontosan megegyezik az 1700-as imádságos és énekeskönyvével: „Imadsagos es enekes, kézbe hordozó Könyveczke. Mellyet naponként minden rendbéli Keresztyén ember olvasgathat. Nyomtatta Colosvárban Abrugi György 1635."

A makulatúra 15 levelének egy része sajnos olvashatatlan. Kiolvasható a nyomtatvány címlapja, egy alcíme, és az Adj már csendességet... kezdetü (RPHA 2007) Balassi-ének egy része, illetve az Aki veti segedelmét... kezdetű zsoltárparafrázis (RPHA 74) egy részlete. Az őrszavakból kiderül, hogy az Adj már csendességet... után következett az Aki veti segedelmét... kezdetű ének. Ebből már következtethetünk arra, hogy az énekek ábécérendben lehettek.

Korábbi tanulmányunkban bemutattuk, ${ }^{53}$ hogy a nyomtatványon szereplő két ének variánsa egyértelműen minden ponton azonos az 1700-ban kiadott unitárius magánhasználatra szánt énekeskönyv variánsával, illetve az unitárius nyomtatványok szövegváltozatával, így a filológiai vizsgálatok is azt mutatják, hogy az RMNy 1615 egy 1635-ös kiadású unitárius imaénekeskönyv töredéke.

Ezeken kívül kivehető három könyörgés részlete is. Az első a Mi Atyánkkal ér véget. A dolgozat magánhasználatra szánt énekeskönyveket tárgyaló részében ismertettük, hogy

${ }^{51}$ Az RMNy ismertetésén kívül Fekete Csaba szól róla (ld. a következő hivatkozást). H. Hubert Gabriella monográfiája nem ismerteti az ima-énekeskönyveknél, az RMKT 17/4. jegyzete sem ír róla. A továbbiakban ezt a makulatúrát az 1635-ös unitárius ima-énekeskönyv töredékeként hivatkozza a dolgozat.

52 FeKeTE Csaba, A 16-17. század legkisebb imádságoskönyve = Régi magyar imakönyvek és imádságok, Pázmány Irodalmi Műhely, Lelkiségtörténeti tanulmányok, szerk. BOGÁR Judit, Pázmány Péter Katolikus Egyetem, Bölcsészet- és Társadalomtudományi kar, Piliscsaba, 2012, 91-103. https://btk.ppke.hu/uploads/articles/19896/file/regi_magyar_imakonyvek_es_imadsagok.pdf A letöltés ideje: 2015. 09.01.

Ez tanulmány csak mellékesen említi a nyomtatványt, mert elsősorban a kis méretű, evangélikus imakönyvekkel foglalkozik.

${ }^{53}$ Hevesi Andrea, i.m., KerMagv, 2013/4, 377-390. 
Várfalvi Nagy tanulmánya szerint az 1623-as elveszett ima- énekeskönyv elején is három könyörgés volt olvasható, melyet az 1700-as újrakiadás lecserélt az ifjúságnak szóló öt regulára. Erős tehát a gyanú, hogy az 1623-as nyomtatvány három könyörgését közli az RMNy 1615 is. A könyörgések részleteiből pedig egyértelmüen kivehető, hogy azok közül egy magyar nyelvü Enyedi-imádság lehet. ${ }^{54} \mathrm{Az}$ imádságok előtt előszó is volt, ezek a lapok a makulatúrán szinte olvashatatlanok. A következőket lehet elolvasni:

De még-is etiam [?] akarom annak [?] jelet mutatni, es ez könyvetsket te Kegyelmeteknek dedicálni, ez vegre: tudván azt hogj az [?] Kegyelmetektöl származot Rajotskák, az idegen helyekre ki terjedvén az Sz. Lélek dajkálkodásában s[?] lelki eledelt ohaytvan nagy kedvesen veszik elö.

Kiderül tehát, hogy a század legkisebb, $32^{\circ}$ méretủ unitárius magánhasználatra szánt énekeskönyvének az unitárius énekeskönyv-kiadási szokástól eltérően volt dedikációja, ${ }^{55}$ de nem tudjuk, ki lehetett a címzett. Az bizonyos, hogy a „kegyelmeteknek” nevezett címzett által idegen helyekre küldött csoportoknak szánja a szerkesztő az énekeskönyvet. Arra nézvést azonban nincs adatunk, hogy az idegen helyen tartózkodók miért, hová mentek. Elképzelhető, hogy esetleg egy a peregrinánsokat támogató személy a címzett, s vele a peregrináló diákok, de az sem lehet kizárt, hogy esetleg a hódoltsági területekre induló unitáriusokat célozza meg az énekeskönyv. A többitől eltérő, kisebb nyomtatvány előállításának is nyilván a praktikum, a könnyű hordozhatóság volt az oka.

A makulatúrán teljesen olvasható egy alul és fölül is díszítő motívummal ellátott lap, melyen a 80. zsoltár parafrázisa található, - az Uram, seregeknek Istene ... kezdetü, - középen, mottóként, mint az 1632-es és az 1697-es unitárius gyülekezeti énekeskönyvekben is. Sőt, Várfalvi Nagy állítása szerint már az 1602-15 körüli énekeskönyvben is ez a mottó szerepelt, csak sajnos ez ma már csonka az elején. ${ }^{56}$

\begin{tabular}{|c|c|}
\hline 1697. (RMK I. 1503) & 1635. (RMNy 1615) \\
\hline Uram, Seregeknek Istene med- & PSALMUS LXXX. \\
dig haragszol az te népednek kö- & Uram, Seregeknek Istene, meddig \\
nyörgésére? & \\
\hline
\end{tabular}

\footnotetext{
${ }^{54}$ Az észrevételt és az azonosítás során nyújtott segítséget köszönöm Lovas Borbálának.

55 A 17. századból unitárius énekeskönyv-előszó csak egy van ezen kívül: az 1697-es gyülekezeti énekeskönyv (RMK I. 1503) tartalmazott előszót, de konkrét dedikációt vagy ajánlást az sem.

${ }^{56}$ VÁRFALVI NAGY, i.m., 116.
} 


\begin{tabular}{|c|c|}
\hline Seregeknek Istene, vigasztaly & Seregeknek Istene, vigasztaly meg \\
meg minket, és fenlyék mi nékünk & minket, es fénlyek mi nékünk az te orczád: és \\
az te ortzád, és meg szabadulunk. & meg szabadulunk. \\
& \\
\hline
\end{tabular}

Látható, hogy a szövegváltozatok teljesen megegyeznek, néhány szó írásképének a kivételével. Ezen a lapon az őrszó a SZEP, tehát utána következik az alcímet tartalmazó lap, amelyen az Adj már csendességet... (RPHA 2007) is elkezdődik. Ennek a versnek a címe az, ami az 1700-as kiadású, magánhasználatra szánt unitárius énekeskönyvben is: Békességkérö ének.

A nyomtatványon belül az énekrész alcíme a következő: Szép Isteni Ditsiretek és háláadások. A dolgozat elején ismertetett ima- énekeskönyveknél láthattuk, hogy Várfalvi Nagy szerint az 1623-asban is ez az alcím szerepelt, de az 1700-as magánhasználatra szánt énekeskönyv alcíme is ez: Szep isteni ditsiretek és háláadások. Az eddig ismertetett anyagok tükrében úgy tűnik, az RMNy 1615-ös számú makulatúra minden bizonnyal egy unitárius ima-énekeskönyv töredéke lehet.

RMK I. 1558-59

Az 1623-ban kiadott, mára elveszett imádságos és énekeskönyvnek (és az RMNy 1615-nek) ismerjük az 1700-as, bővített, $12^{\circ}$ újrakiadását is. (RMK I. 1558-59.) Ennek címe: „Imadsagos es enekes kézbe hordozo Könyvetske. Mellyet naponként minden rendbéli Keresztyen ember olvasgathat. Kolosvarat. Az Unitária Ecclesia Typusival, 1700ben." E kötetnek a Várfalvi Nagy János által ismertetett 1623-assal nagyon hasonló a felépítése: a föcím alatt Szep isteni ditsiretek és háláadások címmel összesen 66 darab éneket, és zsoltárparafrázist találunk. Ehhez, csakúgy, mint az 1623-as kiadáshoz, hozzá volt kötve egy imakönyv, és Várfalvi Kósa János kátéja is. ${ }^{59}$

\footnotetext{
${ }^{57}$ A Török Ferenc által kézzel írt, betoldott, nem számozott lapokon található a mottó, a kolozsvári Akadémiai Könyvtár példányában, jelzete: B.M.V. U: 168.

${ }^{58}$ Az RMK-n kívül ismerteti: H. HUBERT, i.m., 261, s az RMKT 17/4. csak említés szintjén ír róla: 528. A továbbiakban az 1700-as kiadású unitárius ima-énekeskönyvként hivatkozunk a nyomtatványra.

${ }^{59}$ H. HuberT, i.m., 261.
} 
Ennek az énekes résznek az elején a mottók már nem a 80. zsoltárból valók, és az 1623-as ima-énekeskönyv három könyörgése helyett az ifjúságnak szóló „öt regula” olvasható a kötet elején, címe: „Keresztyéni ájtatosságra való gerjesztés,” ami tulajdonképpen a mindennapi kegyesség alkalmait, módjait írja le tömören. Az énekek itt is betürendben vannak, de az ábécé kétszer kezdődik el: először 30 ének van, ami azonos az 1623-as énekeskönyvben Várfalvi leírta 30 énekkel. A 80. oldaltól az ábécé újrakezdődik, ebben a részben újabb 36 ének és zsoltár található vegyesen.

\section{3. Temetési énekeskönyvek}

Az unitárius temetési énekeskönyvekröl igen keveset tudunk, de annyi bizonyos, hogy a protestáns gyakorlattól eltérően az unitárius halotti énekeskönyvek a gyülekezeti énekeskönyvtől mindig külön nyomtatványban jelentek meg. ${ }^{60}$

Az első fennmaradt halotti énekeskönyv az RMNy 2903, ${ }^{61}$ 1660-ban jelent meg (feltehetően a nagy pestisjárvány miatt kapott kivételes nyomtatási engedély birtokában). Ahogyan azt az RMNy is megjegyzi, ${ }^{62}$ ebből a példányból látszik, hogy az Újfalvi-féle temetési énekeskönyvek átszerkesztett változata. Az átszerkesztés alatt például az ábécérendes szerkesztési elvet, illetve a bővítményeket érthetjük. E kiadás szövegváltozatait összevetve az 1697-es kiadású unitárius temetési énekeskönyvvel ${ }^{63}$ alig találunk különbséget. (Az Újfalvi-féle temetési énekeskönyv anyagával összevetve a variánsokat azonban azt láthatjuk, hogy a gyülekezeti énekek variálódására, változására jellemző tendenciák itt is megfigyelhetőek, de nem olyan mértéküek a változtatások, mint a gyülekezeti énekeknél. Ennek az okát érdemes abban keresni, hogy a temetési énekeket a kántor és az iskolás kórus énekelte, a hívek aktív részvétele nélkül. Talán éppen emiatt nem variálódott annyira, hiszen nem volt kitéve a közösségi éneklés okozta változásoknak.)

Az 1660-as kiadásnak idáig egy példánya volt ismeretes, mely a kolozsvári akadémiai könyvtárban található. Ám nemrégiben árverésen előkerült az elveszett székelykeresztúri

\footnotetext{
${ }^{60}$ Ahogyan arra korábban céloztunk, a többi felekezetnél találunk az énekeskönyvtől külön, illetve azzal együtt nyomtatottakat is. Újfalvi Imre 1602-es református énekeskönyve tartalmazza a temetési énekeket, de külön címlappal, jól elkülönítve a gyülekezeti énekektől.

${ }^{61}$ Az RMNy-en kívül ismerteti: H. HuBERT, i.m., 214.

${ }^{62}$ RMNy 2903. (IV. kötet, 295.)

${ }^{63}$ RMK I. 1504. Ismerteti: H. HUBERT, i.m., 248.
} 
gimnáziumból való példány is. A példányt még az árverés, és az azt követő per előtt ${ }^{64}$ sikerült kézbe venni, így néhány dolgot érdemesnek tartunk megemlíteni róla. A példány Jakab Elek hagyatékából került Székelykeresztúrra a 19. század végén, s a gimnázium pecsétje megtalálható a nyomtatványban is. A példány kiegészítései, kéziratos toldalékai jól mutatják, hogy a korban mekkora igény volt a gyülekezet részéről az énekeskönyvekre. Az 1697-es temetési énekeskönyvröl tudjuk ugyan, hogy 1000 példányban nyomják ki, ${ }^{65}$ ám ez az 1660as kiadás kézzel beírva tartalmazza az 1697-es kiadás bővítményeit is, tehát egy használója szükségesnek tartotta a kiegészítését. Így minden bizonnyal később, a 17. század legvégén, a 18. század elején is használták még, hiszen hozzáigazították az újonnan megjelent, 1697-es kiadáshoz. $^{66}$

Kénosi-Uzoni egyháztörténetében a következő szerepel a halotti énekeskönyvek kiadásáról:

„Ennek a legrégebbi példányából egyet sem láttam, ámbár bizonyos, hogy Heltai-féle betükkel legalábbis háromszor, ha nem többször adták ki. Abrugyi Györgynek két kiadása van, s bennük még egy régebbi kiadásról történik emlités. Az első kiadás címe így hangzik: In exequiis defunctorum canendae. Halott temetéskorra való énekek. Mostan újonnan, szép, ékes és több halotti énekekkel, három karban állatván megjobbíttatott. Kolozsvárban Helthus Gáspár mühelyében nyomtattatott Abrugyi György által. ${ }^{67}$ Az év nincs kitéve. Abrugyi György nyomdamester azonban 1631-1660 között müködött nyomdászként."

Abrugyi véleményünk szerint az 1632-es gyülekezeti énekeskönyv kiadása és a dézsi complanatio közti években is kiadott egy - korábbi változatra épülő - halotti énekeskönyvet. Ha figyelembe vesszük, hogy az 1638-as dézsi complanatio megnehezítette a nyomtatást, és számolunk azzal a ténnyel, hogy az 1660-as kolozsvári pestisjárvány idején kijött egy újabb

64 A könyvlopásról bővebben Farkas Gábor Farkas írt a Nemzeti Könyvtár blogján: http://nemzetikonyvtar.blog.hu/2014/09/26/felmilliorol_indult_volna_a_licit_regi_konyvek_uj_tolvajok_2_resz (Letöltés: 2015. 05. 15.)

${ }^{65}$ Újabban Molnár Lehel és Molnár Dávid talált a Kmitáné-féle nyomda történetéhez új adatokat. Ezeknek egy részét Perger Péter is publikálta. Perger Péter, Egy 17. századi nyomdafelszerelés útja Bécstöl Kolozsvárig = A magyar grafika 5 éve, http://epa.oszk.hu/00800/00892/00033/pdf/11.pdf (Letöltve: 2015. 04. 28). És PERGER Péter, $A$ kolozsvári unitárius egyház nyomdájáról való számvetés $=$ Fata libelli a nyolcvanéves Borsa Gedeon köszöntésére, Budapest, Országos Széchényi Könyvtár, 2003, 289-304. A Molnár Dávid által talált dokumentumok, illetve annak értelmezése kéziratban. MolnÁR Dávid, Kmita Andrásné, a kolozsvári unitárius egyház nyomdájának felállitója. Adalékok a nyomda történetéhez.

${ }^{66}$ Ebböl is látható, hogy az unitárius énekeskönyvek kiadásakor mindig a szükség vezette a kiadót: mire új énekgyüjtemények jelentek meg, a korábbi kiadások már elfogyhattak, megkoptak, hiszen sokkal ritkábban adtak ki unitárius énekeskönyvet a 17. században, mint református vagy evangélikus, vagy egységes protestáns énekgyüjteményt. Emiatt megemlíthetjük azt is, hogy úgy tünik, az unitárius énekeskönyv-kiadásoknál a kereskedelmi szempontok nem játszanak olyan fontos szerepet, mint a többi protestáns felekezetnél.

${ }^{67}$ Ezt a mára nem ismert énekeskönyvet az RMK I. 942/B jelzeten tartjuk számon, az RMNy II. kötete appendixként hivatkozik rá (App. 139). Ismertetése: H. HUBERT, i.m., 213.

${ }^{68}$ KéNOSI TÖZSÉR - UZONI FosZTó, i.m., 813. 
temetési énekeskönyv, - hiszen szükség volt a halotti énekek újrakiadására, már elkoptak az előző kiadások, - akkor nagyon valószínü, hogy az Abrugyi által nyomtatott halotti énekeskönyv az 1630-as években, 1638 előtt keletkezett. ${ }^{69}$ Az RMK I. 942/B jelzetű, az RMNy App. 139. száma alatt „,kellő bizonyiték nélkül feltételezett kiadás" ${ }^{\text {70 }}$ - lévén, hogy láttuk, Abrugyi 1632-ben gyülekezeti énekeskönyvet, majd 1635-ben magánhasználatra szánt énekeskönyvet is nyomtatott - meglétét ezzel a megfontolással is megerősíthetjük. Másfelől talán szükebbre szabhatjuk a megjelenés időkeretét is. Az 1660 előtti dátumot ${ }^{71}$ némileg pontosítja, ha figyelembe vesszük, hogy Abrugyi jóval korábban belekezdett nyomdai munkálatokba, illetve a többi unitárius énekeskönyv megjelenési idejét is számba véve nem feledkezhetünk el a dézsi complanatio következményeiröl. Így ennek a kiadásnak az időpontját érdemes 1631 és 1638 között keresnünk, talán éppen az 1632-35 körüli időszakban.

Mivel a ma már csak leírásból ismert nyomtatvány címe egyértelmúen arra utal, hogy megújított, megjobbított halotti gyűjteményről van szó, így feltételezhetjük, hogy ezt az 1630as években keletkezett kiadást is megelőzte egy másik, melyből nem maradt fenn példány. Ennek minden valószínűség szerint abban az időben kellett megjelennie, amikor az első gyülekezeti és az első magánhasználatra szánt énekeskönyv is megjelent, tehát az 1610-es, 1620-as években.

1697-ben szintén megjelent egy halotti énekeskönyv. Élve azzal, hogy az unitárius nyomda Kmita Andrásné költségével és segítségével felújíttatott, ebben az évtizedben az unitáriusok nyomtattak gyülekezeti énekeskönyvet (1697), halotti énekeskönyvet (1697), és egy magánhasználatra szánt ima-énekeskönyvet is (1700).

Az 1697-es kiadást, (RMK I, 1504) csakúgy, mint a gyülekezeti énekeskönyvet is, Kmita Andrásné költségével nyomtatták ki. A címlapja: ${ }^{72}$ „In exequiis defunctorum canendae. Halot temeteskorra való enekek. Mellyek mostan ujjonnan szép hellyes, és több, Halotti Enekekkel és Sóltárokkal, az Abece rendi szerént, meg jobbittattak, és ki botsáttattak. Kmita Andrasne költségével Kolosvaratt, Az Unitaria Ecclesia Typussival, Liszkai Mihaly által, Anno 1697."

E nyomtatvány mérete szintén tizenkettedrét.

\footnotetext{
${ }^{69}$ Ezt a kiadást KANYARÓ Ferenc ( A legrégibb unitárius énekeskönyvekről, MKSz, 1895, 321-332, főként 330331) 1630 és 1660 közé teszi, de úgy gondolom, hogy a történeti és az irodalomtörténeti adatok tükrébe ezt a kiadást érdemes 1632 - a gyülekezeti énekeskönyv keletkezési ideje - és 1638 - a dézsi complanatio - közé tenni. Mindenképp érdemes azonban figyelembe venni Kanyaró azon észrevételét, hogy a '30-as évek körüli halotti énekeskönyv-kiadás az Újfalvi Imre-féle temetési rendet követi.

${ }^{70}$ RMNy App. 139. (II.kötet, 637.)

${ }^{71}$ H. HubERT, i.m., 213; KÉNOSI TÖZSÉR - UZONI FOSZTÓ, i.m., 696.

${ }^{72}$ H. HUBERT, i.m., 248.
} 
A 17. századi nyomtatott unitárius énekeskönyvek története számos ponton további kérdéseket implikál. Ezek a datálást és a szerkesztők kilétét egyaránt érintik. A feltételezett, vagy nagyon töredékes kiadások pedig újabb és újabb problémákat vetnek fel. Úgy gondoljuk azonban, hogy a néhány kiegészített adat tükrében az elmondható, hogy az unitáriusok igyekeztek a gyülekezeti, a temetés illetve a magánhasználati énekeskönyveket nagyjából egy időben kiadni a század folyamán. A kiadási szokások pedig igen hasonlóak ahhoz, amelyet Újfalvi Imre 1602-es énekeskönyvének előszavában ideálisnak tartott, s a kiadási időpontokból is látható, hogy - ellentétben a református és az evangélikus kiadások megjelenésével - az unitárius énekeskönyvek kiadását nem kereskedelmi szempont, hanem a hiányból, az elkopásból fakadó szükség implikálta. A protestáns gyüjteményekhez képest azt is elörevetíthetjük, hogy az unitárius gyüjteményekben minden esetben jól tetten érhető a szerkesztő változtatása, amely szinte minden esetben arra utal, hogy az unitárius kiadásoknál kellett, hogy legyen egy „felsőbb,” talán valamely egyházi vezető általi jóváhagyás is a megjelenés előtt.

\section{A szövegösszevetések alapjául szolgáló nyomtatott és kéziratos források ismertetése}

Jelen fejezetben röviden ismertetni szeretnénk azokat a nyomtatványokat és kéziratokat, amelyek a 16. században, a 17. század elején keletkeztek, és nagyobb számú énekegyezést mutatnak az 1602-15 közötti kolozsvári unitárius énekeskönyv énekanyagával. $^{73}$ A szövegváltozatok összevetéseit ugyanis ezeknek a forrásoknak a segítségével készítettük el. Noha a legtöbb esetben csupán apró kiegészítéseket tehetünk az RMNy vagy az RMK, Stoll, illetve H. Hubert Gabriella oldalain olvasható leírásokhoz, fontosnak gondoltuk, hogy a dolgozat a fenti összefüggésben szereplő forrásokról áttekintést adjon.

\footnotetext{
${ }^{73}$ Terjedelmi okok miatt a fejezetben nem tárgyaljuk azokat a forrásokat, amelyek csupán egy-két énekegyezést mutatnak a vizsgált anyaggal. Ilyen nyomtatvány például az RMNy 962 (SzENCI MoLNÁR Albert, Psalterium Ungaricum, 1607. Herborn) és az RMNy 1037 (SzENCI MolnÁR Albert, Szent Biblia a ... 1612, Oppenheim - a vegyes énekrész) vagy az RMNy 1599 (Balassi Bálintnak Istenes... 1633. Bécs), illetve a kéziratos források közül pl. a Balassa-kódex.
} 


\section{1. A nyomtatványok rövid leírása}

A következőkben sorra vesszük a szövegösszevetések alapjait képező nyomtatványokban megjelent és kéziratos énekgyüjteményeket, s igyekszünk ezekről a szakirodalom és a facsimilék, illetve az eredeti anyagok alapján leíró jellegü ismertetést adni. Noha apró kiegészítéseket csak a kéziratos énekgyüjteményeknél tesz a dolgozat, a gyűjtemények ismertetését, leírását a későbbi gyakori hivatkozások miatt a könnyebb olvashatóság érdekében kíséreljük meg.

A későbbi fejezetekben tárgyalt szövegösszevetések során - ugyanúgy, mint a szerkezeti hasonlóságok és az incipit listák összehasonlítása során is - az alábbi nyomtatványok variánsait vetettem össze az RMNy 983-mal, az 1602-15 közötti unitárius énekeskönyvvel. ${ }^{74}$

\section{RMNy 160 - 1560-61, Óvár, Kassa, Debrecen: A keresztyéni gyülekezetben való isteni dicséretek, kiadója és szerkesztője Huszár Gál, protestáns ${ }^{75}$}

A kiadást az óvári prédikátor Kassáról Debrecenbe menekülve adja ki, s mint azt az ajánlásból megtudjuk, a menekülő Huszár Gált nyomdájával együtt Melius Juhász Péter fogadja be. A nyomtatvány 105 gyülekezeti éneket tartalmaz, ebből 49 ének kottával ellátott. Nótajelzés-használata is következetesnek mondható, mindössze 11 éneknél nincs kotta vagy nótajelzés. Az RMNy 983-mal (1602-15, Kolozsvár, unitárius) a 105 énekéből 34 közös. Ahogyan az említett szakirodalomban olvasható, Huszár Gál a prédikáció-központú istentiszteletnek megfelelően szerkesztette énekeskönyvét:

1. prédikáció elötti, a Szentlélek ajándékáért való könyörgések

2. prédikáció utáni énekek

3. istentisztelet előtti hálaadások és könyörgések

4. temetési énekek

5. ünnepi énekek

${ }^{74}$ Az unitárius nyomtatványokról az előző fejezetben szóltunk.

${ }^{75}$ RMNy 160. (I. kötet, 190-191), H. HUBERT, i.m., 110-113. Az összevetéseket a facsimile kiadás alapján készítettem: Huszár Gál énekeskönyve, 1560-61, szöveggondozás VARJAS Béla, kísérő tanulmány BORSA Gedeon, Bp., 1983 (Bibliotheca Hungarica Antiqua, XII). Az énekeskönyvre, annak variánsaira a továbbiakban a rövidség kedvéért az 1560-as óvári kiadásként hivatkozunk. 
6. zsoltárok

7. úrvacsora-ének $(1 \mathrm{db}){ }^{76}$

RMNy 222 - 1566, Várad, A keresztyéni gyülekezetben való isteni dicséretek, kiadó/nyomdász: Raphael Hoffhalter, szerkesztő: L. F., akinek kiléte még nem tisztázott, protestáns ${ }^{77}$

Az énekeskönyv 117 énekéből 90 megegyezik az 1560-as óvári kiadás anyagával, bár a szövegváltozataik tartalmaznak eltéréseket egymáshoz képest. Az RMNy 983 -mal 39 éneke közös, ebből egy ének duplán található meg ebben a gyüjteményben. Szerkezete a következő:

1. prédikáció utáni énekek

2. káté-énekek

3. zsoltárok

4. halotti énekek ( $2 \mathrm{db})$

5. vegyes énekek rendezetlenül

6. ünnepi énekek

7. vegyes énekek. ${ }^{78}$

RMNy 264 - 1569, Debrecen, Énekeskönyv, melyböl szoktanak dicséretet mondani az anyaszentegyházban és keresztyéneknek minden gyülekezetiben... Szegedi Gergely szerkeszti, Komlós András nyomtatja, református ${ }^{79}$

Ezzel a nyomtatvánnyal jött létre az ún. debreceni énekeskönyv-típus, amelynek számos kiadása lesz a 16-17. század folyamán.

${ }^{76}$ H. HUBERT, i.m., 111.

77 RMNy 222, (I. kötet, 249-250), H. HUBERT, i.m.,115-116. Az összevetések a facsimile kiadás alapján készültek: A keresztyéni gyülekezetben való isteni dicséretek, Várad, 1566, szöveggondozás VARJAS Béla, kísérő tanulmány ScHUlEK Tibor, Bp., Akadémiai, 1975 (Bibliotheca Hungarica Antiqua IX). A továbbiakban az 1566os váradi kiadásként idézzük.

${ }^{78}$ H. HUBERT, i.m., 116.

${ }^{79}$ RMNy 264. (I. kötet 286-288), H. Hubert, i.m., 116-119. Álfacsimile kiadása: SzILÁDY Áron, Énekes könyv... Bp., 1893. Az összevetések az álhasonmás-kiadás és Pap Balázs fotómásolatai alapján készültek. A továbbiakban az 1569-es debreceni énekeskönyvként hivatkozunk rá. 
Szerkezete a következő: 1. zsoltárok; 2. ünnepi énekek; 3. úrvacsora-énekek; 4. prédikáció utániak; 5. szentegyházbeliek; 6. közönséges isteni dicséretek. A zsoltárok szám szerint növekvő sorrendben követik egymást. 136 ének található az énekeskönyvben, ebből 97 azonos az 1560-as óvári kiadáséval, ${ }^{80}$ ám megfigyelhető, hogy szövegváltozatai igen gyakran eltérnek azétól. Az unitárius énekeskönyv 118 vizsgált énekéből 41 található meg a kiadásban.

A debreceni énekeskönyvek gyülekezeti énekeinek szövegváltozatai mutatják egymáshoz képest a legkisebb variabilitást. Míg az evangélikus énekeskönyvekben található gyülekezeti énekek szövegváltozatai az egyes kiadásokban olykor igen eltérnek egymástól, addig a debreceni típusú énekgyüjtemények variánsai a legtöbb esetben legfeljebb ritmus vagy rímjavításokat, apróbb nyelvjárási változásokat mutatnak csupán egymáshoz képest. Ám az mindenképp hangsúlyozandó, hogy az eltérések csekély volta ellenére nem mondhatjuk, hogy a debreceni énekeskönyv-kiadások egymással teljesen megegyező szövegváltozatokat közölnek. A későbbiekben lesz szó például a kolofonok, a címek változásáról, amelyek tendenciózusnak mondhatók. Az unitárius gyülekezeti énekeskönyvek - noha nyomatékosan hangsúlyoznunk kell, hogy a legeltérőbb szövegváltozatokkal rendelkeznek a többi felekezethez képest, - abban az értelemben rokoníthatók a debreceni énekeskönyv-típus kiadási sajátosságaival, hogy ugyanúgy kevés változás van az egyes kiadások szövegei között. Míg a debreceni kiadásokban ezek legfőképp a rím és/vagy ritmusjavításokban, néhány szó megváltoztatásában, kicserélésében nyilvánulnak meg, addig az unitárius énekeskönyvek korpuszán belüli változások (a rím- és ritmusjavításon túl) föleg a szövegek dogmatikáját érintik.

RMNy 276 - 1570, Debrecen, címlap hiányzik, cím nem ismert, a nyomdász Komlós András, református ${ }^{81}$

Az 1569-es debreceni református énekeskönyv újrakiadása, csak csonka példányt ismerünk belőle. A szerkezete azonos az 1569-es kiadáséval, ám a szövegváltozatokban több

\footnotetext{
${ }^{80}$ Az eddigieket bővebben kifejti: H. HUBERT, i.m., 117.

${ }^{81}$ Leírása: RMNy 276. (I. kötet, 297-98), H. HUBERT, i.m., 119-120. A szövegösszevetéseket a Pap Balázstól kapott fotómásolatok alapján készítettem el, köszönet érte. A nyomtatványra a továbbiakban az 1570-es debreceni énekeskönyvként hivatkozunk.
} 
apró eltérést is találunk, melyek elsősorban a sajtóhibák, a rímre, ritmusra, szótagszámjavításra vonatkoznak, de a későbbi fejezetekben találkozunk olyan példákkal is, ahol az 1569-es debreceni kiadáshoz képest egy-egy gyülekezeti ének eltérő szöveggel jelenik meg. 101 éneke maradt fenn, a csonkasága miatt így kevesebb közös ének található meg az unitárius kiadásokkal: mára 34 unitárius gyülekezeti éneket vethetünk össze ezzel a nyomtatvánnyal.

\section{RMNy 353 I./II. - 1574 Komjáti, A keresztyéni gyülekezetben való isteni dicséretek és imádságok, kiadja és szerkeszti Huszár Gál, evangélikus énekeskönyv ${ }^{82}$}

A kiadás jóval bővebb az első, 1560-as óvári Huszár Gál által szerkesztett énekeskönyvnél. Hubert Gabriella részletes ismertetéseiböl a témánk szempontjából a szerkezetet emelnénk ki: az I. kötet 1. része káté-énekeket tartalmaz, 2. része invokációkat, 3. része ünnepi énekeket, 4. részében a prédikáció utáni énekek találhatók. A II. kötetben folytatódik a prédikáció utáni énekrész, majd 5. részként a zsoltárok következnek, 6. részként a szentegyházba való isteni dicséretek, majd végül a 7. részben a temetési énekek találhatók meg. 191 ének van a nyomtatványban, amelyből az összehasonlítás során 49 közös éneket találtunk az általunk vizsgált anyaggal. Noha a kiadás tartalmaz kottákat, Huszár Gál olyan kottát nem közöl ismét, amely az 1560-as óvári kiadásában már megjelent. Hubert Gabriella hangsúlyozza, hogy az énekeskönyv utóéletét a 16. századi magyar evangélikus énekeskönyvekben követhetjük nyomon, s itt az RMNy 513-at (1582, Detrekő) és az RMNy 713-at (1593, Bártfa) említi. ${ }^{83}$ A szerkezeti, énekbeli azonosságát tekintve valóban markánsan látható a hasonlóság az említett evangélikus kiadásokban. A szövegösszevetések során kimutatható érdekes eredmény azonban, hogy az 1582-es detrekői kiadás szövegváltozatai valóban a legtöbb esetben az 1574-es komjáti kiadással rokoníthatók a saját eltérések ellenére is, ám az 1593-as bártfai kiadás vizsgált szövegváltozatai sok esetben nem csupán az evangélikus vonallal mutatnak hasonlóságot, hanem az 1590-es debreceni kiadás szövegváltozataival is.

\footnotetext{
${ }^{82}$ RMNy 353. (I. kötet, 356-359), H. HuBERT, i.m., 120-125. Facsimile kiadása: HuszÁR Gál, A keresztyéni gyülekezetben való isteni dicséretek és imádságok, Komjáti, 1574, közzéteszi KöSzEGHY Péter, kísérő tanulmány HuBERT Gabriella, Bp., MTA ITI, 1986 (BHA XIII). A szövegösszevetéseket a facsimile alapján készítettük el. A nyomtatványra a továbbiakban az 1574-es komjáti kiadásként hivatkozunk.

${ }^{83}$ H. HuBERT, i.m., 125.
} 


\section{RMNy 429 - 1579, Debrecen, Énekeskönyv, melyböl szoktanak... kiadó Hoffhalter Rudolf, Gönci György szerk.?, református énekeskönyv ${ }^{84}$}

A korábbi debreceni kiadások bővített, javított változata. Néhány eltérés a variánsokban is megfigyelhető, de a korábbi kiadásokkal zömében azonosak a szövegek. Szerkezete: 1. zsoltárok; 2. ünnepi énekek; 3. úrvacsora-énekek; 4. szentegyházbeliek; 5. közönséges isteni dicséretek. 119 ének található a kötetben, ebböl 11 ének új az 1569-es kiadáshoz képest, s Hubert Gabriella megállapítása szerint a 11 énekből 7 itt jelent meg először nyomtatásban. Szegedi Gergely énekeskönyvében volt 28 olyan ének, amely ebben már nem található meg. ${ }^{85}$ Az unitárius énekeskönyv 118 vizsgált énekéből 39 található meg a nyomtatványban.

\section{RMNy 513 - 1582, Detrekő, Énekek három rendbe, kiadója és szerkesztője Bornemisza Péter, evangélikus ${ }^{86}$}

Az első olyan magyar nyelvü evangélikus énekeskönyv, mely a gyülekezeti használaton túl magánhasználatra szánt énekeket is tartalmaz. Három része alapvetően három különböző célt szolgál: 1. gyülekezeti énekeskönyv; 2. prédikációs énekek; 3. bibliai históriák. ${ }^{87}$ Hubert Gabriella 198 énekverset számol, ebből a 118 unitárius énekkel 60 ének egyezik, s ebből a 60 egyezésből egy ének a nyomtatványban kétszer is megtalálható, két variánsban. Bornemisza énekeskönyve, amint már említettük, rokonítható Huszár Gál 1574-es komjáti kiadásával, s a szövegváltozatok között is nagy hasonlóságot találunk. Az 1593-as bártfai énekeskönyv némely éneke egyértelműen ezzel a hagyományággal rokonítható

\footnotetext{
${ }^{84}$ RMNy 429. (I. kötet, 412-414), H. HuBERT, i.m., 126-128. A fotómásolatokért, melyből az összevetések készültek, Pap Balázsnak tartozom köszönettel. Az énekeskönyvet a továbbiakban az 1579-es debreceni énekeskönyvként hivatkozzuk.

${ }^{85}$ H. HubERT, i.m., 127.

${ }^{86}$ RMNy 513. (I. kötet, 468-72), H. HuBERT, i.m., 129-132. Hasonmás kiadása, melyből az összevetések készültek: BoRNEMISZA Péter, Énekek három rendben, Detrekő, 1582, kísérő tanulmány KovÁCs Sándor Iván, szöveggondozás VARJAS Béla, Bp., 1964 (BHA VI).

87 A három „rend” funkcióiról, retorikai jellemzőiröl bővebben: OLÁH Szabolcs, Hitélmény és tanközlés, Bornemisza Péter gyülekezeti énekhasználata, Debrecen, Csokonai Universitas Könyvtár, Kossuth Egyetemi Kiadó, 2000 (Bibliotheca Studiorum Litterarium 22).
} 
variánssal rendelkezik, ám a bártfai énekeskönyv jelentős szövegváltozásokat mutat, mely az 1590-es debreceni kiadással is rokonítja azt.

RMNy 640 - 1590, Debrecen, címlap nincs, Gönci György szerkeszti, kiadja Csáktornyai János, református ${ }^{88}$

A debreceni kiadások közül először e kötetben jelenik meg a nyomtatvány végén egy temetési énekeket tartalmazó rész, mely az 1602-es kiadás után bevett szokássá válik a debreceni-típus esetében. Szerkezete: 1. zsoltárok; 2. ünnepi énekek; 3. úrvacsora-énekek; 4. szentegyházi dicséretek; 5. temetési énekek. 190 ének található a kötetben, s az 1569-es debreceni kiadásból 11 ének nem kerül bele. 17 ének itt jelenik meg elöször nyomtatásban. Ahogyan azt már Szilády Áron is megjegyzi az 1569-es énekeskönyv álfacsimile-kiadásához írott előszavában, ${ }^{89}$ az 1582-es detrekői kiadással is rokonságban áll ez a nyomtatvány, nemcsak az öt megelőző debreceni református énekeskönyvekkel. Szövegváltozatait nézve több esetben is rokonítható a Bornemisza-féle énekgyüjtemény variánsaival, s érdekes módon e debreceni énekeskönyv variánsai majd ugyanígy hatással lesznek az 1593-as bártfai evangélikus kiadás szövegváltozataira. Az idáig, 1590-ig megjelent debreceni-típusú énekeskönyvek szövegváltozatai közül ezek a legeltéröbbek. A 118 vizsgált unitárius ének közül 58 ebben a kiadásban is megjelent.

RMNy 713 - 1593, Bártfa, A keresztyéni gyülekezetben való isteni dicséretek... kiadója David Gutgesell, szerkesztője ismeretlen, evangélikus kiadás ${ }^{90}$

H. Hubert Gabriella rámutat arra, hogy a nyomtatvány szerkezetével rokon kiadások Németországban jelentek meg. A kötet három része ugyanis a következö: vannak ünnepi énekek, amelyeket az ünneptelen félév énekei követnek Szentháromság-nap utáni közönséges

\footnotetext{
${ }^{88}$ RMNy 640. (I. kötet, 557-560), H. HUBERT, i.m., 133-134. Az összevetés alapjául szolgáló fotómásolatért köszönettel tartozom Pap Balázsnak. Az énekeskönyvre a továbbiakban az 1590-es debreceni kiadásként hivatkozunk.

${ }^{89}$ SZILÁDY Áron, i.m., XV.

90 RMNy 713. (I. kötet, 606-609), H. HUBERT i.m. 136-140. A kötetet a továbbiakban 1593-as bártfai énekeskönyvként hivatkozzuk.
} 
isteni dicséretek címmel, s végül temetési énekek következnek. ${ }^{91}$ A nyomtatvány 267 gyülekezeti éneket tartalmaz, s a vizsgált unitárius anyaggal a legtöbb egyezés itt figyelhető meg: 67 közös éneket találunk, s ebből 2 ének az 1593-as bártfai kiadásban kétszer, két külön variánsban jelenik meg. Fontos azonban megemlíteni, hogy az unitárius nyomtatvánnyal a nagyszámú énekegyezés ellenére nem állnak a variánsok közvetlen kapcsolatban: az unitárius korpusz változatok tekintetében jól elkülönül a többi protestáns énekgyüjtemény variánsaitól, s számos különbséget tartalmaz. Ennek ellenére természetesen vannak olyan esetek, amikor a többi protestáns variánstól eltérő 1593-as bártfai variáns és az unitárius kiadásban szereplö egy-egy énekvariáns azonos eltéréseket tartalmaz, de minden ilyen esetben találkozunk saját eltérésekkel is. Az 1593-as énekeskönyvön jól látszik, hogy a nyomtatás közreműködője (kérdés, hogy ez a nyomdász, a szerkesztő, vagy a szedő) nem tudott jól magyarul. Sok olyan félreértés, félreszedés van, amely a nyelvtudás hiányának tudható be. A következő, 1602-14 között Bártfán megjelent evangélikus énekeskönyv az ilyen nyelvi jellegü hibák többségét javítja, ám bővelkedni fog az újabb, másutt megjelenő nyelvi tévesztésekben is.

\section{RMNy 886 - 1602, Debrecen, Keresztyéni énekek, Újfalvi Imre szerkeszti, Rheda Pál adja ki, református $^{92}$}

Újfalvi Imre énekeskönyvének részletező ismertetésétől kénytelenek vagyunk eltekinteni, ám fontos megjegyezni, hogy megújított énekgyüjteménye a 17. század folyamán számos új kiadást ér meg, noha Újfalvi nevét a református egyházi emlékezet eltávolítja a későbbi nyomtatványokból. Újfalvi Imre azon túl, hogy megújított énekeskönyv kiadására vállalkozik, olyan részletes előszót ír a nyomtatványhoz, amely az addigi énekeskönyvkiadások ismertetését, az általa ideálisnak tartott kiadás elméletét is tartalmazza. Ezen kívül műfaji, használatbeli megfontolásokat, leírásokat ad a 16. század népszerü irodalmi szövegeihez. Az előszóban általa ideálisnak tartott kiadást ő maga sem tudja megteremteni, mindenesetre előszava egyedülálló tudásról, filológiai munkálkodásról tanúskodik.

Az énekeskönyv első része a gyülekezeti énekeskönyv, amely a következő szerkezettel rendelkezik: 1. zsoltárok; 2. ünnepi énekek; 3. káté-énekek; 4. különfélék.

\footnotetext{
${ }^{91}$ H. HUBERT, i.m., 139.

${ }^{92}$ RMNy 886. (II. kötet, 35-39), H. HuBERT, i.m., 141-150. A szövegösszevetéseket a facsimile kiadás alapján készítettük: ÚJfalvi Imre, Keresztyéni énekek, 1602, Debrecen, kísérő tanulmány Ács Pál, Bp., Balassi, 2004 (BHA 38). A nyomtatványra a továbbiakban az 1602-es debreceni kiadásként hivatkozunk.
} 
A második része halotti énekeskönyv, amely valószínüleg az 1598-ban szintén Újfalvi által kiadott temetési énekeskönyv bővített változata lehetett. (RMNy 832, példány nem maradt fönn.) A temetési énekek csoportosítását Újfalvi elsősorban a praktikum, a használat alapján végezte el: elöl a halott felvétele előtt mondandó énekek találhatók, melyet a halott kivitelekor mondandók követik, s végül a sír felett énekelt szövegek találhatók a nyomtatványban.

Az énekeskönyv kb. 200 gyülekezeti éneket tartalmaz, melyből 59 megvan az általunk vizsgált 118 ének között is, mi több, vannak olyan énekek, amelyek nyomtatott forrásban az RMNy 983 megjelenése elött csak itt találhatók meg. Ezek az Ilyen fogadást tőn szent Dávid... (RPHA 573); ${ }^{93}$ Bogáti Fazakas Miklós Mely hatalmas a mi urunk... kezdetű éneke (RPHA 867) és a Mostan, Úristen hozzád kiáltunk... kezdetűek (RPHA 1019).

A korábbi debreceni kiadáshoz képest Újfalvi énekeskönyve 48 új éneket vesz be, ám 20 éneket kihagy elödjéből. ${ }^{94}$

A halotti énekek kapcsán annyit érdemes megjegyezni, hogy az unitárius temetési énekeskönyvek anyaga - az első, ma is kézbe vehető példány, az 1660-as temetési kiadás alapján - alapvetően az Újfalvi-féle temetési énekeskönyvekével rokon, annak átszerkesztett (ábécérendes) és bővített változata. Az unitárius temetési énekek szövegei érdekes módon sokkal kevesebb változást mutatnak a református temetési kiadások szövegeihez képest, mint a gyülekezeti énekek általában. Ennek az okát - ahogyan azt már említettük, - talán abban kereshetjük, hogy a temetési énekeket alapvetően a diákságból álló kórus énekelte, így ezek a szövegek nem voltak kitéve olyan változásnak, amelyet az egész gyülekezet általi éneklés, a másolások, a szóbeli terjedés okozott a gyülekezeti énekek esetében. A temetési énekek tehát sokkal inkább a nyomtatás által rögzített formában maradtak meg, s az előadásuk módja is erősen kötötte őket a kollégiumok és az iskolák kisebb közösségéhez. Ezzel magyarázhatjuk talán, hogy a temetési énekeknek alig vannak erőteljes variánsai - leszámítva persze a dogmatikai jellegű eltéréseket. ${ }^{95}$

Újfalvi gyülekezeti énekeskönyve a korábbi debreceni kiadásokhoz képest igen gyakran eltérő szövegváltozatot közöl. A szövegváltozások egy jelentős része a kolofonokat, záró strófákat érinti: jellemzően elhagyja a referenciális strófákat, vagyis igyekszik a szerzővel, szereztetés helyével, idejével megjelölt szövegeket úgy a gyülekezet elé tárni, hogy

\footnotetext{
${ }^{93}$ Ez az ének Újfalvi kötetének 55. lapján található, s az egyetlen példány itt pont csonkult, így sajnos az összevetést nem tudjuk elvégezni, csak a későbbi debreceni kiadások alapján.

${ }^{94}$ H. HUBERT, i.m., 145. Az incipitek ismertetését is tartalmazza.

${ }^{95}$ A dolgozat előmunkálatai során az unitárius temetési énekek is átírásra kerültek, s azok össze lettek vetve az Újfalvi-féle temetési énekek variánsaival. E néhány észrevétel az összevetés alapján készülhetett el, az átírás közlése azonban meghaladja a dolgozat kereteit.
} 
azok olyan záró strófát tartalmazzanak, amelyek már nem a szereztetésre utalnak, hanem a gyülekezet épülését szolgálják: vagy az ének tartalmát, tanítását összegzik, vagy hálaadó, dicsérő formulákat tartalmaznak.

A későbbi debreceni református énekeskönyv-kiadásokról Hubert Gabriella megállapítja, hogy „az 1635-ig megjelenö debreceni énekeskönyvek valójában az ún. debreceni típus Újfalvi-féle átdolgozásának tekinthetők." ${ }^{96}$ Ebből az Újfalvi-féle debreceni típusból idáig úgy tudtuk, hogy az 1616-os kiadás ${ }^{97}$ követi először az 1602-es kiadást. Nemrégiben kiderült azonban, hogy az 1602-es énekeskönyv első újrakiadása - az egyházpolitikai okokból ekkor már kegyvesztett Újfalvi Imre előszavának és nevének mellőzésével, néhány változtatással - 1610-ben jelent meg Debrecenben. Szalai Béla hamarosan megjelenő tanulmánya ${ }^{98}$ ismerteti az eddig ismeretlen nyomtatványt, s a szerző ígérete szerint a kötet tulajdonosának köszönhetően hamarosan digitális másolatban tanulmányozható lesz a kötet. Ezek alapján úgy tűnik, hogy még bőven Újfalvi Imre életében megjelentették az általa kiadott énekeskönyvet némiképp megváltoztatott formában.

\section{RMNy 965 - 1602-14 Bártfa, címlap hiányzik, kiadója Jakob Klöss, szerkesztője ismeretlen, evangélikus ${ }^{99}$}

A nyomtatvány jórészt az 1593-as bártfai kiadást rendezi új szerkezeti egységekbe, 250 énekéből 246 már az 1593-as kiadásban is megvolt, 4 új bővítmény pedig itt jelenik meg először. Szerkezete a következő: ${ }^{100} 1$. ünnepi énekek; 2. isteni dicséretek; (a penitenciáról, a megigazulásról, az úrvacsoráról, az Istenben való hitbéli bizodalomról); 3. hálaadó dicséretek; 4. háborúságban külső ellenségek ellen valók; 5. mikor az ördög és a bün háborgat; 6. az anyaszentegyházról; 7. a jámbor keresztyéni életről; 8. az emberi élet rövid és bizonytalan voltáról; 9. temetési énekek.

Szerkezete olyan, amely elötte egyetlen magyar nyelvü énekeskönyvben sem figyelhető meg. Hubert Gabriella megállapítása szerint a tematikus szerkesztés a német

\footnotetext{
${ }^{96}$ H. HuBERT, i.m., 146.

${ }^{97}$ RMNy 1107.

98 SzALAI Béla, Egy könyvészetileg ismeretlen debreceni református énekeskönyv 1610-böl, kéziratban. Köszönettel tartozom Ács Pálnak, aki felhívta a figyelmemet erre az új adatra.

${ }^{99}$ RMNy 965. (II. kötet, 98-101), H. HuBERT, i.m., 150-52. Az összevetéseket az OSZK-ban található egyetlen csonka példány alapján végeztük el. A továbbiakban a kötetre az 1602-14 közötti bártfai énekeskönyvre hivatkozunk.

${ }^{100}$ A szerkezetet itt is, ahogyan eddig is H. HUBERT Gabriella alapján közlöm. (I.m., 150-151.)
} 
evangélikus énekeskönyvekkel rokonítja. Ahogyan azt említettük, az 1593-as bártfai énekeskönyvhöz hasonlóan ez a gyüjtemény is tartalmaz olyan szöveghibákat, amelyek a nyelvi kompetencia hiányának tudhatók be. A vizsgált unitárius énekekkel 61 közös ének található a kötetben, melyből egy ének duplán szerepel a bártfai kiadásban. Az unitárius énekeskönyv énekeivel néhol azonos eltérések figyelhetők meg a szövegváltozatokban. Ennek az okát feltehetően nem abban érdemes keresni, hogy közvetlen bedolgozták egyik gyüjteményt a másikba, hiszen nem erről van szó, hanem arról, hogy keletkezési időben a vizsgált nyomtatványok közül ezek állnak egymáshoz a legközelebb. Az RMNy a bártfai kötet megjelenésének évét megkíséreli 1609-ben megállapítani, ${ }^{101}$ ekkor jelent meg ugyanis Mihálykó János imádságoskönyve, (RMNy 976) amely két másik alkalommal szintén az énekeskönyvvel egy időben látta meg a napvilágot.

Ha általánosítani próbálunk az elvégzett kutatás alapján, - melyhez nyilván még 118 gyülekezeti ének összehasonlító vizsgálata is kevésnek bizonyul - azt mondhatjuk, hogy a protestáns énekeskönyvek közül egyértelmüen az unitárius énekeskönyvek tartalmazzák a többitől leginkább eltérő szövegváltozatokat, de ha rangsort állítanánk, az 1602-14 közötti bártfai kiadás lenne az unitáriusok után a legmarkánsabb ilyen eltérő változatokat tartalmazó nyomtatvány a többihez képest. Ezt a későbbi fejezetekben részletezzük.

\section{2. A kéziratos források ismertetése}

Az RMNy 983-ban megtalálható gyülekezeti énekek szövegváltozatai a vizsgált korszakból az alább ismertetett kéziratos forrásokban voltak még fellelhetők.

\section{Toroczkai Máté graduálja, 1601 körül, S $1005^{102}$}

Ahogyan azt a dolgozatban már korábban említettük, a graduál mára elveszett, annak tartalmát az unitárius egyháztörténetből ismerjük. ${ }^{103}$ Ez alapján úgy tűnik, hogy a graduál-rész

\footnotetext{
${ }^{101}$ RMNy 965. (II. kötet, 101.)

${ }^{102}$ Stoll Béla, A magyar kéziratos énekeskönyvek és versgyüjtemények bibliográfiája (1542-1840), Bp., Balassi, 2. kiad., 2002, 412-13.
} 
azonos lehetett az első nyomtatott gyülekezeti énekeskönyvével (RMNy 983), és az invokációk után 22 dicséret is megtalálható volt. Mint a korábbiakban erre is kitértünk, egy díszes és nagy költségekkel járó graduál elkészítése, melynek a végén gyülekezeti énekek is találhatók, inkább tünik hiánypótlásnak, mintsem egy meglévő énekeskönyv költséges másolásának, vagy egy hamarosan elkészülő énekgyüjtemény közvetlen előkészítő müveletének, persze ez utóbbi nem zárható ki. A dolgozatban a graduálról a továbbiakban nem esik szó, hiszen a szövegek összevetésére nincs mód.

Detsi-kódex, 1609-1613között, S $25^{104}$

Stoll Béla leírásából tudjuk, hogy a kódex 1609 és 1613 között íródott, föként 16. századi protestáns zsoltárparafrázisokat, gyülekezeti énekeket, históriákat tartalmaz. A szövegek többségének összeírója Detsi István, de nem kizárt, hogy az elején található zsoltárok egy részét más kéz írja. ${ }^{105}$ (A dolgozatban vizsgált énekek közül 8 található meg a forrásban, és a variánsok jórészt itt, az elején található zsoltárrészben vannak.)

Az ebben a forrásban is megtalálható 8 ének az 1590-es, illetve az 1602-es debreceni kiadásokkal mutat rokonságot, ám saját eltéréseket szinte minden esetben tartalmaz. Mindenesetre látszik az 1590 utáni református énekhagyomány ismerete a szövegvariánsokon, de a rögzültebb nyomtatott hagyománynál több eltérést, nagyobb variabilitást tapasztalunk a változatokban. Az 1602-es debreceni énekeskönyv-kiadás mellett itt szerepel igen korán Rimay-szöveg is, $A$ jó hitü ember... kezdetü (RPHA 14). Benne van Balassi Ó, én kegyelmes Istenem... kezdetü énekének (RPHA 1109) átköltése is.

Bölöni-kódex, 1615-21 között, S 30 ${ }^{106}$

\footnotetext{
103 KÉNOSI TŐZSÉR - UZONI FOSZTÓ, i.m., 797-801.

${ }^{104}$ STOLL, i.m., 35-36. Az énekeket fotómásolat alapján vetettem össze a többi protestáns szövegváltozattal. A fotókért köszönettel tartozom Pap Balázsnak, aki saját digitalizált másolatait a rendelkezésemre bocsátotta.

105 Stoll, i.m., 35-36. Ezen kívül DÉZSI Lajos ismertetése: Régi magyar verseskönyveink ismertetése, VII, A Detsi-kódex, ItK, 1927, 68-76.

${ }^{106}$ STOLL, i.m. 38-39. Az 1602-15 közötti énekeskönyvvel 43 közös éneket tartalmaz. A szövegösszevetéseket az OSZK Oct. Hung. 642. alapján készítettem. Ír róla az RMKT unitárius kötet is: RMKT 17/4. 534-536.
} 
A Háromszéken, Bölönben és Székelykeresztúron keletkezett unitárius kódex másolóiról, datálásáról és kilétéről a dolgozat írása közben új adatokat sikerült megismerni. ${ }^{107}$ Az újabb kutatások alapján azt mondhatjuk, hogy a másolói nagy valószínűséggel Köpeczi György és Bölöni Zsigmond János voltak, és az énekek többsége megtalálható a nyomtatott unitárius hagyományban is. Az 1602-15 közötti unitárius gyülekezeti énekeskönyvvel összevetve a Bölöni-kódex variánsait azonban nagyszámú eltérést tapasztaltunk. Az eltérések egyrészt a dogmatikát érintik: a KG monogramot viselő (véleményünk szerint Köpeczi Györgyöt takaró) másoló 1619 -ig, a Keserüi Dajka-féle vizitációig ír a kódexbe, ${ }^{108}$ s a legtöbb esetben tisztán adorantista, olykor még a református dogmatikának is teljes mértékben megfelelö, dogmatikailag „enyhe” szövegváltozatokat hoz, amelyek a legtöbb esetben eltérnek a nyomtatott hagyománytól. 1619-től a BJS monogramot viselő személy ír a kódexbe Székelykeresztúron, (szerintünk Bölöni Zsigmond János), aki az előző kéz által bemásolt szövegeket is radikalizálja, nonadorantistává változtatja, illetve 1619 után már csak ilyen, következetesen nonadorantista szöveg kerül a kódexbe. Ezek oka elsősorban egyháztörténeti jellegü, ennek részletes ismertetésétől itt eltekintünk, ${ }^{109}$ csak vázlatosan említjük meg a lehetséges okokat. A hivatkozott tanulmányokból kiderül, hogy a történeti dokumentumok, például a Keserüi Dajka-féle peranyag vallomásai alapján az látható, hogy 1619-ig, Keserüi Dajka János erélyes fellépéséig Háromszéken a református és az unitárius egyház nem volt szorosan elkülönülve egymástól, mi több, az istentiszteleteket is közösen tartották. Ha egy faluban unitárius volt a lelkész, a tanító református volt, vagy éppen fordítva. 1619 után a helyzet megváltozik, mert az erőszakos áttérítések megkezdődnek, s emiatt a felekezetek élesen elkülönülnek egymástól. Ez a Bölöni-kódex szövegeiben is megfigyelhető: ahogyan említettük, 1619-ig szinte minden szöveg adorantista, a reformátusok számára is teljesen elfogadható hitelveket tartalmaz. 1619-től a másoló radikálisabb szövegeket ír be, így a kódex minden bizonnyal unitárius kézben maradt.

A nem dogmatikai jellegű szövegváltozásokról elmondhatjuk, hogy egy része minden bizonnyal abból fakad, hogy Háromszéken nem volt megfelelő számban elterjedt gyülekezeti énekeskönyv a hívek kezében, így feltehetően kéziratokból, esetleg emlékezetből énekeltek. Valószínű, hogy a kódex lejegyzője sem egy nyomtatott vagy kéziratos énekgyüjteményt

${ }^{107}$ Ezek hosszas ismertetésétől terjedelmi okokból eltekintünk. Bővebben: HEvESI Andrea, Adalékok a Bölönikódex történetéhez, ItK, megjelenés alatt.

${ }^{108}$ A vizitációról, a tanúkihallgatásokról és Háromszék korabeli helyzetéről több, új kutatás is beszámol részletesen: MolNÁR B. Lehel, A háromszéki unitáriusok 17. századi történetéhez. Toposz és valóság közt, KerMagv 118 (2012) 245-275. MoLNÁR Dávid, Valentin Radecke, Radecke életpályája püspökké választásától plébánossá választásáig (1615-1622), Keresztény Magvető, 121 (2015), megjelenés alatt.

${ }^{109}$ A szövegvariánsok dogmatikáját érintő lehetséges magyarázat említett tanulmányban részletesen, példákkal szemléltetve olvasható. 
tartott maga előtt, hiszen a kéziratban a lejegyző általi javítások, átírások többsége inkább rugalmasan használt, több változatban ismert variánsokról tanúskodik. Kézirat lévén erről a forrásról is elmondható, hogy számos saját, máshonnan nem ismert eltérést tartalmaznak az énekei. Ám megfigyelhető az is, hogy a szövegváltozatai több ponton nem az unitárius nyomtatványokéval mutatnak rokonságot, hanem az 1593-as bártfai evangélikus kiadással. Némely szöveg a debreceni református vonallal áll kapcsolatban a variánsokat tekintve, de a legtöbb esetben az unitárius nyomtatvánnyal fedezhetünk fel rokonságot. Ennek a sokrétü, a protestáns énekeskönyv-hagyomány minden ágát felmutató szöveg-közelítésnek az oka talán éppen abban keresendő, hogy rögzült, nyomtatott hagyomány híján Háromszéken az elérhető protestáns nyomtatványok, azok kéziratos másolatai alapján énekelhetett a gyülekezet, a saját dogmatikai álláspontjának megfelelöre szabva az énekeket. Emiatt a Bölöni-kódex a források közül talán a legjobb fennmaradt szemléltetőeszköze annak, hogy ha viszonylag elszigetelt helyen, nyomtatvány híján énekelnek a templomban, akkor az ott elérhető bármilyen protestáns, nyomtatott vagy kéziratos forrás és az énekelt, élőszavas hagyomány különös kontaminációjával találkozhatunk.

\section{Vasady-kódex, 1613-15 körül, S $27^{110}$}

A Vasady-kódexet ma már csak Dézsi Lajos hagyatékából ${ }^{111}$ és tanulmányából ${ }^{112}$ ismerjük, mert a második világháború alatt megsemmisült. A kódexet a Mindszenti Ferenc és Máté által szignózott és olykor datált $(1613,1615)$ énekeket tartalmazó része miatt a szakirodalom 1613-15 közötti, protestáns (de nem unitárius) forrásnak tartja. A dolgozat utolsó fejezetében a kódexről lesz még bővebben is szó, de arra már itt érdemes felhívni a figyelmet, hogy - ahogyan azt Debreczeni Sándor írja, - a kódex tartalmazott egy 1624 körül bemásolt unitárius kátét is. ${ }^{113}$ A leírások alapján a kódexnek legalább a felét az ekkoriban keletkezett, a Stoll által prózai szövegekként ${ }^{114}$ említett rész teszi ki, amelyek között a káté is megtalálható volt. A leírásokból kiderül azonban, hogy itt magyar nyelvü verses Ovidiusfordítások is voltak, illetve datálják is, így a későbbiekben részletezett helyszín és név alapján

\footnotetext{
${ }^{110}$ STOLL, i.m., 36-37.

111 A DÉzSI hagyaték Vasady-kódexet érintő részei megtalálhatók a Szegedi Tudományegyetem Egyetemi Könyvtárában. (Jelzetei: Ms 00620; Ms 00834.)

${ }^{112}$ DÉzsi Lajos, A Vasady-kódex, ItK, 1913, 14-27.

${ }^{113}$ DeBReCZENI Sándor, A Vasady-kódex eredete, Keresztény Magvető, 1940, 247-250.

${ }^{114}$ STOLL, i.m., 36.
} 
egyértelműen a kolozsvári unitárius kollégiumhoz köthető a kódexnek legalább a fele. A dolgozat utolsó fejezetében igyekszünk majd rámutatni arra is, hogy a mára már nem tanulmányozható énekek közül is van olyan, amely Dézsi forrásközlése alapján egyértelműen unitárius variánsnak mondható. Így a kódexet, ha nem is teljes egészében, de jórészt unitárius keletkezésűnek kell tekintenünk, s a datálásakor hangsúlyozni érdemes, hogy másoltak bele néhány éneket 1613-15 között, illetve számos szöveg 1624 körül, vagy 1624 után került bele, ekkor már egyértelműen unitárius környezetben. Mivel a kódex szövegei mára már csak Dézsi hagyatékából, illetve a Dézsi által kiadott szövegekből tanulmányozható, így a benne található variánsokról csak az utolsó fejezetben, az Adj már csendességet... (RPHA 2007) kapcsán ejtünk szót. Stoll Béla szerint a kódex 32, nagyrészt 16. századi keletkezésű vallásos éneket, s néhány világit tartalmaz, ${ }^{115}$ amelyből 11 ének megvan az RMNy 983-ban, az 1602-15 közötti kolozsvári unitárius énekeskönyvben is.

\section{Lipcsei-kódex, 1615, S $32^{116}$}

A kódex összeírója Nagy Tamás, az első részben főleg protestáns gyülekezeti énekek (zsoltárok és egyéb vallásos énekek) találhatók, a kódex második felében pedig bibliai, illetve történeti tárgyú históriák. A vizsgált korpusszal öt közös éneket tartalmaz, szövegváltozatai amelyeket sikerült összevetni ${ }^{117}$ - tulajdonképpen mindegyik nyomtatott hagyománytól távolinak mondhatók, néhol úgy tünik, hogy a szövegkorpusznak alig van köze bármely felekezet nyomtatott énekgyüjteményeihez.

\section{Csonka antifonálé, 1607-1632 között, S $143^{118}$}

\footnotetext{
115 STOLL, i.m., 36.

${ }^{116}$ STOLL, i.m., 39-40.

${ }^{117}$ Ez az egyetlen olyan forrás, amelyet nem sikerült kézbe venni sem, sem fotómásolaton tanulmányozni. A Szegedi Tudományegyetem könyvtárában található Dézsi-hagyaték alapján tájékozódtam, illetve Dézsi Lajos ItK-tanulmányának közölt szövegeit használtam föl. (DÉZsı Lajos, Régi magyar verseskönyvek ismertetése, VI, A Lipcsei-kódex, ItK, 1916/3, 305-343.)

${ }^{118}$ STOLL, i.m., 93-94. Bővebben: RMKT 17/4. 533-34, 691.
} 
A Csonka antifonálé neve, ahogyan arra Varga Imre is rávilágít, ${ }^{119}$ némileg félrevezető, hiszen a legtöbb graduálhoz hasonlóan tartalmaz antifónákat is, ám ez nem ad arra okot, hogy antifóna-gyüjteménynek nevezzük, hiszen ezek mennyisége teljesen azonosnak mondható a többi kéziratos graduálban szereplővel. A kézirat egyértelműen a magyar kolozsvári unitárius gyülekezetben keletkezett, s megfigyelhető, hogy szövegváltozatai sokkal kevesebb eltérést tartalmaznak a nyomtatott unitárius hagyományhoz képest, mint például a Bölöni-kódex, vagy a Kassai István énekgyüjteménye szempontunkból érdekes énekei. Így tehát erről a kódexről állíthatjuk, hogy inkább szoros másolás, mintsem lejegyzés eredménye. Az RMNy 983-mal, az 1602-15 közötti unitárius énekeskönyvvel 65 közös éneke van a gyüjteménynek. Varga Imre ${ }^{120}$ amellett érvel, hogy az antifonálé keletkezési ideje a két unitárius gyülekezeti énekeskönyv közé tehető, így ő 1607 és 1632 közé teszi. Érvei alapvetően a szerkezetre és az incipitjegyzékre támaszkodnak: a graduálrészt az első énekeskönyv szerkezetével rokonítja, ám felhívja arra a figyelmet, hogy a zsoltárok és egyéb énekek szerkezetében már nemcsak az egyéb énekek vannak ábécérendben, hanem a zsoltárok is. Ez viszont az 1632-es kiadás szerkezetével rokon, ahogyan arra részletes szerkezeti, ének-összetételbeli vizsgálatokat tartalmazó tanulmányában Etlinger Mihály kitér. ${ }^{121}$ Azt már Varga Imre is megjegyzi, hogy a graduál-részt nem számítva az énekek között 9 olyan éneket is találunk, amely a második nyomtatott unitárius énekeskönyvben benne van, az elsőben azonban nincs. Varga érvelése szerint ezek nagy része viszont bekerülhetett a protestáns forrásokból is. Fő érve, (amely miatt az 1632-es énekeskönyv megjelenése előttinek datálja a gyüjteményt,) az, hogy a Csonka antifonálé egyetlen Thordai-zsoltárt sem tartalmaz, márpedig a Thordai-zsoltárok voltak az 1632-es énekeskönyv legfőbb újításai. Etlinger Mihály említett tanulmánya végén azonban arra jut, hogy a „szöveganyag és a szerkezet tükrében a Csonka antifonálé helytelenül lett datálva, mivel az 1632-es kolozsvári unitárius kiadást másolja."122

A datálási problémát érdemes újravizsgálni, hiszen az incipitek egyezésein és a szerkezeten túl már összevetettük a szövegváltozatokat is.

Mivel a dolgozat célja, hogy az unitárius szöveghagyományról, illetve a protestáns szöveghagyományról mutasson be néhány jellemző tendenciát, így a Csonka antifonálé

\footnotetext{
${ }^{119}$ RMKT 17/4. 533.

${ }^{120}$ RMKT 17/4. 533-534.

${ }^{121}$ ETLINGER Mihály, A tyúk vagy a tojás? = mikro\&makro, Fiatal Kutatók Konferenciája Tanulmánykötet, Bp., 2013, 111-124 (Arianna Könyvek 6).

122 ETLINGER, i.m., 124.
} 
datálási kérdésének eldöntéséhez érdemes felsorakoztatni a szövegváltozatok összevetésének néhány példáját.

E vizsgálat tanúságait előre bocsátva azt mondhatjuk, hogy a Csonka antifonálé szövegváltozatai az 1602-15-ös unitárius énekeskönyv szövegeivel sokkal több ponton egyeznek, mint az 1632-es kiadáséival. Az értelmezéshez figyelembe kell venni az 1632-es kiadás fő jellemzőjét is. Ezt úgy összegezhetjük, hogy kijavítja az 1602-15 közötti énekeskönyv rím- és ritmushibáit, illetve dogmatikai változtatásokat is eszközöl némely szövegen. A durva rím- és ritmusrontásoknál megfigyelhető, hogy a Csonka antifonálé is gyakran javítja az első énekeskönyv-kiadás variánsát, $\mathrm{s}$ ezek a javítások gyakran megegyeznek azokkal, amelyek az 1632-es kiadásban találhatók. Emellett a Csonka antifonálénak természetesen vannak saját hibái, rontásai is, s emellett ritkán, de találunk különbséget a variánsok között alakváltozatok, rokon értelmü szóhelyettesítések, szórendcserék tekintetében is. A felsorolt jellemző változások gyakran egy éneken belül is keverednek, nem mondhatók egységesnek.

Ezek alapján úgy tünik, Varga Imrével egyetértve az 1632-es kiadás előtti kéziratnak kell tartanunk a gyüjteményt, amely már javít néhány hibát a korábbi kiadáshoz képest, de még messze nem tartalmaz az 1602-15-ös és az 1632-es kiadás közötti eltérésekből mindent, melyek száma egyébként elég csekély. Állításunk alátámasztását a következőkben néhány példával szemléltetjük.

A Szent Dávid próféta éneklö könyvének... (RPHA 1309) kezdetű ének az 1574-es komjáti kiadástól kezdve minden vizsgált énekeskönyvben megtalálható, a 8 . és 9. strófáját azonban egyedül az 1602-15 közötti unitárius énekeskönyv nem tartalmazza a nyomtatványok közül. A kéziratos források közül a Bölöni-kódex és a Csonka antifonálé sem tartalmazza - s utóbbi annak ellenére nem tartalmazza, hogy az 1632-es gyülekezeti énekeskönyvben már megtalálhatóak ezek a strófák. Külön érdekes, hogy a másoló/lejegyző a lap alján a 7. versszak után őrszóként hozza a 8. versszak legelejét: Ily nagy..., ám a következő oldalon annak ellenére, hogy itt egyértelmüen nem következett be csonkulás, nem ezzel, hanem az 1602-15 közötti nyomtatványnak megfelelően, azzal azonos módon a 10., az A te jóvoltodból... kezdetű strófával folytatja. A másoló/lejegyző tehát feltehetően ismerte azt a protestáns hagyományban meglévő két versszakot, amelyet az 1602-15-ös énekeskönyv kihagy, ám mivel a nyomtatványban nem szerepelt, így nem is másolta azt be a gyüjteménybe. Az 1632-es gyülekezeti énekeskönyv már beveszi a két versszakot, így a Csonka antifonálé ebben az esetben láthatóan nem ezt, hanem az első énekeskönyvet követi annak ellenére, hogy ismeri a kihagyott két strófát a másoló. 
Az Aki az Istent megismerheti... kezdetü zsoltárparafrázis (RPHA 68) is érvet szolgáltat Varga Imre datálása mellett. Az ének az 1560-as óvári kiadástól kezdve minden nagy énekgyüjtemény része, s elmondható róla, hogy az unitárius szövegvariáns a legegyedibb. A szereztetés helyére utaló záró strófa a különböző kiadásokban változik: az 1582-es detrekői kiadás hagyja el először, s illeszt a helyére doxológiát. Az 1602-es debreceni kiadás is elhagyja, ám a helyére a zsoltár számára és tartalmára hivatkozó strófát tesz be. Az 1602-15 közötti unitárius kiadás szintén elhagyja a kolofont, de a helyére nem illeszt semmit, míg az 1632-es kiadás egy új, eddig nem ismert hivatkozó strófát közöl, amely megtalálható lesz az 1697-es gyülekezeti énekeskönyvben is. A Csonka antifonálé az 1602-15 közötti nyomtatványhoz hasonlóan nem hoz sem kolofont, sem hivatkozó strófát.

A dogmatikai változtatásokra példát találunk az Úrnak szolgái, no, dicsérjétek... kezdetű zsoltárban (RPHA 1447). Az ének az 1560-as óvári kiadástól kezdve része a gyülekezeti énekhagyománynak, s az 5. versszakában található, az Úristent és Jézus Krisztust egyformán magasztaló formulát az 1602-15 közötti unitárius énekeskönyv a protestáns hagyománnyal azonos formában hozza:

Miként öröktöl te dicsértettél, felséges Úristen, most és mindenkor te szent fiaddal áldassál, Úristen.

Ebben a strófában dogmatikai értelemben az Atya és a Fiú egyforma módon való tisztelése jelenik meg, amely a kevésbé radikális unitárius teológiai elvekkel teljesen összhangban van. Figyelemre méltó azonban, hogy ezt a formulát a többi unitárius nyomtatványban és a Csonka antifonáléban megváltoztatják. Az 1632-es és az 1697-es gyülekezeti énekeskönyv megváltoztatja a második sort erre: „most és mindenkor te szent fiadban áldassál, Úristen."

Ez az aprónak tűnő változás az értelmen annyit módosít, hogy hangsúlyozásra kerül: a Fiúisten dicséretében az Atya dicsérete van benne.

A Csonka antifonálé azonban nem az 1632-es változatot hozza, de nem is az 1602-15 közötti kiadásét. Variánsa egyetlen ma ismert nyomtatványéval azonos, az 1700-as kiadású kolozsvári unitárius magánhasználatra szánt énekeskönyvével. Ez alapján viszont azt feltételezhetjük, hogy - mivel az 1700-as kiadás az elveszett 1623-as, illetve a makulatúrában fennmaradt 1635-ös unitárius ima-énekeskönyvnek a bővített kiadása, - a Csonka antifonálé az 1623-as kiadás variánsa alapján hozhatta a következő szöveget: „,most és mindenkor szent fiad által áldassál, Úristen., 
Noha ennyi változtatásból nehezen vonhatunk le komoly dogmatikai összefüggésekre utaló tanúságot, de úgy tünik, nem véletlen müve az eltérés. (Erről a dogmatikát érintő fejezetekben bővebben szólunk még.) A fiú, tehát Jézus által is áldott Atya jelenik meg az apró változás miatt a versben, nem pedig az ember által egyformán áldott Atya és Fiú.

Az Egész Izraelt... kezdetü Bogáti Fazakas-zsoltár (RPHA 313) hasonló tendenciákat mutat: a 3. strófájában az 1602-15 közötti nyomtatványban elrontott ritmust a Csonka antifonálé ugyanúgy, ugyanolyan formában javítja, mint az 1632-es kiadás és az összes többi kézirat és/vagy nyomtatvány. Ám a 3. versszakban az 1602-15 közötti énekeskönyv és az 1632-es énekeskönyv variánsai között két rokon értelmü, apróbb értelemmódosító eltérés is van, s a Csonka antifonálé mindkét esetben az 1602-15 közötti kiadás variánsát követi, nem az 1632-es kiadásét.

Noha a dolgozatban nincs mód az összes példát szemügyre venni, de a fent bemutatott sajátosságok szinte az összes vizsgált szövegben megtalálhatók. Így a Csonka antifonálét Varga Imrével egyetértve, a szerkezeti és énekmutató szerinti összevetést a szövegváltozatok vizsgálatával kiegészítve az 1632-es gyülekezeti énekeskönyv kiadása előtti időszakra kell tennünk. Ám Etlinger Mihály vizsgálata rámutat arra, hogy a Csonka antifonálé a viszonylag szoros követés mellett az 1602-15-ös gyülekezeti énekeskönyvhöz képest új szerkezettel hozza az énekeket, amely szerkezet (mi több, akár maga a gyüjtemény is) közvetlen előzménye lehetett az 1632-es kiadás gyakorlatának.

\section{Kassai István énekgyüjteménye, (Stoll: Kassai István toldaléka) 1629, S 1009}

A kéziratról a későbbiekben részletesen is lesz még szó, így alább csupán a mostani gondolatmenetünk szempontjából legfontosabb mozzanatokat ismertetjük. $\mathrm{Az}$ énekgyüjtemény 1629-ben keletkezhetett, a bejegyzés szerint Kassai István tulajdonában volt, s a lejegyzője Makai Mihály. Az énekek toldalékként járulnak Erasmus Novi Testamenti aeditio postrema címü müvének másolatához, s Korzenszkyvel egyetértve mondhatjuk, hogy az énekek egyértelmüen unitárius dogmatikával rendelkeznek. ${ }^{124}$

\footnotetext{
${ }^{123}$ STOLL, i.m., 414-415. A kötet énekszövegeit részletes tanulmányokkal és elemzésekkel közzéteszi: KoRZENSZKY Richárd, Kassai István énekgyüjteménye, Pannonhalma, 1997, (Pannonhalmi füzetek 41).

${ }^{124}$ KORZENSZKY, i.m. 26.
} 
A kézirat 26 énekéből 12 megtalálható az 1602-15 közötti kolozsvári unitárius énekeskönyvben, s ezáltal a gyüjtemény ezzel a nyomtatvánnyal mutat a legtöbb azonosságot incipitek egyezése tekintetében, ahogyan azt Korzenszky is megállapítja.

Korzenszky többször kiemeli, hogy az énekek többségének lejegyzése feltehetően emlékezetből történt. Az emlékezetből lejegyzett variánsok némelyikéről, s a kézirat dogmatikai jellemzőiről a későbbiekben szólunk, ám azt mindenképp megállapíthatjuk, hogy a kolozsvári unitárius egyház szövegei alapján készült gyüjtemény nem követi szorosan az unitárius nyomtatványokat, $\mathrm{s}$ nem szolgai másolatokat közöl az unitárius gyülekezeti énekekről.

\section{Kuun-kódex, 1621-47 között, S 40}

A kódex első fele protestáns énekeket tartalmaz, a korpusszal közös 6 ének is innen került ki. Ezek Nagy Miklós 1621-es másolatából maradtak fenn. Az 1634-től másolt Máriaénekek mutatják, hogy később katolikus környezetben íródott tovább a kódex. A Kuun-kódex szövegváltozatai többségében ugyanazt a tendenciát mutatják, mint amit a Bölöni-kódex esetében is láthatunk: a kéziratos hagyományba kerülő szövegek feltehetően nem valamely ismert nyomtatott énekgyüjteményről készültek közvetlenül, hiszen számos saját eltérést tartalmaznak, amely eltérések okait mára már teljes bizonyossággal nem állapíthatjuk meg. Elképzelhető, hogy az emlékezetből idézés az eltérések oka (bár ez esetben akkor rendkívül jó versíró-készséggel megáldott lejegyzőt kell feltételeznünk, aki ha nem jut eszébe egy strófa, ír helyette másikat), vagy éppen valóban mára elveszett kéziratokból és nyomtatványokból is szemezgetve jegyzi le a szövegeket valaki. (Ami, valljuk be őszintén, túl szép ahhoz, hogy igaz legyen. A 17. század elejének irodalmi viszonyait ismerve nehezen elképzelhető, hogy valaki több nyomtatványt és kéziratot a kezében tartva tud bárhol gyüjteményt összeválogatni a maga kedvére. A legtöbb „vidéki”, kisebb városi gyülekezetben jó, ha egy-két példány volt meg egy énekgyüjteményből, nemhogy gyűjtemények sokasága.) Éppen emiatt tartjuk a legelfogadhatóbb álláspontnak azt, hogy az ilyen jellegű gyüjtemények többsége valóban emlékezetből, javarészt a lejegyző által ismert és énekelt énekhagyományt rögzíti, amely eltér

\footnotetext{
${ }^{125}$ STOLL, i.m., 44-45. Első ismertetője DÉZSI Lajos, Régi magyar verseskönyvek ismertetése V, A Kuun-kódex, ItK, 1916, 50-74. A közös énekek összevetését a facsimile-kiadás alapján készítettem. A Kuun-kódex, s.a.r. VARGA Imre, Bp., 1979. I-II.
} 
a nyomtatott protestáns szöveghagyománytól, s a szövegek nagyobb változást, nagyobb variabilitást mutatnak, mint a nagyobb felekezeti nyomdahelyeken egymás után nyomott énekeskönyvek.

\section{Incipitegyezés és textológiai kapcsolatok: a gyülekezeti énekek sajátos helyzete}

A régi magyar gyülekezeti éneknek mint müfajnak többféle megközelítési módja létezik. A müfajhoz egyrészt szokás a klasszikus filológiai módszerrel közelíteni, s a nyomtatott és kéziratos gyülekezeti énekgyüjteményekben található variánsokat stemmával ábrázolni.

Ez a megközelítés a gyüjteményes variánsok között szoros hagyományt, textológiailag egyértelmü és világos kapcsolatot feltételező módszerrel vizsgálja az anyagot, s az egyes gyüjtemények között ez alapján állít fel összefüggést. ${ }^{126}$

A gyülekezeti énekeskönyvek esetében az egyazon felekezethez tartozó, egyazon nyomdahelyen kiadott énekgyüjtemények variánsai többségükben valóban ilyen jellegü kapcsolatot mutatnak egymással, a szövegek variabilitása a nyomtatott hagyományban kisebb. Kisebb, ám létező jelenség a variabilitás.

Ám ha a kéziratos forrásokat is vizsgáljuk, mindjárt láthatóvá válik az, hogy ugyanazon a felekezeten belül, ugyanabban az időben is erős változataiban élt a gyülekezeti ének. Ez a variálódás a nyomtatott hagyományon is látható, a markánsabb jegyek viszont a kéziratos lejegyzésekben figyelhetők meg.

Ha nem felekezeten belül, hanem a protestáns énekgyakorlaton belül vizsgáljuk a szövegeket, akkor is találkozunk olyan gyülekezeti énekkel, amely közel száz év alatt, tehát az általunk vizsgált évtizedekben alig változik.

Ilyen szöveg például az általunk vizsgált anyagban a Felséges Isten, mennynek, földnek Ura és embereknek... kezdetủ gyülekezeti ének (RPHA 411). ${ }^{127}$ Az ének 1560-tól szinte minden egyes gyülekezeti énekeskönyvben megtalálható, és - főleg az unitáriusokhoz

\footnotetext{
${ }^{126}$ Ilyen megközelítési móddal találkozhatunk a zsoltárok és a gyülekezeti énekek vizsgálatánál a leggyakrabban. A históriák és az énekek kapcsán a gyülekezeti énekek hagyományozódását ilyen módon, együttesen vizsgálja PAP Balázs, Históriák és énekek, Pécs, 2014 (Pannónia Könyvek). E hagyomány mentén mutatja be a Csonka antifonálé és az unitárius gyülekezeti énekeskönyvek kapcsolatát: ETLINGER Mihály említett tanulmánya.

${ }^{127}$ Kéziratos forrásai a vizsgált korpuszban: Vasady-kódex (csak az első strófa ismert); Bölöni-kódex ,Csonka antifonálé. Nyomtatott kiadásai: 1560 Óvár; 1566 Várad; 1569 Debrecen; 1570 Debrecen; 1574 Komjáti; 1579 Debrecen; 1582 Detrekő; 1590 Debrecen; 1593 Bártfa; 1602 Debrecen; 1602-14 Bártfa; 1602-15 Kolozsvár; 1632 Kolozsvár; 1697 Kolozsvár.
} 
köthető - kéziratos változata is ránk maradt. A szövegböl a felsorolt források mindegyikét összevetve 9 változást tudtunk regisztrálni. Ezeket, - mivel a dolgozat a későbbiekben a csekélyebb számú, szövegváltozást nem mutató gyülekezeti énekhagyománnyal nem foglalkozik - alább ismertetjük. A lábjegyzetben jelzett eltérések mellett igyekszünk feltüntetni az eltérések lehetséges magyarázatait, amely e szöveg esetében nem, vagy alig mutat az éneklésnek, az énekeltségnek betudható változást.

Felséges Isten, mennynek, földnek Ura, és embereknek kegyelmes vezére, minden állatoknak kegyes táplálója, és éltetője.

Tégedet vallunk kegyelmes atyánknak, bünös emberek, mi oltalmazónknak, Krisztus Jézusért kegyes táplálónknak, gondviselönknek.

Mostan, ${ }^{128}$ Úristen, ily $^{129}$ nagy nyavalyánkban, hozzád kiáltunk keserüségünkben, $n e^{130}$ hagyj el ${ }^{131}$ minket ily nagy szükségünkben, árvaságinkban.

Ígéretedet teljesitsd ${ }^{132}$ meg rajtunk, hogy dicsértessék szent neved közöttünk, ne örüljenek pogányok mirajtunk, te légy mivelünk.

Téritsd meg, ${ }^{133}$ Úristen, a bálványozókat,

${ }^{128}$ most: 1593 Bártfa. Az énekeskönyv ritmust ront, de sem a kéziratos források, sem a későbbi bártfai kiadás nem követi, feltehetően nyomdai hiba lehetett.

${ }^{129}$ mi: 1560 Óvár, 1566 Várad, 1569 Debrecen, 1570 Debrecen, 1574 Komjáti, 1579 Debrecen, 1582 Detrekő, 1590 Debrecen, 1593 Bártfa, 1602 Debrecen, 1602-14 Bártfa, Bölöni-kódex. Látható, hogy az ,ily” mutató névmás csak a Csonka antifonáléban és az unitárius nyomtatványokban szerepel, minden más forrás (még a szintén unitárius Bölöni-kódex is) a „mi” személyes névmást hozza.

${ }^{130}$ hogy ne: 1560 Óvár, 1566 Várad, 1569 Debrecen, 1570 Debrecen, 1574 Komjáti, 1579 Debrecen, 1582 Detrekő, 1590 Debrecen, 1593 Bártfa, 1602 Debrecen, 1602-14 Bártfa.

131 nincs „el”: 1560 Óvár, 1566 Várad, 1569 Debrecen, 1570 Debrecen, 1574 Komjáti, 1579 Debrecen, 1582 Detrekő, 1590 Debrecen, 1593 Bártfa, 1602 Debrecen, 1602-14 Bártfa, Bölöni-kódex. Szintén csak az unitárius hagyomány tér el a többitől: a „hogy ne hagy minket...” helyett a „,ne hagyj el minket...” formát használja. A metrum mindkét esetben kijön, nem lényeges a változás. A Bölöni-kódex viszont látható, hogy kontaminálja az unitárius nyomtatványokban szereplö változatot és a többi protestáns variánst, s a két különböző variáns keveredéséből egy harmadik, rontott metrumú, eggyel kevesebb szótagszámú sor jön ki: „,ne hagyj minket ily nagy szükségünkben..."

132 tellyets: 1570 Debrecen. Nyomdahiba lehet.

133 rontsd meg: 1560 Óvár, 1569 Debrecen, 1570 Debrecen, 1574 Komjáti, 1579 Debrecen, 1593 Bártfa, $1602-$ 14 Bártfa. A dolgozat későbbi fejezeteiben több ízben említésre kerül, hogy az unitárius források rendszeres eljárásának tekinthető az itt tapasztalt változtatás: az ellenség letiprásáról, megtöréséről, megrontásáról szóló részeket az unitárius nyomtatványok és kéziratok is következetesen „enyhítik”, s helyettük a „téritsd meg” formula lesz megtalálható még akkor is, ha ez ritmust ront. Ebben az esetben is ez történik: minden unitárius nyomtatvány és kézirat az „enyhébb”, az ellenség megtérítését kérő variánst hoz, amely viszont szótagtöbbletet tartalmaz. 
kik hatalommal kergetik lelkünket, és kik csúfolják a te szent fiadat, Krisztus urunkat.

${ }^{134}$ Tartsd meg Úristen, a te híveidet, és öregbitsed hitünket lelkünkbe, halálunk idején ne essünk kétségbe, ördög kezébe.]

Atya Istennek örökké dicsöség, a Krisztus által ${ }^{135}$ adassék tisztesség, ki szent lelkével minket vigasztaljon, minden időben. ${ }^{136}$

Látható, hogy ebben a szövegben - ahogyan ez általában is mondható vizsgálódásunk anyagára - a legtöbb eltérést az unitárius variánsok hordozzák. Ennek az lehet az oka, amelyet már az RMKT 17/4. jegyzete is említ, ${ }^{137}$ hogy az unitárius felekezet térben is távolabb esik a többi, nyomtatott gyülekezeti énekhagyománnyal rendelkező felekezettől. A másik ok pedig véleményünk szerint az, hogy az első nyomtatott unitárius gyülekezeti énekeskönyv a többi felekezeti énekeskönyvhöz képest csak igen későn, 1602-15 között jelenik meg. Nyilvánvaló, hogy addig is énekeltek a templomban, de nyomtatvány, nyomtatott szöveghagyomány híján valószínüsíthetjük, hogy más felekezetek nyomtatott énekeskönyveinek szövegeit átalakítva (legalábbis dogmatikailag az unitáriusok számára megfelelő hitelvekre szabva), és kéziratos énekgyüjteményekből tehették ezt. Mivel a nyomtatás rögzítő, a szövegeket állandósító jellege nem érvényesülhetett nyomtatott énekeskönyv híján, így a szövegek évtizedekig nagyobb variabilitást mutattak, jobban változhattak a kéziratos és az énekelt hagyományban, mint azoknál a felekezeteknél, ahol olykor évente, pár évente újranyomták az énekeskönyvek rögzült, minimálisan változtatott anyagát.

térítsd: 1582 Detrekő. Ez a variáns is „,enyhébb”, mint a többi, itt a ritmus is kijön.

${ }^{134}$ plusz strófa: 1566 Várad. Az első nyomtatott megjelenésekor ennek a szövegnek eggyel több strófája volt, mely a későbbi összes kéziratos és nyomtatott forrásból kikopott.

${ }^{135}$ és a Krisztusnak: 1560 Óvár, 1566 Várad, 1569 Debrecen, 1570 Debrecen, 1574 Komjáti, 1579 Debrecen, 1582 Detrekő, 1590 Debrecen, 1593 Bártfa, 1602 Debrecen, 1602-14 Bártfa. Az unitárius források mindegyike dogmatikai okokból változtat. A dogmatikai változás nem ,alulról”, a gyülekezet felöl jövő változás eredménye, hanem a teológiát jól ismerő kántor, lelkész vagy tanító, esetleg a szerkesztő eszközölhette az ilyen jellegü változásokat. A későbbiekben látjuk majd, hogy a Krisztus által az Istent dicsérő formula az unitárius variánsokban általánosnak mondható, mivel így a Krisztus és az Úr közötti hierarchikus viszony kifejeződik.

${ }^{136}$ a Szentléleknek egyenlő méltóság,/mennyben dicsőség: 1560 Óvár, 1566 Várad, 1569 Debrecen, 1570 Debrecen, 1574 Komjáti, 1579 Debrecen, 1582 Detrekő, 1590 Debrecen, 1593 Bártfa, 1602 Debrecen, 1602-14 Bártfa. A záró doxológiát csak az unitárius források változtatják meg a nekik megfelelő dogmatikai elvek szerint. ${ }^{137}$ RMKT 17/4, 527. 
A fenti példát nézve - ha az unitárius hagyomány sajátos voltát leszámítjuk - azt láthatjuk, hogy néhány nyomdai hibán kívül gyakorlatilag nem találunk eltérést a szövegváltozatok között.

Szintén alig tartalmaz eltérést az összes forrást összevetve a Minden állat dicsér, Úristen... kezdetű zsoltár (RPHA 952). ${ }^{138}$ A felező tizenkettesekből álló, história-szerüen felépülő szöveg 22 strófájában mindössze 9 apró, föleg toldalékváltozásból ${ }^{139}$ álló eltérés figyelhető meg a hagyományban. Feltünő, hogy ez a szöveg, illetve még számos olyan ének, amely kéziratos hagyományból nem maradt ránk, nem mutat nagy eltéréseket szövegváltozatok tekintetében. Az egyes kéziratokban szereplö, ott lejegyzésre kerülő szövegek nyilván ismertek, népszerüek, és a lejegyzői gyakran emlékezetből az általuk ismert variánst írják le. Az ismertség, az énekeltség, az emlékezetből idézés mind-mind olyan jelenség, amely kedvez a szövegváltozásnak, a variánsok kialakulásának. Ezek a szövegek nem kerültek be a kéziratos énekhagyományba, így a nyomtatásban rögzített formái kevésbé voltak változásnak kitettek, mint azok a szövegek, amelyek éneklésben, kéziratosan és nyomtatásban egyaránt terjedtek.

Más magyarázhatja azt, hogy az Úrnak szolgái, no dicsérjétek... kezdetü ének (RPHA 1447) az unitárius variánsokat nem számítva - amelyek ebben az esetben is több eltérést, főleg dogmatikai eltérést tartalmaznak - alig változik 1566-os váradi első nyomtatott megjelenésétől. Ez a rövid, párrímes, kétsoros strófaszerkezetủ ének egyrészt szintén csak a nyomtatott hagyományból maradt fönn. (Nem számítva a Csonka antifonálét, mely az unitárius gyülekezeti énekeskönyvekböl viszonylag pontosan, nagy odafigyeléssel másolt énekgyüjtemény.) Vadai István rámutat arra, ${ }^{140}$ hogy a szóbeli alkotásmódra, illetve a szóbeli megörzésre és felidézésre egyaránt jellemző jegy a régi magyar irodalomban a kétsoros, párrímes szerkesztési mód. Vadai kifejti, hogy a 16. század derekáig gyakori forma, mely alapvetően a szóbeli produkálást és reprodukálást segíti, a későbbiekben, a nyomtatás megjelenésével, az írásbeliség elterjedésével elhalványul. Így nem kizárt, hogy a szóbeli hagyományban élő, népszerü, a szöveg megőrzését segítő forma is szerepet játszhatott abban, hogy ez a szöveg nem variálódott annyira, mint a gyülekezeti énekek nagy többsége.

\footnotetext{
138 Nyomtatott forrásai: 1574 Komjáti; 1582 Detrekő; 1590 Debrecen; 1593 Bártfa; 1602 Debrecen; 1602-14 Bártfa, 1602-15 Kolozsvár, 1632 Kolozsvár, 1697 Kolozsvár.

139 Például a 19. versszak 3. sorában három különböző toldalékkal szerepel ugyanaz a szó a különböző variánsokban: egyházaddá/egyházaddal/egyházadban.

${ }^{140}$ VADAI István, Szóban kettő - irva négy. Az oralitás metrikájáról, Doromb: közköltészeti tanulmányok, 1, szerk. CSÖRSZ Rumen István, Bp., reciti, 2012. http://www.reciti.hu/wp-content/uploads/05 Vadai.pdf Letöltve: 2015. 05. 12.
} 


\section{Stemma - háló}

Gyülekezeti ének alatt alapvetően a templomban, a közösség által közösen énekelt szövegek csoportját értjük, melyek - bár rendelkeznek szerzővel, de a közösség kezdi énekelni, s ezáltal az élőszóban/énekben variálni, változtatni, - a nyomtatott hagyományban is, a kéziratosban is számos variánsban jelennek meg. Mivel tehát a gyülekezeti ének a fixált, rögzített nyomtatott hagyomány mellett alapvetően hangzóságában, a gyülekezet által a templomban énekelve létezett, a gyülekezeti énekeskönyvek szöveghagyományának kapcsolatát, a gyülekezeti énekek egyes hordozókban található szövegváltozatainak leírását a stemmák mellett más megközelítésben is érdemes tárgyalni. Mivel az általunk tárgyalt anyag szöveghelyzete sok összetevős, ezért stemma nem építhető az egyes énekeskönyvek variánsai között. Az ilyen, nagyszámú szöveganyagon végzett, sokösszetevős, bonyolult textológiai helyzetben a lachmanni elveket nem minden esetben alkalmazhatjuk - sőt, az ilyen esetekre Lachmann sem alkalmazza.

Éppen a hangzóság, az énekeltség lehet annak az oka, ha egy gyülekezeten belül ugyanaz a szöveg eltérő variánssal rendelkezik az egyes nyomtatott kiadásokban, (nem ritkán egy-egy énekeskönyvön belül is több változatban él egy szöveg) ${ }^{141}$ és a kéziratos forrásokban is. Talán éppen az énekeltség miatt nem érdemes elveszett kéziratos és nyomtatott forrásokat feltételezni, melyekből az előző nyomtatott kiadáshoz képest az új nyomtatvány létrehozója gondosan válogatva választja ki a neki leginkább megfelelő variánst, öt-hat, mára nem ismert

${ }^{141}$ Erről Pap Balázs több ízben is említést tesz. PAP, i.m., 103-109. A szövegelemzései érintik az Úristen, ki mennyben lakozol... kezdetü éneket (RPHA 1438), amely az 1582-es detreköi énekeskönyvben kétszer van meg, illetve a mi anyagunknak is részét képező, Szegedi Gergelynek tulajdonított 29. zsoltárt, a Dávid prófétának imádkozásáról... kezdetűt (RPHA 242), mely az 1566-os váradi kiadásban szerepel kétszer. Ennél a zsoltárnál Pap Balázs a kétszer kétféle változatban szereplő szövegváltozatról azt feltételezi, hogy a váradi énekeskönyv szövegkiadója sem egy szövegböl dolgozott. (107.) Pap Balázs a szövegösszevetések alapján arra jut, hogy a források és szöveghagyományozódás kérdése jóval bonyolultabb annál, ahogyan azt Schulek Tibor ábrázolta, de teljes, kereshető és kérdező felülettel ellátott szövegbázis híján a bonyolultabb hagyomány jelenleg nem feltárható. (109.) Úgy gondoljuk, az ilyen esetekben is érdemes megfontolni, hogy a gyülekezeti énekek variánsokban élését, hagyományozódását feltételezzük az énekeltségük, a kéziratos és nyomtatott terjedésük miatt. E különös, összetett mediális hordozók éppúgy elképzelhetők annak magyarázatára, hogy egy gyülekezeti énekeskönyvben miért szerepel egy ének kétféleképp, mint az, hogy a kötet szerkesztője 4-5, akár több forrást a kezében tartva válogat a szövegek közül. A gyülekezet számára ismert kétféle variáns nyomtatásban való rögzítését sem zárhatjuk ki. Természetesen teljes bizonyosságot csak akkor nyerhetünk az egyik vagy a másik álláspont érvényességéröl, ha lehetséges lesz a teljes szövegbázis összevetése. Reményeink szerint az RPHA és a készülő RPHA 17 együttesen ezt teszi majd lehetővé. 
gyülekezeti énekgyüjteményt a kezében tartva. Sokkal valószínűbbnek tarthatjuk, hogy a gyülekezet által énekelt variánsok is hatnak a nyomtatásban megjelent forrásokra, a kéziratos énekgyüjtemény-lejegyzők pedig a legtöbb esetben a saját gyülekezetük által énekelt variánst fejből ismerve, esetleg az éppen használatban lévő nyomtatott énekgyüjteményt maguk előtt tartva jegyzik le ezeket az énekeket.

H. Hubert Gabriella a gyülekezeti énekeskönyvekről írott monográfiájának végén rámutat arra, hogy „,[a] 16-17. századi énekeskönyvek történetét áttekintve, és nagyobb mennyiségü elveszett kéziratot feltételezve, a családfa-állitás helyett egy énekeskönyv-háló megrajzolása tünik helytállónak. "142 $\mathrm{H}$. Hubert Gabriella a monográfiájában általa ismertetett minden adat figyelembe vételével (címadás, szerkezeti egységek, előszavak utalásai, incipitjegyzék stb.) jut ezekre a megállapításokra.

A dolgozat által tárgyalt 118 gyülekezeti éneknek a fentebb ismertetett forrásokban található variánsait összevetve a H. Hubert Gabriella által megállapított hálózatos kapcsolatok $^{143}$ látszanak a legtöbb esetben érvényesnek lenni, néhány apró kiegészítéssel, mely főként az unitárius énekgyüjteményeket illeti.

Ha stemmával próbálnánk meg ábrázolni az egyes nyomtatott és kéziratos énekgyüjtemények közötti kapcsolatot úgy, hogy a szövegváltozatokat nem vetjük össze, csupán az egyező incipiteket vesszük figyelembe, félrevezető eredményre jutunk. A gyülekezeti énekek véges számúak, s könnyen belátható, hogy noha folyamatosan születnek új énekek, így a számuk bővül, az egyes felekezetekben (a korban még gyakori ki- és betérés, illetve a felekezetek közötti kapcsolatok miatt) közös, a hívek által ismert énekeket énekelnek, hiszen a 16. század közepétől már a szegényesen fennmaradt források ismeretében is látszik, hogy a protestáns felekezetek rendelkeznek kialakult énekanyaggal. Éppen ezért a felekezetiesedés korszaka után is mindhárom nagy felekezet (református, evangélikus és unitárius) használja a kialakult énekkincset. Emiatt az incipitek egyezése az egyes nyomtatványokban vagy kéziratokban nem feltétlen jelent közvetlen leszármazást, egymásból ágazó kiadást vagy gyüjteményt. Véleményünk szerint tehát a közvetlen ágrajz elkészítéséhez, hipotéziséhez konkrét, összehasonlító textológiai vizsgálatra van szükség.

Noha - ahogyan azt a bevezetőben kifejtettük - a 118, az 1602-15 között keletkezett unitárius énekeskönyvben előforduló gyülekezeti ének összevetése a többi protestáns gyüjtemény változatával még messze nem ad teljes, minden tendenciára érvényesnek mondható képet, de úgy gondoljuk, csupán az incipitek egyezésének vizsgálatánál

\footnotetext{
${ }^{142}$ H. HUBERT, i.m., 280.

${ }^{143}$ H. HUBERT, i.m., 281.
} 
mindenképp reálisabb, pontosabb képet kaphatunk, ha a variánsokat nagyobb számú forrás ismeretében összevetjük.

Ha a vizsgált anyagot, tehát a 118 unitárius gyülekezeti ének szövegváltozatát alapul véve nézzük, az incipitek egyezése a következőképp alakul. Az alábbi táblázatban azt jelezzük, hogy egy-egy forrásban az 1602-15 közötti unitárius nyomtatvány 118 éneke közül mennyi található meg, a 15 éneknél kevesebb egyezést tartalmazó forrásokat a nyomtatványok esetében már nem regisztrálva. A táblázatban a legtöbb egyezést tartalmazó forrástól haladunk a legkevesebb egyezést mutatóig.

\begin{tabular}{|c|c|c|}
\hline \multicolumn{3}{|c|}{ NYOMTATVÁNYOK } \\
\hline $\begin{array}{l}\text { Nyomtatvány } \\
\text { azonosítója (RMNy-szám, } \\
\text { kiadás helye, ideje) }\end{array}$ & Nyomtatvány felekezetisége & \begin{tabular}{lrr}
\multicolumn{1}{c}{ Az } & RMNy & 983. \\
vizsgált & \multicolumn{2}{r}{ gyülekezeti } \\
énekeivel & közös & incipitek \\
száma & &
\end{tabular} \\
\hline $\begin{array}{l}\text { RMNy } 1541 . \\
\text { 1632, Kolozsvár. }\end{array}$ & unitárius & 111 ének \\
\hline $\begin{array}{l}\text { RMK I. 1503. 1697, } \\
\text { Kolozsvár }\end{array}$ & unitárius & 93 ének \\
\hline $\begin{array}{l}\text { RMNy 713. 1593, } \\
\text { Bártfa }\end{array}$ & evangélikus & $\begin{array}{l}67 \text { ének (Ebböl két } \\
\text { ének ebben a forrásban } \\
\text { duplán szerepel.) }\end{array}$ \\
\hline $\begin{array}{l}\text { RMNy 965. 1602-14, } \\
\text { Bártfa }\end{array}$ & evangélikus & $\begin{array}{l}61 \text { ének (Ebböl egy } \\
\text { ének ebben a forrásban } \\
\text { duplán szerepel.) }\end{array}$ \\
\hline $\begin{array}{l}\text { RMNy 513. 1582, } \\
\text { Detrekő }\end{array}$ & evangélikus & $\begin{array}{l}60 \text { ének (Ebböl egy } \\
\text { ének ebben a forrásban } \\
\text { duplán szerepel.) }\end{array}$ \\
\hline $\begin{array}{l}\text { RMNy 886. 1602, } \\
\text { Debrecen }\end{array}$ & református & 59 ének \\
\hline $\begin{array}{l}\text { RMNy 640. 1590, } \\
\text { Debrecen }\end{array}$ & református & 58 ének \\
\hline $\begin{array}{l}\text { RMNy } 353 \text { I-II. 1574, } \\
\text { Komjáti }\end{array}$ & evangélikus & 49 ének \\
\hline
\end{tabular}




\begin{tabular}{|c|c|c|}
\hline $\begin{array}{l}\text { RMNy 264. 1569, } \\
\text { Debrecen }\end{array}$ & református & 41 ének \\
\hline $\begin{array}{l}\text { RMNy 429. 1579, } \\
\text { Debrecen }\end{array}$ & református & 39 ének \\
\hline $\begin{array}{l}\text { RMNy 222. 1566, } \\
\text { Várad }\end{array}$ & protestáns & $\begin{array}{l}39 \text { ének (Ebböl két } \\
\text { ének ebben a forrásban } \\
\text { duplán szerepel.) }\end{array}$ \\
\hline $\begin{array}{l}\text { RMNy 276. 1570, } \\
\text { Debrecen }\end{array}$ & református & 34 ének \\
\hline $\begin{array}{l}\text { RMNy 160. 1560-61. } \\
\text { Óvár, Kassa, Debrecen }\end{array}$ & protestáns & 34 ének \\
\hline $\begin{array}{l}\text { RMNy 1290. 1623, } \\
\text { Kolozsvár }\end{array}$ & unitárius & 17 ének \\
\hline $\begin{array}{l}\text { RMK I. 1558-59. } \\
\text { 1700, Kolozsvár }\end{array}$ & unitárius & 17 ének \\
\hline
\end{tabular}

Ha az énekegyezéseket az incipitek számának egyezése alapján vizsgáljuk, látható, hogy az 1602-15 között keletkezett unitárius gyülekezeti énekeskönyv (saját, későbbi bővített újrakiadásain kívül) a bártfai evangélikus énekeskönyvekkel tartalmaz nagyszámú egyezést. A szövegváltozatok vizsgálata azonban nem pontosan ezt mutatja. A bártfai evangélikus kiadások énekvariánsai sok esetben még az 1582-es detrekői, és az 1574-es komjáti kiadástól is távol állnak, (noha van, ahol követik), de számos esetben saját további strófákat, saját változtatásokat is tartalmaznak. Hozzá kell tennünk, hogy e két bártfai kiadás (az 1593-as és az 1602-14 közötti) eleve számos olyan szöveget tartalmaz, amely egyértelmüen rontott szöveg, s a romlása nemigen magyarázható mással, mint azzal, hogy a szedő, a nyomdász nem tudott jól magyarul.

Az incipitek egyezésének vizsgálata azért sem elégséges a stemma állításhoz, vagy a felekezeti énekeskönyvek közötti kapcsolatok megállapításához, rekonstrukciójához, mert az egyes kiadások különböző mennyiségü énekanyagot tartalmaznak. Látható, hogy az unitárius magánhasználatra szánt énekeskönyvekkel az 1602-15 közötti unitárius énekeskönyv csupán 17 közös éneket tartalmaz. Ez az adat torz lenne, ha nem tennénk hozzá, hogy a magánhasználatra szánt énekeskönyvekben igen kevés ének található, így a 17 egyezés több mint a felét jelenti az énekeskönyvnek. Éppen emiatt a közel 200 éneket tartalmazó 
gyülekezeti énekeskönyvek szükségszerủen több incipitegyezést mutatnak, mint a kisebb számú éneket tartalmazó gyüjtemények. (A textológiai összevetés során értelemszerüen az unitárius magánhasználatra szánt énekeskönyvek variánsai sokkal több azonosságot, mi több, szinte teljes azonosságot mutatnak az RMNy 983. variánsaival, míg az 1593-as bártfai énekeskönyv variánsai például a legritkább esetben tartalmaznak közös eltéréseket az unitárius énekhagyománnyal.) A kéziratos énekgyűjtemények vizsgálata ezek alapján még torzabb képet mutat, ha csupán az incipiteket vizsgáljuk. Néhány olyan gyüjteményt kivéve, mely minden bizonnyal egy gyülekezeti énekeskönyv hivatalosnak mondható, pontos kéziratos leképezése (pl. Csonka antifonálé), a többi gyüjtemény összeállítója, lejegyzője a legtöbb esetben a nyomtatott hagyománytól jelentős mértékben eltérő variánst közöl a gyülekezeti énekekről, mi több, a nyomtatott gyülekezeti énekeskönyvek anyagának töredékét veszi csak be a gyüjteménybe. Az általunk vizsgált kéziratos énekgyüjtemények közül az énekegyezések ellenére egyedül a Csonka antifonálé olyan gyüjtemény, mely szoros, textológiailag is kimutatható kapcsolatban van az unitárius gyülekezeti énekeskönyvekkel. ${ }^{144}$ A szintén unitárius Bölöni-kódex már sokkal kevesebb rokonságot mutat variánsok tekintetében annak ellenére, hogy nagyszámú incipit egyezés figyelhető meg. ${ }^{145}$

Ahogyan azt már az RMKT 17/4.-ben is olvashatjuk, az unitárius gyülekezeti énekvariánsok a leginkább eltérőek az összes felekezet variánsától, ${ }^{146}$ ám egy-egy ének olykor kapcsolatot mutat egy-egy korábbi kiadással, számos saját eltérést hordozva. A variánsokat összevetve sajnos nem mondható ki egy-egy kiadásról, egy-egy felekezeti énekgyüjteményről sem, hogy az képezné az unitárius gyülekezeti énekvariánsok alapját, hogy abból származhatna az unitárius gyüjtemény. Minden valószínűség szerint - mivel az 1602-15 között megjelent gyülekezeti énekeskönyv előttről csupán egy néhány éneket tartalmazó unitárius ima-énekeskönyvről van tudomásunk az 1590-es évekből ${ }^{147}$ - a gyülekezeti énekeket a többi felekezet gyakorlatából ismerték, innen alakultak át, változtak mind a lejegyzés, mind pedig az éneklés alkalmával. Mivel az éneklésről szóló prédikációjában már

\footnotetext{
${ }^{144}$ Ennek az ismertetésére az előző fejezetben került sor.

145 A kéziratos források és az RMNy 983. gyülekezeti énekei az alábbi incipit egyezést mutatják: Csonka antifonálé: 65; Bölöni-kódex: 43; Vasady-kódex: 11; Detsi-kódex: 8; Kassai István énekgyüjteménye: 7; Kuunkódex: 6; Lipcsei-kódex: 5; Balassa-kódex: 2. Itt is jól látható, hogy ha csupán az incipitek egyezését vizsgálnánk, akkor úgy tünne, hogy a református Detsi-kódex szorosabb viszonyban áll az unitárius gyülekezeti énekekkel, mint a kolozsvári lejegyzésü, egyértelmüen unitárius dogmatikával rendelkező Kassai István énekgyüjteményének darabjai. Ez természetesen a szövegösszevetések alapján nem áll fenn.

${ }^{146}$ RMKT 17/4. 527.

147 ENYEDI György, Conciones, közli H. HuBERT, i.m., 379-389. Ebben az 1590-es években keletkezett szövegben említi Enyedi, hogy „,mostan a könyvnyomtató egy néhány szép dicséreteket külön kinyomtatott az imádságokkal együtt, kikkel mostan szoktunk élni...” (H. HUBERT i.m. 388.) A prédikációról és az ebben említett énekgyüjteményről a későbbiekben lesz részletesebben szó.
} 
Enyedi György is említi, hogy más felekezetek hogyan, miként énekelnek, így bátran gondolhatunk arra, hogy az unitáriusok ismerték a további protestáns felekezeti énekköltészetet, ${ }^{148} \mathrm{~s}$ a nyomtatott saját anyag megjelenése előtt ebből merítettek, ezt variálták, alakították át. Ahogyan azt az RMKT 17/4. jegyzete is megjegyzi, ${ }^{149}$ az unitárius korpusz területileg is elkülönül a többi protestáns felekezettől, ám az RMKT azon állítása mely szerint a református egyházi énekköltészettel mutat kapcsolatot az unitárius gyülekezeti éneklés, kiegészíthetjük azzal, hogy olykor valóban állni látszik ez a tendencia, de számos szövegváltozat esetében az evangélikus hagyománnyal áll kapcsolatban egy-egy szövegváltozat, így tendenciózus, minden gyülekezeti énekre érvényes kijelentést nem tudunk tenni. Az RMKT a református hagyománnyal való szorosabb kapcsolatot abban látja, hogy az unitáriusok a református énekeket „oly módon vették át, hogy a szerintük dogmatikailag kifogásolható strófákat elhagyták vagy átalakitották." ${ }^{150}$ Valóban igen erős átalakításokat végeznek a dogmatikailag problémás részek esetében, s ezzel a dolgozat egy kisebb fejezete foglalkozik is, ám ez az átalakítás nem csupán a református szöveghagyományhoz képest más, hanem eltér az evangélikus hagyománytól is. A dolgozat külön fejezetben igyekszik ugyanakkor bemutatni, hogy a szövegváltozások okai messze nem írhatók le csupán a dogmatikai különbözőséggel. Az unitárius hagyomány szövegei számos olyan ponton is eltérést mutatnak a többi protestáns felekezettől, amelynek nincs köze a dogmatikához. Nem árt itt figyelembe venni, hogy a református és az evangélikus énekgyüjtemények variánsai is számos ponton különböznek egymástól. Mi több, ahogyan arra a későbbiekben igyekszünk rámutatni, olykor egy felekezeten belül is megjelennek variánsok az egyes kiadásokban, hiszen a szöveg folyamatosan változik, feltehetően az éneklés, az énekeltségben létezés miatt. A nyomtatott hagyomány az énekelt szövegeket rögzíteni, állandósítani igyekszik, s mediális sajátosságánál fogva a nyomtatott variánsok szövege állandóbb, de olykor egy-egy felekezeten belül is látszik, hogy a gyülekezeti ének nem egy állandó szöveggel, hanem variánsaiban létezett. Különösen látható ez a kéziratos énekgyüjteményekben.

A gyülekezeti éneknek erre a sajátos müfaji jellegzetességére, melyet a dolgozat igyekszik majd példákon bemutatni, többen felhívják a figyelmet.

H. Hubert Gabriella a gyülekezeti énekről, a gyülekezeti ének műfaji sajátosságairól a következőket állapítja meg:

148 „Ezt cselekedik [t.i. a templomban a pappal és a kántorral együtt énekelnek és imádkoznak] másutt is a jól rendelt eklézsiákban, a keresztények ne szégyenljék tanulni és követni a jót." (Szöveggközlés: H. HUBERT, i.m., 388.)

${ }^{149}$ RMKT 17/4. 527.

${ }^{150}$ RMKT 17/4. 527. 
„A gyülekezeti ének fogalma egyrészt olyan anyanyelvü, protestáns népéneket jelöl, amelyet az egész gyülekezet énekel a templomi istentiszteleten, másrészt olyan egyszólamú dallammal ellátott strofikus költeményt, amelyet a protestáns gyülekezetek bizonyos szabályozott módon használnak. Közköltészeti müfaj: népnyelvü; a szerzök sokszor névtelenek; elvileg mindenki, nemre és foglalkozásra való tekintet nélkül énekel a gyülekezetben; az énekek nyomtatott és kéziratos formában, valamint szóbelileg terjednek; mindenhol és minden alkalommal éneklik öket."

A gyülekezeti éneket a $\mathrm{H}$. Hubert Gabriella által is kifejtett müfaji sajátosságai miatt szintén közköltészet alkotásnak mondja a Régi Magyar Költők Tára XVIII. századi sorozatának a közköltészetet tárgyaló 1 . kötetében Küllős Imola. ${ }^{152}$ A bevezetőben a szerző kifejti, hogy „a közköltészeti hagyománynak a vallásos énekanyag éppúgy része, mint a világi”, ${ }^{153}$ ám az egyházi gyüjteményekkel a kötet az anyag mennyisége miatt nem foglalkozik.

Csörsz Rumen István az elméleti megfogalmazáson túl - miszerint a gyülekezeti ének, mi több, az egyházi ének általában véve közköltészeti műfajként fogható fel annak műfaji sajátossága, jellemző hordozói miatt ${ }^{154}$ - konkrét példával szemlélteti azt, hogy egy vallásos énekből hogyan lesz széles körben elterjedt, a bujdosó-témát feldolgozó alkotás, mely gyakorlatilag minden felekezet számára ismert, énekelt szöveggé válik. ${ }^{155}$

Valóban, a gyülekezeti énekek az általunk tárgyalt 118 ének alapján is többségében olyan variabilitást, változási tendenciát hordoznak, amely a közköltészet felé közelíti az egyes énekeket. Noha nem mutatnak akkora variabilitást, mint a 18. század világi darabjai, ${ }^{156}$ ám megfigyelhető az előzőekben már említett mediális sajátosság, amely a nyomtatványkéziratos terjedés-szóbeli (pontosabban énekelt) hagyomány hármas dimenziójában mozog.

A következőkben először igyekszünk bemutatni, hogy a nyomtatott gyülekezeti énekhagyomány apparátuskészlete (szerkezet, címadási szokások, nótajelzési tendenciák stb.)

${ }^{151}$ H. HUBERT Gabriella, 1602: Megjelenik Újfalvi Imre énekeskönyve = A magyar irodalom történetei, A kezdetektöl 1880-ig, szerk. JANKOVITS László, ORLOVSZKY Géza, Bp., Gondolat Kiadó, 2007, 388.

${ }^{152}$ Régi Magyar Költök Tára XVIII. század, IV. kötet, Közöltészet, 1. Mulattatók, s.a.r. KüLlös Imola, munkatárs CsÖRSZ Rumen István, Bp., Balassi, 2000, 31.

${ }^{153}$ RMKT 18/4, 31.

${ }^{154}$ CSÖRSZ Rumen István, Közköltészet - irodalom alatt, kultúrák fölött, Literatura, 2006. 2. 32. évf. $273-282$. (277.)

${ }^{155}$ CSÖRSZ Rumen István, Rákóczi halála nagypénteken - Mikestöl a közköltészetig = Író a számüzetésben: Mikes Kelemen, szerk. TÜSKÉs Gábor, munkatársak: CSÖRSZ Rumen István, HEGEDÜs Béla, LENGYEL Réka, Bp., Universitas, 2012, 226-236 (Historia Litteraria 28).

${ }^{156}$ Ezt mutatja be részletesen CsÖRSZ Rumen István, Szöveg szöveg hátán, A magyar költészet variációs rendszere 1700 - 1840, Bp., Argumentum, 2009 (Irodalomtörténeti füzetek 165). 
milyen változáson mennek át a 17. század elejéig, s ezek a változások miként szolgálják az alapvetően az énekeltségben, a hangzó szövegben létező szövegek könnyebb használatát.

A dolgozat az apparátuskészletek változásának bemutatása után igyekszik néhány olyan szövegváltozási tendenciát ismertetni, amely a gyülekezeti énekhagyománynak ezt a sajátos, a közköltészethez közelítő, de azzal nem teljesen azonosítható voltát támasztja alá. (Akrosztichon és kolofonhasználat ill. kikopás, a szövegek egyszerűsödése, parafrazeálása, az értelemváltozások, a kollektivizáció jelensége, a strófák kikopása vagy épp a strófaszám bővülése stb.)

Noha - ahogyan azt már említettük - vannak szövegek, amelyek nem mutatják az ilyen jellegü variabilitást, a legtöbb általunk vizsgált gyülekezeti ének legalábbis felekezetenként, vagy néhány felekezeten belüli kiadás alatt változik, alakul, variálódik. A dolgozat következő fejezeteiben erről lesz szó.

\section{A szövegváltozatok jellemzése}

A következő fejezetekben ismertetni szeretnénk a protestáns gyülekezeti énekek szövegváltozatainak egymástól való eltérését, s az eltérések lehetséges okait. Kiindulópontunk továbbra is az 1602-15 között keletkezett kolozsvári unitárius énekeskönyv, ${ }^{157} \mathrm{~s}$ az ebben található gyülekezeti énekeknek azon korpusza áll figyelmünk középpontjában, amelynek szövegváltozatai megtalálhatók a további protestáns gyüjteményekben.

Mint már többször említettük, kétségtelen, hogy az unitárius korpusz tér el leginkább a többi protestáns felekezet énekanyagától, ugyanis az első unitárius gyülekezeti énekeskönyv 118 énekéből 45 ének csak az unitárius nyomtatott és kéziratos gyüjteményekben, (esetleg szombatos kéziratos gyüjteményekben) található meg. Az 1602-15-ös kolozsvári énekeskönyv zsoltár és egyéb énekrésze összesen 73 zsoltárparafrázist tartalmaz, s 45 egyéb ének, könyörgés, hálaadás vagy dicséret található még benne. Egyéb énekek alatt azt értjük, amelyek sem a címükben, sem a szövegükben nem tartalmaznak zsoltárszámozásra, zsoltárra utaló megnevezéseket, tehát nem zsoltárból eredő gyülekezeti énekek.

${ }^{157}$ RMNy 983. 
A 73 zsoltárból 33 csak unitárius (és szombatos) környezetben hagyományozódik. Ezek főként Jan Kochanowski zsoltárparafrázisainak fordításai, Bogáti Fazakas-zsoltárok, és ismeretlen szerzőjü énekek.

A 45 egyéb énekből 12 olyan, amely csak unitárius környezetben található meg a 17. század első harmadában. A dolgozat ezeknek a szövegeknek a sajátosságait a későbbiekben még tárgyalja, a jelen fejezetek viszont azzal a 73 szöveggel foglalkoznak, amelyek a protestáns énekhagyományban a 17. század elejéig másutt is megjelennek: tehát a 40 zsoltárral és 33 egyéb énekkel.

Az összevetések során kimutathatóvá vált, hogy a templomban, közösen énekelt szövegek, a gyülekezeti énekek a nyomtatott és kéziratos forrásokban is tartalmaznak olyan jellegzetességeket, amelyek a hangzó, változó, az énekeltségnek alávetett létmód sajátjai. A következő fejezetek ezeket a jegyeket igyekeznek bemutatni és típusokba rendezni. Ennek során vizsgáljuk a folyamat kibontakozását, de azt is, hogy a gondos szerkesztői kezek akadályt is gördítenek a szövegek teljes elburjánzása, a szó szoros értelmében vett közköltészeti alkotássá válása elé. Figyelni igyekszünk ennek során a nyomtatásban és kéziratosságban létezés eltéréseire is, hiszen ez utóbbi esetben jóval több, a közköltészetre is jellemző változást találunk a változatokban. Stoll Béla ${ }^{158}$ a 17. századi kéziratos szerelmi líra hagyományozódása, a fennmaradt variánsok kapcsán megjegyzi, hogy „a szövegváltozatok közötti eltérések néha oly nagyok, hogy azokat semmiképpen sem lehet a kéziratos terjedéssel magyarázni." ${ }^{159}$ Orális, szóbeli és/vagy énekelt hagyományt kell feltételezni ahhoz, hogy a szövegváltozatok eltéréseire magyarázatot adjunk. A szerelmi lírára tett megfigyelését a gyülekezeti énekek kapcsán is érvényesnek mondhatjuk: a kéziratos hagyományozódás sokkal több eltérést tartalmaz minden egyes nyomtatott kiadáshoz képest, aminek az oka nyilván az, hogy a kéziratos énekgyűjtemény készítője akár saját magának, akár egy gyülekezet számára készítette is azt, a nyomtatott hagyományon túl a saját gyülekezetében, élőszóban elhangzó hagyományt is belevette a saját változatába.

A következőkben megvizsgáljuk az énekek címét érintő változásokat az egyes kiadások és kéziratos források tekintetében. A címváltoztatások alatt értjük a zsoltárok számozásbeli eltérésének, de a címben található müfajok, alkalmak vagy funkciók változásának vizsgálatát is.

\footnotetext{
158 STOLl Béla, Közösségi költészet - népköltészet. Megjegyzések a XVII.[A kiadásban félrenyomva 18.-ra] századi kéziratos szerelmi lírához, ItK, 1958. 2-3./170-176.

${ }^{159}$ STOLL, i.m., 171.
} 
A címadási szokások után a nótajelzésbeli változásokra, majd a rím- és ritmusbeli eltérésekre is kitérünk. A szövegek közösségi voltát a 16. század végétől több énekgyüjtemény is előtérbe helyezi, így nem tekinthetünk el a közösségi funkciók megjelenésének tanulmányozásától sem. A konkrétan a verses szövegek változását érintő vizsgálatok alapja pedig elsősorban poétikai jellegü, s az értelemváltozások, szövegromlások, ritmus és rímbeli változtatások lesznek a tárgyai. Az unitárius énekgyüjtemények esetében értelemszerüen megjelenő dogmatikai változásokkal külön fejezetben foglalkozunk. Egy vagy több strófa kiiktatása vagy betoldása, az akrosztichonok változása és a trópusok megváltozásai szintén a közköltészet felé haladó szövegek sajátjai, így azokról is szó esik.

\section{I. A gyülekezeti énekhagyomány apparátuskészletének, paratextusainak változásai}

\section{I. 1. Címváltozások, címadási jellemzők}

\section{I. 1. 1. A zsoltárszámozás a protestáns énekeskönyvekben}

Jóllehet a gyülekezeti ének olyan müfaj, amely a templomban, a gyülekezet által közösen énekelve hangzott el, vannak az írott, nyomtatott változatoknak olyan jegyei is, amelyek élőszóban nem hangoztak, nem hangozhattak el. Ilyen, csak az írott médiumban megjelenő tulajdonsága a gyülekezeti éneknek a címe, az énekeskönyvben betöltött helye, esetleg a szerzője és a nótajelzése. Latzkovits Miklós éppen ezért nevezi a drámák nyomán ezeket a jegyeket a zsoltárok számozását vizsgálva olyan apparátuskészletnek, ${ }^{160}$ melyek a szöveghez tartoznak, de az elöadásban, jelen esetben az éneklés során nem részei azoknak. Mindezek alapján azt gondolhatnánk, hogy a szöveget kísérő apparátuskészlet nem változik annyira, mint az élőszóban elhangzó szövegek maguk, hiszen a címek, a zsoltárok számozása ilyen módon „nincs kitéve” az éneklés, az élőszó következményeképp bekövetkező változásoknak. Másfelől azonban Latzkovits is szemlélteti, hogy a 16. századi protestáns énekeskönyv-kiadások esetében a zsoltárok számozása igen változó, s ennek hozadékaként a zsoltárszámra hivatkozó strófák is gyakran változnak: a zsoltárszám átírása ritmusbeli, rímbeli rontást, olykor javítást is eredményez. ${ }^{161}$

\footnotetext{
${ }^{160}$ LATZKOVITs Miklós, Régi magyar dráma és szöveghagyomány, PhD értekezés, Szeged, 1997, 152.

${ }^{161}$ LATZKOVITS, i.m., 152-190.
} 
Latzkovits - dolgozata témájából adódóan - elsősorban a 16. század második harmadával foglalkozik, tehát föként az 1560 -as óvári, ${ }^{162}$ az 1569 -es debreceni ${ }^{163}$ és az 1574 es komjáti ${ }^{164}$ énekeskönyvekkel. Schulek Tibor ${ }^{165}$ nyomán kifejti, hogy ebben a korszakban énekeskönyv elsősorban a lelkész a kántor kezében volt, s utóbbi énekelte elő a gyülekezet számára az énekeket soronként. ${ }^{166}$ Éppen ezért - mivel a gyülekezet kezében nem volt, vagy alig volt énekeskönyv, a zsoltárok száma, a címe és a nótajelzés csak a kántor számára volt fontos információ. Ennek ellenére jól kivehető az a tendencia, ahogyan az énekeskönyvek szerkesztői igyekeztek a Vulgata-féle, katolikus számozást megváltoztatni, s a korai protestáns kiadások által még a régi zsoltárrend szerint közölt szövegekbe is belenyúlni, hogy a hivatkozásstrófákban is a protestáns számozás legyen alkalmazható.

Mint azt említettük, az általunk elemzett 118 ének között 73 zsoltárparafázis található. Ebből a 73 énekből 33 csak unitárius (és szombatos) ${ }^{167}$ környezetben jelenik meg. A későbbi fejezetek még részletezik, de már itt érdemes megjegyezni, hogy annak ellenére, hogy az unitáriusoknak Bogáti Fazakas Miklós 150 zsoltára a rendelkezésükre állt, az 1602-15-ös kolozsvári unitárius énekeskönyvben ${ }^{168}$ szereplő 73 zsoltár összesen 57 zsoltárnak a parafrázisa. Ezek megoszlásáról részletesen a későbbiekben lesz szó.

Le kell szögezni, hogy az unitárius korpuszon belül a zsoltárszámozások nem változnak, így a csak unitárius (és szombatos) környezetben hagyományozódó szövegek zsoltárai mindig azonos számmal vannak ellátva, s a zsoltárszámozás minden esetben következetesen a protestáns számozás szerint alakul. A további, a protestáns hagyományból az unitáriusba kerülő zsoltárokat tekintve is csak egy olyat találunk, amelynek a számozása nem a protestáns hagyományt, hanem a Vulgatáét követi az unitárius hagyományban, függetlenül attól, hogy a többi forrásban mi áll. ${ }^{169}$ Az unitárius kiadások olyannyira követik a protestáns zsoltárszámozást, hogy gyakran, a többi énekeskönyvben is szereplő szövegeknél inkább elrontják a hivatkozó strófa metrumát vagy rímelését annak érdekében, hogy a számozás pontos legyen. Az Aki veti segedelmét... (90=91. zsoltár, RPHA 74) például

\footnotetext{
162 RMNy 160.

${ }^{163}$ RMNy 264.

${ }^{164}$ RMNy 353.

${ }^{165}$ SCHULEK Tibor, Kísérôtanulmány, BHA IX. kötete, Budapest, 1975. 7.

${ }^{166}$ LATZKOVITS, i.m., 152.

${ }^{167}$ Illetve egy esetben az 1602-es debreceni énekeskönyv (RMNy 886) is tartalmaz egy Bogáti Fazakas- zsoltárt, amikről a későbbiekben lesz még szó, ám ennek a címbeli számozása, a hivatkozó strófája is azonos az unitárius számozással.

${ }^{168}$ RMNy 983.

${ }^{169}$ Ez Az Izraelnek népe régenten... (RPHA 142) incipitű ének, amely a 73 zsoltár közül, melyet az RMNy 983 tartalmaz, egyedüliként követi a Vulgata számozását, de azt a számozást a címen kívül a hivatkozó strófában is megtartja minden unitárius forrás.
} 
minden nyomtatott unitárius forrásban megtalálható, tehát megvan az 1602-15-ös gyülekezeti énekeskönyvben, az 1623-as és az 1635 -ös ${ }^{170}$ magánhasználatra szánt kiadásokban - az utóbbi makulatúrán az utolsó strófa kivételével olvasható - az 1632-es ${ }^{171}$ és az $1697-$ es $^{172}$ kiadású gyülekezetiben, és az 1700 -as ${ }^{173}$ kiadású magánhasználatra szánt énekeskönyvben. A címben az unitárius forrásokon, az 1602-es debreceni kiadáson (RMNy 886) és az 1602-14 közötti bártfai énekeskönyvön kívül (RMNy 965) mindenütt a Vulgata száma szerepel, tehát csak ezek beszélnek a 91. zsoltárról. Ennek ellenére, noha az unitárius szöveghagyomány e zsoltárnál nem követi sem az 1602-es debreceni ${ }^{174}$ kiadást, sem az 1602-14 között kiadott bártfait, ${ }^{175}$ a hivatkozó strófáikban mégis mind a három forrás elrontja a ritmust annak érdekében, hogy a „kilencven” „kilencvenegyre” változzon.

Sőt, az unitárius kiadások az Úrnak szolgái, no dicsérjétek... kezdetű éneket (133=134. zsoltár, RPHA 1447) inkább az egyéb énekek között hozzák, zsoltárszám feltüntetése nélkül, s ez a parafrázis minden más protestáns énekeskönyvben a Vulgata szerinti számozással jelent meg. Ez az ének nem tartalmaz hivatkozó strófát, és az unitárius kiadások a záró doxológiát is kiveszik belőle, amely a Szentháromságot dicsőíti. Az ének az 1560-as ${ }^{176}$ óvári, az 1566 -os váradi, ${ }^{177}$ az 1574 -es komjáti, ${ }^{178}$ és az 1582 -es detrekői ${ }^{179}$ kiadásokban $\mathrm{Az}$ Istennek dicséretére való intés a 134. psalmusból $l^{180}$ címmel jelenik meg. A debreceni református kiadások $\left(1569,{ }^{181} 1570,{ }^{182} 1579,{ }^{183} 1590^{184}\right)$ és az 1593 -as bártfai kiadás ${ }^{185}$ minden esetben zsoltárként határozzák meg, a címe: Psalmus 134. Az unitárius nyomtatványok közül mindegyikben megtalálható, a gyülekezeti énekeskönyvekben és a magánhasználatra szántakban is. (Mivel az 1623-as kolozsvári elveszett ima-énekeskönyv ${ }^{186}$ incipitjegyzékében ${ }^{187}$ szerepel, és az 1700 -as ${ }^{188}$ kolozsvári magánhasználatra szánt kiadásban

\footnotetext{
${ }^{170}$ RMNy 1615.

${ }^{171}$ RMNy 1541.

${ }^{172}$ RMK I. 1503.

${ }^{173}$ RMK I. 1558.

${ }^{174}$ RMNy 886.

175 RMNy 965.

${ }^{176}$ RMNy 160.

${ }^{177}$ RMNy 222.

${ }^{178}$ RMNy 353.

${ }^{179}$ RMNy 513.

${ }^{180}$ A cím az 1560-as és az 1566-os kiadásban van így, ennek közeli változata az 1574-es és az 1582-es kiadás: Az Úristennek dicséretire való intés a 134. psalmusból.

${ }^{181}$ RMNy 264.

182 RMNy 276.

${ }^{183}$ RMNy 429.

${ }^{184}$ RMNy 640.

${ }^{185}$ RMNy 713.

186 RMNy 1290.

${ }^{187}$ ld. VÁRFALVI, KerMagv, 1871, 123-24.

${ }^{188}$ RMK. I. 1558.
} 
is megvan még, így minden bizonnyal benne lehetett a két magánhasználatra szánt kiadás között 1635-ben megjelent ima-énekeskönyvben ${ }^{189}$ is.) Mint említettük, az unitárius gyülekezeti énekeskönyvekben az egyéb énekek között található, nem a zsoltárok között. Az 1602-15-ös kolozsvári gyülekezeti énekeskönyv ${ }^{190}$ Prédikáció után, az 1632-es kolozsvári (RMNy 1541) és az 1697-es kolozsvári gyülekezeti énekeskönyv (RMK I. 1503) Alia címmel hozza. A magánhasználatra szánt énekeskönyvekből csak az 1700-as kolozsvári kiadás címét ismerjük, ez Isteni szolgálatra intő dicséret. Látható, hogy ez a cím közel áll a korai protestáns kiadások címéhez, de nem tartalmazza azt az információt, hogy a Vulgata 134. zsoltára alapján készült.

Mivel az unitárius forrásokban a Vulgata számozása 73 esetből csak egyszer jelenik meg, így a csak unitárius forrásban található szövegek vizsgálatától - mivel ott mindig következetesen a protestáns számozás van használva - a zsoltárszámozás szempontjából eltekinthetünk. Ezáltal a 73 vizsgált zsoltárból 40 marad, amelyet alaposabban meg kell néznünk.

A 40 zsoltárból 14 esetében ${ }^{191}$ találkozunk a protestáns énekeskönyv-hagyományban eltérő zsoltárszámozással, illetve eltérő hivatkozó strófákkal. Ezek közül öt ${ }^{192}$ zsoltárparafrázist már Latzkovits említett munkája is elemzett 1574-ig, elsősorban abból a szempontból, hogy a Vulgata-féle számozást hogyan próbálják eltüntetni, módosítani az egyes kiadások.

A Keresztyéneknek Istene... kezdetű parafrázis ${ }^{193}$ (79=80. zsoltár, RPHA 732) kapcsán Latzkovits ${ }^{194}$ felhívja arra a figyelmet, hogy a zsoltár nem tartalmaz hivatkozó strófát, ám 1574-ig ennek ellenére a Vulgata szerint, 79. zsoltár címmel jelenik meg. (Az 1560-as óvári kiadásban ${ }^{195}$ 79. psalmus a cím, az 1566-os váradiban ${ }^{196}$ félrenyomtatva 71 . a cím. ${ }^{197}$ ) E két

\footnotetext{
${ }^{189}$ RMNy 1615.

${ }^{190}$ RMNy 983.

191 Aki az istent megismerheti... (RPHA 68), Jer, emlékezzünk, keresztyén népek... (RPHA 645), Keresztyéneknek Istene, te vagy... (RPHA 732), Hallgasd meg, Atya Isten, a mi szükségünket... (RPHA 492), Nagy bánatban Dávid mikoron vala... (RPHA 1024), Boldog az ilyen ember... (RPHA 119), Dávid prófétának imádkozásáról... (RPHA 242), Hogy panaszolkodik a hatalmas Isten... (RPHA 550), Aki veti segedelmét az Istennek... (RPHA 74), Az Izraelnek népe régenten... (RPHA 142), Mindenek meghallják és jól megtanulják... (RPHA 0968), Minden állat dicsér... (RPHA 0952), Nagy hálaadással magasztallak téged, én Istenem... (RPHA 1031), Dicsérd az Istent mostan, ó én lelkem...(RPHA 251).

${ }_{192}$ Keresztyéneknek Istene... (RPHA 732), Jer, emlékezzünk, keresztyén népek... (RPHA 645), Aki az istent megismerheti... (RPHA 68), Hallgasd meg, Atya Isten... (RPHA 492), Nagy bánatban Dávid... (RPHA 1024)

${ }^{193}$ A 79. zsoltár 16. századi magyar parafrázisait összefoglalóan elemzi: IMRE Mihály, ,,Magyarország panasza” A Querela Hungariae toposz a XVI-XVII. század irodalmában, Debrecen, Kossuth Kiadó, 1995, 199- 212 (Csokonai Könyvtár 5). Ennek a gyülekezeti énekként használt énekversnek az elemzésénél Imre Mihály kitér arra, hogy a magyar parafrázisok jellemzően kevésbé aktualizáltak, a törtökre vonatkoztatottak, mint német társaik.

${ }^{194}$ LATZKOVITS, i.m. 162.

${ }^{195}$ RMNy 160.
} 
kiadás a Vulgata 79. psalmusának latin incipitét is hozza a cím után: Qui regis Israel intende etc. Az $1569-$ es $^{198}$ és az 1570 -es ${ }^{199}$ debreceni kiadások már latin incipit nélkül, de 79. zsoltárként hozzák. Először az 1574-es komjáti ${ }^{200}$ kiadás hozza 80 . zsoltár címmel, a latin incipitet meghagyva. Latzkovits megfigyeléseihez hozzátehetjük, hogy innentől már minden, általunk vizsgált debreceni és bártfai kiadás, illetve az 1582-es detrekői kiadás ${ }^{201}$ is 80 . zsoltár címen hozza. (Az 1579-es debreceni ${ }^{202}$ kiadás egész egyszerűen Psalmus címmel.) Az, hogy egészen 1574-ig nem változtattak a Vulgata számozásán, holott megtehették volna egyszerúen a hivatkozó strófa hiánya miatt, arra utal, hogy talán a protestáns számozás bevezetése - bár fontos volt, erre általában igyekezetek odafigyelni - a gyülekezeti énekeskönyvek tekintetében mégsem elsődleges fontosságú, mert az apparátuskészlet elsősorban a kántornak készül, s a címet nem olvassa fel a kántor a gyülekezet számára. Ahogyan azt majd a későbbiekben látni fogjuk, az unitárius énekeskönyvek megjelenésének idejére már a gyülekezet egyre több tagja tart a kezében énekeskönyvet, s így - a későbbiekben részletezett módon - az apparátuskészlet átalakítására, egyszerüsítésére is szükség van. Ezzel összefügghet az a tény, hogy a zsoltárszámok címbeli elhagyása csak a nyomtatott unitárius, illetve a kéziratos anyagban figyelhető meg, s emellett az unitárius gyülekezeti énekeskönyv dolgozik a legegyszerübb szerkesztési móddal, az ábécés szerkesztési elvvel. Talán éppen ez az oka annak, hogy az unitárius kiadások nem is illetik már zsoltárszámmal ezt az éneket sem, az 1602-15 közötti kolozsvári kiadás Más ének, az 1632-es kolozsvári pedig Más „címmel,” illetve elválasztó funkciójú szóval látja el.

Az Aki az Istent megismerheti... (102=103. zsoltár RPHA 68) esetében Latzkovits Miklós megállapítja, hogy „a záró strófákat Huszár Gál egészen más, kisebb betütípussal szedi, mint a psalmusok szövegét. „Mintha csak arra kívánná felhívni a figyelmet, hogy ezen versrészletek a zsoltártestnek nem képezik olyan szerves részét, mint az elözö versszakok."203 Ez a zsoltár a korszak szinte minden protestáns énekeskönyvében megtalálható, s az 1602-es debreceni, Újfalvi-féle kiadást kivéve mindenütt a protestáns számozás szerint van meg, tehát 103. zsoltárként. Újfalvi Imre 102. psalmus címmel illeti. Azt is meg kell jegyezni, hogy a Latzkovits által említett záró strófa nem tartalmaz a zsoltárra, annak számára utaló adatot,

\footnotetext{
${ }^{196}$ RMNy 222.

197 A félrenyomás egészen bizonyos, mivel a Vulgata 79. latin kezdősora ugyanúgy szerepel a cím után, mint az 1560-as óvári kiadásban.

${ }^{198}$ RMNy 264.

199 RMNy 276.

${ }^{200}$ RMNy 353.

${ }^{201}$ RMNy 513.

${ }^{202}$ RMNy 429.

${ }^{203}$ LATZKOVITS, i.m., 171-172.
} 
hanem a klasszikus értelemben vett kolofonnal találkozunk a szövegben: a szereztetés célját és idejét találjuk meg benne.

Egyetértve Latzkovits Miklóssal azt mondhatjuk, hogy úgy tünik, a kolofonok, a szereztetés helye és ideje, körülményei a gyülekezeti éneklés számára mellékesnek tekinthetők, így nem kizárt, hogy az 1560-as óvári ${ }^{204}$ kiadásban éppen azért szerepel kurzívval szedve, hogy elkülönüljön a többi, éneklendő szövegrésztől. Ez a zsoltárparafrázis kiváló példája annak, hogy az egyes szövegek az idők során hogyan válnak nyomtatott, fixált szövegekböl, melyeket néha énekelnek, olyanná, amelyet elsődlegesen már énekelve használnak, s annak írásbeli, nyomtatott rögzítése már csak az oralitásban való elhangzás segédeszköze lesz. ${ }^{205}$

A klasszikus értelemben vett kolofonstrófa megvan az 1560-as óvári mellett az 1566os váradi, az 1569-es, az 1570-es, az 1579-es, és az 1590-es debreceni kiadásokban, valamint az 1574-es komjátiban és az 1593-as bártfai kiadásban is: ${ }^{206}$

\section{Ezt mostan szerzék, Istent dicsérék, sok jóvoltában ötet megismerék, keresztyén népet ezekre inték, az ezerötszáz negyvennyolcban szerzék.}

Érthető, hogy a gyülekezetben nem szükséges elhangoznia a szerzés időpontjának, így ez a strófa az éneklés szempontjából mellékesnek tekinthető. Sőt, mivel ez - a szerzőség, a szerzői tulajdon szempontjából nyilván fontos adat - elavulttá és a gyülekezet szempontjából mellékessé válik, így a későbbiek folyamán minden szerkesztő igyekszik változtatni ezen a kolofonstrófán.

Legelőször Bornemisza Péter hagyja el a kolofont, s illeszt a helyére egy doxológiát az 1582-es detrekői kiadásban, mégpedig úgy, hogy ezt az a10 a11 a10 a11-es metrumhoz teljesen hozzáigazítja:

\section{Dicséret neked, Atya Úristen, te szent Fiaddal a Jézus Krisztussal, dicséret legyen a szentlélekkel, most és mindenkor, örökkön örökké.}

\footnotetext{
${ }^{204}$ RMNy 160.

${ }^{205}$ Meg kell jegyezni, hogy Újfalvi Imre 1602-es debreceni énekeskönyve lesz az első olyan gyülekezeti énekeskönyv, amely a klasszikus értelemben vett kolofonstrófákat már következetesen, szinte mindenütt el is hagyja.

${ }^{206}$ A kéziratos források közül a Detsi-kódex (S25) is ezt hozza.
} 
A kolofont Újfalvi Imre sem veszi már bele az 1602-es debreceni kiadás variánsába, ám ő nem doxológiát, hanem egy új, a zsoltárszámra hivatkozó strófát illeszt a helyébe, amely viszont az a10 a11 a10 a11-es metrum helyett a11 a11 a10 a12-est hoz, gyakorlatilag teljesen megváltoztatva a többi strófához képest az utolsó ritmusát. Ebből esetleg arra is következtethetünk, hogy ez az utolsó strófa még így, hivatkozó strófaként sem hangzott el énekelve, ám messzemenő tanúságok levonására ez a szemléletes példa nem alkalmas, mert Újfalvi Imre ehhez az énekhez az Irgalmazz, Úristen... (RPHA 590) kezdetű éneket hozza nótajelzésnek, amelynek azonban a12 a12 a12 a12 a metruma.

Újfalvi szövegváltozatában az is figyelemre méltó, hogy a szöveghagyomány során egyedül ő nem használja a címben a protestáns számozást, ugyanis a Vulgata alapján 102. psalmusnak nevezi azt. Ennek ellenére a hivatkozó strófa a 103. zsoltárként nevezi meg a szöveget:

\section{Ebben a szent Dávid Istent dicséré, sok jóvoltában ötet megismeré, \\ keresztyén népet ezekre inté, az száz és harmadik énekében szerzé.}

Noha a metrumot nem tartja a hivatkozó strófa a többi versszak metrumához képest, figyelemre méltó azonban, hogy az 1560-tól forgalomban lévő kolofont minimális változtatással igyekszik hivatkozó strófává változtatni.

Az 1602-15 közötti kolozsvári kiadás és a kéziratos unitárius források közül a Csonka antifonálé nem hozza a kolofonstrófát, de helyette sem hivatkozó strófa, sem doxológia nem található.

Ezzel szemben az 1632-es és az 1697-es unitárius gyülekezeti énekeskönyvekben egy teljesen új, az eddigiektől különböző záró strófa található, hivatkozva a protestáns zsoltárszámozásra. Az új hivatkozó strófa ritmusa is tökéletesen megfelel a parafrázis metrumának, s nótajelzésül a Jer, emlékezzünk, keresztyén népek... kezdetü parafrázist adja (RPHA 645).

Szent Dávid írta az ö könyvében, dicséretinek százharmad részében, ${ }^{207}$ ad ö Istennek hálákat ebben, mikor örvendez az ö Istenében.

207 A Bölöni-kódex záró strófája szinte teljesen azonos az 1632-es és az 1697-es kolozsvári kiadásokéval, egyedül a második sor tér el: száz és harmadik szép dicséretében. Ez abból a szempontból is érdekes, hogy a Bölöni-kódex 1616 és 1621 között keletkezett Háromszéken, ennek ellenére az 1632-es kiadású kolozsvári gyülekezeti énekeskönyv változatával rokonítható a strófa. 
Az unitáriusok által az 1632-es kiadású gyülekezeti énekeskönyv megjelenésétől nótajelzésként hivatkozott Jer, emlékezzünk, keresztyén népek... kezdetü ének (RPHA 645) mind a zsoltárok számozása, mind a hivatkozó strófákban található zsoltárszámok kapcsán érdekes. Ez az ének, illetve az Aki az Istent megismerheti...(RPHA 68) egyébként a protestáns szöveghagyományozódást tekintve mintapéldánynak mondható. Mintaszerúen jelennek meg ezekben ugyanis a közköltészeties jegyek, elsősorban az éneklés során kialakuló variabilitás. Így a későbbiekben ezek a szövegek még többször a szemléltetés eszközei lesznek. A variánsok éppen azért változhattak annyit egymáshoz képest, mert a kolofonok tanúsága szerint a protestáns énekköltészet igen korai darabjairól van szó (a szerzés ideje 1548 és 1549), s minden gyülekezeti énekgyüjteményben megjelennek, a Jer, emlékezzünk... kezdetü a váradi énekeskönyvben kétszer is, de népszerüek a kéziratos énekgyüjteményekben is.

A két ének egyébként az unitárius korpuszban egymást használja nótajelzésnek. A hasonló metrum (a10 a11 a10 a11 az Aki az istent megismerheti... esetében, és x10 x11 x10 x11 a Jer, emlékezzünk, keresztyén népeknél), a kolofon alapján közeli szereztetési dátum, illetve a kolofonok hasonlósága alapján azt sem zárhatjuk ki, hogy a két szöveg szerzője ugyanaz az ismeretlen, korai protestáns szerző.

A Jer, emlékezzünk... a legtöbb esetben a protestáns számozás szerinti címet viseli, tehát 121. Psalmus címmel szerepel. Ezek a következők: az 1560-as óvári, az 1566-os váradi, - ebben a kiadásban kétszer is szerepel, de csak a 94. oldalon kezdődő szöveg címe 121. zsoltár - az 1569-es, 1570-es, 1579-es, az 1590-es és az 1602-es debreceni kiadások, az 1602-14 közötti bártfai énekeskönyv, és a kolozsvári kiadású unitárius gyülekezeti énekeskönyvek (az 1602-15 közötti, az 1632-es és az 1697-es.) Így szerepel még a kéziratos forrásokban is: a Csonka antifonáléban és Kassai István énekgyüjteményében. A Vulgata szerinti számozást követi az 1566-os váradi kiadás 173. oldalán található, a kötetben másodjára közölt, az elsőtől némileg eltérő szövegváltozat, és 120. Psalmus címmel szerepel az 1574-es komjáti énekeskönyvben és az 1582-es detrekői kiadásban is. A zsoltárszámozások szempontjából a vers azért is érdekes, mert az utolsó előtti versszaka hivatkozó strófa. A hivatkozás minden esetben azonos a címben megjelölt zsoltár számával, ám ott, ahol a protestáns számozás szerint, 121. zsoltárként szerepel, minden változat elrontja a metrumot. Minden, a címben 121. zsoltárt használó változat hivatkozó strófájának második sora a 11-es szótagszám helyett 12-t hoz: „,ö levelének százhuszonegy részében, [...]”

A szótagszám kijön a másik három, 120. zsoltár címmel ellátott változat esetében, mert az 1566-os váradi énekeskönyv 173. lapján kezdődő változat a „százhuszad rendiben” formát használja, míg az 1574-es komjáti és az 1582-es detrekői kiadások a „százhuszad 
részében" kifejezést használják. Ebből arra következtethetünk, hogy eredetileg az 1549-ben szerzett éneket az ismeretlen szerző a Vulgata szerinti számozással írta meg, s csak később alakították át azt.

Érdemes azt is megjegyezni, a tendencia, miszerint a kolofonokat egy idő után - nem kizárt, hogy azért is, mert a hangzó szövegnek nem részei - igyekeznek eltüntetni vagy átalakítani, ennek a parafrázisnak a szöveghagyományában is tetten érhető. Jelen esetben a hivatkozó strófa utáni kolofonstrófát (Ezt mostan szerzék, Istent dicsérék,/ kegyelmes voltát neki megismerék,/ segitségében ${ }^{208}$ és jótétében, az ezerötszáz és negyvenkilencben) ${ }^{209}$ elhagyja már az 1566-os váradi kiadás 173. oldalán kezdődő változata is, 1590-es debreceni, az 1602es debreceni, illetve mindhárom unitárius gyülekezeti énekeskönyv is.

Az imént elemzett példából arra következtethetünk, hogy nem feltétlen a kiadás korai voltán múlik, hogy a zsoltárokat a Vulgata alapján, vagy a protestáns módra számozzák. Sokkal inkább attól függ ez, hogy az adott zsoltár mikor keletkezett, illetve hogy mikor kerül be az éneklési gyakorlatba, mikortól ismerik azt. Ha hosszú ideje a Vulgata szerinti számozást éneklik a hivatkozást tartalmazó strófában - amennyiben ezt a strófát énekelték - akkor érthető, hogy olykor miért csúsznak be ismét a régi számozás szerinti sorok, vagy az Úrnak szolgái, no dicsérjétek... esetében miért marad például mindenütt a Vulgata szerinti számozás. Itt talán egy olyan rés nyílik meg, ahol az egyáltalán nem következetes adatok mögött hiszen nem mondható, hogy bármelyik kiadás is következetesen javít, vagy ront el számozást, illetve változtatás nélkül vesz át másik kiadásból minden zsoltárszámot - láthatóvá válik a gyülekezeti énekeknek az a fontos sajátossága, hogy egyrészt énekelt hagyományon, másrészt nyomtatott szövegeken alapulnak. Ma már csak a nyomtatott adatok állnak a rendelkezésünkre, de a nagyszámú forrásösszevetés szemléletesen meg tudja mutatni, hogy a nagyobb közösség, közönség által ismert és énekelt énekszövegek és a kiadói javító szándék hogyan keverednek egymással, hogyan változtatnak meg szövegeket vagy apparátuskészletet az egyes kiadások közötti időszakban.

Mint említettük, az unitárius énekeskönyvek a zsoltárok számozása tekintetében mindig következetesek: minden esetben a protestáns számozást követik, mind a csak unitárius forrásban fennmaradt szövegek, mind a protestáns hagyományból átvett szövegek. ${ }^{210}$ A Hogy panaszolkodik a hatalmas Isten ... kezdetű ének (49=50. zsoltár, RPHA 550) jó példa arra,

\footnotetext{
${ }^{208}$ A legkorábbi, az 1560-as óvári kiadás rossz ritmussal hozza: a „segitségét ebben” kifejezést használja.

209 A kolofon megtalálható az alábbi kiadásokban: 1560 Óvár, 1566 Várad 94. o., 1569 Debrecen, 1570 Debrecen, 1579 Debrecen, 1593 Bártfa, 1602-14 Bártfa.

${ }^{210}$ Ez a következetesség arra is utalhat, hogy az unitáriusok a zsoltároknak különös jelentőséget tulajdonítanak, hiszen a zsoltárfordításban is az élen járnak a protestáns felekezetek között Bogáti Fazakas első teljes zsoltárfordításával, majd Thordai János zsoltáraival.
} 
hogy az unitárius hagyományban mindig a protestáns zsoltárszámok jelennek meg, még akkor is, ha ez másutt nem így van. Minden, általunk tárgyalt nyomtatott énekeskönyvben 50. zsoltár a cím, ${ }^{211} \mathrm{~s}$ ennek ellenére minden kiadás utolsó strófája a 49. zsoltárként nevezi meg a psalmust, kivéve az RMNy 983-at, és a többi unitárius gyülekezeti énekeskönyvet, amelyek már elhagyják a Vulgata-féle számozást. Szintén 50.-nek nevezi az 1602-14 között Bártfán kiadott evangélikus énekeskönyv hivatkozó strófája is, ám más szövegváltozattal. Érdekes módon mind az unitárius, mind az evangélikus kiadás ügyel arra, hogy a metrumnak megfelelően 12 szótagú új sort alkosson. Az utolsó strófa 2. sora a legtöbb esetben „,negyvenkilencedik nagy szép énekében”, amit az unitárius kiadások „az ö ötvenedik nagy szép énekében" változatra cserélnek, az 1602-14 közötti bártfai énekeskönyv szövegváltozata pedig a teljes sort kicseréli: „ő zsoltárának ötvenedik részében”.

A Bölöni-kódex címében Psalmus LI. áll, a hivatkozó strófában pedig a 49. zsoltárról beszél. ${ }^{212}$ A kéziratos forrásokban egyébként igen gyakori, hogy a még egymástól olyannyira eltérő nyomtatott hagyományhoz képest is változásokat tartalmaznak. Ez lehet teljesen más zsoltárszám is, de a legtöbb esetben inkább elhagyják a számot, és Alia, vagy Más áll a szöveg élén, sőt, a Csonka antifonálé igen gyakran inkább cím nélkül hozza a zsoltárokat. ${ }^{213} \mathrm{~A}$ kéziratos énekgyüjteményeknek a zsoltárok esetében következetlen, vagy a zsoltárszámozást elhagyó címadási szokásai is arra utalnak, hogy a kéziratokban, - még ha gondosan másolták is egy nyomtatványról vagy másik kéziratról - nem volt fontos a használó számára az eredetileg a kántornak szánt apparátuskészlet gondos átvétele.

Idővel a gyülekezeti énekeskönyveket egyre kisebb, tehát könnyebben hordozható, a gyülekezet számára is hozzáférhető formában, feltehetően egyre nagyobb példányszámban adták ki. Így a 16. század végére, a 17. század elejére a protestáns felekezetek hívei valószínűleg egyre gyakrabban tartottak otthon, maguknál énekeskönyvet.

Ebből adódik, hogy a kezdetben csak a kántornak, a kórusnak szóló apparátuskészlet látható, olvasható lesz a gyülekezet tagjainak is. A zsoltárszámozásban, a címek követhetőségében, az egyes énekek megtalálásában tehát egyre inkább a mindennapos

\footnotetext{
${ }^{211}$ RMNy 160, RMNy 222, RMNy 264, RMNy 276, RMNy 353, RMNy 429, RMNy 513, RMNy 640, RMNy 713, RMNy 886, RMNy 965, RMNy 983, RMNy 1541, RMK I. 1503.

${ }^{212}$ Ez valószínü, hogy az IL. - LI. elírásból fakadhat.

${ }^{213} \mathrm{Az}$ Unszol/Int most minket Dávid próféta... (RPHA 1417) esetében a mindenütt következetes 117. zsoltár cím, és az elején található hivatkozásstrófa változatlan, 117-es számának ellenére a Csonka antifonálé cím nélkül hozza. A Dicsérem az Urat/Dicsérem én az Istent/Dicsérem az Úristent minden időben... kezdetü (RPHA 254), Dóczi Zsuzsanna nevére írott parafrázis esetében a nyomtatott kiadások (melyek csak unitárius források: az 1602-15 közötti, és az 1632-es kiadású gyülekezeti énekeskönyvek) a 34. zsoltár címet használják, míg a kéziratok közül a Vasady-kódex az akrosztichont használja címként (a Dézsi-hagyaték alapján): DOCI SUSANA. A Lipcsei-kódexben (szintén Dézsi alapján) a Sequitus alia Cantio címet viseli, míg a Lugossy-kódex (S 47) Canticula optima címmel illeti.
} 
használat szempontjából praktikus, letisztult megoldásokat érdemes választania a szerkesztőnek. Talán éppen ez az oka annak is, hogy a 17. századra eltünik - az evangélikus hagyomány kivételével - a többrészes énekeskönyv-szerkezet, s egyre kevesebb részből áll egy gyülekezeti énekeskönyv. Az evangélikusok által 1593-ban Bártfán kiadott énekeskönyv szerkezetéről H. Hubert Gabriella megjegyzi, hogy egyedülálló a 16-17. századi magyar nyelvű darabok között, hiszen az egyházi év ünnepi és ünneptelen félévére van felosztva, s ezen belül az ünnepek között tematikusan szerkesztett rend található. E különös szerkesztési elvnek H. Hubert véleménye szerint német előzményei lehetnek. ${ }^{214}$ Az 1602 és 1614 között Bártfán megjelent evangélikus énekeskönyv is olyan tematikus felosztást használ azonban, amely feltételezhetően ennek a rendszernek az átalakítása. ${ }^{215}$ Ebben olyan szerkezeti csoportokat találunk például, mint a „,mikor ördög és a bün háborgat”, vagy „az emberi élet rövid és bizonytalan voltáról" stb.

A debreceni református kiadások 1602-től, Újfalvi Imre énekeskönyvének megjelenésétől egyszerűbbek, kevesebb szerkezeti részből állnak. Újfalvi zsoltárokra, - ezek szám szerint növekvő rendben vannak a kötetben - ünnepi énekekre, - ezen belül adventtől indulva a Szentháromság napjáig az egyházi ünnepek rendjén haladva osztja fel a gyülekezeti énekeket - káté-énekekre, és „külömb-külömb féle énekekre”216 tagolva a gyülekezeti énekeskönyvet.

Az első unitárius gyülekezeti énekeskönyv - ahogyan ezt már kifejtettük - láthatóan az Újfalvi-féle rendszerezést veszi át, s némileg egyszerüsíti azt, hiszen a gyülekezeti rész az invokációk után az ünnepi énekeket, majd a káté-énekeket hozza, s ezek után következnek az általunk elemzett zsoltárok, majd a különféle énekek. A zsoltárok az első unitárius énekeskönyvben szám szerint növekvő rendben találhatók, mint a református zsoltáros szerkezeti egységek esetében. Az 1632-es unitárius gyülekezeti énekeskönyv a zsoltárokat már ábécérendben közli, s vegyít hozzájuk alkalmi énekeket is, ${ }^{217}$ ugyanúgy, ahogyan különféle énekeket is. Ezt az ábécés szerkesztési rendet használja mind a zsoltárok, mind az egyéb énekek esetében az 1697-es kiadás is. Az 1632-es kiadás a zsoltárok ábécérendje után az egyéb énekeket új ábécérendben, új szerkezeti egységben közli, amelynek a végén kiegészítésként, pótlásként van még néhány zsoltár, újrakezdve az ábécérendet, de nem jelezve ezt külön szerkezeti egységként, ezt követi aztán még egy újrakezdett ábécérend, melyben zsoltárok és egyéb énekek vegyesen találhatók.

\footnotetext{
${ }^{214}$ H. HUBERT, i.m., 139.

${ }^{215}$ H. HUBERT, i.m., 150-51.

${ }^{216}$ ÚJfALVI Imre, Keresztyéni énekek (facsimile, Ács Pál,) BHA XXXVIII. 115.

${ }^{217}$ H. HuBERT Gabriella is ír erről: i.m., 177.
} 
Az unitárius magánhasználatra szánt énekeskönyvek közül ${ }^{218}$ csak az 1700-as kiadású ima-énekeskönyvet tudjuk ma kézbe venni. A fennmaradt adatok fényében ${ }^{219}$ azonban bizonyos, hogy az 1623-as kiadású magánhasználatra szánt énekeskönyvben is ábécérendben voltak az énekek, s az 1635-ös kiadás fennmaradt része is erről tanúskodik. Azt, hogy az 1635-ös kiadás tartalmazott-e pótlást vagy bővítést, sajnos semmiféle fennmaradt adatból nem tudjuk alátámasztani. Bizonyos viszont, hogy az 1700-as kiadás a 80. oldaltól újrakezdett ábécérendjében 36 új ének található, azaz gyakorlatilag megduplázza az 1623-as kiadás énekszámát.

$\mathrm{Az}$ ábécérend szerint szerkesztési elv egyik ismert gyülekezeti és/vagy magánhasználatra szánt énekeskönyvben sem található meg a magyar nyelvű unitárius korpuszon kívül, így némileg magyarázatra szorulhat.

Már H. Hubert Gabriella is megjegyzi, hogy „az egyes énekek könnyebb megtalálását is figyelembe vette a csoportositás." ${ }^{220}$ Valóban úgy tünik, hogy ahogyan a gyülekezeti énekeskönyvek is egyre inkább elérhetővé váltak az emberek számára, úgy vált szükségessé a praktikus szerkesztés, amelyet a hívők gyorsan, egyszerűen használni tudnak. A szerkezeti csoportok csökkentése (gyakorlatilag két csoportra: a zsoltárokra és az egyéb énekekre) és az ábécérend lehetővé teszi a gyülekezet számára az énekeskönyv egyszerü és praktikus használatát. $^{221}$

Úgy tűnik tehát, hogy az ábécérend bevezetése is azzal magyarázható, hogy a gyülekezeti énekeskönyvek összeállítására annak használói is nagy hatással vannak, hiszen ha a praxist nem is ők, hanem a szerkesztők vezetik be, ez a közösségi igény bizonyos mértékben formálja a gyakorlatot. A szövegek variabilitása is, az énekgyüjtemények szerkezete, és az énekekhez tartozó apparátuskészlet is függ tehát valamelyest a gyülekezettől, az énekeskönyvet olvasó, használó közösségtől. Ilyen módon a gyüjtemények használói visszahatnak a gyüjtemények későbbi kiadásaira mind a szerkezet, mind a szövegek esetében. Ez a tény viszont az unitárius címadási szokásoknak a protestáns hagyománytól eltérő módjára is magyarázattal szolgálhat. ${ }^{222}$

\footnotetext{
${ }^{218}$ Ezek közül az RMNy 746-ról, tehát egy valószínűleg megjelent kis méret unitárius énekeskönyvecskéről csak egy Enyedi prédikáció alapján van tudomásunk. Az 1623-as kiadás (RMNy 1290) elveszett, s csak Várfalvi (KerMagv, 1871, 123-24) tanulmányából ismerjük az incipitjegyzékét, az RMNy 1615-ös számú makulatúráról a dolgozat korábban igyekezett bizonyítani, hogy minden bizonnyal egy unitárius magánhasználatra szánt énekeskönyv makulatúrája, s mára már csak az 1700-as kiadás maradt fönn (RMK I. 1558-59).

${ }^{219}$ VÁRFALVI i.m.

${ }^{220}$ H. HUBERT, i.m., 177.

221 A kutatás során igyekeztünk keresni külföldi, főleg német és lengyel példákat, amelyek szintén az ábécérendes szerkesztési elvet használják, de nem találkoztunk hasonlóval.

${ }^{222}$ Az ábécérendes szerkesztési mód magyarázatának esetleges okai közül nem zárható ki a műfajiságot érintő magyarázat sem: a szélesebb körü használattal a műfaji határok is elmosódhatnak, ami szükségtelenné teheti az
} 


\section{I. 1. 2. Az ,egyéb énekek” címadásának hagyománya}

A nem zsoltár típusú énekek tárgyalásakor az unitárius hagyományt némileg külön kell kezelnünk a többi protestáns énekeskönyv címhasználatától. Erre egyrészt az ad okot, hogy jelen dolgozat az unitárius ünnepi énekeket nem tárgyalja ugyan, de vannak olyan énekeskönyvek, amelyekben ezek nem különülnek el a zsoltároktól és egyéb alkalmi énekektől. Ettől a ténytől nem tekinthetünk el, hiszen úgy torz adatokat kaphatnánk. Másrészt, mint már említettük, az unitárius címadás igencsak eltér a többi protestáns felekezetétől. Így a 16. század közepi protestáns címadási hagyományokról néhány tendenciát kirajzoló észrevételt leginkább Hubert Gabriella 1989-es tanulmánya alapján tehetünk. ${ }^{223}$ Ahogyan azt az RPHA munkálatai alapján Hubert kiemeli, ${ }^{224}$ fontosak a címekből kinyerhető önreflexív jellegü adatok, hiszen ezáltal lehetséges megértenünk a 16-17. században kialakuló, alakuló, változó müfaji jellegű megnevezéseket. Ahhoz, hogy megértsük az épp csak formálódó magyar nyelvű poétikai terminusokat, a címekben, fejlécekben található kifejezéseket regisztrálnunk kell. ${ }^{225}$ A történeti-poétikai vizsgálatok azt mutatják, - ahogyan arra a tanulmány is rávilágít, - ${ }^{226}$ hogy a 16. században a legtöbb esetben az úzus és a téma megjelölése szerepel a címekben. Tehát a használat, az alkalom, és az adott ének témája lesz a meghatározó a legtöbb cím és fejléc esetében. Hubert Gabriella tanulmánya ezek alapján osztja fel a gyülekezeti énekeskönyvek énekeit ünnepi, a hét napjaira és napszakokra szánt, istentiszteleti, katolikus eredetü liturgikus énekekre, protestáns tanítást és dogmát tartalmazókra, alkalmi énekekre, illetve kitér a tartalmi besorolásokra is. Mint említettük, a vizsgált unitárius énekek címadási és szerkezetbeli eljárásai nem adnak lehetőséget arra, hogy ezekbe a kategóriákba beillesszük azokat. A további protestáns felekezetek énekeskönyv-

énekeskönyvek szerkezeti felosztását. Ezt az érvelést azonban csak akkor érdemes kifejteni, ha nagyobb számú anyagon is vizsgálatot tudunk végezni, például az RPHA 17 elkészültével. Az RPHA 17 tárgyalja a műfajt érintő önreflexiókat is, s emellett külön adatsorban elemzi a müfaji összetevőket, így reményeink szerint lehetővé teszi majd az ilyen irányú kutatásokat is.

${ }^{223}$ HuBERT Gabriella, Gyülekezeti énekek müfaja: van-e rendszert az adatokban?, ItK, 1989, 298-305.

${ }^{224}$ HUBERT, i.m., 1989, 299.

${ }^{225}$ A 17. századi magyar vers adatbázisában mi is erre törekszünk: az önreflexiók kigyüjtésével a célunk, hogy létrehozzuk a magyar nyelvü poétikai- és müfaji terminus technikusok szótárát. Az RPHA 17. adatainak, struktúrájának ismertetésére jelen dolgozat keretei között nincs mód, erről bővebben pl.: BALÁzS-HAJDU Péter BOGNÁR Péter - HEVESI Andrea - SinKA Zsófia, Szegedi kísérlet a 17. századi magyar vers gépi feldolgozására, Filológia és Textológia a régi magyar irodalomban (konferenciakötet), szerk. KECSKEMÉTI Gábor, TASI Réka, Miskolci Egyetem BTK, Magyar Nyelv- és Irodalomtudományi Intézet, Miskolc, 2012, 461-470.

${ }^{226}$ HUBERT 1989, 299. 
kiadási szokásainál azonban az tendencia-szerűen észlelhető, hogy a címek és az énekek helye kevésbé változó, mint az unitáriusok esetében. Jellemző, hogy címek tekintetében az 1560-as óvári kiadást követi minimális változtatással az 1566-os váradi, de számos esetben az 1574-es és az 1582-es detrekői kiadás is. Az 1569-es debreceni kiadások alapvetően nem változtatnak, vagy minimálisan változtatnak az énekek címein a korai protestáns kiadásokhoz képest, viszont az 1569-es kiadáshoz képest a többi debreceni kiadás már gyakran rövidít, egyszerüsít a címeken. Az Adjunk hálát mindnyájan az Atya Úristennek... kezdetü ének (RPHA 62) például az 1569-es debreceni kiadásban még - követve az 1560-as óvári ${ }^{227}$ és az 1566-os váradi $^{228}$ kiadások címadásait - Vasárnapi prédikáció után való hálaadás címmel szerepel a prédikáció utáni énekek között, de az 1579-es debreceni kiadás már lényegesen rövidít a címen: a szentegyházban való énekek között Hálaadás címmel szerepelteti. Az 1590-es debreceni kiadás az 1569-es címből a funkció (a hálaadás a címekben a vizsgált anyag alapján inkább funkciót jelöl, mint kialakult müfajt) helyett inkább az ének istentiszteletbeli helyét hozza, s itt az Invocationes Spiritus Sancti fejléc alatt Predikatio elött címmel szerepel. Ez az ének arra is jó példa, hogy a debreceni ágon megfigyelhető, kiadásonkénti címegyszerüsítést Újfalvi Imre 1602-es debreceni énekeskönyve ismét átdolgozza, s olykor teljesen más funkcióra, müfajra vagy alkalomra utaló kifejezéssel látja el az énekeket az addigi címekhez képest. Itt ez az ének a „külömb-külömbféle énekek” között Imádság, azaz hálaadás és könyörgés címmel található. Ez a három ma müfaji jellegünek számító terminus itt valószínüleg inkább a szöveg funkciót jellemzi, hiszen az ének először hálaadásra szólít fel, majd kegyelemért és egyebekért könyörög az Úristenhez. Újfalvi Imre címadása rávilágít arra, hogy a legtöbb, az Úristenhez forduló ének - noha müfajilag imádságként lehetne meghatározni,-- mindig tartalmaz hálaadó és kérő vagy könyörgő funkciót is. Ez alapján úgy tünik, a szerkesztők érzik az apró különbséget a kifejezések között, ám szoros értelemben vett műfaji elkülönülésről még nem beszélhetünk. E három terminus egy énekre való alkalmazása párhuzamba hozható a Csomasz Tóth Kálmánnak ${ }^{229}$ azzal a megfigyelésével, hogy az énekeskönyv-előszavakban, illetve az énekléssel kapcsolatos írásokban gyakran idézett Szent Pál-hely ${ }^{230}$ inkább szinonimákat, mint különböző műfaji meghatározásokat tartalmaz. Csomasz Tóth itt a psalmusokra, dicséretmondásokra és lelki énekekre utal. ${ }^{231}$ Talán az Újfalvi-féle példa annyival árnyalhatja ezt a megfigyelést, hogy ezek a kifejezések - bár nem

\footnotetext{
${ }^{227}$ A cím: Más hálaadás a vasárnapi prédikáció után, s a Prédikáció után való könyörgések között található.

${ }^{228}$ A cím: Más hálaadás a vasárnapi prédikáció után, s a Prédikáció után való könyörgések között található.

${ }^{229}$ CsOMASZ Tóth KÁlmán: A református gyülekezeti éneklés, 1950, 29.

${ }^{230}$ Pál levele a kolosséiakhoz, 3,16.

${ }^{231}$ Idézi még: HuBERT 1989, 299.
} 
konkrét műfajokat takarnak - tartalmaznak egymástól eltérő funkciókat, árnyalatnyi különbségeket. Újfalvi példája tulajdonképpen azt mondja, hogy az adott imádság hálaadásból és könyörgésből áll. Ezt az éneket az 1602-es énekeskönyv a „külömb-külömbféle” énekek közé sorolja egyébként, ami Hubert Gabriella ${ }^{232}$ szerint a nem ünnepi énekeket jelenti Újfalvinál.

Az Újfalvi-féle kiadás által adott cím jól mutatja azt a korai újkorban folyamatosan alakuló műfaji rendszert, amelyről teljes képet csak minden egyes szövegváltozat - hiszen, mint látjuk, az egyes kiadások címadási szokása eltérő - regisztrálása után kaphatunk. Mai müfajfogalmunk szerint a könyörgés és a hálaadás önmagában is müfaji értékkel bírhat, s valóban találunk számos példát arra, hogy egy-egy éneket könyörgés, vagy hálaadás címmel látnak el a szerkesztők. Újfalvi címadása viszont rávilágít arra, hogy az imádság mint müfaj kétféle müfaji funkciót egyesít, a könyörgést és a hálaadást. Mai fogalmunk szerint az imádságon mint müfajon alapvetően prózai szövegeket értünk, ez a szöveg viszont a gyülekezeti énekek része, s mint ilyen, feltehetően énekelve hangzott el. Az énekeltségére utal az 1632-es és az 1697-es kolozsvári gyülekezeti énekeskönyvben szereplő címe is: az Adjunk hálát mindnyájan... itt Ante Concionem Canend. címmel szerepel, tehát a prédikáció előtti énekként van meghatározva. Az énekelt imádság a vizsgált korszakban természetesnek mondható, hiszen az énekeskönyvek előszavaiban, az éneklésről írott korabeli elmélkedésekben, prédikációkban gyakran leírják, hogy az ének akkor számít imádságnak, ha az könyörgés vagy hálaadás. Ilyen például a H. Hubert Gabriella által idézett Martonfalvi Tóth György-szöveg. ${ }^{233}$ Ebben Martonfalvi kifejti, hogy a hangosan mondott imádságnak két fajtája van, a prózai, például a Miatyánk, ${ }^{234}$ illetve a verses és ritmikus imádságok, melyek lehetnek könyörgések és hálaadások. ${ }^{235}$ Úgy tűnik tehát, hogy müfajilag ezek a korban nem az imádságon belül elkülönített alműfajok, hanem az imádságnak az Istenhez való odafordulás szándékát, okát, funkcióját mutatják meg: kérünk valamit az énekkel, vagy éppen hálát adunk valamiért. Újfalvi címadása azt mutatja meg, hogy ebben az énekben az imádságnak mind a két funkciója érvényesül. Így Pirnát Antal nyomán mondhatjuk, hogy a 16. századi (17. század eleji) címadási szokásokban gyakori a pontos műfaji megjelölést adó címtípus, ${ }^{236}$ ám e

\footnotetext{
232 HUBERT, 1989, 300.

${ }^{233}$ Martonfalvi Tóth György, Exegesis... (Ames-kommentár), 1675. RMK II. 1161. Idézi H. HuBERT, A régi magyar gyülekezeti ének... 29. és 57.

${ }^{234}$ Meg kell jegyezni, hogy az 1632-es kolozsvári unitárius énekeskönyv a Miatyánkhoz is tesz nótajelzést, így úgy tünik, azokat a Miatyánk-parafrázisokat, melyek ritmikusak voltak, szintén énekelhették.

${ }^{235}$ H. HUBERT i.m. 57.

${ }^{236}$ PIRNÁt Antal, Balassi Bálint poétikája,(Humanizmus és reformáció 24.) Bp., Balassi, 1996, 46.
} 
pontos műfaji megjelölés nem tévesztendő össze a mai műfajfogalommal, inkább műfaji összetevőként értelmezhető.

Az Adjunk hálát mindnyájan... kezdetü ének az 1602-14 közötti bártfai evangélikus kiadásban már egyszerübb formában szerepel: a hálaadó dicséretek között található meg, s egyszerüen csak a Más elválasztó funkcióval van jelölve. Az 1602-15 közötti kolozsvári unitárius kiadás a „külömb-külömb” énekek között hozza Prédikáció előtt címmel.

Talán ebböl az egy példából is látható, hogy a zsoltárokon kívül a többi gyülekezeti ének esetében is megfigyelhető a címek egyszerüsödése, s ahogyan az énekeskönyvek szerkezeti egységei egyszerűsödnek, a címek is egyre kevesebb információt tartalmaznak. Újfalvi címadása kivételnek mondható, hiszen ő mind a címek, mind a nótajelzések tekintetében - ahogyan azt a következő fejezetben látni fogjuk - újításokat fog bevezetni. Így az általa megadott apparátuskészlet nem a protestáns gyülekezeti énekeskönyvek hagyományának tendenciáit érvényesíti, hanem újító szándékúnak tünik.

A címek egyszerüsödése, rövidülése nyilván összefügg azzal is, hogy már nem a kántornak, hanem a gyülekezetnek a kezébe szánják, így nem kell feltétlen minden alkalmat, funkciót, utasítást tartalmaznia a címnek, sőt feltételezhetjük, hogy a gyülekezet inkább ismeri incipitről az egyes énekeket, mint címről vagy zsoltárszámról. A kéziratos forrásokban a címadással egyébként még kevésbé foglalkoznak a szöveg lejegyzői, az Adjunk hálát mindnyájan... szövegét a Bölöni-kódex például a „Szép ének ez.” mondattal látja el cím helyett, a Csonka antifonálé pedig cím nélkül hozza.

A 17. századi unitárius hagyományban a nem zsoltár műfajú verses címei már igen egyhangúnak mondhatók. Az 1602-15 közötti kolozsvári unitárius énekeskönyv zsoltárrésze a zsoltárokat minden esetben „Psalmus + római szám” típusú címmel illeti, némely esetben használja az „Idem Psalmus” címet, ha az előtte álló zsoltárnak következik egy másik parafrázisa. A zsoltárok között egyébként 65 ének található.

Az egyéb énekeknél 53 verses szöveg található. Itt 2 zsoltár ugyanígy, tehát „Psalmus+római számmal” van ellátva, 5 esetben pedig nincs megadva az, hogy zsoltárról van szó, csupán a hivatkozó strófában. A többi ének pedig olyan típusú címet visel, amelyek inkább elválasztó funkciót tükröz, mintsem címként funkcionálna, például: Más ének (11 esetben), Más szép ének (szintén 11 esetben). Ezen kívül a már említett müfaji jellegü, vagy alkalom, használat illetve funkció szerinti elnevezéseket használ, mint például a Szép dicséret, a Prédikáció elött, vagy Szép vigasztaló ének.

Az 1632-es kolozsvári unitárius énekeskönyv ehhez képest már lényegesen egyszerüsít, ugyanis a zsoltárok már arab számmal, az egyéb énekek pedig a legtöbb esetben 
csupán Alia vagy Más jelzéssel találhatók meg. Úgy tünik, az incipitek szerinti ábécérend miatt az unitárius hagyományból kezdenek kikopni az alkalmat, funkciót jelölő cím-típusok, sőt, mint az előző fejezetben láttuk, olykor a zsoltárszámok is eltűnnek. ${ }^{237} \mathrm{Az}$ 1697-es kolozsvári gyülekezeti énekeskönyv címadási szokásaira az Alia és a Más tagoló egység, elválasztó funkció használata még inkább jellemző lesz.

Az új helyzetben tehát nem szükséges információkká válnak a 16. században még a kántorok számára fontos információhordozók: az apparátuskészlet, ${ }^{238}$ a funkciót, alkalmat, műfajt vagy témát jelölő cím, a zsoltár száma (esetleg latin kezdősora), a gyülekezeti énekeskönyv szerkezeti egységén belül elfoglalt helye (hiszen a fejlécekben általában ez utóbbi is látszik).

A gyülekezeti énekeskönyvek ugyanis már nem csak a kántor és a kórus kezében vannak, hanem a gyülekezetében is. Így elegendő az az információ, amely addig is a gyülekezetnek szólt, a gyülekezet számára volt benne, vagyis maga a szöveg, esetleg a nótajelzés. ${ }^{239} \mathrm{Az}$ unitárius énekeskönyvekben ez a gyakorlat az ábécérend bevezetése, illetve az ábécérend következményeképp szükségtelenné vált címek, zsoltárszámok elhagyása folyományaként az egyéb énekek terén már az 1602-15 közötti kolozsvári kiadásban is, a zsoltárok terén pedig az 1632-es kiadástól kezdődően markánsan megmutatkozik.

Látható, hogy ez a többi protestáns felekezettől eltérő, de a gyülekezeti éneklés számára igen praktikusnak mondható út. Ám ugyanígy, - ahogyan arra rámutattunk, - a kéziratos gyüjtemények és a nyomtatványok - felekezettől függetlenül is - egyszerüsítik a címeket.

Mivel a rendelkezésre álló fennmaradt adatok azt mutatják, hogy magánhasználatra szánt énekeskönyveket legelőször az unitáriusok adtak ki, így érdemes a címadás tekintetében ezeket is megvizsgálni, hiszen ezek a kiadások eleve nem templomi, hanem otthoni használatra, éneklésre születtek. Ahogyan azt már említettük, jelenleg csak az 1700-as kiadást tudjuk kézbe venni (RMK I. 1558-59), ám ennek az első része azonos az 1623-as elveszett kiadással. Az 1700-as énekeskönyv a zsoltárokat „Psalmus+római szám” címmel illeti, s az egyéb énekek közül a leggyakoribb a Más elválasztó funkció használata, sőt, igen gyakran cím nélkül, csupán nótajelzéssel kezdődnek az énekek. ${ }^{240}$ A nótajelzések változásáról

\footnotetext{
${ }^{237}$ Lásd a Keresztyéneknek Istene... (RPHA 732) és az Úrnak szolgái, no dicsérjétek... (RPHA 1447) kezdetű énekeket.

${ }^{238}$ LATZKOVITS, i.m., 152.

${ }^{239}$ Mivel az éneklés a kórus segítségével ment, így a legegyszerübb módja a gyülekezet számára egy ének megtalálásának, ha incipit alapján keresheti.

${ }^{240}$ Természetesen vannak kivételek, de ezek száma igen kevés, ilyen, egyéb címet találunk például az 1700-as kiadás saját bővítményénél, Rimay Legyen jó idő csak... kezdetű versénél is, melynek címe Metaphorica cantio.
} 
érintőlegesen a dolgozat későbbi fejezete szól majd, de már itt érdemes megjegyezni, hogy a gyülekezet által használt, a használatot megkönnyítő funkcióként a nótajelzések korpuszon belüli átalakulása is megfigyelhető. Az első unitárius gyülekezeti énekeskönyv (1602-15, Kolozsvár) ugyanis alig használ nótajelzést.

Az 1700-as magánhasználatra szánt kolozsvári unitárius énekeskönyv első része, a Szép isteni dicséretek és hálaadások címmel ellátott rész összesen 30 éneket tartalmaz, és ez a 30 ének azonos az 1623-as elveszett magánhasználatra szánt énekeskönyv incipitjegyzékével. ${ }^{241}$ Feltételezhető, hogy ezek az énekek szövegváltozatukban, címükben sem térhetnek el nagyon a korábbi két $(1623,1635)$ kiadástól, ugyanis az 1700-as kiadás cím nélkül újrakezdi az ábécérendet a 30 ének után, s még 36 éneket told az előző kiadásokéhoz. Nem veszi bele tehát az előzőek közé, hanem újrakezdi az ábécérendet. Azt, hogy az 1700-as kiadás korábban is megjelent része valószínüleg nem tartalmaz lényegi eltéréseket az elveszett kiadásokhoz képest, abból is feltételezhetjük, hogy az 1635-ös unitárius kiadás ${ }^{242}$ makulatúrájából kiolvasható énekek pontosan egyeznek az 1700-as kiadás szövegváltozataival, címeivel. Éppen ezért valószínű, hogy a többi éneken sem változtattak nagyon. Így az 1700-as kiadás első énekrendje talán arra is választ ad, hogy milyen címadás volt a magánhasználati énekeskönyvek kezdeti kiadásaiban. A 30 ének összesen 15 féle címet tartalmaz. A címekből egy-egy valamilyen témát, tartalmat közvetít, például Bosszúság szenvedésröl vagy Ez világ rövid voltáról. Azt is megfigyelhetjük, hogy a magánhasználatra szánt énekeskönyv címei nem tagolhatók be a protestáns gyülekezeti énekeskönyvek címhasználatába, ugyanis még a címben müfaji jellegü megnevezést vagy tartalmi utalást tartalmazó esetekben is ezek inkább élethelyzetekre, az emberi élet szakaszaira, mindennapjaira utalnak. Úgy tünik, ezek a címek inkább azt fejezik ki, hogy mikor, kinek érdemes az adott éneket elővenni, énekelni. A 15-ből 13 nem ismétlődő cím csaknem mindegyike egy-egy élethelyzetre utal, vagy arra applikálható. (Például: Békességkérö ének, Ifjak éneke, Vigasztaló ének, Úton járó ember éneke, Isteni szolgálatra intő dicséret, Hálaadó dicséret, Étel után való dicséret stb.) Ezek a címek úgy tartalmazzák tehát a műfaji jelleget vagy a témát, az elhangzás idejét, hogy azt az emberi élet egy-egy helyzetére lehessen alkalmazni. A szerkesztők tehát figyelembe veszik a kiadás célját, s ugyanannak az éneknek, amely a gyülekezeti énekeskönyvben is szerepel, gyakran más, a mindennapi életben alkalmazható címet adnak a magánhasználati gyüjteményekben. Az is feltűnő, hogy a 30 ének közül 9 van ellátva Psalmus címmel, - ebből csak egynek van nótajelzése - de 8 cím nélküli

\footnotetext{
${ }^{241}$ VÁRFALVI, i.m.

${ }^{242}$ RMNy 1615.
} 
ének is található közöttük. A cím nélküli énekeknek minden esetben van nótajelzésük is. Ezeknek - a zsoltároknak és a cím nélküli énekeknek - mindegyike megvolt már az 1602-15 közötti kolozsvári gyülekezeti énekeskönyvben is, tehát feltételezhetjük, hogy ezek használatát ismerték az énekeskönyv tulajdonosai. Az is érdekes, hogy az egyéb élethelyzetre alkalmazható szövegek közül (13 szöveg) csak kettőnek van nótajelzése. A 30 ének 11 nótajelzéséből tehát csak 3 esetben van olyan helyen nóta, ahol cím is található, a fennmaradók mindegyike a cím nélküli énekek esetében regisztrálható.

Ezek az adatok az 1700-as kiadás bővítményében található énekek vizsgálatával kiegészülnek, s a változási tendencia láthatóvá válik. Ahogyan az énekek egyre inkább ismertek lesznek, egyre inkább rögzülnek a templomi használatban, úgy tünnek el az otthoni, magánhasználatra szánt énekeskönyvböl a zömmel az élethelyzetre utaló címek. Az 1700-as kiadás 36 bővítménye összesen egy Vigasztaló éneket, 4 Más felirattal kezdődő éneket, 9 Psalmus címmel ellátott éneket és 22 cím nélkülit tartalmaz. A 36 énekből 29-nek van viszont nótajelzése. Ez alapján úgy tünik, hogy a gyülekezetben megszokott, bejáratott énekek esetében a 17. század első harmadában az unitáriusok még alkalmazták a magánájatosságra szánt énekeskönyvekben az ilyen, használatra vonatkozó címeket, de 1700-ban a bővítmények már nemigen tartalmaznak ilyesmit, helyette a nótajelzés lesz fontos.

\section{I. 1. Összegzés}

Összefoglalva a protestáns hagyományban bekövetkező címadási szokások változásait azt mondhatjuk, hogy ahogyan a gyülekezeti énekeskönyvek egyre inkább elérhetőek lesznek a gyülekezet számára is, úgy válnak az énekeskönyvek szerkezetei egyre egyszerübbé, s az énekek apparátuskészlete úgy rövidül, egyszerűsödik az esetek többségében egy rövid címre és egy nótajelzésre. 


\section{I. 2. Nótajelzést érintő változások}

A protestáns hagyományban a legkorábbi kiadások (1536, Krakkó ${ }^{243}$ és 1560 Óvár) készítői kottával ellátott gyülekezeti énekeket igyekeztek megjelentetni. Az 1536-os krakkói kiadás töredékeiben tíz ének maradt fenn, mind a tíz kottával együtt. ${ }^{244}$ Az 1560-as óvári kiadásban Huszár Gál 105 gyülekezeti éneket közöl, s ezek közül 11 ének esetében nincs kotta vagy nótajelzés a kiadásban. ${ }^{245}$ Ezt követően egyre kevésbé jellemző, hogy kottás kiadások jelenjenek meg, mi több, a nótajelzések is gyakran tűnnek el. Feltűnő az is, hogy a kéziratos énekgyüjtemények esetében csak igen ritkán használnak nótajelzést. Ennek okát érdemes a kéziratos források használatában, az elkészítés módjában és funkciójában keresni.

A legtöbb kéziratos forrásunk feltehetően olyanok számára készült, akik ismerték az adott énekeket, így nem volt szükséges a nótajelzést megadni. Ez érvényes akkor is, ha a másoló vagy lejegyző magának készítette a gyüjteményt, de akkor is feltételezhetjük, hogy a használó ismerte az énekek dallamát, nótáját, ha az adott gyüjtemény például egy kisebb gyülekezet kántora számára készült, mint azt például a Bölöni-kódexről gondoljuk. A kéziratos énekgyüjtemények kapcsán Csörsz Rumen István megállapítja, hogy a 18. században is a nótajelzés nélküliség a jellemző, bár a kollégiumi környezetben született versgyüjtemények esetében gyakoribbak a 18. században a nótajelzéssel, kottával ellátott verses szövegek, mint az elszigetelt helyeken születő versgyüjteményekben. ${ }^{246}$ A gyülekezeti énekek 16. század végi, 17. század eleji variabilitását a kéziratos források egyébként is sokkal erőteljesebben prezentálják, mint a nyomtatványok, hiszen a nyomtatványokban mindig a kiadó városában, a szerkesztőnek vagy az összeállítónak a gyülekezetében ismert, aktuális szövegváltozat jelenik meg, amelybe a szerkesztő időnként belenyúl, apró változtatásokat végez. A kéziratos források viszont éppen azt mutatják meg, hogy egy-egy „vidéki”, nyomdával nem rendelkező város gyülekezete mit, hogyan énekelt az ott birtokukban lévő esetleges nyomtatott, kéziratos források alapján. A későbbiekben majd látjuk néhány szöveg példáján keresztül, hogy a Bölöni-kódex egy-egy éneke annak ellenére, hogy alapvetően unitárius gyülekezeti énekeket tartalmaz, s ez a dogmatikai szempontokban szinte minden esetben érvényre jut, néhol a nyomtatott unitárius gyülekezeti énekeskönyvek

\footnotetext{
${ }^{243}$ RMNy 18.

${ }^{244}$ H. HUBERT, i.m., 107.

${ }^{245}$ H. HUBERT, i.m., 111.

${ }^{246}$ CSÖRSZ Rumen István, Szöveg szöveg hátán (A magyar közköltészet variációs rendszere 1700-1840), Irodalomtörténeti Füzetek, Bp., Argumentum, 2009, 91.
} 
szövegváltozatától igen távol áll, és az a távolság időnként a debreceni vonalhoz, máskor a bártfai evangélikus kiadásokhoz közelíti a kéziratban található gyülekezeti énekek szövegváltozatait. Nem valószínü, hogy az énekek összeírója (szándékosan nem használva a másoló kifejezést) öt-hat, vagy akár nyolc-tíz nyomtatványt és kéziratos forrást a kezében tartva kontaminál, szerkeszti össze például a Bölöni-kódex egy-egy énekét Háromszéken. Sokkal valószínűbb, hogy a gyülekezet által énekelt verses szövegeket rögzíti, s adott esetben igyekszik javítani a megfelelő dogmatikai álláspontot képviselő változatra.

A kéziratos források nótajelzés- és kottahasználata a 16. századi, 17. század eleji, gyülekezeti énekeket tartalmazó gyüjtemények esetében tehát elenyésző, - kivételt képeznek ez alól természetesen a megrendelésre, egy-egy gyülekezet számára készített nagyalakú, éppen a kottákat is rendezni, rendszerezni kívánó graduálok, - ám a nyomtatott hagyományban a nótajelzések továbbra is megmaradnak. ${ }^{247}$

A debreceni kiadások (az 1569-es, 1570-es, 1579-es és az 1590-es) a zsoltárok esetében gyakran el is hagyják a nótajelzést. Ezek föleg olyan esetekben fordulnak elö, ahol a korábbi, 1560-as óvári kiadásnál kottát is közöltek, valószínü tehát, hogy egyrészt a kántor ismerte akár a kottát is, másrészt a gyülekezet is hozzászokott, megtanulta, megismerte egyegy zsoltár dallamát addigra. Ilyen zsoltár például a Keresztyéneknek Istene... (RPHA 732) vagy a Hogy panaszolkodik a hatalmas Isten... (RPHA 550) incipitü. Az 1560-as óvári kiadásban mindkettőnek van kottája, ám a debreceni vonalon nótajelzés és kotta nélkül vannak jelen. A dallamok ismeretével feltehetően az 1574-es komjáti és az 1582-es detrekői kiadás is számol, itt ugyanis jellemzően vagy a zsoltár latin incipitjét közlik a psalmus címe után, - ilyennel találkozunk a Keresztyéneknek Istene... esetében - vagy megjelenik a latin incipit mellett a magyar nótajelzés is, melyre példa a Hogy panaszolkodik... kezdetü ének, ahol az 1574-es és az 1582-es kiadás címe és nótája is megegyezik: L. Psalmus. Deus Deorum Dominus locutus est. Nótája: A hatalmas Isten, királyoknak királya...

Az 1574-es komjáti és az 1582-es detrekői kiadás esetében a címekhez hasonlóan a nótajelzések is a legtöbb esetben megegyeznek, ám a szövegváltozatok nem minden esetben azonosak.

A nótajelzések vizsgálata, ahogyan arra többen kitérnek, ${ }^{248}$ gyakran háttérbe szorul a szöveghagyományokat feltáró monográfiákban, tanulmánykötetekben, pedig az énekek, az egyes énekeskönyvek közötti hálózatok feltérképezésében, sőt, a korabeli verses szövegek

${ }^{247}$ A dolgozat a kottákkal nem foglalkozik részletesen, mivel az külön zenetörténeti ismereteket igényelne. Mindenesetre azt érdemes lehet továbbgondolni, hogy mely nyomdahelyen volt adott az infrastruktúra a kottás kiadásokhoz, s ha esetleg adott volt, akkor ott milyen gyakran adtak ki kottás nyomtatványokat.

${ }^{248}$ pl. CSÖRSZ, i.m., 88. 
ismertségére vonatkozóan is hasznos információkkal szolgálhatnának. A vizsgált anyagból csak néhány ilyen, mellékesnek tekinthető, ám a gyülekezeti énekhasználatnak a nyomtatott hagyományozódáson túlmenő adata is felszínre kerülhet. Vannak olyan verses szövegek, melyek a kéziratos és a nyomtatott protestáns hagyományban alig maradtak fönn, ilyen például a csak unitárius hagyományon belül található Az Úristent az egész föld... incipitü ének. Ezt az éneket az RPHA nem közli, mivel az első fennmaradt változata az 1602-15 közötti kolozsvári unitárius énekeskönyvben található. Érdekes viszont, hogy Újfalvi Imre 1602-es debreceni református énekeskönyve az Aki veti segedelmét... kezdetű (RPHA 74) zsoltár nótájaként $A z$ Úristent... incipitet ad meg. Az RPHA alapján nincs másik olyan verses, Az Úristent... kezdetű szöveg, amelynek a metruma rokonítható lenne az Aki veti segedelmét... kezdetü énekével. Bár itt most nem dallamról beszélünk, - a későbbiekben még lesz szó arról, hogy miért nem csak a dallamot nézzük, - az Aki veti segedelmét... a16 a16-os metrumához szótagszám tekintetében illik az Az Úristent az egész föld... kezdetű ének a8 a8 b8 b8-as metruma. Söt, ennek a csak unitárius környezetben hagyományozódó szövegnek a nótajelzése az 1697-es kolozsvári unitárius énekeskönyvben az Aki veti segedelmét... lesz, így minden valószínüséggel az 1602-es debreceni kiadás igen rövid nótajelzése is ezt a verses szöveget takarja. Mivel nótajelzésnek általában olyan énekeket adnak, melyeket mindenki ismer, így feltételezhetjük, hogy az Az Úristent az egész föld... 1602-es nótajelzésként való használatakor a reformátusok ismerték az éneket, bár nyomtatott forrásban csak az unitárius gyülekezeti énekeskönyvek őrizék ezt meg. Attól tehát, hogy ez az ének csak unitárius forrásokból maradt ránk, nincs kizárva a más felekezetekben való ismerete, használata sem.

Hasonló, de inkább az énekek ismertté válásának gyorsaságát szemléltető példa a Mindenek meghallják és jól megtanulják... (RPHA 968) kezdetű zsoltár nótajelzése az 1560as óvári kiadásban. Ebben a nótajelzés Bornemisza Péter Siralmas énnékem... kezdetű éneke, amelynek keletkezési idejét az 1550-es évek közepére szokás tenni, bár Nemeskürty István egészen pontosan 1557 januárjára datálja. ${ }^{249}$ Akárhogy is van, tudtunkkal a szöveg nyomtatásban ebben az időszakban nem jelent meg. Így azt kell feltételeznünk, hogy kb. 5 év alatt kéziratos és/vagy szóbeli hagyományozódás révén olyan ismertté vált, hogy annak ellenére, hogy az ének nem egyházi szöveg, nótajelzésként szerepelhet egy gyülekezeti énekeskönyvben. ${ }^{250}$

Az, hogy nótajelzésként nem gyülekezeti ének van megadva, hanem a korban ismert vallásos vagy világi egyéb szöveg, nem ritka. Feltűnő a históriás (bibliai vagy antik történetet

\footnotetext{
${ }^{249}$ NeMESKÜRTY István, Bornemisza Péter: Cantio optima = A régi magyar vers , Bp., Akadémiai, $1979,95$.

${ }^{250}$ Az RMDT alapján dallama a 16. századból nem maradt fenn.
} 
elbeszélő) énekek nótajelzésként való használata. Tendencia-szerủen érvényesnek mondható, hogy a históriás énekek hivatkozásként való használatát Újfalvi 1602-es debreceni énekeskönyve és az 1602-15 közötti kolozsvári unitárius énekeskönyv igyekszik kivenni a nótajelzések közül, és mást illeszteni oda. Ami, ha a metrumot nézzük, nem is nehéz dolog, hiszen a többségük olyan metrummal rendelkezik, amely igen gyakori a 16. században. Az énekeket história nótajelzéssel ellátó kiadás jellemzően az 1574-es komjáti, s ezt követi az 1582-es detrekői is. A bártfai kiadások (1593 és 1602-14) néhol meghagyják a históriát nótajelzésként, néhol viszont kiveszik, tehát nem járnak el olyan következetesen, mint az Újfalvi-féle. Az alábbi két példa szemlélteti az elmondottakat, de ezen kívül jól mutatja mind a címek egyszerüsödését, mind a kéziratok cím- és nótajelzés-adási szokásait, melyeket az előzőekben már említettünk:

\section{RPHA 1042 Nagy Úristen, ne hagyj minket - Háborúságnak idején könyörgés}

Szerzője ismeretlen, nem dedikált. Idegen minta: nincs azonosítva. Nincs akrosztichonja. Nincs kolofon. Keletkezési idő nem később, mint 1569. Metrum: a8(4,4), a8(4,4), a8 $(4,4)$, a $8(4,4)$

Kéziratos forrásai: ${ }^{251}$

Bölöni-kódex, 1615-1621, (S 30) p. 30, cím: Praecatio ad Deum. Nóta: nincs.

Csonka antifonálé, 1607-1632, unitárius (S 143) p. 92r, cím és nóta nélkül.

\section{Nyomtatott kiadásai:}

Debrecen, 1569, (RMNy 264, [fakszimile kiadás]) p. 208, Közönséges dicséreteknél, cím: Szép dicséret a Magasztallak én Istenem nótájára... ${ }^{252}$

Komjáti, 1574, (RMNy 353/2, [fakszimile kiadás]) p. C. A szentegyházban való isteni dicséreteknél, cím: Más dicséret azon nótára, az előző nótája: Dicséretes példát mondok nektek... ${ }^{253}$

Detrekő, 1582, (RMNy 513, [fakszimile kiadás]) p. 138 ${ }^{\mathrm{r}}$, közönséges isteni dicséretek, Más dicséret azon nótára, előző nóta: Dicséretes példát mondok nektek... ${ }^{254}$

Debrecen, 1590, (RMNy 640) p. 247, Az Úr vacsorájáról részben, cím: Alia. A Magasztallak én Istenem nótájára. ${ }^{255}$

\footnotetext{
${ }^{251}$ Bár minden esetben az RPHA adatait vettem alapul, s azokat egészítem ki, a források közül csak azt tüntetem fel, amelyiket volt alkalmam kézbe venni, és összevetni a többi változattal.

${ }^{252}$ RPHA 850, a metruma azonos: a8 $(4,4)$ a8 $(4,4$,$) a8 (4,4)$ a8 $(4,4)$.

${ }^{253}$ A Dicséretes példát mondok nektek, asszonyi állatok... csak nótajelzésként ismert, de feltételezzük, hogy éppen ezért ismert volt a korban, bár sem kéziratos, sem nyomtatott formában nem maradt ránk.

${ }^{254}$ Látható, hogy az 1582-es kiadás az 1574-est veszi át, nem a debreceni nótajelzést.

${ }^{255}$ A debreceni vonalon a nótajelzés is megmaradt az 1569-es debreceni kiadásé.
} 
Bártfa, 1593, (RMNy 713) p. 246, A szentháromság nap után való dicséretek részben, cím: Alia. A Magasztallak én Istenem nótájára. ${ }^{256}$

Debrecen, 1602, (RMNy 886/1) p. 124v a „külömb-külömbféle” énekeknél, cím: Más. Nóta nincs.

Bártfa, 1602-1614, (RMNy 965) p. 353, külső háborúságba való dicséretek részben, cím: Más, a Magasztallak én Istenem nótájára.

Kolozsvár, 1602-1615, (RMNy 983) p. 522, a második énekrészben, cím: Más szép ének.

Kolozsvár, 1632, (RMNy 1541) p. 512, zsoltár és egyéb énekrészben, cím: Más. Nóta: Reménységem nincs már... ${ }^{257}$

Kolozsvár, 1697, (RMK I 1503) p. 348, zsoltár és egyéb énekrészben, cím: Más. Nóta: Reménységem nincs már...

\section{RPHA 1425 Uram, benned még az én reménységem - Keresztyén rabok könyörgése}

Szerezte Palatics György, nem dedikált. Akrosztichonja: V PALATICH GyÖRGI SzSzERSzEMTTEM. A kolofon tájékoztat a szereztetés körülményeiröl; hely: Csonkatoronnak erős tömlöcében; idő: Ezerötszáz és hetven esztendőben; szerző: Palaski György; szerző: Az, ki szerzé, igen bízik Istenben, Hogy nem hagyá soká az büntetésben. Keletkezési idő 1570.

Modern kiadása: RMKT-8-169.

Metrum: a11(6,5), a11(6,5), a11(6,5), a11(6,5)

\section{Kéziratos forrása:}

Detsi-kódex, 1609-1613, világi (S 25) p. 35 , cím: Alia optima. Nóta nincs. A végén van évszám: 1609.

\section{Nyomtatott források:}

Komjáti, 1574, (RMNy 353/2, [fakszimile kiadás]) p. $118^{\mathrm{r}}$, a fejléc: a szentegyházban való isteni dicséretek. Cím: Palatics György éneke, mely a keresztyén rabok könyörgésének formája, Nótája egyik, az Abigél énekének melódiája. ${ }^{258}$

${ }^{256}$ Ebben az esetben a bártfai evangélikus kiadások nótajelzése a debreceni kiadásokét veszi át.

${ }^{257}$ Az 1632-es unitárius kiadás nótajelzése, amennyiben ez Balassi szövegére utal, semmiképpen nem jön ki a metrumra. Így itt vagy egy ma nem ismert dallamra kell gondolnunk, és valóban Balassi dallamára énekelték, vagy arra - ahogy azt a későbbiekben majd kifejtjük - hogy az 1632-es kiadás a nótajelzések megadásánál inkább a metrum azonosságára fektet hangsúlyt, s így feltehetően tévedés okán került be Balassi szerelmes éneke (nem vallásos szövegként egyedül) a nótajelzések közé. Ebben az esetben az unitáriusoknál két lehetőség is fennáll: vagy Rimay Reménységem te légy nékem-jére gondoltak, vagy a csak unitárius forrásból ismert, Papp Géza által lengyel mintájú éneknek mondott Reménységem vagy Istenem... kezdetủ énekre. Ennek az éneknek egyébként már a legkorábbi nyomtatott forrása is (1602-15 Kolozsvár) - a Nota Polonica jelzés mellett Balassi $O$ én kegyelmes Istenem... kezdetủ énekét hozza nótajelzésként, melyet, ha a Balassi-szöveghagyományt nézzük, a jelenlegi ismereteink szerint elvileg nem is ismerhettek. Ennek ellenére legkésőbb 1616-ban nótajelzésként hivatkozzák, tehát mint a többség számára ismert szöveget és dallamot említik. A korai Balassihagyományról a dolgozat későbbi fejezeteiben lesz szó részletesen.

${ }^{258}$ Az Abigél históriájának legkorábbi kiadása jelenlegi ismereteink szerint 1571-es, (RMNy 299) tehát három évvel korábban jelent meg nyomtatásban, s máris nótajelzésként hivatkozzák. Mivel a história kolofonja 1560-ra keltezi a megírás dátumát, feltételezhetjük, hogy a nyomtatás elött ez a história is nagy népszerúségnek örvendett. 
Debrecen, 1579, (RMNy 429) p. 182, a szentegyházba való énekeknél, cím: Palatics György éneke.

Detrekő, 1582, (RMNy 513, [fakszimile kiadás]) p. 153 ${ }^{\mathrm{r}}$, cím: Palatics György éneke, mely a keresztyén rabok könyörgésének formája, Nótája egyik, az Abigél énekének melódiája

Bártfa, 1593, (RMNy 713) p. 310, a szentháromság nap után való dicséretek fejlécnél, cím: Palatics György éneke. Az Abigél énekének melódiája. ${ }^{259}$

Bártfa, 1602-1614, (RMNy 965) p. 263, a hitbéli bizodalomról fejlécnél, cím: Palatics György éneke. Az Abigél énekének melódiája.

Kolozsvár, 1602-1615, (RMNy 983) p. 549, „külömb-külömb ájtatos dicséretek” között, cím: Rabok éneke.

Kolozsvár, 1632, (RMNy 1541) p. 598, zsolt. és egyéb énekrészben, cím: Alia. Nóta: Nagy bánatban Dávid mikoron... ${ }^{260}$

Kolozsvár, 1697, unitárius (RMK I 1503) p. 423. zsolt. és egyéb énekrészben, cím: Alia. Nóta: Nagy bánatban Dávid mikoron...

E példában nem tekinthetünk el attól, hogy nótaként több helyen is az (egyik,) Abigél énekének melódiája szerepel. Ezek alapján, főleg a későbbi kiadások nótajelzés-használatát látva, talán azt feltételezhetjük, hogy itt egyértelmüen jelezve van, hogy a nóta dallamot melódiát - jelöl, nem pedig azt, hogy a szótagszámnak megfelelően milyen énekre lehet ráénekelni az adott gyülekezeti éneket vagy zsoltárt. Az RPHA szerint az Uram, benned még az én reménységem... metruma a következő: a11 (6,5) a11 (6,5) a11 $(6,5)$ a11 $(6,5)$. Ezzel szemben az, bár 4Xa11 a képlete, de 4/7-es osztatú. A dallamban ez feltehetően nem okozott problémát.

Megfigyelhető viszont, hogy Újfalvi 1602-es debreceni kiadása a legtöbb ének mellé az előző kiadásokhoz képest gyakran új nótajelzést tesz. A kottával és/vagy latin incipittel hivatkozott zsoltárok mellé sok esetben helyez olyan, az eddigiekhez képest új nótajelzést, amely már - annak ellenére, ha a dallamát nem is ismerjük - pontosan olyan szótagszámú és osztatú énekre mutat, mint a nótajelzésként hivatkozott szöveg. Tehát Újfalvinál a legtöbb esetben már azonos az ének és a nótajelzésként megadott szöveg metruma. Az 1602-es énekeskönyv nótajelzési szokásaira az is jellemző, hogy annak ellenére hoz új nótát, hogy

\footnotetext{
${ }^{259}$ A bártfai kiadások ebben az esetben pont az 1574-es és az 1582-es kiadások nótajelzését hozzák, míg az előző példában a debreceni vonalat vitték tovább. Ebből is látszik, hogy a kiadásoknál nem a szoros másolás, átvétel, hanem a gyülekezet által ismert változatok játszhattak döntő szerepet.

${ }^{260}$ A későbbiekben még lesz arról szó, hogy az 1632-es kolozsvári kiadás a nótajelzéseket következetesen újragondolja, rendszerezi, s itt is ezt figyelhetjük meg. Ez a nótajelzés Szegedi Gergely énekét takarja, ld. RPHA 1024.
} 
addig is volt kotta és/vagy nótajelzés az előző kiadásokban. Újfalvi a korábbi históriás énekekre való hivatkozásokat minden esetben kicseréli olyan gyülekezeti énekre, amely a korban ismert volt, több kiadást megélt. Tendencia-szerüen látszik érvényesülni, hogy a nótajelzéseket ismert, a korpuszon (gyülekezeti énekeken) belüli dimenzióba helyezi, és az előszavában más, nem templomi használatra szánt énekek nótajelzésként való hivatkozását elhagyja. Az 1602-es debreceni kiadás előszavában Újfalvi Imre közvetve, a teljes magyar zsoltárfordítás hiánya mellett kitér az éneklésre, a dallamok minőségére, minősítésére is. Az egyik ilyen hely, amikor a psalmusokról beszél. Itt az első fogyatkozásnak a teljes magyar psaltérium hiányát említi, mégpedig a következő módon:

„elsö, hogy még ilyen módon az egész Psaltérium nincsen ez sok Énekestül-is Magyar Ritmusokban rendeltetvén: egy pediglen sok képpen is találtaték. "261

Ezt a részt annak alátámasztására szokás idézni, hogy Újfalvi Imre, noha egy Bogáti Fazakas-zsoltárt bevesz az énekeskönyvébe (ez a Mely hatalmas a mi Urunk, az Isten... ${ }^{262}$ kezdetü ének), mégis hiányolja a teljes magyar zsoltároskönyvet, így feltehető, hogy nem tudott Bogáti zsoltárkönyvének teljességéröl. ${ }^{263}$ A többi, az éneklésre való utalást figyelembe véve nem tarthatjuk azonban azt sem kizártnak, hogy Újfalvi tudott Bogáti Fazakas Psaltériumáról, csak a „magyar ritmusokkal” volt esetleg problémája. Bogáti Fazakas zsoltárai közül ugyanis a legtöbb olyan metrumban íródott, amely igen ritka volt a 16. században. Volt tehát magyar zsoltárkönyv, de nem többségében gyakori, „magyar ritmusban”. Egyébként az a zsoltár, melyet Újfalvi bevesz, éppen olyan metrumú, amely igen gyakori a 16. században, tehát talán nem okozhatott nagy problémát az éneklés terén. ${ }^{264}$

Újfalvi előszava a zsoltárok kapcsán azt is problémásnak látja, hogy számos zsoltár eltér a bibliaitól, s mindenféle „preafatioval” és „conclusioval” illetik a zsoltárokat. Ács Pál meg is jegyzi, hogy Újfalvi énekeskönyve az első, amely következetesen kiszedi a keletkezésre utaló kolofonstrófákat a zsoltárokból - ez is tudatos szerkesztési elve tehát. ${ }^{265} \mathrm{Az}$ utolsó problémaként ismét a ritmusra tér ki a zsoltárok kapcsán Újfalvi: „Utolsó, hogy sokban semmi mesterséggel való ritmus nincsen." 266 A zsoltárok ritmusával is gond van tehát. A

\footnotetext{
${ }^{261}$ H. HuberT, i.m., 393. (Modern átiratban idézem itt is, a továbbiakban is.)

262 RPHA 877.

263 Így érvel például H. HuberT, i.m. 146, 160. lábjegyzet, és KLANICZAY TIBOR, Újfalvi Imre és az 1602. évi énekeskönyv = Reneszánsz és barokk, Bp., 1961, 165.

${ }^{264}$ A Mely hatalmas... kezdetü Bogáti Fazakas-zsoltár a11 a11 a11 a11-es metrumú, s ebben a metrumban a 16. század során 167 szöveg volt ismeretes az RPHA alapján.

265 Ács PÁL, ,Tiszta énekek” - Újfalvi Imre: Keresztyéni énekek (1602) = „Elváltozott idők”, Bp., Balassi, 2006, 57.

${ }^{266}$ H. HuBERT, i.m., 394.
} 
ritmuson kívül az énekléssel, énekelhetőséggel kapcsolatban is többször véleményt nyilvánít: [v]étkeznek azért, [...] akik akármi bokorban költött éneket mindjárást a templomba vittenek, és még mostan is visznek, s valami pajkos, vagy hajdú nótára elmondanak: söt efféléket énekelnek inkább, hogynem mint a Psalmusokból vétetett éneket. ${ }^{267}$ Később az előszó arra is kitér, hogy bizonyos énekeket nem csak az „illem”, a nem odavalósága miatt hagy ki a templomi énekek közül, hanem azért is elvesz az előző kiadások anyagából, mert a gyülekezet többnyire szokásból énekel, nem „,betüből”, s ezt a szokást, a megszokott anyagot kívánja nyomtatásban is megjelentetni, mert a fó célja, hogy a gyülekezet együtt énekeljen. Ez a rész már egyértelmüen utal arra, hogy 1602-re a közismertségnek olyan fázisában járnak a gyülekezeti énekek, amikor a „község” szokásból és gyakorlásból énekel, és a gyülekezet gyakorlatát egy énekeskönyv-szerkesztőnek figyelembe kell vennie. „S ha a szokást nem néztük volna, amint ide fel is mondám, némelyeket ezek közül is kihagytunk, s helyben másokat tettünk volna, amint egynéhányban cselekedtünk is, annyira akarnók hogy a község is gyakorlásból és szokásból, ha a betüböl, - mint egyéb nemzetek között - nem lehet, mindeniket értené, és velünk együtt mondaná. Néha még a tanitók is az újságért nem értik, mit mond a kórus. "268

A gyülekezeti igények figyelembevételével ugyan, de a Szentírástól távol álló, és bármiféle világi dallamra éneklendő zsoltárokat Újfalvi elveti. Ez lehet az oka annak is, hogy egyrészt igyekszik a korábban históriás énekek nótájára éneklendő szövegekhez a világi vagy bibliai tárgyú história helyett a gyülekezeti énekekből nótajelzést hozni. Erre példa a Minden állat dicsér, Úristen... (RPHA 952) incipitű zsoltár nótajelzése, mely az 1574-es komjáti, az 1582-es detrekői, az 1590-es debreceni, az 1593-as bártfai, sőt, az 1602-14 közötti bártfai énekeskönyvben is a „Cyrus éneke nótájára” utal. Újfalvi Imre 1602-es kiadása az Astiages és Cyrus történeti témájú históriája helyett (RPHA 525) az Irgalmazz, Úristen... kezdetü (RPHA 590) éneket hozza. Tehát annak ellenére, hogy a szótagszám azonos minden esetben, Újfalvi - és nyomában az 1602-15 közötti, illetve az 1632-es és 1697-es unitárius énekeskönyvek - lecseréli a nótautalást, s történeti história helyett a gyülekezeti énekekből keres nótajelzést. Látható, hogy ez az előszóban leírtaknak megfelelő kiadói változtatás, amit nem fog követni például az 1602-14 között Bártfán megjelent énekeskönyv.

A lecserélt nótajelzések másrészt az 1602-es debreceni kiadásban minden esetben igyekeznek a pontos szótagszámot követni. Ezt fentebb láttuk például az Aki veti segedelmét... (RPHA 74) esetében is. A korábban latin nyelvü incipitre utaló nótajelzések

${ }^{267}$ H. HUBERT, i.m., 395. 
cseréjének az oka egyrészt nyilván az, hogy a kialakult magyar énekkorpuszt a 17. század elejére a gyülekezetek már jobban ismerik, mint a latin nyelvü bibliai incipiteket, másrészt pedig a nótajelzések lecserélésében az is közrejátszhat, hogy a korai protestáns énekeskönyvekben található kotta és/vagy nótajelzés gyakran problémát okozhatott az elhangzáskor. Az 1636-os krakkói ${ }^{269}$ evangélikus énekeskönyv-töredékekből ismert, Gálszécsi István által írott előszóban az olvasókhoz olyan, a kottás énekeskönyv használatához írott útmutatás található, amelyben a szerkesztő maga is elismeri, hogy a kották és az énekek nem fedik egymást szótagszám alapján, $\mathrm{s}$ emiatt minden éneket „,megvirgulált. ${ }^{, 270}$ A megvirgulálás Csomasz Tóth Kálmán értelmezésében azt jelenti, hogy a hosszabb sorok többlethangjait megismételve aprózzák, és több szótagot énekelnek ugyanarra a hangra. $^{271}$

Csomasz Tóth kifejti, hogy a hangjegyekkel rögzített dallam sok esetben csak „körülbelüli keretül” szolgált, „mert versszakonként és soronként előfordulhatott, sőt ismételten elö is fordult, hogy a szövegben fellépö szótagszaporitások miatt egyik-másik hangot meg kellett ismételni vagy aprózni, majd pedig a rövidre sikerült sorokban egyes dallamhangok összevonásával melizmákat kellett alkotni."

Bár a kotta-szótagszám összefüggésről Huszár Gál az előszavaiban (1560, Óvár és 1574, Komjáti) nem ír, ennek ellenére ezekben a kiadásokban is többször találkozunk nótajelzés-dallam-metrum tekintetében problémákkal. A régi magyar dallamokhoz, a zenetörténethez egyáltalán nem értve erről a dolgozat csak annyit mer bizonyossággal állítani, hogy a „megvirgulálás”, az elaprózás vagy a szaporítás talán itt is gyakorinak számított még.

Az Emlékezzél, Úristen, híveidröl... kezdetű könyörgéshez (RPHA 368) az 1574-es komjáti kiadás a Légy irgalmas... kezdetü Szegedi Lajos-éneket (RPHA 834) rendeli nótajelzésül. $^{273}$ A könyörgés metruma a11 (4,7); a11 (4,7); a11 (4,7); a11 (4,7), a nótajelzésként hivatkozott éneknek azonban minden sora egy szótaggal rövidebb, - a10 $(4,6)$; a10 (4,6); a10 (4,6); a10 (4,6) - így valószínü, hogy ennek az éneknek a dallamára csak akkor tudták ráénekelni, ha az egyik hangra két szótagot énekeltek.

A Megbántunk, Isten, szüntelen tégedet... (RPHA 859) kezdetü könyörgéssel ugyanez a helyzet: az a11(5,6); a11 (5,6); a11 (5,6); a11 (5,6)-os metrumú ének nótajelzése az 1574-es

\footnotetext{
${ }^{269}$ RMNy 18.

${ }^{270}$ H. HUBERT, i.m., 325.

${ }^{271}$ CsOMASZ Tóth Kálmán, A prágai Gálszécsi-töredék énekei, ItK, 1970. 51-59. (57)

${ }^{272}$ CSOMASZ TóTH i.m. 56-57.

273 Szintén ez szerepel nótajelzésként az 1582-es detrekői kiadásban is. A többi kiadás egészen az 1632-es unitárius énekeskönyvig nem rendel a könyörgéshez nótajelzést, itt viszont a Csak tehozzád, szent Atyánk... kezdetű ének (RPHA 224) szerepel, amelynek a metruma már azonos a szóban forgó énekével.
} 
komjáti első megjelenésétől kezdve az 1582-es detrekői, az 1593-as és az 1602-14 közötti bártfai énekeskönyvekben is a Boldogok azok, kik Istent félik... (RPHA 207). Ennek a metruma viszont egy szótaggal kevesebb az első három sorban, és csak a negyedik sora azonos a Megbántunk, Isten ... kezdetű énekével: a10 (5,5); a10 (5,5); a10 (5,5); a11 (5,6). Itt is, mint azt az előzőekben kifejtettük, Újfalvi Imre 1602-es debreceni énekeskönyve lesz az első, amely olyan nótajelzést rendel az ének mellé, ami a metrumában teljesen megegyezik azzal: a Boldog az olyan ember az Istenben... kezdetü ének (RPHA 0203) metrumképlete szintén 4x a11 (5,6)-os.

Az, hogy az 1574-es komjáti kiadásban nem mindig fedi a nótajelzés metruma az énekét, Huszár Gál által több helyen is jelölve van. Az Emlékezzél meg, Úristen... (RPHA $365)$ esetében a címben is jelölve van az ének és a hivatkozott nótajelzés közötti metrum különbség, a címe ugyanis Azon psalmus ez ritmussal rövidb versekbe szereztetett. A zsoltár előtt pedig az Ó Úristen, tekints hozzánk... kezdetű zsoltárparafrázis található (RPHA 1139), amely a8, a8, b8, b8, a8, a8, a8-as metrumú. Az Emléklezzél meg, Úristen... metrumképlete a16 (8,8); a16 (8,8); a8-as. Ezek szerint Huszár Gál értelmezésében az „,egy ritmus” ebben az esetben két nyolcassal, tehát 16 szótaggal rövidebbet jelent. Ugyanezt a címet átveszi a többi gyülekezeti énekeskönyv is, s először az 1590-es debreceni kiadás teszi hozzá a nótajelzésre utaló instrukcióhoz, hogy „,avagy Mi Urunk” [Jézus Krisztusnak]... Újfalvi 1602-es debreceni kiadása pedig már csak ezt hozza nótajelzésként, az „egy ritmussal rövidb verseket” nem említi. Igyekszik tehát szótagszám tekintetében pontosan megfelelő nótajelzést találni itt is. (A Mi Urunk... metruma: x8, x8, x8, x8, x8.)

Talán ebből a néhány példából is kitetszik, hogy az éneklés terén Újfalvi Imre 1602-es debreceni énekeskönyve már igyekszik kialakítani egy - ha csak lehet, - magyar nyelvü, a gyülekezeti énekkorpuszon belül nótajelzés-hivatkozási rendszert, amelyből a históriákra való hivatkozást kiveszi. Ez a rendszer pedig úgy tünik, hogy alapvetően a szótagszámon, a sorok osztatán alapul, nem feltétlen a kottás dallamokon.

Az unitárius kiadások nótajelzéseit illetően is megállapíthatunk tendenciákat. Az első énekeskönyvben (1602-15) a zsoltárrészben 65 zsoltár található, amelyből csak 24-nél van nótajelzés. A nótajelzések többsége nem a már korábban, a protestáns hagyományban rendszeresen jelenlévő énekeknél találhatók átvétele. A 24-bő1 21 olyan zsoltárparafrázisok előtt található, amelyek csak unitárius forrásban hagyományozódtak. Ezek közül tíz zsoltár a Papp Géza által azonosított lengyel (föként Kochanowski) ${ }^{274}$ zsoltárparafrázisok fordítása,

${ }^{274}$ PAPP Géza, Ismeretlen Kochanowski-forditások a XVI-XVII. századból, ItK, 1961, 328-340. 
melyek a Nota Polonica jelzés mellett szinte minden esetben tartalmaznak magyar nótajelzést is alternatívaként. Nyolc nótajelzéssel ellátott zsoltár pedig Bogáti Fazakas Miklósé, akinek a legtöbb zsoltára, mint azt már említettük, alig, vagy egyáltalán nem ismert metrumban íródott.

Az 1602-15 közötti kolozsvári kiadás zsoltárrészében tehát olyan parafrázisok előtt található nótajelzés, amelyek idegen mintára íródtak, és/vagy ritka metrumképlettel bírnak. S hozzá kell tennünk, ezek mind olyan szövegek, amelyek (szinte csak) unitárius forrásból maradtak ránk. Az énekeskönyv „szép külömb-külömb ájtatos dicséretek” részében 53 ének van, amelyből viszont csak háromnak van nótajelzése, s ez a három is olyan ének, amely csak unitárius környezetben hagyományozódik. ${ }^{275}$ A kötet vizsgált részeiben található összesen 27 nótajelzésből tehát mindegyik olyan ének előtt van, amely csak az unitárius korpuszon belül maradt fönn, s a zsoltárok esetében a metrum szokatlan volta is szerepet játszhat abban, hogy nótajelzést rendelnek melléjük. Ebből arra következtethetünk, hogy egyrészt a korábbi protestáns énekhagyományt az unitárius felekezet ekkorra már annyira ismeri, hogy nem szükséges nótajelzéseket tenni a szövegek fölé. Másrészt azt is logikusnak látszik feltételezni, hogy a „nagyközönség,” a befogadók számára ezek a nótajelzéssel ellátott szövegek most lesznek elérhetők először, hiszen az énekek számához képest elenyésző számú nótajelzések mindig olyan szövegeknél vannak a kiadásban, amelyek az unitárius hagyományban lesznek jelen $\operatorname{csak}^{276}$ a későbbiekben is. Így valószínűleg ezek az énekek a gyülekezetek számára eddig nem voltak ismertek, s emiatt kellett nótajelzést rendelni hozzájuk.

Az RMKT 17/4. kötetének jegyzete közvetlen érveket sorakoztat fel arra nézvést, hogy az 1632-es unitárius énekeskönyv szerkesztője a zsoltárszerző Thordai János lehetett. ${ }^{277}$ Egyetértve az RMKT állításával, a nótajelzés-használat tekintetében a gyülekezeti énekeskönyv anyagán kívül a Thordai-zsoltárok nótajelzéseivel is érdemes foglalkozni, hiszen utóbbiak szerzője az előbbi nyomtatvány szerkesztője, így feltételezhetjük, hogy szerzői/szerkesztői elvei azonos alapon nyugszanak.

Az 1632-es gyülekezeti énekeskönyv általunk vizsgált két részében összesen 148 ének van. A zsoltárrész láthatóan bővült az előző kiadáshoz képest: itt már 95 psalmus van, s ebből 78 énekhez nótajelzést is rendel a szerkesztő. Az előző kiadásokhoz képest a Sequuntur...rész is változást mutat: 53 énekéhez 39 nótajelzés tartozik. Látható tehát, hogy az 1602-15

${ }^{275}$ Az egyik a Bujdostában szent Dávid próféta... (RPHA 5027), melyet Toroczkai Máténak tulajdonítanak. A másik a Nagy hálákat az Istennek adjunk... kezdetü ének (az RPHA nem közli), a harmadik pedig a Jövel, légy velünk, Úristen... (RPHA 694).

${ }^{276}$ A Bogáti Fazakas-zsoltárok esetében ez természetesen a szombatosokra is érvényes.

${ }^{277}$ RMKT 17/4, 536-37. 
közötti kiadáshoz képest lényegesen megnő a nótajelzések használata, mondhatni, szinte minden ének kap nótautalást.

A nótautalások kapcsán már néhány példával szemléltettük, hogy az 1602-es debreceni kiadás sok esetben újít: új, de minden esetben egyházi énekekre cserél számos nótajelzést, s láthatóan figyel arra a szerkesztő, hogy a nótajelzés szótagszám szempontjából pontos, azonos legyen. Ehhez képest az 1632-es kiadás szerkesztője „tökéletesíti,” teljesen megvalósítja az 1602-es debreceni kiadás által már elkezdett rendszeresítést, rendszerezést. Egyre több énekhez csatol nótajelzést, s ezek a nótajelzések itt már minden esetben teljesen megegyező metrumú szövegre utalnak, melyek egyházi énekek. Sőt, az 1632-es kolozsvári kiadásban nagyon gyakori a nótajelzések tekintetében a keresztbeutalás, tehát az, hogy az egyik éneknél nótajelzésként hivatkozott szövegnek az énekeskönyvben az lesz a nótajelzése, amely másutt ezt hivatkozza nótajelzésként. Ilyen például az Aki az Istent megismerheti...(RPHA 68) és a Jer, emlékezzünk, keresztyén népek... (RPHA 645) esete, melyek az 1632-es kiadásban egymásra hivatkoznak nótajelzésként. De ugyanez áll a Bocsásd meg, Úristen... (RPHA 185) és a Láss hozzám, Úristen... (RPHA 825) 1632-es kiadásbeli szövegváltozatai esetében is: egymást hivatkozzák nótajelzésként. Ez a sok-sok keresztbehivatkozás olyannyira gyakori, és annyira egyértelművé teszi azt, hogy mely énekeknek egyezik meg a metrumuk szótagszám és osztat tekintetében, hogy a kiadás 260. lapján kezdődő Boldog az ilyen ember ö lelkében... (RPHA 202) kezdetű Szegedi Gergelyzsoltár címe és nótajelzése a kötetben a következő: Psalmus 112. Ugyanazon nótára. Előtte pedig a Boldog az ilyen ember az Istenben... (RPHA 203) áll, melynek a nótajelzése a Boldog az ilyen ember ö lelkében..., tehát a két egymást követő zsoltárnál utalásai miatt a kereszthivatkozás helyett már önmagára utal nótajelzésként egy zsoltár.

Úgy gondoljuk, ebből helytelen lenne arra következtetni, hogy a szerkesztő vagy a nyomdász nem figyelt a pontos nótajelzésekre. Ez sokkal inkább arra utal, hogy a kereszthivatkozással a szerkesztő rámutat az azonos metrumú énekekre, melyek dallamára feltehetően könnyedén énekelhetők a szövegek, de ezt a gyülekezet tulajdonképpen ismeri már annyira, hogy ne kelljen külső nótahivatkozásokkal megerősíteni, újabb alternatívákat a szövegek mellé írni. Ha a gyülekezet ilyen jól ismeri már a nótákat, akkor viszont felmerül a kérdés, hogy a szerkesztő mi okból igyekszik mindenhová nótajelzést írni. Az 1632-es kiadás esetében ennek magyarázata talán egy újabb érv amellett, hogy Thordai János volt az énekeskönyv szerkesztője. 
Thordai János 150 zsoltárának kritikai kiadását az RMKT 17/4-es kötete tartalmazza. $^{278}$ A zsoltárok forrásainak ${ }^{279}$ ismertetése mellett az RMKT jegyzetapparátusa azt is megemlíti, hogy Thordai János zsoltárainak nótajelzései „magyar, nagyrészt XVI. századi dallamokra íródtak, mindössze az 54. zsoltár készül idegen, lengyel dallamminta után."280 Ennek a dallamnak járt utána tanulmányában Papp Géza, s azonosított be egy Kochanowskizsoltárt forrásnak. ${ }^{281}$ A többi zsoltár, tehát 149, mind olyan nótajelzést tartalmaz az RMKT kritikai kiadása szerint - amely a Thordai-kódexet (S 80) veszi alapul, így a nótajelzéseket mi is eszerint hozzuk, - amely a 16. századi protestáns énekhagyományban, 17. század eleji unitárius énekanyagban megtalálható. Itt apró módosításra tehetünk javaslatot. Thordai, aki Bogáti Fazakas és Szenci Molnár Albert után harmadjára készíti el a teljes magyar verses zsoltárkönyvet, elődeivel szemben olyan nótajelzéseket hoz parafrázisaihoz, amely a gyülekezeti éneklésben ismert, megszokott éneket hivatkozik minden esetben. Említettük, hogy Bogáti Fazakas zsoltárainak többsége olyan metrumú, mely igen ritka a magyar költészetben. Szenci Molnár Albert „francia nótákra” szerzett szövegeiről ismeretes, hogy sokáig többen ellenezték a nehezen megtanulható, a magyar gyülekezeti éneklésben idegennek ható dallamai miatt. ${ }^{282}$ Thordai zsoltárfordításának egyik célja talán éppen az, hogy ismert, magyar metrumú énekekre írja meg a 150 zsoltárt, akár alternatívaként Szenci Molnárnak a magyar énekhagyománytól eltérő dallamaihoz. ${ }^{283}$ Noha Thordai fordítása nyomtatásban nem jelenik meg, ennek ellenére 1627-es keletkezésétől kezdve minden bizonnyal igen nagy népszerüségnek örvendett - legalábbis az unitáriusok között. Ezt

\footnotetext{
${ }^{278}$ Mivel a Thordai-életmű vizsgálata a dolgozat témájától messzire vezetne, így ennek részletezésétől, a szakirodalom ismertetésétől eltekintünk. Thordai János zsoltárainak forrásairól, a források leszármazási ágáról STOLL Béla ad részletes elemzést az RMKT 17/4. jegyzetében, ld.:572-599. A Thordai-zsoltárok elemzéséröl bővebben: VARGA Imre, Thordai János zsoltárainak forrásáról, manierizmusáról, ItK, 1968, 541-554. A Thordai-zsoltárokban fellelhető Rimay-hatásról ír ZENTAI Mária, Rimay hatás Thordai János zsoltáraiban, Acta Historiae Litterarum Hungaricarum, Tomus XIII. Szeged, 1973, 111-123.

${ }^{279}$ Számunkra elsősorban a legkorábbi források a fontosak, a Thordai-kódex és a második világháborúban megsemmisült Abrugyi György kézirata. Ennek anyagáról bővebben: DAMJÁN István, MKSz 1902, 159-161. (A kézirat leírása.) - KANYARÓ Ferenc, KerMagv. 1908, 270-4. (DAMJÁN cikkének helyesbítései.) - HEREPEI János, ErdM 1939, 277. - RMKT XVII/4, 580-1.

${ }^{280}$ RMKT 17/4. 580.

${ }^{281}$ PAPP Géza, Thordai János lengyel dallammintája, ItK, 1966. 208-210.

${ }^{282}$ Még Tótfalusi Kis Miklós az 1686-os kiadásában (RMK I. 1346.) is szerepel a panasz, hogy a kántorok és a tanítók sem ismerik elég jól a zsoltárok „francia” dallamát. (Idézi: H. HUBERT, i.m., 79.)

${ }_{283}$ Érdemes megemlíteni, hogy az Egyháztörténet szerint 1665 januárjától engedték a Szenci Molnár zsoltárokat (a kisebb!) unitárius templomban „szemelvényesen” énekelni. Az idézett részekben az Egyháztörténet arra is kitér, hogy Szenci Molnár mellőzésének oka elsősorban a sok ,átkozódó” szövegű zsoltár. (KÉNOSI-UzONI, i.m., 812-13.) Az ellenség gyülöletéről, a rágalmazásáról szóló részeket az unitárius nyomtatványok a korábbi protestáns hagyományban már meglévő szövegekből is kivették, vagy átalakították azokat. Jellemző például, hogy az ellenség megtörésének, levágásának kérése helyett „térítsd meg ellenségünket” jellegü szövegváltozatokat hoznak, de erről a későbbiekben bővebben lesz még szó. Úgy tűnik azonban, hogy az egyháztörténet szerint az 1660-as évekig az unitárius gyülekezeti éneklésbe semmiképp nem vették bele a Szenci Molnár-zsoltárokat.
} 
bizonyítja a számos kéziratos forrása, illetve bizonyos parafrázisainak a gyülekezeti énekeskönyvekbe való bekerülése. Az 1632-es énekeskönyv hét Thordai-zsoltárt tartalmaz. Feltünő viszont, hogy az 1602-15 közötti énekeskönyv 118 vizsgált énekéből 17-nek az 1632es kiadásban már Thordai-zsoltár a nótajelzése. ${ }^{284}$ Említettük, hogy az 1632-es kiadás ad sok éneknek új nótajelzést, ám a Thordai nótajelzések között olyanok is bőven vannak, amelyek nyomtatásban nem jelennek meg. Így valószínünek tünik, - mivel a nótajelzés alapvető funkciója az, hogy a gyülekezet számára ismert éneket adjon meg, amelynek dallamára énekelni lehet az adott szöveget is - hogy az 1627-ben elkészült 150 zsoltárt a gyülekezeti énekeskönyv kiadásával egy időben már rendszeresen használják, ha nem is széles körben, de a kolozsvári unitárius gyülekezetekben mindenképp.

Sőt, hozzátehetjük, hogy - bár az RMKT jegyzetei nem minden esetben adják meg, hogy a Thordai-zsoltárok nótajelzését melyik forrás alapján közlik, ez legtöbbször a Thordaikódex alapján történik - az a 17 ének, amely az 1632-es énekeskönyvben Thordait használ nótajelzésnek, ugyanúgy keresztbehivatkozás, mint a már említett pár példa az 1632-es gyülekezeti énekeskönyvben. A 17, az 1632-es gyülekezeti énekeskönyvben nótajelzésként hivatkozott Thordai-zsoltárnak a Thordai-kódexben éppen az a 17 ének a nótajelzése, amely a nyomtatványban meghivatkozza azokat. Ezeket az egymásra hivatkozó énekeket nem tartjuk feleslegesnek megemlíteni. Fontos, közös jellemző itt is, hogy a nótajelzések és az énekek minden esetben pontosan megfelelnek szótagszám tekintetében. ${ }^{285}$

\begin{tabular}{|c|c|}
\hline $\begin{array}{c}\text { 1632-es kiadás énekei - (A másik } \\
\text { oszlop azonos sorában a nótajelzésként } \\
\text { hivatkozott Thordai-zsoltárral) }\end{array}$ & $\begin{array}{c}\text { Thordai János zsoltára - (A } \\
\text { Thordai-kódexben a felsorolt zsoltároknak } \\
\text { minden esetben az 1632-es gyülekezeti } \\
\text { énekeskönyvnek a táblázatban azonos sorban } \\
\text { szereplö éneke a nótajelzése) }\end{array}$ \\
\hline Drága dolog az Úristent dicsérni... & $\begin{array}{c}\text { Pásztorom az Úr, aki mindent éltet... } \\
\text { RMKT 17/4. 78.sz. }\end{array}$ \\
\hline
\end{tabular}

\footnotetext{
${ }^{284}$ A 17 nótajelzésként hivatkozott Thordai-zsoltárból az 1632-es gyülekezeti énekeskönyvben megtalálható 3 zsoltár szövege is. 14 Thordaira utaló nótajelzés azonban olyan, amelynek a szövege nyomtatásban nem jelent meg.

${ }^{285}$ Mint említettük, az ismert protestáns gyülekezeti énekhagyomány metrumait használja fel Thordai a 150 zsoltár megírásakor. Varga Imre össze is számolja, hogy Thordai összesen 39 versformát alkalmaz a 150 zsoltárban. (ItK, 1968, i.m. 547.)
} 


\begin{tabular}{|c|c|}
\hline $\begin{array}{l}\text { Neked mondok dicséretet... (RPHA } \\
1063)^{286}\end{array}$ & $\begin{array}{l}\text { Szent Isten, téged dicsérlek... RMKT } \\
\text { 17/4. 156. sz. }\end{array}$ \\
\hline $\begin{array}{crc}\text { Nézz } & \text { mireánk, } & \text { Úristen, } \\
\text { kegyelmesen... (RPHA 1079) } & \end{array}$ & $\begin{array}{l}\text { Hajtsd meg füled, Úristen... } \\
\text { RMKT 17/4. 83. sz. }\end{array}$ \\
\hline $\begin{array}{l}\text { Dicsérd az Istent mostan, ó én } \\
\text { lelkem... (RPHA 251) }{ }^{287}\end{array}$ & $\begin{array}{l}\text { Szívem, vesém, szám, minden... } \\
\text { RMKT } 17 / 4.158 . \text { sz. }\end{array}$ \\
\hline $\begin{array}{l}\text { Ó, mennyei nagy boldogság... } \\
(\text { RPHA } 1123)^{288}\end{array}$ & $\begin{array}{l}\text { Úristen, engem itélj meg... } \\
\text { RMKT 17/4. 98. sz. }\end{array}$ \\
\hline $\begin{array}{l}\text { Szent Dávid próféta éneklö } \\
\text { könyvének... (RPHA 1309) }\end{array}$ & $\begin{array}{l}\text { Szeretlek tégedet édes atyám... } \\
\text { RMKT 17/4. 73. sz. }{ }^{289}\end{array}$ \\
\hline $\begin{array}{l}\text { Erös várunk nekünk az Isten... } \\
\text { (RPHA 392) }\end{array}$ & $\begin{array}{l}\text { Erös várunk az Úr és bástyánk... } \\
\text { RMKT 17/4. 101. sz. }{ }^{290}\end{array}$ \\
\hline 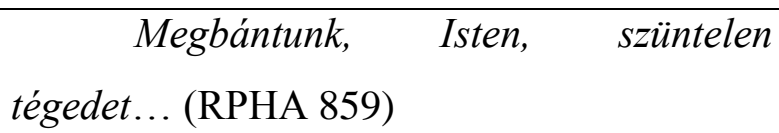 & $\begin{array}{l}\text { Hallgasd meg Uram az én } \\
\text { könyörgésem... RMKT 17/4.116. sz. }\end{array}$ \\
\hline $\begin{array}{l}\text { Úrnak szolgái, no, dicsérjétek... } \\
\text { (RPHA 1447) }\end{array}$ & $\begin{array}{l}\text { Úristen, te örökségedben... } \\
\text { RMKT 17/4. 134. sz. }\end{array}$ \\
\hline $\begin{array}{l}\text { Ó, mely igen rövid volt, lám, e világ... } \\
\text { (RPHA 1121) }\end{array}$ & $\begin{array}{l}\text { Bús szivemböl siralomra mozdulék... } \\
\text { RMKT 17/4. 132. sz. }\end{array}$ \\
\hline $\begin{array}{llll}\text { Mindenek meghallják és jól } & \text { ér } \\
\text { megtanulják... (RPHA 0968) } & & \end{array}$ & $\begin{array}{l}\text { Dicsérjétek Istent az ö szentségével... } \\
\text { RMKT 17/4. 206. sz. }\end{array}$ \\
\hline $\begin{array}{l}\text { Csak tebenned, Uram Isten... } \\
\text { (RPHA 0222) }\end{array}$ & $\begin{array}{l}\text { Boldog és áldott vagy, aki... } \\
\text { RMKT 17/4. 183. sz. }\end{array}$ \\
\hline $\begin{array}{l}\text { Felséges Isten, mennynek, földnek } \\
\text { ura... (RPHA 0411) }\end{array}$ & $\begin{array}{l}\text { Életét aki undok bünben éli... } \\
\text { RMKT 17/4.91. sz. }\end{array}$ \\
\hline
\end{tabular}

${ }^{286}$ Ez a Bogáti Fazakas-zsoltár is csak unitárius (és szombatos) forrásból ismert a vizsgált korszakból, ezért is egészítettük ki az RMKT azon állítását, hogy Thordai zsoltárai 16. századi magyar gyülekezeti énekekre utalnak azzal, hogy főleg olyanokra, amelyek az unitárius énekhagyományban bevett, megszokott, ismert énekek lehettek.

${ }^{287}$ Ennek az éneknek egyébként, noha az 1579-es debreceni kiadástól (RMNy 429) kezdve a nyomtatott hagyomány része, az 1632-es unitárius gyülekezeti énekeskönyv ad elöször nótajelzést.

${ }^{288}$ Az 1593-as bártfai evangélikus (RMNy 713) kiadásban jelenik meg először nyomtatásban, de nótajelzést az 1632-es kolozsvári kiadás ad először. A számos első nótajelzés-adás jól mutatja, hogy ez a szerkesztőnek, Thordainak minden bizonnyal célja volt: ahol csak lehet, tud, nótát is rendel a szövegek mellé, mely nóták azonos metrummal, de legalábbis azonos szótagszámmal bírnak.

${ }^{289}$ Megvan az 1632-es énekeskönyvben is.

${ }^{290}$ Itt Thordai arra a metrumra írja zsoltárparafrázisát, amelyre az ismert parafrázis is íródott, tehát a 46. Thordaizsoltár a 46. zsoltár ismeretlen szerzőtől származó parafrázisának metrumát követi.

${ }^{291}$ Megvan az 1632-es énekeskönyvben is. 


\begin{tabular}{|c|c|}
\hline $\begin{array}{cccc}\text { Mint kívánkozik a szarvas a } & \text { a } \\
\text { kútfejekhez... (RPHA 0996) } & & & \end{array}$ & $\begin{array}{l}\text { Igazlátó, szent Úristen... } \\
\text { RMKT 17/4. 199. sz. }\end{array}$ \\
\hline $\begin{array}{l}\text { Tekints reánk immár, nagy Úristen... } \\
\text { (RPHA 1368) }\end{array}$ & $\begin{array}{l}\text { Mint a hévség miatt megepedett... } \\
\text { RMKT } 17 / 4 .\end{array}$ \\
\hline $\begin{array}{l}\text { Segítségül hívjuk a mennybéli } \\
\text { Istent... (RPHA 1215) }\end{array}$ & $\begin{array}{l}\text { Istennek áldása az olyan emberen... } \\
\text { RMKT } 17 / 4.96 . \mathrm{sz.}\end{array}$ \\
\hline $\begin{array}{l}\text { Unszol minket (Int most minket) } \\
\text { Dávid próféta... } \\
\text { (RPHA 1417) }\end{array}$ & $\begin{array}{l}\text { Teljes szívböl akik bíznak... } \\
\text { RMKT 17/4. 180. sz. }{ }^{293}\end{array}$ \\
\hline
\end{tabular}

Praktikus megoldásnak tünik, hogy a nyomtatványban gyakran használnak Thordaizsoltárt nótajelzésnek, hiszen a keresztbehivatkozás által világossá válhat, hogy mely Thordai-zsoltár milyen dallamra van írva. Így ha a templomban csak kéziratos formában volt is meg a Thordai-psaltérium, a hívek számára a nótajelzések egymásra való folyamatos reflektálása segítette a nóták megjegyzését, hiszen a Thordai-zsoltárok nótái számukra ismert, rendszeresen énekelt szövegek voltak. ${ }^{294}$

Thordai az unitárius gyülekezetben használt énekek metrumait használta fel zsoltáraihoz, s ez, - bár témánktól kicsit eltér - mégis azt sejtteti, hogy Szenci Molnár Albert zsoltárait valóban igyekeztek nem bevenni az unitárius éneklésbe, hanem énekeltek helyette más, saját, de nyomtatásban meg nem jelent zsoltárokat. Az viszont, hogy egy gyülekezeti énekeskönyv nyomtatásban nem megjelent szövegeket használ tömegesen nótajelzésként, egyértelmüen megmutatja, hogy attól, hogy valami nem lett kinyomtatva, mindennapos használatban lehetett a 17. századi gyülekezeti éneklésben.

A Thordai-zsoltároknak ezt az ismert, magyar nyelvü unitárius gyülekezeti éneklés szerves részét képező szövegek nótájára, a metrumok pontos betartásával írott voltát a modern irodalomtörténet kevéssé hangoztatja, de a kortárs vagy közel kortárs irodalmi szempontból müvelt személyeinek ez el- és felismert tény volt. Erről tanúskodik a Kövendi János-kódexbe

\footnotetext{
${ }^{292}$ Nyomtatott hagyományban 1560-tól (ekkor kottával) meglévő szöveg, ennek ellenére nótajelzést az 1632-es kiadás ad elöször.

${ }^{293}$ A zsoltár megvan az 1632-es énekeskönyvben is.

${ }^{294}$ Azt sem szabad elfelejtenünk, hogy Thordai a kollégium tanáraként nyilván már igen hamar, a megírás után oktatni kezdet diákjainak a zsoltárokat, így azokat a kórus keletkezésük után nem sokkal már ismerhette.
} 
$(1679)^{295}$ Felvinczi György által a Thordai-zsoltárok elé (Balassi-strófában) írott versének a Thordai-zsoltárok megformáltságára és tartalmára reflektáló strófája is: ${ }^{296}$

Ha nézed értelmét,

jobbat annál elmét,

nem tudom, hogy kivánhatsz,

ritmusira tekints,

azokban hiba nincs,

bennek ki nem is hányatsz.

Nótájuk szép, kellö,

mindeniknek illö,

kit ha böcsmélsz,

megbánhatsz.

\section{I. 2. A nótajelzések használatában bekövetkező változások összegzése}

Azt már a címeknél is láttuk, s a továbbiakban is látni fogjuk, hogy teljesen, száz százalékban igaz és érvényes állításokat a gyülekezeti énekgyüjtemények szövegeinek, apparátuskészletének változásában nem tudunk megfogalmazni, hiszen mindig lesznek vagy felekezetre, vagy énekeskönyv-szerkesztőkre, vagy egyes énekekre érvényes kivételek. Az tendenciának látszik viszont a nótajelzések tekintetében, hogy noha a 17. század elejére kottával együtt nyomtatásban megjelenő gyülekezeti énekek nem lesznek, a nótajelzés használata egyre gyakoribbá válik. A 17. század elejétől ezek az egyre gyakrabban megjelenő nótajelzések szinte mindig a magyar nyelvü gyülekezeti énekköltészeten belüli, a templomi használatban lévő énekekre hivatkoznak, s a históriákra való nótautalás egyre ritkábbá válik. $\mathrm{Az}$ is tendenciának tünik, hogy a nótajelzés igyekszik minden énekhez metrumban, de legalábbis szótagszámban azonos éneket hozni.

\section{I. 3. Az apparátuskészlet, a paratextusok gyülekezeti énekgyüjteményen belüli változásának összegzése}

Az előző fejezetekben - a fontosnak vélt kitérések mellett- igyekeztünk példákkal szemléltetni azt, hogy a nyomtatott gyülekezeti énekhagyomány apparátuskészlete hogyan

\footnotetext{
${ }^{295}$ Közzétette VÁRfalvi NAGY János, Az unitáriusok énekeskönyveiröl, KerMagv., 1871, 120; majd SZABÓ T. Attila, Adatok Felvinczi György életéhez és irodalmi munkásságához, ItK, 1933, 144.

${ }^{296}$ Idézi PAPP Géza, i.m., ItK, 1966, 210.
} 
változott a 16. század közepétől a 17. század elejéig. Néhol a relevánsnak vélt 17. század közepi-végi unitárius énekgyüjtemények alakulására, és a kéziratos protestáns énekgyüjteményekre is kitértünk.

Ezek alapján már - bár kivételekkel minden esetben tarkított, de - a bemutatott példák, mennyiségi adatok alapján talán joggal tendencia-szerünek mondható állításokat tehetünk.

A 17. század elejére a protestáns gyülekezeti énekgyüjtemények egyre egyszerübb szerkezetüek, aminek az okát abban kereshetjük, hogy az ilyen jellegü énekgyüjtemények egyre elterjedtebbek lettek, egyre több ember kezében fordultak meg, így fontos volt, hogy a használatukat egyszerüsítsék. Az unitáriusok által bevezetett ábécérend kiválóan kielégíthette a gyüjtemény használóinak igényét, hiszen a liturgikus rend vagy a zsoltárszám helyett incipit alapján sokkal könnyebben megtalálhatták az adott, éppen éneklendő szöveget.

A zsoltárok esetében feltünő, hogy az 1602-15-ös kolozsvári kiadás megjelenésére már (egy kivétellel) teljesen kikopik a Vulgata-féle számozás használata, és a protestáns számozás bevetté válik.

Az egyéb gyülekezeti énekek címadási szokása is megváltozik: lényeges egyszerüsödés figyelhető meg. Ennek oka valószínüleg az, hogy a nyomtatott énekeskönyvek elterjedésével, a protestáns énekek több generációs ismeretével és terjedésével a gyülekezet tagjai már jól ismerik a szövegeket, és jól tudják, mi micsoda, miről szól, és mikor kell azokat énekelni. Emiatt nincs szükség bővebb magyarázatokra, amelyek addig a címekben bőségesen fellelhetők voltak. ${ }^{297}$

A periférikusan már megemlített tény, hogy Újfalvi Imre 1602-es debreceni énekeskönyve már egyetlenegy, a klasszikus értelemben vett kolofonstrófát sem közöl, arra enged következtetni, hogy a 17. század elejére a gyülekezeti énekek egyre inkább közköltészetiesednek. Mivel mindenki használja és énekli őket, nincs már szükség az 50-60 évvel azelőtti dátumot, a szerző vagy a megrendelő nevét és aktuális élethelyzetét taglaló strófára.

\footnotetext{
${ }^{297}$ A bővebb magyarázatok szükségtelenségét a címek rövidülése kapcsán H. HuBERT Gabriella is említi. (i.m. 111.) A „Más” feliratú (hol elválasztó funkcióval, tagoló egységként való szereppel, hol az előző énekhez tartalmilag kötődést jelölő funkcióval bíró) címek elszaporodásának általa írott másik magyarázatával viszont nem feltétlenül értünk egyet, H. HUBERT Gabriella szerint ugyanis ez a tény az ,igénytelen tömegtermelést” is jelzi. (i.m. 111.) Igyekeztünk rámutatni arra, hogy a kisebb közösségek gyülekezeti használatára szánt kéziratos másolatok is gyakran élnek a „,Más” elválasztó funkció használatával, a címeket igen gyakran elhagyják. Ezeket a kéziratos énekgyüjteményeket nyilván a mutatkozó igény, a kisebb városok gyülekezeti énekeskönyv-hiánya miatt kellett elkészíteni. Ha pedig ilyen vállalkozásba kezdtek, nyilván nem lustaságból, hanyagságból hagyják el a címeket. Ugyanez feltehetően igaz a nyomtatványokra is: ha nótajelzést adnak, gyakran újabbat is, mint az előző kiadások, akkor talán nem indokolt az ,igénytelen tömegtermelésre” visszavezetni a címadás elmaradását.
} 
Amellett, hogy a bizonyos paratextusok (jelen esetben a címek és a kolofonok) eltünése a közkinccsé, közismertté, mindenki által énekelt szöveggé válásról tanúskodik, talán arra is gondolhatunk, hogy ezáltal a szerkesztők az egyes énekek jobb, több helyzetben való alkalmazhatóságát akarták erősíteni. A címek legtöbbször alkalomra, funkcióra, élethelyzetre utaltak, ahogyan azt láttuk, s a kolofonstrófák is gyakran tartalmaznak a megírás körülményére, az ének keletkezésének, az elmondásának vagy leírásának okára utaló élethelyzeteket. (Rabságban, nyomorúságban, jó kedvben stb. írta a szerző.)

$\mathrm{Az}$ apparátuskészlet változása már mutatja a gyülekezeti énekek ismertségét, az énekeltségben is létező voltukat. A címek egyszerüsödése és/vagy eltünése is arra utal, hogy az énekgyűjtemény használói már tudják, mit mikor kell énekelni. A szótagszám egyezésén alapuló nótajelzések rendszeressé, de legalábbis egyre gyakoribbá válása pedig talán a feltehetően burjánzó, a szó nem éppen a legjobb értelmében sokszínű, „összevissza” éneklés megszüntetésének szándékával kezdődik el.

Ez a használatban, hangzó szövegen alapuló ismeretben gyökerezö, - s éppen emiatt a közköltészeti alkotásokkal is párhuzamba állítható - gyülekezeti énekhagyomány és a szerkesztők rendszerező, normatív szándékú, stabilizálni kívánó attitűdje az, amely a nyomtatott gyülekezeti énekeskönyvekben tetten érhető a 16-17. századi anyagban. Ez a kettősség fog látszódni a verses szövegek metrikai, retorikai és egyéb poétikai változásának alaposabb szemügyre vétele során is.

\section{II. A gyülekezeti énekek szövegének változásai: néhány megfigyelés}

Az alábbi példák elsősorban azokat a szövegváltozatbeli eltéréseket kívánják megmutatni, amelyek bizonyos tekintetben eltérnek a stemmával pontosan ábrázolható szöveghagyománytól. Az ilyen jellegű változásoknak egy részéért feltehetően az énekeltségben élés, a szóbeliségben való terjedés a felelős, míg mások a szerkesztő-kiadó javítási szándékait tükrözik. Mára nehezen rekonstruálható, hogy a sajátos - az énekelt, a nyomtatott és a kéziratosan terjedő - gyülekezeti énekhagyomány mely változása milyen okoknak tudható be, mindenesetre bemutatunk néhány olyan példát, amely úgy tűnik, a gyülekezeti énekek szövegváltozásaira jellemzőnek mondható a 16. század vége felé, a 17. század elején. 


\section{II. 1. A kolofon}

A kolofonokat érintő változásokkal érdemes kezdeni a szövegváltozások okait tárgyaló fejezetet, hiszen a kolofon bizonyos értelemben átmenetet képez a szövegek apparátuskészlete és a szoros értelemben vett szöveg között. Az apparátuskészlet részének tekinthetjük abban az értelemben, hogy a címhez, a szerző nevéhez vagy a nótajelzéshez hasonlóan kifelé mutat a szövegböl: a referenciális keletkezési okokat, alkalmakat, szerzőt vagy épp a dátumot és a helyszínt ismerteti. Ugyanakkor a szöveghez tartozik, hiszen annak szerves részeként, a befejezéseként összegzi, hogy az adott szöveg milyen indíttatásból készült, s így ha a szöveg nem lenne, magára a kolofonra sem lenne szükség. Úgy gondoljuk, e kettős létmódja miatt érdemes ezt a szövegváltozásoknál, de az apparátuskészletre is tekintettel tárgyalni.

Ahogyan arra már az előző fejezetben is utaltunk az Aki az istent megismerheti... kapcsán (RPHA 68), a 16. század legvégére, a 17. század legelejére megfigyelhető, hogy a klasszikus értelemben vett kolofonok, melyek a szereztetésre és/vagy annak helyére, idejére vagy személyére utalnak, fokozatosan kikopnak, s helyüket az ének tartalmát összegző jellegü strófák kerülnek. Némely ének esetében ez doxológiát tartalmaz, a zsoltároknál pedig főleg a zsoltárra mutató hivatkozó strófa jelenik meg.

A Nagybáncsai Mátyás akrosztichonú, Ne hagyj elesnem, felséges Isten... kezdetü zsoltárparafrázis (RPHA 1052) kolofonstrófája csak az unitárius forrásokból kopik ki: sem a nyomtatványok, ${ }^{298}$ sem a Csonka antifonálé nem hozza. Megvan viszont az 1579-es első megjelenésétől kezdve (1579, Debrecen) az 1582-s detrekői kiadásban; az 1590-es debreceniben; az 1593-as bártfaiban és az 1602-14 közötti bártfaiban az alábbi kolofonstrófa:

Született után ezerötszázban és a hetvenötben, / pünkösd havának elsö hetében szerzék ezt versekben:/ a nagy Istennek könyörög ígyen keserüségében.

Az unitárius kiadások annak ellenére sem hozzák a referenciális záró strófát, hogy ezáltal az akrosztichon csonkul: a Mátyás $s$-se kikopik.

A kolofonstrófák kikopásának fő okát talán abban érdemes keresnünk, hogy a gyülekezet által a templomban énekelve nincs már szükség az ének szerzőjére, annak keletkezési helyére is idejére, hiszen a közösség már magáévá tette az éneket, így a konkrét

\footnotetext{
${ }^{298}$ Kolozsvár, 1602-15 (RMNy 983); Kolozsvár, 1623 (RMNy 1290, elveszett, így csak a többi forrásból való hiány miatt feltételezzük, hogy nem volt meg benne); Kolozsvár, 1632, (RMNy 1541); Kolozsvár, 1697 (RMK I, 1503).
} 
személyesség feleslegessé válik. Még az ilyen, ehhez hasonló E./1-es szövegek esetében is látható, hogy ha sokáig része a protestáns nyomtatványoknak, akkor a kolofon kikopik, az E./1. számú beszélő bárki lehet, aki olvassa, énekli a szöveget. A kolofon kikopása tehát az általánosítás, a gyülekezetiesedés folyamataként írható le.

Ugyanígy megfigyelhető a Dóczi Ilona nevére írott ének esetében is (Dicsérlek tégedet, én édes Istenem... RPHA 281), hogy az unitárius forrásokból kikopik a kolofonstrófa, sőt, a záró versszak előtti, de a szereztetésre utaló versszak is eltünik az 1697-es kiadásból, nemcsak a kolofon. Az utolsó versszak azért is vet fel érdekes kérdést, mert annak ellenére, hogy megvan az 1582-es detrekői, illetve az 1593-as és az 1602-15 közötti bártfai kiadásban, különböző évszámot jelölnek meg a szereztetés idejeként: az 1582-es detrekői szerint 1567ben íródott az ének, az bártfai kiadások szerint pedig 1570-ben. A Vasady-kódex szövegváltozata a Dézsi-hagyaték alapján már az ezerötszáz helyett is ezerhatszázat ír.

Aki ez éneket rendelé versekben, gondolkodik magában, mert nincs bizodalma senkihez e földön ${ }^{299}$, sok nyomorúságában ${ }^{300}{ }^{301}$

[Az ezerötszázban ${ }^{302}$, hetven ${ }^{303}$ esztendöben ${ }^{304}$, pünkösdnek elmúltában, a kegyes Istenhez ${ }^{305}$ gondolatjában vagyon hálaadásban. $]^{306}$

Azt is megfigyelhetjük, hogy a személyes hangnemü énekek esetében a 17. század elejére még az unitáriusoknál is csak akkor kopik ki a kolofon, ha az adott ének előtte nyomtatványban és kéziratos formában is hagyományozódott, tehát ismertté vált, énekelték, másolták. Azokból a személyes hangvételü, feltehetően valóban magánhasználatra és/vagy magáncélra íródott énekekből, melyek a 17. század elejére még nem rendelkeztek nagyobb ismertséggel abban a tekintetben, hogy rendszeresen másolták és kiadták volna őket, nem feltétlenül kopnak ki a kolofonstrófák. Ide sorolhatjuk a Ládonyi Sára nevére írott Láss hozzám, Úristen... kezdetü énekét (RPHA 825). Minél több nyomtatványban, kéziratban megvan egy szöveg, annál valószínübb, hogy a 17. század elejére kikopik a kolofon. S úgy tűnik, a kolofon kikopása a gyülekezetiesedést szolgálja.

\footnotetext{
299 nincsen e földön neki bizodalma: : Vasady-kódex.

${ }^{300}$ nagy keserüségében: Bölöni-kódex.

nagy sanyarúságában: Vasady-kódex.

${ }^{301}$ hiányzó strófa: 1697 Kolozsvár.

302 ezerhatszázban (elöbb ötszáz, majd az lehúzva): Vasady-kódex,

${ }^{303}$ hetve - majd a lapszélen kiszakítva, Dézsi eddig idézheti, $n$ nélkül: Vasady-kódex.

304 és az hatvanhétben: 1582 Detrekő.

305 jó: Vasady-kódex.

${ }^{306}$ Az 1593-as bártfai kiadás alapján hozom, az unitárius változatokban nincs meg ez a strófa, a Bölöni-kódexben sem. Ott helyette a következő doxológia van: Dicsőség tenéked kegyes Atya Isten, mennynek, földnek Istene, ki élsz és uralkodol te dicsöségedben most és örökké, Amen.
} 
A gyakori énekeltség, ismertség tehát a referenciális jegyek elhagyását eredményezi. Jó példa erre a Szegedi Gergelynek tulajdonított, Németi Ferenc nevére írott zsoltárparafrázis, ${ }^{307}$ az Úristen, légy most mivelünk... is (RPHA 1439). Utolsó strófája 1569es debreceni első nyomtatott megjelenésétől kezdve az 1582-es detrekői kiadásig tartalmaz évszámot is, amely a későbbi kiadásokból már kikopik. Ez a személyes ének ezáltal szintén elveszít legalább egy, a szereztetés szempontjából lényegesnek tünő adatot.

Szent Dávid a zsoltárkönyvben,/ Absolon fia elött futtában, lígy könyörge, mint írván vagyon hetvenegyik részében. ${ }^{308}$

\section{II. 2. Az éneklő személye: E./1. és T./1.}

A gyülekezeti ének müfaji sajátossága, hogy a templomban a hívek közösen éneklik. Ebböl azonban még nem következik egyenesen az, hogy a szövegek megszólalója a T./1. személyü $m i$, a közösség legyen. Hiszen a zsoltárok többségében Dávid éneke és/vagy imája található meg, melyet E./1.-ben mond el.

Az ilyen jellegü szövegek jellemzője, hogy a zsoltárt magyarázó, bevezető strófákkal indít az ének, - Dávid miért, mikor, könyörög ekképpen - majd egy összegző strófa is található a végén, olykor applikatív mozzanattal, amely már a hívekre irányul: mi is így tegyünk, ahogyan Dávid. A zsoltárok esetében több ízben is előfordul azonban, hogy az applikatív mozzanatra, az ószövetségi helyzetet az ének elhangzásának idejével történő párhuzam megteremtésére úgy kerül sor, hogy a gyülekezet az adott zsoltárt már eleve T./1ben mondja, mintha Dávid is a népe nevében énekelné, s ennek nyomán a gyülekezet tagjai is a „nép,” a T./1. részeseként énekel.

A bibliai történetek és az ének elhangzásának jelene néhány apróbb változtatással, applikatív mozzanattal megtörténik például a Mikor a zsidó nemzet tartatnék Babilóniában...

\footnotetext{
307 Dolgozatunk szempontjából messzire vezető lenne kitérni arra, hogy érdekes módon az ilyen, feltehetően megrendelésre készült szövegekből a kolofonok, a referenciális részek kikopásának tárgyalásakor három olyan éneket is tudunk példaként hozni, amely a 71. zsoltár parafrázisa. A Nagybáncsai Mátyás nevére íródott, a Ládonyi Sára nevére íródott, és a Németi Ferenc nevére íródott ének is ezt a zsoltárt dolgozza át. Feltehetően ennek oka a zsoltár személyes hangvételében keresendő, amely miatt népszerủ lehetett.

${ }^{308}$ Eddig a szöveg: Debrecen, 1590, Bártfa 1593, Debrecen, 1602, Bártfa 1602-14, Kolozsvár 1602-15, Kolozsvár 1632, Kolozsvár 1697, Csonka antifonálé.

A szöveg folytatódik ezzel: ezerötszáz hatvanháromban. 1569 Debrecen, 1570 Debrecen, 1574 Komjáti, 1582 Detrekő.

Az 1579-es kiadásban szereplő szövegváltozat az általam ismert példányban csonkult, így nem tudjuk, volt-e évszám a végén.
} 
kezdetű énekben (RPHA 926). Az ének alapja Dániel könyve: 9,4-19. Az ének ismereteink szerint az 1574-es komjáti kiadásban jelent meg először, majd az 1582-es detrekőiben, az 1590-es debreceni, az 1593-as bártfai, az 1602-es debreceni, az 1602-14 közötti bártfai, végül az 1602-15 közötti kolozsvári (s ennek nyomán az unitárius gyülekezeti énekeskönyvekben) is.

Az ének első, bevezető strófája ismereti a bibliai történet kiindulópontját: a zsidóság babiloni fogsága alatt Dániel úgy könyörgött, ahogyan az le lesz írva a következő strófákban. A második versszakban kezdődik el Dániel könyörgése, az 1574-es komjáti és az 1582-es detrekői és az 1593-as bártfai kiadás alapján a következőképpen:

„,Neked könyörgök, mennybéli Isten, alázatossággal...”

Dániel könyörgése ezekben a kiadásokban aztán a nép múltbéli vétkeit, hibáit már T./1.-ben sorolja fel, de a könyörgés az Úrhoz, az Isten megszólítása az 1574-es és az 1582-es kiadásokban (az 1593-as bártfaiban ez változik már) végig E./1.-es személyü marad. A 10. versszak eleje például így hangzik az 1574-es és az 1582-es kiadásban:

„Mégis azt mondom, hogy pironkodás legyen mi orcánknak...”

Dániel mondja tehát, E./1.-ben, de a zsidó nép nevében. E két kiadás ezt következetesen viszi végig a versben, például a 25. strófában: „De hallgassad meg, örök Úristen én imádságomat...” vagy a 27. versszakban: „, Hajtsd le énhozzám, én uram, Isten, a te füleidet..."

Ehhez a T./1. nevében, a „rólunk” szóló, tehát a zsidóság helyzetét tárgyaló, de egyes szám első személyü könyörgésben explicit kifejeződik a nemzetért, az egész népért való aggodalom, az egész népért való könyörgés. A 17. versszakban például kimondva szerepel az, hogy Dániel a zsidó nemzetért könyörög: ${ }^{309}$

„Ím, mely kárt tönek Jeruzsálemnek, mint a zsidó népnek,/ soha nem volt így ég alatt dolga valamely nemzetnek,/ mely nagy szertelen veszedelme lön a zsidó nemzetnek."

${ }^{309}$ Az 1574-es komjáti és az 1582-es detrekői kiadásokban szerepel ez a változat. 
Az 1574-es és az 1582-es kiadásban szereplő szöveg beszédhelyzete tehát egyértelmü: aki ezt az éneket énekli, az Dániel hangján beszél a zsidó nép sanyargatásáról, s a zsidó népnek, s a zsidósággal együtt - a 26. strófa alapján, melyben a Messiásra hivatkozik, - a keresztényeknek kér kegyelmet. E két nyomtatványban a záró strófa teszi lehetővé, hogy az aktuális éneklő részese lehessen az általa énekelt kérésnek:

„Dicséret legyen a magasságban a mennyei Úrnak,/ ki építöje és nagy oltalma a mi városinknak,/ mert megkegyelmez ö jövendöre, a mi országunknak. ”310

Az 1590-es debreceni kiadástól kezdve azonban már megváltozik az alap beszédhelyzet is, mi több, a könyörgés témája is applikálódik - s nem csak az utolsó strófában. $^{311}$

Az első strófa minden variánsban ismerteti, hogy Dániel könyörgése az, amely úgy szól, ahogyan az ének maga. A második versszakban azonban Dániel már eleve többes számban szólítja meg az Istent: ${ }^{312}$ „Neked könyörgünk, mennybéli Isten, alázatos szívvel...”

A 10. versszakban is többes számúra változik a szöveg mindenütt: „Mégis azt mondjuk...."

A 25. és a 27. strófa, melyben Dániel ismét az Úristenhez való könyörgését, a hozzá fordulását hangsúlyozza, ismét többes szám első személyben, „mi”-ként szólal meg:

25. vsz.: „De hallgassad meg, örök Úristen, mi imádságinkat...”

27. vsz.: „Hajtsd le mihozzánk, Atyánk, Úristen, a te füleidet...”

A gyülekezet tehát ezekben a variánsokban többes szám első személyben, Dániellel együtt mondja nem csak a nép hibáit, a sanyargatást, hanem magát az Istenhez forduló könyörgést, kéréseket is. Mi több, az 1582-es kiadás után már nem csak a közösségi könyörgés valósul meg, hanem az az applikatív mozzanat is, amellyel a zsidóság babiloni

\footnotetext{
${ }^{310}$ Egyedül az unitárius szövegváltozatok különböznek ettöl: ott oltalmat az Isten népeinek kérnek a város helyett, illetve az országnak megkegyelmező Isten helyett a híveknek való megkegyelmezés áll a szövegben. Az idézet a többi helyen azonos: 1574 Komjáti; 1582 Detrekő; 1590 Debrecen; 1593 Bártfa; 1602 Debrecen; 1602 14 Bártfa.

311 A következőkben leírt példák egyaránt érvényesek az 1582 után megjelent összes nyomtatvány variánsára, hacsak nem emeljük ki az eltérést. Így a következők az 1590-es debreceni, az 1593-as bártfai, az 1602-es debreceni, az 1602-14 közötti bártfai, az 1602-15 közötti kolozsvári, az 1632-es és az 1697-es kolozsvári kiadások variánsainak egyaránt jellemzői lesznek.

${ }^{312}$ Egyedüli kivétel itt az 1593-as bártfai kiadás, amelyben ugyanúgy E./1. van, mint az 1574-es komjáti és az 1582-es detrekői kiadásokban. Az 1593-as bártfai kiadás a későbbiekben viszont már nem az 1574-es és az 1582-es kiadásokat követi, hanem a többivel egyezik meg.
} 
fogsága konkrét párhuzamba állítódik a keresztény - pogány, illetve a magyar nép - pogány nép szembeállításával. Ezáltal nem csak az utolsó strófa teszi lehetővé azt, hogy az éneklő személy azonosuljon az ének szövegében megjelenő sanyargatottal, hanem az azonosság, a sorspárhuzam már korábban, a 17. strófában megteremtődik azáltal, hogy itt Jeruzsálem és a zsidó nép helyett a kereszténység és a magyar nép jelenik meg: ${ }^{313}$

„Ím, mely kárt tönek keresztyénségben, mind a magyar népnek,/ soha nem volt így ég alatt dolga valamely nemzetnek,/ mely nagy szertelen veszedelme lön a magyar nemzetnek."

Az 1590-es kiadástól kezdve tehát Dániel könyörgése is többes szám első személyü, illetve a zsidóság babiloni helyzetének ismertetése mellett 1590-től a szöveg részévé válik a magyar nemzet párhuzama is. Bár ezzel a szöveg eltávolodik a bibliai helytől, melyet énekbe foglal, ám a gyülekezethez, a gyülekezetben való énekléshez közelebb kerül, hiszen az éneklő ezáltal már nem Dániel „szócsöve,” nem Dániel imájának a közvetítője, hanem Dániellel együtt imádkozik az Istenhez. Az applikatív mozzanat pedig lehetővé teszi azt, hogy az imádkozók kérése együttesen válhasson lehetővé, hiszen a gondok forrása is hasonló - t. i. a sanyargató ellenség.

Noha a szöveg eltávolodik a forrásától, annak gyülekezetiesedését, a közösségi éneklést ezek a szövegváltozások mindenképp elősegítik.

Számos teljesen személyes, egyes szám első személyű szöveget ismerünk, amelyeknek a funkciója a személyes Istenhez szólás. Sok ilyen szöveg megtalálható a gyülekezeti énekeskönyvekben is. Még ezeknek a személyes hangvételü szövegeknek a teljes többes szám első személyüre váltására is tettek kísérletet az unitáriusok. Valószínü, hogy nem nagy sikerrel, ugyanis olyan énekeket raktak át egyes számból többesbe, amelyek már a protestáns gyülekezeti énekeskönyvek legelső kiadásaiban is szerepeltek, tehát régóta ismertek voltak. Feltehetően ezért sem állandósulhatott az a szövegváltozat, amely így jött létre. Minden esetre meg kell jegyeznünk, hogy a példa nem csupán azt mutatja be, miként változik következetlenül az „én” elbeszélő „mi”-vé, hanem összesen kettő olyan énekvariánssal is szembesít bennünket, ahol ez a váltás az egész éneken keresztülvonul.

\footnotetext{
${ }^{313}$ Itt persze gondolhatnánk azt is, hogy a zsidóság elnyomásának és Jeruzsálem megszállásának a képét az 1590-es évektől azért veszik ki, hogy az ismert krisztianizáló tendencia érvényesüljön, s a keresztény voltukat tüntetően hangoztassák. Itt azonban nem erről van szó, hiszen Dánielt, a zsidóságot, Izraelt és Mózest, illetve Babilont és Dárius királyt nem szedik ki az énekből a későbbi variánsok sem. Ezért gondolhatunk inkább arra, hogy a közösségteremtő, az applikálhatóság érdekében történő párhuzamteremtés az, amely ezt a változást okozhatja.
} 
Ilyen, a nyomtatott unitárius hagyományban végig megmaradó többes számra váltással találkozhatunk az Úristen, irgalmazz nekem... kezdetü ének esetében (RPHA 1436). A szöveg eredeti, személyes hangvétele érthető: az Úrtól a bünök megbocsátását, a helyes életre vezérlést kéri az egyes szám első személyü beszélő. Így, ebben a formában találjuk meg a szöveget a következő kiadásokban: 1560 Óvár; 1569 Debrecen; 1570 Debrecen; 1574 Komjáti; 1579 Debrecen (hiányzik az ének az általam ismert forrásból); 1582 Detrekő; 1590 Debrecen; 1593 Bártfa.

Az unitárius gyülekezeti énekeskönyvek, illetve a Csonka antifonálé és az 1660-as unitárius temetési énekeskönyv azonban végig, következetesen többes szám első személyben hozza az éneket. ${ }^{314}$

Ugyanez a következetes T./1. használat figyelhető meg a Nagy hálaadással magasztallak téged... kezdetü éneknek az 1602-15 közötti kolozsvári unitárius gyülekezeti énekeskönyvben, illetve a Csonka antifonáléban található változatánál, bár érdekes módon e két forrásban is megmarad az első strófa egyes szám első személyü alakja, mi több, több olyan versszak van az említett két unitárius forrásban is, amely nem következetes, s visszavált egyes szám első személyre. Feltehető, hogy a régóta ismert éneket az első gyülekezeti énekeskönyv szerkesztése során igyekeztek „közösségivé” tenni azáltal, hogy átteszik a beszélő személyét „,mi”-re, ám ezt nem sikerült rögzíteni, hiszen az 1632-es és az 1697-es unitárius gyülekezeti énekeskönyv már a korábbi protestáns források változatait hozza, E./1. személyü beszélővel.

Az ének a következőképp változik:

\section{RPHA 1031 Nagy hálaadással magasztallak téged, én Istenem - Ps 144=145.}

Szerezte Németi Ferenc, nem dedikált. Idegen minta: Ps 144=145.Akrosztichonja: NOIM OPVS FRANCISCI NEMETI. Nincs kolofon. Keletkezési idő nem később, mint 1565. Modern kiadása: RMKT-7-163.

a16(6,4,6), a16(6,4,6), a16(6,4,6)

\section{Kéziratos forrása:}

Csonka antifonálé, 1607-1632, unitárius (S 143) p. $65^{\mathrm{r}}$.a Sequuntur részben, az első abcrendben. Cím: Psalmus 145.

\footnotetext{
${ }^{314}$ A szöveget összevetve a Luther-féle Biblia változatával azt találjuk, hogy a zsoltár ott is egyes szám első személyủ beszélővel szerepel. A Luther-féle német szövegek összevetéséhez a következő kiadást használjuk a dolgozatban: Die Bibel oder die ganze Heilige Schrift des Alten und Neuen Testaments (Nach der deutschen Übersetzung Martin Luthers), Württembergische Bibelanstalt Stuttgart, 1968.
} 


\section{Nyomtatott kiadásai:}

Várad, 1566, (RMNy 222, [fakszimile kiadás]) p. 103, cím: Psalmus 144. Örök Atya Isten men.

Debrecen, 1569, (RMNy 264, [fakszimile kiadás]) p. 73, a zsoltároknál, cím: Psalmus 144.

Debrecen, 1570, (RMNy 276) p. 82, a zsoltároknál, cím: Psalmus 144.

Komjáti, 1574, (RMNy 353/2, [fakszimile kiadás]) p. $90^{\mathrm{v}}$ a szentegyházba való isteni dicséretek résznél, a zsoltároknál, cím: 145. Psalmus. Exaltabo te Deus meus Rex etc. Nótája: Örök Atyaisten, mennynek, földnek etc.

Debrecen, 1579, (RMNy 429) p. 72, a zsoltároknál, cím: 144. Psalmus.

Detrekő, 1582, (RMNy 513, [fakszimile kiadás]) p. 129va a közönséges isteni dicséreteknél, a zsoltárrészben, cím: 145. psalmus. Exaltabo te Deus meus Rex etc. Nótája: Örök Atyaisten, mennynek, földnek etc.

Debrecen, 1590, (RMNy 640) p. 81, 144. Psalmus címmel a zsoltárok között.

Bártfa, 1593, (RMNy 713) p. 223. A Szentháromság nap után való dicséreteknél, cím: Psalmus 144.

Debrecen, 1602, (RMNy 886/1) p. 71v, a zsoltároknál, cím: 145. Psalmus. Nóta: Ilyen fogadást tön $\ldots$

Bártfa, 1602-1614, (RMNy 965) p. 301, a Hálaadó dicséreteknél, cím: Psalmus 145.

Kolozsvár, 1602-1615, (RMNy 983) p. 416, a zsoltárrészben, cím: Psalmus 145.

Kolozsvár, 1632, (RMNy 1541) p. 496, a zsoltár és egyéb énekrészben, cím: Psalmus 145. Nóta: Ilyen fogadást tőn a Szent Dávid...

Kolozsvár, 1697, (RMK I 1503) p. 337, a zsoltár és egyéb énekrészben, cím: Psalmus 145. Nóta: Ilyen fogadást tön a Szent Dávid...

Nagy hálaadással magasztallak téged, én Istenem,

kegyelmességedröl valamikor én megemlékezem,

örökkön-örökké minden napon téged kell ${ }^{315}$ dicsérnem.

Oly nagy tiszteletre, dicséretre tölünk ${ }^{316}$ méltó volnál, ha hozzád illendö tisztességet minálunk $k^{317}$ találnál,

\footnotetext{
315 kér: 1570 Debrecen.

316 tőlem: 1632 Kolozsvár, 1697 Kolozsvár, 1566 Várad, 1569 Debrecen, 1570 Debrecen, 1574 Komjáti, 1579 Debrecen, 1582 Detrekő, 1590 Debrecen, 1593 Bártfa, 1602 Debrecen, 1602-14 Bártfa.
} 
de nincsen mit adnunk ${ }^{318}$ többet Uram, a hálaadásnál. ${ }^{319}$

Időröl-időre mi hirdetjük ${ }^{320}$ hatalmasságodat,

az üdvözitésben, teremtésben való jóvoltodat,

mert nagy szerelmedböl nem kíméled tölünk ${ }^{321}$ szent fiadat.

Megjelented nekünk ${ }^{322}$ régtöl ${ }^{323}$ fogva való titkaidat,

a te vigasztaló, bátoritó örömmondásodat,

te szent lelked által onnét értjük ${ }^{324}$ jó akaratodat.

Örök dicsőségre, tisztességre, hogy minket ${ }^{325}$ hivatál,

a mi büneinknek ${ }^{326}$ nagyságából mikor kitisztitál,

akkoron mutattad, hogy magadnak minket ${ }^{327}$ választottál.

Pecsétes gyürüddel, szent lelkeddel magadnak foglalál,

erös reménységgel, igaz hittel szépen felruházál,

örökös társává a ${ }^{328}$ Krisztusnak te minket ${ }^{329}$ választál.

Vala Uram nekünk ${ }^{330}$ teelötted nagy sok adósságunk, ${ }^{331}$

kiért te szent fiad Jézus Krisztus lön értünk váltságunk, ${ }^{332}$

317 énnálam: 1632 Kolozsvár, 1697 Kolozsvár, 1566 Várad, 1569 Debrecen, 1570 Debrecen, 1574 Komjáti, 1579 Debrecen, 1582 Detrekö, 1590 Debrecen, 1593 Bártfa, 1602 Debrecen, 1602-14 Bártfa.

318 adnom: 1632 Kolozsvár, 1697 Kolozsvár, 1566 Várad, 1569 Debrecen, 1570 Debrecen, 1574 Komjáti, 1579

Debrecen, 1582 Detrekő, 1590 Debrecen, 1593 Bártfa, 1602 Debrecen, 1602-14 Bártfa.

319 hálaadásnak: Csonka antifonálé.

320 én hirdetem: 1632 Kolozsvár, 1697 Kolozsvár, 1566 Várad, 1569 Debrecen, 1570 Debrecen, 1574 Komjáti, 1579 Debrecen, 1582 Detrekő, 1590 Debrecen, 1593 Bártfa, 1602 Debrecen, 1602-14 Bártfa.

321 tőlem: 1632 Kolozsvár, 1697 Kolozsvár, 1566 Várad, 1569 Debrecen, 1570 Debrecen, 1574 Komjáti, 1579

Debrecen, 1582 Detrekő, 1590 Debrecen, 1593 Bártfa, 1602 Debrecen, 1602-14 Bártfa.

322 nekem: 1632 Kolozsvár, 1697 Kolozsvár, 1566 Várad, 1569 Debrecen, 1570 Debrecen, 1574 Komjáti, 1579

Debrecen, 1582 Detrekő, 1590 Debrecen, 1593 Bártfa, 1602 Debrecen, 1602-14 Bártfa.

323 örörktöl: 1566 Várad, 1569 Debrecen, 1570 Debrecen, 1574 Komjáti, 1579 Debrecen, 1582 Detrekő, 1590

Debrecen, 1593 Bártfa, 1602 Debrecen, 1602-14 Bártfa.

324 értem: 1632 Kolozsvár, 1697 Kolozsvár, 1566 Várad, 1569 Debrecen, 1570 Debrecen, 1574 Komjáti, 1579

Debrecen, 1582 Detrekő, 1590 Debrecen, 1593 Bártfa, 1602 Debrecen, 1602-14 Bártfa.

${ }^{325}$ engem: 1632 Kolozsvár, 1697 Kolozsvár, 1569 Debrecen, 1570 Debrecen, 1574 Komjáti, 1579 Debrecen, 1582 Detrekő, 1590 Debrecen, 1593 Bártfa, 1602 Debrecen, 1602-14 Bártfa.

${ }^{326}$ az én büneimnek: 1632 Kolozsvár, 1697 Kolozsvár, 1566 Várad, 1569 Debrecen, 1570 Debrecen, 1574

Komjáti, 1579 Debrecen, 1582 Detrekő, 1590 Debrecen, 1593 Bártfa, 1602 Debrecen, 1602-14 Bártfa.

327 engem: 1632 Kolozsvár, 1697 Kolozsvár, 1566 Várad, 1569 Debrecen, 1570 Debrecen, 1574 Komjáti, 1579

Debrecen, 1579 Debrecen, 1582 Detrekő, 1590 Debrecen, 1593 Bártfa, 1602 Debrecen, $1602-14$ Bártfa.

328 mert: 1570 Debrecen, 1574 Komjáti, 1579 Debrecen, 1582 Detrekő, 1590 Debrecen, 1593 Bártfa, 1602 Debrecen, 1602-14 Bártfa.

${ }^{329}$ engemet: 1632 Kolozsvár, 1697 Kolozsvár, 1566 Várad, 1569 Debrecen, 1570 Debrecen, 1574 Komjáti, 1579

Debrecen, 1582 Detrekő, 1590 Debrecen, 1593 Bártfa, 1602 Debrecen, 1602-14 Bártfa.

${ }^{330}$ nekem: 1632 Kolozsvár, 1697 Kolozsvár, 1566 Várad, 1570 Debrecen, 1574 Komjáti, 1579 Debrecen, 1582

Detrekő, 1590 Debrecen, 1593 Bártfa, 1602 Debrecen, 1602-14 Bártfa.

331 adósságom: 1632 Kolozsvár, 1697 Kolozsvár, 1566 Várad, 1569 Debrecen, 1570 Debrecen, 1574 Komjáti, 1579 Debrecen, 1582 Detrekő, 1590 Debrecen, 1593 Bártfa, 1602 Debrecen, 1602-14 Bártfa.

332 értem váltságom: 1632 Kolozsvár, 1697 Kolozsvár, 1566 Várad, 1569 Debrecen, 1570 Debrecen, 1574

Komjáti, 1579 Debrecen, 1582 Detrekő, 1590 Debrecen, 1593 Bártfa, 1602 Debrecen, 1602-14 Bártfa. 
azért vagyon mostan mi szívünkben ${ }^{333}$ ilyen bátorságunk. ${ }^{334}$

Sokszor emlékeztünk ${ }^{335}$ jóvoltodról mi ${ }^{336}$ nagy szükségünkben, ${ }^{337}$

kit mégis köszönni mi nem tudunk életünkben, ${ }^{338}$

azért kiált hozzád a mi lelkünk ${ }^{339}$ ö nagy örömében.

Felette irgalmas és ${ }^{340}$ kegyelmes áldott ${ }^{341}$ Istenünk $^{342}$ vagy,

a megbüntetésben, ${ }^{343}$ vereségre, haragra késő vagy,

hosszú ideiglen szenvedhetö irgalmas Isten vagy.

Reánk ${ }^{344}$ szíve szerint fiaira ${ }^{345}$ Atyánk $^{346}$ nem haragszik,

erötlenségünkért ${ }^{347}$ mikor ver is kedve ellen esik,

ha sanyarú kézzel nyúl is hozzánk ${ }^{348}$, mégis jónkra ${ }^{349}$ esik.

Az ö nagy jóvoltát az Úristen nem csak ránk ${ }^{350}$ terjeszté,

jókra, gonoszokra Napot, Holdat ö kiszélesité,

333 én szívemben: 1632 Kolozsvár, 1697 Kolozsvár, 1566 Várad, 1569 Debrecen, 1570 Debrecen, 1574 Komjáti, 1579 Debrecen, 1582 Detrekő, 1590 Debrecen, 1593 Bártfa, 1602 Debrecen, 1602-14 Bártfa.

${ }^{334}$ bátorságom: 1632 Kolozsvár, 1697 Kolozsvár, 1566 Várad, 1569 Debrecen, 1570 Debrecen, 1574 Komjáti, 1579 Debrecen, 1582 Detrekő, 1590 Debrecen, 1593 Bártfa, 1602 Debrecen, 1602-14 Bártfa.

335 emlékeztem: 1632 Kolozsvár, 1697 Kolozsvár, 1566 Várad, 1569 Debrecen, 1570 Debrecen, 1574 Komjáti, 1579 Debrecen, 1582 Detrekő, 1590 Debrecen, 1593 Bártfa, 1602 Debrecen, 1602-14 Bártfa.

336 én: 1632 Kolozsvár, 1697 Kolozsvár, 1566 Várad, 1569 Debrecen, 1570 Debrecen, 1574 Komjáti, 1579 Debrecen, 1582 Detrekö, 1590 Debrecen, 1593 Bártfa, 1602 Debrecen, 1602-14 Bártfa.

337 szükségemben: 1632 Kolozsvár, 1697 Kolozsvár, 1566 Várad, 1569 Debrecen, 1570 Debrecen, 1574 Komjáti, 1579 Debrecen, 1582 Detrekő, 1590 Debrecen, 1593 Bártfa, 1602 Debrecen, 1602-14 Bártfa.

338 én nem tudok teljes életemben: 1632 Kolozsvár, 1697 Kolozsvár, 1566 Várad, 1569 Debrecen, 1474 Komjáti, 1570 Debrecen, 1579 Debrecen, 1582 Detrekő, 1590 Debrecen, 1593 Bártfa, 1602 Debrecen, 1602-14 Bártfa.

339 az én lelkem: 1632 Kolozsvár, 1697 Kolozsvár, 1566 Várad, 1569 Debrecen, 1570 Debrecen, 1579 Debrecen, 1582 Detrekő, 1593 Bártfa, 1602 Debrecen, 1602-14 Bártfa.

340 mert: 1569 Debrecen, 1570 Debrecen, 1574 Komjáti, 1579 Debrecen, 1582 Detrekő, 1590 Debrecen, 1593

Bártfa, 1602 Debrecen, 1602-14 Bártfa.

${ }^{341}$ nincs áldott: 1569 Debrecen,.

kegyes: 1570 Debrecen, 1574 Komjáti, 1579 Debrecen, 1582 Detrekő, 1590 Debrecen, 1593 Bártfa, 1602 Debrecen, 1602-14 Bártfa.

342 Istenem: 1632 Kolozsvár, 1697 Kolozsvár, 1566 Várad, 1569 Debrecen, 1570 Debrecen, 1574 Komjáti, 1579

Debrecen, 1582 Detrekő, 1590 Debrecen, 1593 Bártfa, 1602 Debrecen, 1602-14 Bártfa.

${ }^{343}$ megbüntetésre: 1566 Várad, 1569 Debrecen, 1570 Debrecen, 1574 Komjáti, 1579 Debrecen, 1582 Detrekő, 1590 Debrecen, 1593 Bártfa, 1602 Debrecen, 1602-14 Bártfa.

344 reám: 1632 Kolozsvár, 1697 Kolozsvár, 1566 Várad, 1569 Debrecen, 1570 Debrecen, 1574 Komjáti, 1579

Debrecen, 1582 Detrekő, 1590 Debrecen, 1593 Bártfa, 1602 Debrecen, 1602-14 Bártfa.

345 mint fiára: 1632 Kolozsvár, 1697 Kolozsvár, 1566 Várad, 1569 Debrecen, 1570 Debrecen, 1574 Komjáti, 1579 Debrecen, 1582 Detrekő, 1590 Debrecen, 1593 Bártfa, 1602 Debrecen, 1602-14 Bártfa.

346 atyám: 1632 Kolozsvár, 1697 Kolozsvár, 1566 Várad, 1569 Debrecen, 1570 Debrecen, 1574 Komjáti, 1579

Debrecen, 1582 Detrekő, 1590 Debrecen, 1593 Bártfa, 1602 Debrecen, 1602-14 Bártfa.

347 erőtlenségemért: 1632 Kolozsvár, 1697 Kolozsvár, 1566 Várad, 1569 Debrecen, 1570 Debrecen, 1574 Komjáti, 1579 Debrecen, 1582 Detrekő, 1590 Debrecen, 1593 Bártfa, 1602 Debrecen, 1602-14 Bártfa.

348 hozzám: 1632 Kolozsvár, 1697 Kolozsvár, 1566 Várad, 1569 Debrecen, 1570 Debrecen, 1574 Komjáti, 1579

Debrecen, 1582 Detrekő, 1590 Debrecen, 1593 Bártfa, 1602 Debrecen, 1602-14 Bártfa.

349 jómra: 1632 Kolozsvár, 1697 Kolozsvár, 1566 Várad, 1569 Debrecen, 1570 Debrecen, 1574 Komjáti, 1579

Debrecen, 1582 Detrekő, 1590 Debrecen, 1593 Bártfa, 1602 Debrecen, 1602-14 Bártfa.

350 rám: 1632 Kolozsvár, 1697 Kolozsvár, 1566 Várad, 1569 Debrecen, 1570 Debrecen, 1574 Komjáti, 1579

Debrecen, 1582 Detrekő, 1590 Debrecen, 1593 Bártfa, 1602 Debrecen, 1602-14 Bártfa. 
földet és a mennyet életünkre minékünk teremté.

Nincs nagyobb jótéted soha velünk ${ }^{351}$ irgalmasságodnál, nagy kegyelmességed feljebb áradt te igazságodnál, szent Fiad érdeme nagyobb, Uram, mi ${ }^{352}{ }^{353}$ álnokságinknál. ${ }^{354}$

Csuda jóvoltodból megtámasztod, akik elesnének, kegyelmességedböl felemeled, kik immár elestek, erötlenségükböl el nem üzöd, akik vétkeztenek. ${ }^{355}$

Ím, minden állatnak ${ }^{356}$ sok szemei csak tereád néznek, ö nagy szükségekben, ínségekben ${ }^{357}$ tégedet keresnek, teremtö, éltetö Istenüknek ${ }^{358}$ tégedet jelentnek.

Segélled étellel és itallal minden szükségükben, a holló fiaknak eledelt adsz az önnön fészkekben, mikoron anyjuktól elhagyatnak ö nagy éhségükben.

Csak megvonszod Uram a szükségben erös hatalmadat, ismét ha akarod a böségre kinyitod karodat, kegyelmességedböl ${ }^{359}$ igy mutatod hozzánk jóvoltodat.

Igen igazmondó vagy Úristen minden dolgaidban, kit egyszer megmondassz, soha senki nem ér téged másban, ez nagy vigassága mi lelkünknek ${ }^{360}$ minden bánatjában.

Nagy közel vagyon ${ }^{361}$ hozzám én Istenem, mint atya fiaihoz, ${ }^{362}$ az én kiáltásom felinditson a meghallgatásra, ${ }^{363}$

351 velem: 1632 Kolozsvár, 1697 Kolozsvár, 1566 Várad, 1569 Debrecen, 1570 Debrecen, 1574 Komjáti, 1579 Debrecen, 1582 Detrekő, 1590 Debrecen, 1593 Bártfa, 1602 Debrecen, 1602-14 Bártfa.

352 én: 1632 Kolozsvár, 1697 Kolozsvár, 1566 Várad, 1569 Debrecen, 1570 Debrecen, 1574 Komjáti, 1579 Debrecen, 1582 Detrekő, 1590 Debrecen, 1593 Bártfa, 1602 Debrecen, 1602-14 Bártfa.

${ }^{353}$ szórendcsere: én uram: 1569 Debrecen, 1570 Debrecen.

354 álnokságomnál: 1632 Kolozsvár, 1697 Kolozsvár, 1566 Várad, 1569 Debrecen, 1570 Debrecen, 1574 Komjáti, 1579 Debrecen, 1582 Detrekő, 1590 Debrecen, 1593 Bártfa, 1602 Debrecen, 1602-14 Bártfa.

355 elvesztenek: 1632 Kolozsvár.

356 állatok: 1579 Debrecen.

357 éhségekben: 1566 Várad, 1569 Debrecen, 1570 Debrecen, 1574 Komjáti, 1579 Debrecen, 1582 Detrekő, 1590 Debrecen, 1593 Bártfa, 1602 Debrecen, 1602-14 Bártfa.

${ }^{358}$ Istennek: Csonka antifonálé.

359 kegyelmességedet: 1566 Várad, 1569 Debrecen, 1570 Debrecen, 1574 Komjáti, 1579 Debrecen, 1582 Detrekő, 1590 Debrecen, 1593 Bártfa, 1602 Debrecen, 1602-14 Bártfa.

360 én lelkemnek: 1632 Kolozsvár, 1697 Kolozsvár, 1566 Várad, 1569 Debrecen, 1570 Debrecen, 1574 Komjáti, 1579 Debrecen, 1582 Detrekő, 1590 Debrecen, 1593 Bártfa, 1602 Debrecen, 1602-14 Bártfa.

361 vagy: 1566 Várad, 1569 Debrecen, 1570 Debrecen 1574 Komjáti, 1579 Debrecen, 1582 Detrekő, 1590 Debrecen, 1593 Bártfa, 1602 Debrecen, 1602-14 Bártfa.

362 fiához: 1632 Kolozsvár, 1697 Kolozsvár, 1566 Várad, 1569 Debrecen, 1570 Debrecen, 1574 Komjáti, 1579 Debrecen, 1582 Detrekő, 1590 Debrecen, 1593 Bártfa, 1602 Debrecen, 1602-14 Bártfa. 
mert tiszta lélekböl megyek hozzád, mint édes Atyámhoz.

Én akaratomat cselekedted jó akaratodból, igaz törvényt tettél énfelölem Uram mindenekböl, sokszor levetettél meg felvettél kegyelmességedböl.

Megőrizted Uram mindazokat, kik téged szerettek, ${ }^{364}$ hála legyen neked, el nem vetted, ${ }^{365}$ kik benned biztanak, ${ }^{366}$ kiért mindörökké minden népek tégedet dicsérnek ${ }^{367}$.

Erős oltalma vagy és gyámola a szegény árváknak, a nyomorultaknak hivattatol egyedül atyjuknak, légy megszabaditónk Uram most is minekünk foglyoknak. ${ }^{368}$

Tenéked, ${ }^{369}$ Úristen, mindezekről adok nagy hálákat, kérlek, hogy végiglen mind ${ }^{370371}$ megtartsad ebben a fiakat, kik téged tisztelnek, mint atyjukat, örökkön örökké. ${ }^{372}$

Ilyen hálaadást Dávid király tön a zsoltárkönyvben, ö dicséretének a száznegyvenötödik ${ }^{373}$ részében, hogy hálákat adjunk az Istennek mindenkor szívünkben.

A klasszikus kolofonstrófák kikopása, s helyükre az éneket összegző, a „mi is dicsérjük"-típusú záró és/vagy hivatkozó strófák bekerülése azt jelzi, hogy a gyülekezeti, a közösségi igényhez való alkalmazkodás szándékolt cél volt a gyülekezeti énekgyüjtemények összeállításakor.

363 meghallgatáshoz: 1632 Kolozsvár, 1697 Kolozsvár, 1566 Várad, 1569 Debrecen, 1570 Debrecen, 1574 Komjáti, 1579 Debrecen, 1582 Detrekő, 1590 Debrecen, 1593 Bártfa, 1602 Debrecen, 1602-14 Bártfa.

${ }^{364}$ szeretnek: 1566 Várad, 1569 Debrecen, 1570 Debrecen, 1574 Komjáti, 1579 Debrecen, 1582 Detrekő, 1590 Debrecen, 1593 Bártfa, 1602-14 Bártfa.

365 vesztek: 1566 Várad, 1569 Debrecen, 1570 Debrecen, 1574 Komjáti, 1579 Debrecen, 1582 Detrekő, 1590 Debrecen, 1593 Bártfa, 1602 Debrecen, 1602-14 Bártfa.

366 hittenek: 1566 Várad, 1569 Debrecen, 1570 Debrecen, 1574 Komjáti, 1579 Debrecen, 1582 Detrekő, 1590 Debrecen, 1593 Bártfa, 1602 Debrecen, 1602-14 Bártfa.

${ }^{367}$ szentek téged dicsértenek: 1566 Várad, 1569 Debrecen, 1570 Debrecen, 1574 Komjáti, 1579 Debrecen, 1582 Detrekő, 1590 Debrecen, 1593 Bártfa, 1602 Debrecen, 1602-14 Bártfa.

368 solgyoknak [szerintem az álfacsimile ront]: 1569 Debrecen.

369 ez a strófa hiányzik: 1582 Detrekő.

370 nincs mind: 1579 Debrecen.

mindvégiglen: 1590 Debrecen, 1602 Debrecen.

371 mindvégiglen mind: 1593 Bártfa.

372 mindörökké, mint édes atyjukat: 1566 Várad, 1569 Debrecen, 1570 Debrecen, 1574 Komjáti, 1579 Debrecen, 1590 Debrecen, 1593 Bártfa, 1602 Debrecen, 1602-14 Bártfa.

373 nincs a, száznegyvennegyedik: 1566 Várad, 1569 Debrecen, 1570 Debrecen, 1579 Debrecen, 1590 Debrecen, 1593 Bártfa, 1602-14 Bártfa.

nincs a, száz és negyven ötödik: 1582 Detrekő, 1602 Debrecen. 
Az egyes énekgyűjteményekben megfigyelhető, hogy némely szöveg igyekszik a gyülekezetiesedést azzal is erősíteni, hogy az egyes szám első személyü beszélő helyett többes szám első személyt használ. Mivel a korai gyüjtemények protestáns gyülekezeti énekei feltehetően ismertek voltak, emlékezetből énekelték azokat, így az unitáriusoknak az a próbálkozásuk, hogy az énekeket teljesen a közösségi éneklés T./1.-jébe helyezzék át, nem valósulhatott meg töretlenül.

\section{II. 3. Az akrosztichonok használata és szerepe a gyülekezeti énekekben}

A versek akrosztichonja feltehetően több célt szolgálhatott. Ahogyan azt Pap Balázs összefoglalja, ${ }^{374}$ az akrosztichon egyrészt a szöveg szerzőjéhez vagy a megrendelőjéhez füződő kapcsolatát fejezi ki a leggyakrabban. Az akorsztichon másrészt „a szöveg integritását hivatott szavatolni," ${ }^{375}$ azaz az akrosztichon segíti egyben tartani a szöveget. Amennyiben egy-egy strófa a másolások során elvész, az akrosztichon lehetővé teszi a csonkaság felismerését. Harmadik fontos funkcióként az akrosztichon mnemotechnikai jelentőségét szokás megjelölni, hiszen az akrosztichon ismerete segíti - mediális környezettől függően - a másolót, a nyomdászt, vagy az énekest a szöveg strófáinak egymás utáni felidézésében.

A gyülekezeti énekeskönyvekben, a kéziratos másolatokban több olyan E./1. személyü ének is fennmaradt, amelyek minden bizonnyal megrendelésre készültek, s az ajánlás található az akrosztichonban. (Ilyenek például a Dóci Ilona és Dóci Zsuzsanna nevére írott énekek, vagy a Németi Ferenc nevére írott ének.) Ezek a személyes fohászt, panaszt vagy kérést megfogalmazó énekek valószínüleg a megrendelők/támogatók nevének akrosztichonba foglalásával is erősítik a személyes vallásgyakorlatot. Az előzőekben már volt arról szó, hogy ezek a személyes énekek is ismertté válnak, feltehetően énekelni, másolni kezdik őket, így elterjednek, szövegeikben variálódnak.

Logikusnak tarthatnánk, hogy az akrosztichon miatt az ezzel rendelkező szövegek, így például az ilyen, a szerző nevét vagy az ajánlást tartalmazó gyülekezeti énekek kevéssé variálódjanak, legalábbis ami a strófák egymásutániságát illeti. A gyülekezet által közösen, vagy éppen otthon magánosan énekelt szövegek esetében kiválóan alkalmazható lenne az akrosztichon mint mnemotechnikai eszköz, ezért is következtethetnénk arra, hogy a

\footnotetext{
${ }^{374}$ PAP Balázs, i.m., Az akrosztichonokról c. fejezet, (131-49), főként 132-33.

${ }^{375}$ PAP, i.m., 132.
} 
gyülekezeti énekek közé bekerülő akrosztichonos verses szövegek nem változnak meg nagyon. Ez azonban érdekes módon nem így van. Mi több, az akrosztichonnal rendelkező gyülekezeti énekek többsége már az első ismert forrásában sem helyes, világos, érthető akrosztichonnal szerepel. Kivételek természetesen akadnak, de nagy általánosságban elmondható, hogy a nyomtatott és kéziratos gyülekezeti énekgyüjtemények többségében rossz akrosztichonnal szerepel az akrosztichonnal egykor rendelkező énekek döntő többsége. Ezek alapján talán mondhatjuk, hogy a gyülekezeti éneklésben az akrosztichon feltehetően nem szolgált olyan nagy mnemotechnikai szerepet, mint azt a históriás énekek kapcsán gondoljuk. Ha rendkívül lényeges lett volna, a gondos szerkesztők nyilvánvalóan igyekeztek volna „,visszahozni,” javítani a szövegek akrosztichonjait, de nem tették meg.

A Magas mennyben lakó Isten... kezdetű ének (RPHA 847) akrosztichonja az RPHA szerint MMIKHEEL KATEI. Az ének korai kéziratos forrásai az Alciatus-toldalék (S 5, 1596 körül) és a Lipcsei-kódex (S 32/1, 1615). Nyomtatott forrása a korból csupán az 1602-15 közötti unitárius énekeskönyv. Az Alciatus-toldalék variánsát sajnos nem állt módunkban tanulmányozni, de a Dézsi közlésében megjelent Lipcsei-kódexbeli változatot ${ }^{376}$ és az unitárius énekeskönyv variánsát összevetettük. Az RPHA az Alciatus-toldalék akrosztichonját idézi be, a Lipcsei-kódexé a következő: MMIKHEEL KETEIET. Az unitárius nyomtatványban a következőképp szerepel a Kátai (Káthay) Mihály nevére írott szöveg akrosztichonja: MMIKHEEL KETAIET. Az összes rendelkezésünkre álló forrásra jellemző, hogy a „Mikhael” két M-mel van írva. Valóban találkozunk olyan akrosztichonnal, amelyben egy-egy betű strófakezdő ismétlése bővítési lehetőséget teremt, erre Vadai István Tinódi pótlásos megoldásain keresztül mutat rá. ${ }^{377}$ Mégis, a Tinódi pótlásaitól messzi áll az, ha mindjárt az első strófa után, egy viszonylag rövid énekben következik be pótlás. Nem zárhatjuk ki, hogy egy ideálisan elképzelt szerzői variánsnak a második strófa nem volt része. A 6. strófában a Lipcsei-kódex és az unitárius énekeskönyv akrosztichont ront: a Mikhael helyett Mikheel olvasható, amely feltehetően egy apró cserével orvosolható: az $E$ világnak gyönyörüsége... kezdősor helyett $A$ világnak gyönyörüsége... állhatott. Az általunk vizsgált források a Kátai név után még hoznak két strófát, s ez valószínűleg utólagos hozzátoldás eredménye, de a legutolsó strófa mindenképp. Az utolsó előtti, Élsz most mennyben, ó, szent Isten... kezdetủ strófa azt mutatja, hogy az akrosztichonban megjelölt személyé az ének, míg a záró versszak, amely doxológiát tartalmaz, semmiféle viszonyban nem áll az

\footnotetext{
${ }^{376}$ Kiadja DÉZSI Lajos, ItK, 1916, 329.

${ }^{377}$ VADAI István, 1554: Megjelenik Tinódi Cronicája, A tudósitó ének müfaja = A magyar irodalom történetei, $A$ kezdetektöl 1800-ig, Bp., Gondolat, 2008, 280-81.
} 
akrosztichonnal. Feltehetően ez a toldalék a fentebb elemzett tendencia része, mikor is népszerűvé válnak az éneket összegző, vagy doxológiát közlő záró versszakok. Mindenesetre megállapíthatjuk, hogy a források közül egyik sem ad tökéletes akrosztichont, sem a kéziratos, sem a nyomtatott variánsok, ráadásul mindegyik el is tér egymástól.

A Ghiczy Jánosnak tulajdonított Ilyen fogadást tön a szent Dávid... incipitü zsoltárparafrázis (RPHA 573) kéziratos forrásban csak az unitáriusoknál fordul elö, a Bölönikódexben és a Csonka antifonáléban. Mindhárom 17. századi unitárius gyülekezeti énekeskönyv is tartalmazza, s elöttük egyetlen nyomtatott forrása ismeretes az 1602-es debreceni református gyülekezeti énekeskönyvből, ám sajnos e nyomtatvány egyetlen ismert példánya éppen ennél az éneknél csonkult. Az RPHA a későbbi debreceni énekeskönyvek variánsa alapján akrosztichonnak a következőt adja meg: IEANNES GICSII. A második strófa kezdő $E$-je egy ideálisan elképzelt szerzői variánsban nyilván $\mathrm{O} / O ̈$ lehetett, ugyanis a strófa első sora modernizált átiratban a következö: Örök Atya Isten, amíg élek, csak téged tisztellek...

$\mathrm{Az}$ eoreok/örök írásmód eltérésének számításba vételével így az akrosztichon jól rekonstruálható Iohannes-re. (Más kérdés, hogy az 1697-es unitárius énekeskönyvben az akrosztichon végképp elromlik azzal, hogy a második versszak eleje Kegyes Atya Isten... lesz.) A vezetéknév utolsó két $I$-jéből az egyik itt is a zsoltár mondandójának összegző strófája:

Így könyörge Dávid maga felöl a nagy Úristennek,/ példáját megírá ez énekben jó fejedelmeknek,/ hallgassa meg isten kérését a keresztyéneknek.

Nem egészen világos, hogy milyen nevet takar pontosan a MIKLOS CHASEE akrosztichonú, Mint kívánkozik a szarvas... kezdetü zsoltárparafrázis (RPHA 996), amelyben a CHASEE második E-je az 1560-as óvári nyomtatott megjelenésétől kezdve mindig hivatkozó strófát takar, tehát feltehetően itt is a Vadai által pótlásnak nevezett betűismétlő megoldással állunk szemben. Az is látható, hogy az 1560-tól gyakorlatilag minden általunk vizsgált nyomtatott énekeskönyvben szereplő szövegnek már a legelső kiadása olyan nevet hoz, amely feltehetően az akrosztichon elvétésével alakult ki, mégsem állítja azt helyre egyik nyomtatvány kiadója, szerkesztője sem. Valószínü, hogy az akrosztichon pontossága nem volt annyira fontos (így mnemotechnikai szerepe sem), mint a gyülekezet által ismert variánsok viszonylagos megőrzése.

A példákat szaporítja a Dicsérd az Istent, ó, én lelkem... kezdetű zsoltárparafrázis is, (RPHA 251) amely az 1579-es debreceni református énekeskönyvben található meg először nyomtatva. Az akrosztichonja az RPHA szerint a következő: D MEA MEVS. Igen valószínü, 
hogy már az első kiadásból is hiányoznak versszakok az akrosztichon alapján. Az RPHA nem említi viszont, hogy minden forrásban található a végén egy záró doxológia is, amelynek kezdete: Uralkodol te azért... Ez a zárás nem illeszthető az akrosztichonba, viszont úgy tűnik, a legelső forrástól része az éneknek. E szöveg történetében sem találunk viszont a rekonstrukcióra irányuló törekvést.

A Sztárai Mihály szerezte Sokan vannak most... kezdetű zsoltárparafrázis (RPHA 1283) némileg kilóg ebből a sorból, ugyanis a STARINUS akrosztichont az 1582-es detrekői megjelenésétől kezdve mindenütt tartja a szöveg. Kivétel ez alól az utolsó két strófa, amely mindenütt megtalálható, s a legtöbb helyen a következőre változtatják az RPHA által megadott akrosztichont: STARINUSIE. Az E-vel kezdődő záró versszak itt is hivatkozó strófa, ám pont a legelső kiadás eltér a többitől. Míg a STARINUSIE akrosztichon esetében az utolsó versszak az Ez éneket a szent Dávid próféta... sorral kezdi, addig az 1582-es detrekői kiadás Lám ezeket a szent Dávid próféta... sorra változtatja, így az -é, vagy -jé birtokjelet elhagyja. Nem valószínű, hogy az 1582-es detrekői énekeskönyv szerkesztője, Bornemisza Péter nem ismerte az akrosztichon-használat korabeli szokásait, sokkal valószínübb, hogy a szerkesztő itt sem az akrosztichon pontos megtartását tartotta a legfontosabb feladatnak a szövegrögzítés során.

A fent említett példák alapján úgy tűnik, hogy meglepő módon az akrosztichonok mnemotechnikai szerepe kevés hangsúlyt kap a gyülekezeti éneklés szempontjából, mi több, az énekek többsége már eleve romlott akrosztichonnal kerül be ebbe az énekhagyományba, amelynek a rekonstrukciójára nem találunk kísérletet annak ellenére, hogy az akrosztichonhasználatot jól ismerő szerkesztők, kiadók, másolók kezében forognak a szövegek.

\section{II. 4. Strófacserék, strófák kivétele és betoldása a gyülekezeti énekek variánsaiban}

A vizsgált anyagban nem ritka, hogy egyes források a nagy többséghez képest a strófák sorrendjét felcserélik. Ez bizonyos esetekben ugyanazon a protestáns vonalon tovább is hagyományozódik, ahogyan azt majd látni fogjuk. A strófák elhagyása is gyakori jelenség, ennek a leggyakrabban a már kifejtett, a kolofonokat érintő változás az oka, vagyis a referenciális strófák eltávolítása igen gyakori. Egy-egy strófa elhagyása jellemzően dogmatikai okokból is történhet: az unitárius variánsoknál gyakoribb, hogy a Krisztus 
istenségét vagy az eredendő bűnt említő versszakokat kihagyják, mintsem megváltoztatnák azt. Ugyanígy igen gyakori náluk a záró doxológia elhagyása is.

Azt, hogy a szövegek a nyomtatott hagyomány mellett feltehetően számos variánsban léteztek, alátámasztja a Palatics György énekeként ismert Uram, benned még az én reménységem... kezdetü ének is (RPHA 1425). Az akrosztichonján is látszik, (az RPHA alapján, feltehetően az általunk nem vizsgált Palatics-kódexből véve (S 3): V PALATICH GyÖrGI SzSzERSzEMTTEM) ${ }^{378}$ hogy az ének már a legelső, 1574-es komjáti kiadásban való megjelenésekor is jelentős változáson esett át, ennek az akrosztichonja: U PALATICH GyÖRGI SzHE. ${ }^{379}$ Jelentős rövidülés ez, amelyet a református gyüjteményeken kívül (az 1579-es debreceni nyomtatvány és a Detsi-kódex) minden egyes forrás eszközölni fog. Ám a könyörgést sokkal hosszabban hozó variánsokról sem mondható el, hogy közvetlen kapcsolta áll fenn köztük: az 1579-es kiadáshoz képest a Detsi-kódexbe 1609-ben bemásolt variáns számos helyen eltérést mutat: a 10 közös strófában összesen hét eltérés található. E két forrás túl az említett 10 strófán még egy plusz strófát közöl a kolofonstrófa előtt. Ezáltal az 1579-es debreceni kiadás és a Detsi-kódex akrosztichonja a következö: U PALATICH GyÖRGI SzSzERSzEMTTECHAE. A könyörgés hosszúságára egyébként maga az ének is tartalmaz önreflexív utalást: „Tovább immár beszédemet nem nyújtom, könyörgésemnek summáját megmondom ..."

Az akrosztichonban a név után közvetlenül következő két $S z$-szel kezdődő strófa mutatja igazán azt, hogy feltehetően erős variánsaiban élt a szöveg. Az első $S z$-szel kezdődő strófa, amely minden egyes forrásban megtalálható a következő: $:^{380}$

Szívem mert ${ }^{381}$ meghasad $^{382383}$ nagy bánatimban,/ hogy ${ }^{384}$ nincs részem a napnak világában,/ én tagaim ${ }^{385}$ vannak nagy fájdalomban,/ nehéz vasnak alig hordozásában. ${ }^{386}$

\footnotetext{
$378 \mathrm{Az}$ ének a bővítéseken túl jól példázza az akrosztichonok változását is: már a legkorábbi forrású szövegváltozatunkról is joggal feltételezzük, hogy bővült, hiszen az akrosztichon ebben az esetben még könnyen rekonstruálható. Az első strófa és az egyik $S z$, illetve az egyik $M$ kivételével akrosztichonként a következőt kapjuk: Palatics György szerzettem.

${ }^{379}$ A jelentős szövegváltozás kiemelése mellett érdemes azt is megjegyezni, hogy ez az ének a kolofon tanúsága szerint 1570-ben íródott, s ehhez képest egy magánjellegü könyörgés 1574-re már erős változatban jelenik meg gyülekezeti énekeskönyv szövegeként. Ez alapján ismét megállapíthatjuk, hogy a korban valószínüleg sokkal gyorsabban váltak a közösség számára ismertté bizonyos szövegek, mint ahogyan azt ma a rendelkezésünkre álló források alapján kikövetkeztethetjük.

Az ének ennyi strófával, ilyen akrosztichonnal található meg a következő nyomtatványokban: 1574 Komjáti; 1582 Detrekő; 1593 Bártfa; 1602-15 Kolozsvár; 1632 Kolozsvár. Az 1697-es kolozsvári unitárius kiadás is ugyanezt hozza, de a kolofonstrófát már elhagyja a végéről. Ez az 1697-es kiadásra szinte teljesen általánossá válik: ahol esetleg a 17. század végéig megmaradt a kolofon, azt az 1697-es kiadás már nem közli.

${ }^{380} \mathrm{Az}$ 1602-15 közötti unitárius variánst hozom föszövegként, de a vizsgált forrásokban található eltérést lábjegyzetben közöljük.

${ }^{381}$ nincs mert: 1602-14 Bártfa.
} 
A következő, szintén $S z$-szel kezdődő versszak már csak a Detsi-kódexben és az 1579es debreceni kiadásban található meg, de gyakorlatilag az imént idézett strófa erős átköltéseként értelmezhető, s mint ilyen, a strófa mondandója e két forrásban duplán fordul elö. Az is látható, hogy a hasonló jelentésü versszak e két forrásban is jelentős eltéréssel szerepel, így nem közvetlen a leszármazás. ${ }^{387}$

Szivemet lássad meg ${ }^{388}$ nagy bánatjában,/ hogy ${ }^{389}$ nincs részem nekem már e világban,/ nincs örömem keserü ${ }^{390}$ kínjaimban,/ minden napon tartom lelkem markomban.

A legtöbb gyülekezeti énekeskönyv ezt az éneket a könyörgés részletezésénél rövidítve közli tehát, és azt is láthatjuk, hogy van olyan forrás, melyben egy strófának az erös átirata is megtalálható, közvetlenül a versszak után.

A Segitségül hívjuk a mennybéli Istent... (RPHA 1215) az 1569-es debreceni kiadástól kezdve minden általunk vizsgált gyülekezeti énekeskönyvben megtalálható, s a korabeli kéziratos források közül is megvan a Csonka antifonáléban, a Bölöni-kódexben, s megvolt a Vasady-kódexben illetve a Toroczkai Máténak másolt graduálban. Az ének azért is érdekes lehet, mert az egyes felekezetek különböző szöveghagyományai jól elkülönülnek egymástól, mi több, a debreceni református kiadásokban még az is megfigyelhető, hogy az 1590-es és az 1602-es énekeskönyv variánsai eltérnek a korábbi debreceni kiadások variánsaitól. Ennek ellenére azt látjuk, hogy az 1602-14-es bártfai evangélikus kiadás nem követi az 1593-as bártfai evangélikus kiadás variánsát, számos ponton eltér attól. A szórendcseréiről a későbbiekben lesz még szó, fontos azonban megemlíteni, hogy az 1602-14-es bártfai nyomtatvány tartalmaz három olyan strófát, amely másutt sehol nem fordul elő. A vizsgált nyomtatványok közül a bártfai az egyik legkésőbbi nyomtatvány, ennek ellenére úgy tünik, teljesebb változatot közöl, mint a többi gyülekezeti énekgyüjtemény. Az ének az Istenbe vetett bizodalomról szól: ha gondunk, bajunk van, mindig az Úristenhez forduljunk. Az Úristen segítségnyújtására az ének példákat is hoz: Isten Józsefet is kimentette Egyiptomból, a pásztor Dávidot pedig királlyá tette, a példák is mutatják tehát, hogy mi is bízhatunk az Úr segítségében.

\footnotetext{
382 a Szívem mert meghasad... helyett a Detsi-kódexben a következő található: Szívemet lássad meg...

383 meghervadt: 1579 Debrecen; 1593 Bártfa; 1602-14 Bártfa.

${ }^{384}$ mert: Detsi-kódex; 1579 Debrecen.

385 tetemim: Detsi-kódex; 1579 Debrecen.

386 fordulásában: Detsi-kódex, 1579 Debrecen.

${ }^{387}$ Az 1579-es debreceni kiadás változatát idézzük, s lábjegyzetben jelöljük a Detsi-kódex eltéréseit.

${ }^{388}$ Szivem mert hervadt: Detsi-kódex.

389 mert: Detsi-kódex.

${ }^{390}$ keserves: Destsi-kódex.
} 
Az 1602-14 közötti bártfai kiadásban a József és Dávid példáit részletező strófák közé beékelődik három plusz strófa, ezek közül egy szent Illésről, egy a tüzes kemencébe került három férfiről, egy pedig Dánielről és az oroszlánról szóló történet részletezését adja. Bővítmény tehát, amely a 17. század elejéig egyik forrásban sincs meg, mégis elképzelhető, hogy egy kvázi szerzői variánsban benne lehetett az Isten segítő volát bibliai példákkal alátámasztó kifejtés, melyet a nyomtatott hagyományba már nem vettek fel a terjedelem miatt. Nem kizárt tehát, hogy az 1602-14 közötti bártfai kiadás bővítménye tulajdonképpen a többi gyülekezeti énekgyüjtemény rövidítő eljárását mutatja.

A strófák kiesése a legtöbb esetben feltehetően azért következett be, mert az ének túl hosszú volt az énekléshez. Így egy-egy funkció - pl. könyörgés, vagy példák felsorolása rövidítésével az ének lényegi mondandója nem csonkult, de a hosszúságból el lehetett venni. Az, hogy az általunk vizsgált egyik legkésőbbi, 1602-14 közötti bártfai kiadás hoz egy bővebb variánst, még nem jelenti azt, hogy ez utólagos betoldás, mi több, valószínü, hogy eredetileg is szerepelhettek ezek a strófák a szövegben. Így számolhatunk azzal, hogy egy kései kiadás is lehet egy az „eredetihez” közel álló variáns hordozója. Az exemplum, a részletezés kikopása a gyülekezeti énekből poétikai értelemben is szegényíti a szöveget, de meg kell jegyeznünk, hogy sok esetben a kikopás által fog a közhelyszerü teológia érvényesülni, és/vagy a bibliai szövegekhez közelebb álló változat keletkezni. Ez a poétikai egyszerüsödés, teológiai közhelyszerüség a használatból, a gyülekezet általi énekeltségböl fakadhat.

\section{V.II. 5. A rím és a ritmus változása a gyülekezeti énekben}

A nyomtatott gyülekezeti énekgyüjtemények egyike sem mondható teljesen „hibátlan,” rímben és ritmusban következetesen tökéletes megoldásokat alkalmazónak. Noha a ,javító” szándék a legtöbb gyüjtemény esetében megfigyelhető, - ha egy-egy felekezeti énekeskönyv egyik kiadása rontott ritmust vagy rímet közölt egy adott énekben, az általánosnak mondható, hogy a következő kiadás javítja, - ám másutt újabb rontásokat egy éneken belül is igen gyakran tartalmaznak a gyüjtemények.

Éppen ezért feltételezhetjük, hogy a ritmus tekintetében a legtöbb szöveg énekeltségében nem az egy szótag = egy ritmus/egy hang elve alapján hangozhatott el, hiszen az egyes énekek szinte minden kiadásában találunk olyan, általunk ma rontott vagy hibás 
szótagszámúnak vélt sort vagy sorokat, amelyek, ha énekelve az egy szótag = egy ritmus elve szerint hangoztak volna el, előbb vagy utóbb nyilvánvalóan ki lettek volna ,javítva” helyes szótagszámúra. Úgy tünik azonban, hogy ezek következetesen és konzekvensen egyik vizsgált énekgyüjteményre sem jellemzők.

Noha Újfalvi Imre 1602-es énekeskönyve például kifejezetten figyel a rím és a ritmus javításaira még ott is, ahol a viszonylag sok ilyen jellegü „hibát” tartalmazó 1569-es debreceni énekeskönyv szövegeit a későbbi debreceni kiadások sem javították, ennek ellenére még Újfalvi Imre énekgyüjteménye is gyakran vesz be újabb „hibás,” nem megfelelő szótagszámú vagy rímü sorokat, strófákat. Az oppenheimi biblia utáni gyülekezeti énekekre ez a tendencia szintén jellemző: számos helyen jobb variánst hoz ritmus tekintetében az előző kiadásokhoz képest, ám saját „hibákat” ugyanúgy tartalmaz.

Példa erre a Mire bánkódol, ó te, én szívem... kezdetü zsoltárparafrázis (RPHA 999). A korszakunkból ez az ének az 1590-es debreceni református kiadásban szerepel először, majd az 1612-es oppenheimi kiadásban és az unitárius gyülekezeti énekeskönyvekben. Az ének metruma az RPHA alapján a következö: a10 (5,5), a10 (5,5), x6, b8 (4,4,), b8 $(4,4)$.

A kezdősor metrumának már az incipit sem felel meg: egészen az 1632-es kolozsvári unitárius kiadásig minden forrásban a következő szerepel az idézett incipit helyett: Mire bánkódol, ó én szívem? Kimarad tehát egy szótag. A második strófa első sora viszont csak az oppenheimi kiadásban szerepel helyes ritmussal, s egyben helyes rímmel is, a további forrásokban sem a ritmus, sem a rím nem jön ki:

1612, Oppenheim: A nagy Úristen nem hagy tégedet, / tudja ö minden szükségedet...

1590, Debrecen: 1602-15 Kolozsvár: Nem hagy téged a nagy Úristen,/ tudja ö minden szükségedet...

A harmadik strófa elejét is csak az oppenheimi kiadás hozza jó ritmussal, s az ének még több ponton tartalmaz olyan metrumbeli eltéréseket, amelyekben csak az oppenheimi kiadás hoz helyes szótagszámot. Azt gondolhatnánk, hogy ez egy jó, újonnan beépített forrásnak vagy a korrigálásnak az eredménye lehet, ám meg kell említeni, hogy több ponton az oppenheimi kiadás lesz az, amely eltér a metrumtól. A hetedik strófa utolsó elötti sora például olyan, amely egyik kiadásban sem tartja a rímet, s a szótagszám is csak az 1590-es debreceni kiadásban 8-as - itt az utolsó két b8, b8-as párrímes sorról van szó. A strófa utolsó két sora a következő variánsokban fordul elő:

1590, Debrecen: de néki eledelt külde,/ szolgájától Habakuktól.

Itt a szótagszám helyes, de nem rímel.

1612, Oppenheim: de néki ételt külde/ szolgájától Habakuktól. 
Itt a szótagszám és a rím sem jön ki annak ellenére, hogy a többi strófa valóban tartani látszik a metrumképletet. Ugyanez a helyzet az unitárius gyülekezeti énekek esetében is:

1602-15, Kolozsvár: de őnéki eledelt külde,/szolgájától, Habakuktól.

Látható, hogy minden egyes forrás apró, de rokon értelmű eltéréseket tartalmaz egymáshoz képest, ám a rím és a ritmus együttese egyik forrásban sem helyes.

A 11. versszak utolsó sorában az oppenheimi kiadás hoz rossz szótagszámot, ám az unitárius énekeskönyv variánsa a szótagszám betartása mellett is eltérő, de gyakorlatilag azonos jelentésű sort hoz, mint a másik két kiadás, s a szótagszámot őrzi:

1590, Debrecen: Uram, hogy én veled legyek. - Helyes, 8 szótagos sor.

1612, Oppenheim: Uram, hogy veled legyek. - Egy szótaggal kevesebb.

1602-15, Kolozsvár: hogy én teveled lehessek. - A szótagszám helyes, de más szórend illetve más rokon értelmü sor szerepel, mint a szintén pontos szótagszámú debreceni kiadásban.

Úgy véljük, ezek az eltérések is abba az irányba mutatnak, hogy a gyülekezeti énekek szövegváltozásainál szükségszerü egy olyan, alapvetően az éneklésben meglévő hagyománnyal is számolnunk, amelyet ma már nem tanulmányozhatunk, hiszen az énekelt formáknak csak szórványosan rögzített, nyomtatott vagy kéziratos leképezése maradt fönn mára. $^{391}$

A szövegváltozások többi jellegzetességéhez hasonlóan a rím és a ritmus változásai is olyanok, amelyek csak önálló dolgozatban lehetnének kellő mélységben kifejthetők. Mindenesetre a dolgozat vizsgált énekanyagán megfigyelhetők az elmondottak, azaz hogy egyik forrás sem tartalmaz minden szempontból tökéletes metrumot hozó énekeket.

A rím és a ritmus alapvetően az éneklést, a fejben tartást segítő eszközök. Ennek ellenére néhány ének, amelyet ma rímtelen, de verses szövegként határozunk meg, már a kezdetektől a gyülekezeti énekgyüjtemények része volt, rímtelen volta ellenére. A következőkben olyan példákat mutatunk be, amelyek ellentétben azzal, amit várhatnánk, - t. i. a gyülekezeti ének a könnyebb fejbentartás miatt rímes - rímtelenül hagyományozódnak közel ötven éven keresztül, s a későbbiek folyamán igyekeznek rímessé tenni azokat - kevés sikerrel.

A betoldott - avagy kiesett - strófák ismertetésénél volt szó a Segítségül hívjuk a mennybéli Istent... kezdetű ének (RPHA 1215) 1602-14 közötti bártfai variánsáról, mely az

\footnotetext{
${ }^{391}$ Természetesen az ilyen esetekben a nyomdahibával is számolnunk kell. A kérdés azért is összetett, mert feltételezhetjük, hogy Szenci Molnár Albert különösen érzékeny volt a rím és a ritmus tartására, s azt is tudjuk, hogy a nyomdász nem magyar volt.
} 
előző számos kiadáshoz és kézirathoz képest ${ }^{392}$ három plusz strófát tartalmaz. Úgy tűnik azonban, hogy ezek a plusz strófák az ének mondandóját bibliai példákkal alátámasztó részek. Feltételezhető, hogy az exemplum, amelyből a hívek tanulhatnak, eleve része volt az éneknek, csak egy rövidítés során a strófák kikoptak - öt bibliai példából kettő maradt meg csupán. A bártfai énekeskönyv viszont beveszi a feltételezhetően már korábban is létezett három példát, három strófával bővítve az éneket. Így a bártfai gyüjtemény bővítése egy feltételezhetően korábban bekövetkezett szükítés, amelyet majd ez a kiadás old fel ismét. Ezt az állítást alátámasztja a szöveg metruma is: az RPHA szerint a változatok alapján a metruma x12 $(6,6$,$) ,$ x12 $(6,6),, x 12,(6,6)$, x12 $(6,6)$. Tehát olyan felező tizenkettesekböl áll, amelyek nem rímesek.

A körülbelül ötven éven átívelő szövegvariánsok közül az 1602-14-es bártfai kiadásé a legeltérőbb, de ahogyan arra a későbbiekben majd kitérünk, némely debreceni kiadások illetve az 1574-es komjáti és az 1582-es detrekői, valamint az unitárius variáns egymástól is eltérő, külön-külön, csoportonként egymással rokonságot mutató változatok. Ám ezek az említett kiadások mind tartják a rímtelen felező tizenkettes metrumot a szövegbeli eltérések ellenére.

Noha az 1602-14 közötti bártfai kiadás, ahogyan említettük, jórészt az 1593-as bártfai kiadásra épít, s annak az evangélikus gyülekezeti énekhasználatnak a leszármazottja, szövege mégis jelentősen eltér attól, sőt, a metruma is másképp definiálható: a legtöbb esetben bokorrímes felező tizenkettes, vagy páros rímü felező tizenkettes.

Az alábbi táblázat első oszlopában a szöveg legelső fennmaradt nyomtatott forrását, az 1569-es debreceni kiadás variánsát hozzuk, a második oszlopban pedig az 1602-14 közötti bártfai kiadásét, amely a korábbi variánsokhoz képest rímes formában található meg az énekgyüjteményben.

\begin{tabular}{|l|l|}
\hline \multicolumn{1}{|c|}{ 1569, Debrecen, 177. } & \multicolumn{1}{|c|}{ 1602-14, Bártfa, 258. } \\
\hline $\begin{array}{l}\text { Segítséggel hívjuk a mennybéli Istent, } \\
\text { hogy minket ne hagyjon nyomorúságinkban, } \\
\text { bátoritson minket az ö szent lelkével, } \\
\text { távol járjon tölünk a nagy hitetlenség. }\end{array}$ & $\begin{array}{l}\text { Segítségül hívjuk a mennybéli Istent, } \\
\text { az ö szent lelkével minket bátoritson, } \\
\text { a nagy hitetlenség tölünk távol járjon. }\end{array}$ \\
\hline
\end{tabular}

\footnotetext{
392 Ahogyan azt az előző alfejezetben említettük, az ének kéziratos forrásai a következők: Bölöni-kódex (S 30); Vasady-kódex; Csonka antifonálé (S 143), s megvolt a Toroczkainak másolt graduálban (H 31) is. Nyomtatott forrásai a következők: 1569, Debrecen; 1570, Debrecen; 1574, Komjáti; 1582, Detrekő; 1590, Debrecen; 1593, Bártfa; 1602, Debrecen; 1602-14 Bártfa; 1602-15, Kolozsvár.
} 


\begin{tabular}{|c|c|}
\hline $\begin{array}{l}\text { Parancsolja Isten nyomorúságinkban, } \\
\text { hogy csak ötet hívjuk hitböl segítségre, } \\
\text { irván hagyta nékünk Szent Dávid könyvében, } \\
\text { senkinek nem illik róla kételkedni. }\end{array}$ & $\begin{array}{l}\text { Isten parancsolja Szent Dávid könyvében, } \\
\text { hogy csak ötet hívjuk hitböl segitségre, } \\
\text { meghallgat minket minden szükségünkben, } \\
\text { szent dicséretiért nem hagy veszedelemben. }\end{array}$ \\
\hline $\begin{array}{l}\text { De a hitetlen szív mindenkor gondolja, } \\
\text { hogy elfeledkezett róla Úristen, } \\
\text { és hogy ötöle messze eltávozott, } \\
\text { nem várhat ötöle mennyböl segítséget. }\end{array}$ & $\begin{array}{l}\text { De a hitetlen szív mindenkor gondolja, } \\
\text { hogy elfeledkezett Úristen öróla, } \\
\text { és igen messze eltávozott ötöle, } \\
\text { nem várhat mennyböl segítséget ötöle. }\end{array}$ \\
\hline $\begin{array}{l}\text { Szükség azért hinni minden nyomorultnak, } \\
\text { hogy Isten szemei mennyből reá néznek, } \\
\text { és kimenti ötet minden nyavalyából, } \\
\text { de határt ne vessen ő segitségének. }\end{array}$ & $\begin{array}{l}\text { Szükség hát hinni minden szükölködönek, } \\
\text { hogy Isten szemei mennyböl reá néznek, } \\
\text { elfordítja nyavalyáját életének, } \\
\text { de határt ne vessen ö segítségének. }\end{array}$ \\
\hline $\begin{array}{l}\text { József pátriárkát Egyiptom országban, } \\
\text { két esztendeig ott tarták fogságban, } \\
\text { onnan Isten őtet el-kiszabadítá, } \\
\text { Egyiptom országban fejedelmül tevé. }\end{array}$ & $\begin{array}{l}\text { József pártiárkát Egyiptom országban, } \\
\text { két esztendeiglen ott tarták a fogságban, } \\
\text { Isten kiszabaditá hozzá biztában, } \\
\text { fejedelemmé tevé Egyiptom országban. }\end{array}$ \\
\hline- & $\begin{array}{l}\text { Szent Illyést amaz igen nagy drágaságban, } \\
\text { egy özvegyasszony táplála Sareptában, } \\
\text { kihez Illyés Istentöl küldetett vala, } \\
\text { három esztendeig esö nem lett vala. }\end{array}$ \\
\hline- & $\begin{array}{l}\text { A kegyelmes Úristen el sem felejté, } \\
\text { a három férfiat égő kemenécben, } \\
\text { Szent angyalát elküldé, a tüztől megörizé, } \\
\text { és őket a veszedelemböl megmenté. }\end{array}$ \\
\hline- & $\begin{array}{l}\text { Dánielt is a jó Isten nem hagyá, } \\
\text { mikor az oroszlánok között ül vala, } \\
\text { ő szent Angyalát idején elbocsátá, } \\
\text { Habakuk által néki ételt hordata. }\end{array}$ \\
\hline $\begin{array}{l}\text { Dávid pásztor vala, de nagy csodaképpen, } \\
\text { ötet felválasztá király felségére, } \\
\text { és mind holtáiglan lőn neki oltalma, } \\
\text { mert Istenben vala neki bizodalma. }\end{array}$ & $\begin{array}{l}\text { Csodaképpen Dávidot, ki pásztor vala, } \\
\text { az Isten királyi felségre választa, } \\
\text { és mind holtáiglan lön neki oltalma, } \\
\text { mert Istenben vala neki bizodalma. }\end{array}$ \\
\hline Minket is nem hagy el a felséges Isten, & A felséges Isten minket nem hagy el, \\
\hline
\end{tabular}




\begin{tabular}{|c|c|}
\hline $\begin{array}{l}\text { mert igéretivel ö magát kötelezte, } \\
\text { csak vessük öbenne mi reménységünket, } \\
\text { e világon leszen mi kegyelmes Atyánk. }\end{array}$ & $\begin{array}{l}\text { mert magát kötelezte igéretivel, } \\
\text { csak töle várjunk igaz reménységgel, } \\
\text { mi kegyelmes Atyánk lészen ö, nem hagy el. }\end{array}$ \\
\hline $\begin{array}{l}\text { Jusson jól eszünkbe }{ }^{393} \text { szent Péter mondása, } \\
\text { holott ö azt írja egyik levelében, } \\
\text { Istenbe vessétek szorgalmatosságtokat, } \\
\text { mert öneki vagyon mirólunk nagy gondja. }\end{array}$ & $\begin{array}{l}\text { Szent Péter mondása jusson jól eszedbe, } \\
\text { holott ö azt írja egyik levelében, } \\
\text { szorgalmatosságtok vessétek Istenbe, } \\
\text { mert néki vagyon rólunk gondja életünkben. }\end{array}$ \\
\hline $\begin{array}{l}\text { Krisztus azt mondja evangéliumban: } \\
\text { hogy étünkröl, itunkról és ruházatunkról, } \\
\text { nekünk ne legyünk szorgalmatosságáról } \\
\text { [sic!], }{ }^{395} \\
\text { hanem kiváltképpen Isten országáról. }\end{array}$ & $\begin{array}{l}\text { Krisztus az Evangéliumban int bennünk, } \\
\text { hogy étünkre, itunkra ne legyen föbb } \\
\text { gondunk, } \\
\text { s ruházatunkról se szorgalmatoskodjunk, } \\
\text { hanem Isten országát elöbb keressük. }\end{array}$ \\
\hline $\begin{array}{l}\text { Azért adjon isten nekünk igaz hitet, } \\
\text { szívünkből kivesse nagy hitetlenséget, } \\
\text { szomorúságinkban vigasztaljon minket, } \\
\text { halálunk óráján legyen mimellettünk. }\end{array}$ & $\begin{array}{l}\text { Azért adjon nekünk Isten igaz hitet, } \\
\text { szívünkből kivegye a hitetlenséget, } \\
\text { szomorúságinkban vigasztaljon minket, } \\
\text { halálunk óráján legyen mimellettünk. }\end{array}$ \\
\hline
\end{tabular}

Az 1602-14 közötti bártfai kiadás ebben az esetben tehát - ahogyan azt az előző fejezetben bemutattuk - tartalmaz többletstrófákat, amelyek exemplumok, s a szórendcserék által szinte mindenütt rímes strófákkal találkozunk - szemben a többi variáns többé-kevésbé rímelő soraival.

Ugyanilyen típusú ének rímelés szempontjából a Jer, emlékezzünk, keresztyén népek... kezdetű zsoltárparafrázis is (RPHA 0645), mely már az 1560-as óvári kiadásban, az első nyomtatott forrásban is csak nyomokban tartalmazott rímeket. Az RPHA a metrumképletét éppen ezért x10, x11, x10, x11-esként definiálja. ${ }^{396}$ Az egyáltalán nem rímelő strófák szintén

\footnotetext{
393 Többes szám első személyt csak az 1569-es és az 1570-es debreceni kiadás használ, a többi kiadás feltehetően visszatér, de mindenképp megváltoztatja egyes szám második személyüre. A közösség igényének a két debreceni kiadás jobban megfelel, ennek ellenére a többi kiadás visszatér a tanító jellegü E./2-re.

${ }^{394} \mathrm{Az}$ 1602-14-es bártfai kiadáson kívül csak az unitárius nyomtatványok és kéziratok térnek el, ezek a mi helyett $t i$-t, többes szám második személyt használnak.

395 Az 1570-es kiadás is átveszi még, de a többi kiadásban már szorgalmatosságunk szerepel.

${ }^{396} \mathrm{Az}$ 1560-as óvári kiadáshoz hasonló, rímeket alig tartalmazó változatok találhatók a következő kéziratos forrásokban: Csonka antifonálé (S 143); Kassai István énekgyüjteménye (H 32). A nyomtatványok szintén alig rímelő strófákat tartalmaznak: 1560 Óvár, 1566 Várad (ebben kétszer, két egymástól apróbb eltérésekben különböző variáns van az énekből); 1569 Debrecen; 1570 Debrecen; 1574 Komjáti; 1579 Debrecen; 1582 Detrekő; 1590 Debrecen; 1593 Bártfa; 1602 Debrecen; 1602-14 Bártfa; 1602-15 Kolozsvár, s ez utóbbi nyomán 1632 Kolozsvár és 1697 Kolozsvár.
} 
az 1602-14 közötti bártfai evangélikus kiadásokban válnak a szórend megfordításával, megvariálásával rímessé. Ilyen például az 5. a 6 . és a 7. versszak. Alább ezeket előbb a legkorábbi, az 1560-as óvári kiadásból, majd az 1602-14-es bártfaiból közöljük.

\begin{tabular}{|l|l|}
\hline \multicolumn{1}{|c|}{$\mathbf{1 5 6 0}$ Óvár, Kassa, Debrecen } & \multicolumn{1}{c|}{$\mathbf{1 6 0 2 - 1 4 \text { Bártfa }}$} \\
\hline 5. Íme, keresztyén, mely nagy örömünk & Íme, keresztyén, mely nagy örömünk \\
vagyon minekünk a nagy Úristenben, & a nagy Úristenben vagyon minekünk, \\
mert nem aluszik, csak reánk vigyáz, & mert nem aluszik, csak vigyáz reánk, \\
és csak ö minket öriznie akar. & örizni akar, csak szavát fogadnánk. \\
\hline 6. Áldott Úr Jézus ${ }^{397}$ megöriz téged, & Áldott Úr Jézus megöriz téged, \\
és el-befedez az ö szent kezével, & az ö szent kezével befedez téged, \\
minden terhedet ö elviseli, & ö elviseli minden terhedet, \\
és elfedezi a te büneidet. & és elfedezi a te büneidet. \\
\hline 7. A Nap a napon téged el nem ront, & A Nap a napon el nem ront téged, \\
és az éjszakán a Hold el nem emészt, & éjszaka a Hold el nem emészt téged, \\
mert az Úristen tégedet megöriz, & mert az Úristen megöriz téged, \\
minden gonosztól lelkedet megmenti. & minden gonosztól megmenti lelked. \\
& \\
\hline
\end{tabular}

E pár példából is látható, hogy a bártfai kiadás itt is vagy páros rímü, vagy aaaa rímképletet adó strófákat közöl, amely néhány szórendi cserével elérhető. Úgy gondolhatnánk, hogy a „rímesebb” variáns az éneklés, a fejbentartás szempontjából jobb, hiszen a gyülekezeti számára könnyebben megjegyezhető. Éppen ezért érdemes megvizsgálni, hogy az 1602-14-es bártfai énekeskönyv rímes variánsai után a következő evangélikus énekeskönyvek melyik variánst fogják alkalmazni: a protestáns hagyományban régóta élő, nem rímes, kevesebb strófából állót, amelyet feltehetően ismer a gyülekezet, vagy az éneklés szempontjából praktikusabbnak tünő rímeset?

Az 1640-ben Bártfán kiadott evangélikus énekeskönyvben a Segitségül hívjuk... variánsa megtalálható a 437. laptól, a Jer, emlékezzünk... pedig a 478.-tól. A két szöveg variánsa alapvetően a korábbi források kevésbé rímes változatát hozza, ám a Segítségül hívjuk... esetében a kolofonstrófát ez a kiadás már az unitárius változatokhoz hasonlóan kihagyja, illetve mindkét szöveg variánsa tartalmaz saját változtatásokat is. Úgy tűnik tehát,

\footnotetext{
${ }^{397}$ Az unitárius források Jézus helyett Istenről beszélnek majd. Az ilyen, dogmatikai jellegű szövegváltozásokat a következő nagy fejezet tárgyalja.
} 
annak ellenére, hogy a rímes változat az énekek fejben tartását jobban segíthetné, a későbbi evangélikus kiadások mégsem ezt veszik át a gyülekezeti énekhagyományból, hanem azt, amely a protestáns énekhagyományban szinte a kezdetektől megtalálható, kevéssé rímes, strófák szempontjából pedig csonkult. Ha egy ének valamilyen formában rögzül a gyülekezeti éneklésben, - még ha ez a forma nem is tartalmazza az éneklést, a fejben tartást segítő jegyeket - akkor egy újabb, markáns eltéréseket tartalmazó variáns nagy eséllyel nem fog rögzülni a nyomtatott hagyományban, hiszen a hívek nem ezt a változatot szokták meg, nem ez hagyományozódott.

A messzemenő verstani következtetések levonását a teljes gyülekezeti énekkorpusz vizsgálata és kompetencia híján nem kíséreljük meg, de talán a felhozott néhány példa is rávilágít arra, hogy a rím és a ritmus még abban az esetben is igen képlékenyen viselkedik, ha közösség által énekelt, a közösség tagjai számára ismert énekekről van szó. Úgy gondolhatnánk, akárcsak az akrosztichon, a rím és a ritmus is olyan kapaszkodó, amely segíti az énekek fejben tartását, s akár magát az éneklést is, ám ezen jegyek is igen nagy variabilitást mutatnak az egyes fennmaradt forrásokban az akrosztichonhoz hasonlóan.

\section{II. 5. 1. Rímtoposzok és/vagy rímbokrok a gyülekezeti énekekben?}

Imre Mihály monográfiája ${ }^{398}$ részletező módon mutatja be Rimay János Ó szegény megromlott... kezdetü énekének első strófájában található nép-szép-kép-ép rím toposszá válását. A rímtoposszal [a] „Querela Hungariae toposz szuggesszív lírai változatát teremti meg Rimay, ”399 ahogyan azt Imre Mihály bemutatja. S valóban, a rímeket a legtöbb esetben az alakuló hazafias-politikai költészet fogja felhasználni, s ezáltal válik a rímtoposz tematikussá.

Rimay később igen nagy népszerüségnek örvendő rímeit ${ }^{400}$ az első között Thordai János használja fel az unitárius zsoltárfordítások során még Rimay életében, 1627 körül. ${ }^{401}$ Imre számadatai alapján Thordai tizenkilenc alkalommal használja fel a rímtoposzt, de már

398 IMre Mihály, „Magyarország panasza” A Querela Hungariae toposz a XVI-XVII. század irodalmában, Debrecen, 1995( Csokonai Könyvtár 5).

${ }^{399}$ IMRE, i.m., 263.

400 Imre Mihálytól némiképp eltérő módon, nem a rímtoposz dimenziójában, hanem a Rimay versek hagyományával illetve hagyományozódásával hozza összefüggésbe a fejezet által is felvetett problémát Szigeti Csaba. SziGETi Csaba, A Rimay-vershagyomány a XVII. században, ItK, 1982(86), 5/6, 614-619. SzIGETI Csaba, Appendix Balassiana, Kronológia, tradíció, hagyománytudat a XVII. századi Balassi-követö nemesi költészetben, ItK, 1985(89) 6, 675-687.

${ }^{401}$ IMRE, i.m., 254-55. 
variálja is azt. Noha a Thordai-zsoltárparafrázisok nem tekinthetők a hazafias vagy a politikai költészet darabjainak, a szükebb kontextusban a legtöbb esetben mégiscsak a zsidóság hazájára, vagy ellenségeire vonatkoztatott rímtoposz valamelyest rokon az eredeti tartalmi háttérrel.

Ilyen, már a lép szóval is bővített rímtoposz jelenik meg a 94. zsoltár hatodik strófájában Thordainál:

Oh balgatagságban megvakult bolond nép!

Keserü méreggel megtöltött undok lép,

Miért lehetsz olyan, mint egy faragott kép?

Nincs-é okosságod bolond észre költ nép? ${ }^{402}$

Látható, hogy itt a kép szó már az eredeti, fegyver jelentése helyett a faragott kép értelemben használatos.

$\mathrm{Az}$ Ó, szegény megromlott... incipitű Rimay-versnek egyébként más rímei is visszaköszönnek a Thordai-zsoltárokban. A 95. zsoltár utolsó strófája a következő:

A hitetlenség, engedetlenség mindent az Isten kedvétöl megfosztott,

A boldogságban, nyugalomban senkinek a bün soha részt nem osztott. ${ }^{403}$

A Rimay-vers utolsó előtti versszakában az osztó-fosztó rím más értelemben fordul elő, tehát Thordai a jelentésen itt is variál.

Szintén az Ó, szegény megromlott... incipitü versben, az utolsó strófában található meg a felem-telem-velem-jelem rímbokor, amelynek az utolsó rímpárja Thordai 119. zsoltárjában is megvan:

E földön amíg bujdosom, addig szólj, beszélj velem, Ezt beteg szívem álejtja, kedvem hogy szód légyen jelem. ${ }^{404}$

Thordai a zsoltáraiban előszeretettel alkalmazott Rimaytól vett rímeket, szóképeket, alakzatokat, ahogyan erre már Zentai Mária rámutatott. ${ }^{405} \mathrm{~A}$ különböző poétikai, retorikai eljárásokat azonban nem csak az istenes és/vagy a hazafias témájú Rimay-szövegekből veszi át Thordai, hanem ahogyan az említett tanulmányban olvashatjuk, ${ }^{406}$ a szerelmes és egyéb témájú versekből is merítenek a zsoltárok.

\footnotetext{
${ }^{402}$ Az RMKT 17/4. 149. számú verse, az átiratot ez alapján hozom.

${ }^{403}$ Az RMKT 17/4. 150. sz. verse alapján, 313.

${ }^{404}$ RMKT 17/4. 174. sz. 349.

405 ZENT AI Mária, Rimay hatás Thordai János zsoltáraiban = Acta Historiae Litterarum Hungaricarum, Tomus XIII. Szeged, 1973, 111-123.

${ }^{406}$ ZENTAI i.m.
} 
Az imént idézett velem-jelem rímpár visszaköszön a 86. zsoltár hatodik versszakában is, bár itt egyes szám második személyü raggal:

Nincsen tehozzád hasonló, Isten, senki nem ér veled,

Nagy hatalmadról és jó voltodról mindenütt sok jeled. ${ }^{407}$

Rimay Negyedik verse, a Mi lelt? Azt kérdhetnéd... kezdetü ötödik versszaka használja elöször a bírt-irt-hírt rímhármast. Thordai 63. zsoltárának hatodik versszaka átveszi e rímeket, ám ismét variál a szavak jelentésén. Rimay szerelmes verse a következőképp használja a rímeket:

Látnád, nem csudálnád, hogy engemet megbirt,

Mert ö ábrázatja mintegy arannyal irt,

Ékes állapatja felülmúl minden hírt. ${ }^{408}$

Az ir szó az írás helyett Thordainál gyógyító ir értelemben jelenik meg:

A te szerelmed szívemnek kövér sír,

Törvénybeli igéreted kedves hir,

Büneimnek szent Lelked gyógyitó ir,

Kegyelmed énbennem minden bünt megbir. ${ }^{409}$

Látható, hogy itt már a szerelmes tematikájú énekek rímeiből is kölcsönöz Thordai a zsoltárokhoz. Ugyanez a helyzet a 24. zsoltár 4. versszakában és a 99. zsoltár 7. strófájában is: a Szólitván nevemen... kezdetü, Első címet viselő Rimay-vers első versszakának egyik rímpárja a szavát-javát:
Szólítván nevemen
Venus asszony engem,
Kezdé haraggal szavát:
Csak te vagy-é, úgymond,
Oly eszes vagy oly bolond,
Hogy én hatalmam javát
Kis szóddal sem kéred,
Söt ottan keröled
Szerelem tág hálóját? ${ }^{410}$

Ez a rímpár Rimaynál fordul elő először, majd Thordainál kiegészítve találjuk meg a

24. zsoltárban:

\footnotetext{
${ }^{407}$ RMKT 17/4. 141. sz., 297.

${ }^{408}$ Rimay János írásai, szöveggondozás és utószó, Ács Pál, Bp., Balassi, 1992, 62.

${ }^{409}$ RMKT 17/4. 118. sz. 257.

${ }^{410}$ Rimay összes írásai, 57.
} 
Esküvéssel nem csalja meg soha atyafiát,

Amit fogad, megállja és megtökéli szavát,

Csalárdul nem öregbíti, sem nem bírja javát,

Az özvegyet megbecsüli, segíti az árvát. ${ }^{411}$

A 99. zsoltárban e két szó más szavakkal párosítva jelenik meg rímként:

Úristen, meghallád a te néped szavát,

És megadád neki az ö igért javát,

Irgalmasságodnak felemeléd szarvát,

Felségednek fogytig hogy ne látnák búvát. ${ }^{412}$

Összegezve az eddig hozott néhány példát - noha Thordai és Rimay között még számtalan ilyen, rímbeli áthallás található - azt mondhatjuk, hogy a Thordai-zsoltárok témára való tekintet nélkül használják fel Rimay rímeit.

\section{II. 5. 1. 2. Szava-sava-tava-java: egy nem tematikus rímbokor}

A következőkben egy olyan rímnégyesről lesz szó, amely nem futott be olyan nagy ívü karriert, mint az Imre Mihály által bemutatott nép-szép-kép-ép rímtoposz, ${ }^{413}$ vagy a Kovács Sándor Iván által ismertetett, szintén Rimaytól származó szelence-kemence-Velence rímtoposz, ${ }^{414}$ ám közvetett eredete talán szintén Rimayhoz vezethet vissza.

A Bónis Ferenc keserves énekeként ismert, Feketitett gyásszal beborult magyar nép... kezdetű éneket ${ }^{415}$ az akrosztichonja alapján a Wesselényi-féle összeesküvés után kivégzett Bónis Ferenc írta, a kolofonja alapján 1671-ben, a halála előtt két héttel. Már Imre Mihály monográfiája is felhívja a figyelmet Rimay rímtoposzának használatára, az első strófájának rímei ugyanis a következők: nép-ép-tép-kép.

A vers illeszkedik is ahhoz a tematikához, amelyben a rímbokor állandósul: Bónis Ferenc a hazájáért érzett aggodalmát énekli meg a családjától és hazájától búcsúzó énekben.

Az ének 28. strófája a következö:

A te igaz hited világ hitvány java,

El ne szakaszthassa töled hímes szava,

\footnotetext{
${ }^{411}$ RMKT 17/4. 79. sz. 191.

${ }^{412}$ RMKT 17/4. 154. sz. 318.

${ }^{413}$ IMRE, i.m. 239-274.

${ }^{414}$ KovÁcs Sándor Iván, Szelence - kemence - Velence, Egy Rimay-rímtoposz diadalmenete és bukása, Újhold évkönyv, 1988/1. 362-385.

${ }^{415}$ Kiadása: A kuruc küzdelmek költészete, kiad. VARGA Imre, Bp., 1977, Akadémiai, 18. sz, 51, 63.
} 
Sok kisértetekben legyen izes sava,

igy nem árt lelkednek pokol forró tava.

E négy rímből kettő, javát-szavát formában már Rimaynál is előfordult az Első címmel ellátott versében, ahogyan azt bemutattuk, és Thordai is használta e rímet az unitárius zsoltárokban. Rimay után Thordainál, majd utánuk egyetlen egyszer, Gyöngyösi Istvánnál találkozunk megváltoztatott ragos formában e rímmel: a Porábúl megéledett Fönix Elsö könyvének ötödik részében, a 49. versszakban.

Ne higgyen bizonyost akárki szavára,

Hogy bizott reménye forduljon javára. ${ }^{416}$

Gyöngyösi átvétele szintén szerelmes tematikánál jön elő, ám Bónis Ferenc énekében a hazához szóló strófák között található meg, immáron két újabb szóval, a sava és a tava rímekkel kiegészülve.

A rím ezek után ismét páros formában, most javát-savát formában, $\mathrm{s}$ Thordai zsoltárához hasonlóan az árvával egészül ki a rím Cserei Mihály 1691. március 19-ére szóló naptárversében. ${ }^{417}$

Nem közlötte velem világ semmi javát, sőt úgy tartott, mint egy elhagyatott árvát, sok keserüséggel nyeltem búknak savát, Isten tudom végre megszánja szolgáját.

A históriaíró Cserei Mihály azonban nem csak a két elemből álló rímet használja: a Zrínyi Ilona nevére írott heroidáiban (Eredj, siess, kérlek... és Isten hozzád, szívem...) már konkrétan egyezik a rím négy eleme azzal, amelyet Bónis Ferenc búcsúénekében találunk: ${ }^{418}$

Megadja az Isten magyar kívánt javát,

Noha most érzi inségeknek savát, Ám ússza csak által nyomorúság tavát, Meghallom gyönyörü szeretömnek szavát.

Látható, hogy a rímpár Rimay szerelmes költészetében fordul először elő, majd Thordai zsoltáraiban találkozhatunk vele. Ezután Gyöngyösi István Kemény Jánosról szóló heroidájában szintén szerelmes kontextusban fordul elő a rímpár, majd a zsoltárokat idéző hangvételü, a tavasz ellenére belső nyomorúságban szenvedő lírai ént megszólaltató Cserei-

\footnotetext{
${ }^{416}$ Internetes forrása: GYÖNGYÖSI István, Porábúl megéledett Fönix, avagy a néhai gyerömonsotori Kemény János erdélyi fejedelemnek Lónyai Anna asszonyal lévő házasságának...., kiadja JANKOVICS József, NYERGES Judit, Balassi Kiadó, é.n. http://www.balassikiado.hu/BB/netre/html/fonix/phonix.html Letöltve: 2015. 02.04.

${ }^{417}$ A teljes verset közli FERENCZI Zoltán, Cserei Mihály néhány ismeretlen verse1690-98-ból, ItK, 1891 /4, 437455.

${ }^{418}$ A szövegközlést és az adatokat $A$ magyar irodalom történetéböl vettük. TARNAI Andor, Nemesi költészet $=A$ magyar irodalom története, II, szerk. KLANICZAY Tibor, Bp., Akadémiai, 1964, 440-441.
} 
naptárversben fordul elő 1691-ben. Négyes rímként először Bónis Ferenc énekében 1671-ben találkozunk a szava-sava-java-tava rímmel, majd újfent Cserei Mihály használja fel a Zrínyi Ilona nevére írott heroidájában, melyben a haza és a szerelem is megjelenik.

A párrímekből kialakult bokorrím pályafutása addig könnyedén megmagyarázható, hogy Cserei Mihály feltehetően jól ismeri a korai kuruc darabokat is, Rimayt és Gyöngyösit is. Éppen ezért egy a „magasabb” irodalmi szinten lejátszódó átvételt feltételeznünk.

A rímek megjelennek viszont az 1697-es unitárius énekeskönyv egy olyan énekében is, amely a század elejétől kezdve tisztán unitárius környezetben hagyományozódik csupán. A tisztán unitárius forrásokban található énekanyagok szinte mindegyikének sajátja, hogy az egyes (kéziratos és nyomtatott) hordozókon alig mutatnak variabilitást. Az unitárius énekek maximum csak dogmatikailag változnak az egyes kiadásokban, másolatokban, a dogmatikai változás pedig általában azt a kérdést érinti, hogy Jézus Krisztus az Atyával egyenrangú, avagy az Atya által küldetett, kvázi alárendelt szerepben fordul elő. A Kérlek, keresztyén ember, hallgasd meg a jókat... kezdetü, csak unitárius forrásban megtalálható ének (RPHA 736) is mutatja ezt a tendenciát.

A kéziratos forrásai a következők: Bölöni-kódex és a Csonka antifonálé. Nyomtatott forrásai pedig az unitárius gyülekezeti énekeskönyvek: az 1602-15 közötti, az 1632-es és az 1697-es kolozsvári kiadások. Néhány apró toldalékbeli eltérést tartalmaz a Bölöni-kódex a többi variánshoz képest - ami már csak a földrajzi távolság miatt is érthető. Ezen kívül a dogmatikai összefoglalót tartalmazó záró strófa kerül csupán módosításra. Az 1602-15 közötti kiadás variánsában az első két sor a következő:

Dicsértessék Úristen a magas mennyekben,/ te áldott szent fiaddal, Krisztussal egyemben...

Ezt a variánst meghagyja a Csonka antifonálé is - melyről említettük, hogy igen gyakran követi az első unitárius gyülekezeti énekeskönyv variánsait ott is, ahol az 1632-es kiadás eltér attól. A Bölöni-kódex az Atya és a Fiú egyforma, egyenrangú tisztelését megváltoztatja, így a második sor a következő: te áldott szent fiadnak, Krisztusnak általa. A Krisztus által lesz tehát az Atya dicsérve. Az 1632-es kiadás az „egyemben”, azaz egyenlő mértékben kifejezést fogja csupán kicserélni arra, hogy az Atya és Krisztus mindenben dicsértessék, eltünik tehát az egyenlő mértékü tisztelet. Az 1697-es kiadás második sora újabb variánst közöl: te áldott szent fiaddal, Krisztussal az égben... lesz.

Ezen és a néhány, a Bölöni-kódex variánsában található toldalékváltozáson kívül azonban van egy olyan eltérés is az 1697-es kiadásban, amely az unitárius énekek szöveghagyományára nem jellemző. Az Úr által az embernek adatott jókat ismertető ének 10. 
versszakát az 1697-es kiadás ugyanis kicseréli egy új, de mondanivalójában gyakorlatilag teljesen azonos strófára. Ilyen eljárásmóddal az unitárius anyagon belül nem találkozunk másutt, maximum a dogmatikailag problémás strófák változtatásával.

A 10. versszak az 1602-15 körüli kiadásban, - s a többi forrásban is, az 1697-es kiadást kivéve - a következő:

Jó embernek beszéde, melynek vagyon haszna, másnak jó erkölcsére vagyon oktatása.

Ezekkel egyetemben öt vigasztalása, mint a jól fött éteknek vagyon ízi, haszna.

Az 1697-es kiadás 10. versszaka mondandójában ugyanaz, de poétikailag mégis csak jobban megszerkesztett:

Jó a bölcs embereknek is helyén mondott szava, melyben van tanúság, s jó tanácsnak sava, lelki vigasztalásnak fogyhatatlan tava, kiböl foly együgyüeknek üdvösséges java.

Az 1697-es unitárius énekeskönyv tehát felhasználja a Rimaynál és az ő nyomán Thordainál már félig meglévő, majd a Bónis Ferenc keservében, s annak nyomán Cserei Mihály szövegében kiteljesedő szava-sava-tava-java rímbokrot.

Ha most nem idézzük is fel a rímbokor előzményeit, annyira emlékezhetünk, hogy a személyes vallásosság kifejeződése mellett a hazától, a családtól búcsúzó korai kuruc kori darabból még témához is illeszkedően veszi majd át Cserei Mihály a raboskodó Zrínyi Ilona nevében írott verses levélbe a rímeket. Most viszont a tanítók munkájáról megemlékező strófában kap helyet a rím, egy tisztán unitárius forrású gyülekezeti énekben. A téma tehát megváltozik. Azt biztosan nem tudhatjuk, hogy miért kerül bele az 1697-es gyülekezeti énekeskönyvbe ez a strófa, ám talán valószínűsíthetjük, hogy Bónis Ferenc éneke, s nyomán a korai kuruc kori énekek igen népszerüek lehettek a közösségek körében. Így feltehetően a gyülekezet is ismerhette a darabot, darabokat, amelyekben a rímbokor mind a négy eleme elöfordult.

Noha az unitárius egyháznak, az unitáriusoknak nem volt közük sem a Wesselényiféle összeesküvéshez, sem a kuruc mozgalmakhoz, úgy tünik, a kuruc témájú szövegek népszerüek voltak unitárius körökben is. Ezt szemlélteti Csörsz Rumen Istvánnak a Gyözhetetlen én köszálam... incipitü ének variánsait tárgyaló tanulmánya, amely rávilágít arra, hogy egy eredetileg katolikus nagyheti, bűnbánó fohász bujdosó-énekké válása után 
elsősorban unitárius kéziratokban hagyományozódik tovább, az unitárius dogmatikai elveknek megfelelően. ${ }^{419}$

Az alapvetően a korai kuruc kori rímbokor unitárius gyülekezeti énekbe emelése arról tanúskodhat, hogy az unitáriusok már igen korán, a 17. század végén is jól ismerték ezeket a később egyértelműen nagy népszerüségnek örvendő darabokat, s felhasználták azok poétikai megoldásait.

\section{V.II. 6. Értelemváltozások a gyülekezeti énekben: rontások, javítások, módosítások}

A következőkben konkrétan a gyülekezeti énekek szövegeit érintő változás lesz a téma, részint olyanokról beszélünk, amelyek az énekek alapmondandóját nem befolyásolják, részint olyanokról, amelyek módosítják azt. Az ilyen jellegủ változások többsége illeszkedik a dolgozat elején tárgyalt, hálózatos kapcsolatként leírható nyomtatott énekeskönyvek közötti viszonyrendszerbe, ugyanis a szövegek változása, bizonyos sorok mondandójának rokon értelmü vagy tájnyelvi kifejezésekkel való kicserélése jól mutatja azt, hogy az egyes énekeskönyv-kiadások milyen viszonyban állnak egymással, illetve milyen önálló változási tendenciákat produkálnak. Mivel az unitárius szövegváltozatokban a dogmatikai jellegü változtatások a leggyakoribbak, ezekkel külön fejezetben foglalkozunk.

A hálózatos kapcsolódásról és a saját változásokról csak nagy vonalakban lehet beszélni, teljes körüen érvényes, kivételeket nem tartalmazó tendenciákat még e viszonylag kicsi korpusz esetében sem rajzolhatunk fel, mindig lesznek ugyanis éppen ellenkező irányba mutató példák is. Ezt talán éppen azzal magyarázhatjuk, hogy a konkrét kiadói/szerkesztői munkálatokon kívül az éneklés, az egyes gyülekezeteknél aktuálisan szokásban, hangzásban lévő variánsok is alakítanak a szövegeken. Megállapítható az is, hogy a kéziratos források sokkal több eltérést tartalmaznak, mint a nyomtatott énekgyüjtemények.

Nem általánosan és kivétel nélkül érvényes, de számos szöveg esetében megfigyelhető kapcsolat áll fönn például az 1569-es, 1570-es és az 1579-es debreceni református énekeskönyvek gyülekezeti énekeinek variánsai között. Minden kiadás tartalmaz saját eltérést is, ám ezek egyértelműen közel állnak egymáshoz. Az 1590-es debreceni kiadás sok esetben

${ }^{419}$ CsÖRSz Rumen István, Rákóczi halála nagypénteken - Mikestöl a közköltészetig = Író a számüzetésben: Mikes Kelemen, szerk. TÜSKÉs Gábor, munkatársak: CsÖRsz Rumen István, HEGEDÜs Béla, LENGYEL Réka, Bp., Universitas, 2012, 226-236 (Historia Litteraria 28). 
saját változásokat eszközöl a szövegeken, vagy visszanyúl az 1574-es komjáti és az 1582-es detrekői kiadások variánsaihoz, így ezekkel rokonítható szövegvariánsokat közöl. Az 1574-es komjáti és az 1582-es detrekői kiadások is sok esetben azonosak, s annak ellenére, hogy az 1560-as óvári, illetve az 1566-os váradi kiadással is rokoníthatók, mégis számos ponton különböznek azoktól. Újfalvi 1602-es debreceni énekeskönyve számos saját változtatás mellett a legtöbb ének esetében az 1590-es variánsokkal mutat rokonságot. Az 1590-es debreceni énekeskönyv több ének változatában is roppant mód hasonló az 1593-as bártfai evangélikus kiadáséhoz, ám ez utóbbi kiadás is tartalmaz saját változásokat, s emellett többször értelemrontó kifejezéseket is bevesz, ahogyan arra már céloztunk. Ezekkel szemben az 1602-14 közötti bártfai kiadás talán jelentősebb eltéréseket mutat fel, a leginkább eltérőek azonban az unitárius kiadások.

Azt gondolnánk, hogy a régi magyar versnek vannak olyan jegyei, amelyek a viszonylagos állandóságot hivatottak szolgálni, s valamilyen módon egy-egy ének azonosítójaként szolgálhatnak. Az akrosztichon mellett az incipit is ilyennek tünhet, föleg a gyülekezeti énekek esetében. Hiszen ha az alacsonyabb iskolázottságú, nem feltétlen deákos müveltségű hétköznapi hívő embernek a forgalomban lévő kétféle zsoltárszámozás valamelyike alapján kellett a több parafrázisban is terjesztett zsoltár valamelyikét beazonosítania, akkor nehezen tudta eldönteni, mit is kell valójában énekelnie. Az incipit megadása ennél jóval egyértelműbb helyzetet teremtett. A mindennapos gyakorlatban ezért nyilván ez alapján hivatkozhattak egy-egy énekre, ennek ellenére szembe tűnő, hogy az egyes kiadásokban, vagy egyes felekezeteknél (utóbbi esetben főleg az unitáriusoknál) gyakran már az incipit is eltér a többi kiadás szövegétől.

Ilyen, az incipitben is eltérést tartalmazó ének a gyülekezeti énekek közül az Int most minket Dávid próféta... kezdetű zsoltárparafrázis (RPHA 1417). Az ének az imént említett, az RPHA által is hivatkozott incipittel található meg a Detsi-kódexben és az 1590-es, illetve az 1602-es debreceni református kiadásokban. A további forrásokban az incipit eltér ettől: Unszol minket Dávid próféta... kezdettel találjuk az éneket a Bölöni-kódexben, a Csonka antifonáléban, az 1560-as óvári, az 1566-os váradi, az 1569-es és 1580-es debreceni, az 1574es komjáti, az 1579-es debreceni, az 1582-es detrekői, az 1593-as és az 1602-14 közötti bártfai, illetve az összes unitárius (1602-15 közötti, 1632, 1697) énekeskönyvben.

Az incipit eltérése apró jelentésbeli eltérés is egyben: Dávid intése helyett az unszolása inkább noszogatást, biztatást, kérlelést jelent. ${ }^{420}$

${ }^{420}$ Erdélyi magyar szótörténeti tár, XIII. kötet, SzABÓ T. Attila, Kolozsvár, EME, 2009, 772-73, unszolás szócikk. 
Az incipit alakváltozatában tér el az RPHA 963-as számú, Mikor a zsidó nemzet tartatnék Babilóniában... kezdetü ének. Az unitárius források (az 1602-15 közötti, az 1632es és az 1697-es gyülekezeti énekeskönyvek) a Mikoron zsidó nemzet... incipitet hozzák. Toldalékolásban tér el a Mint kívánkozik a szarvas a kútfejekhez... ${ }^{421}$ incipitü ének első sora: az 1560-as óvári, az 1570-es debreceni, az 1574-es komjáti és az 1582-es detrekői kiadásokban az első sor Mint kívánkozik a szarvas a kút fejéhez... lesz. Érdemes megemlíteni ennél a példánál, hogy noha a változás apró, de látható, hogy az 1569-es debreceni kiadás az egyik variánst, az 1570-es debreceni kiadás pedig - melyről úgy tartjuk, alig tartalmaz változtatást az 1569-es kiadáshoz képest, - a másik variánst hozza. Ez nem javító szándék eredménye, hiszen mind a kettő megoldás jó mind a rím, mind a ritmus szempontjából. Jól látható viszont, hogy a későbbi református kiadások az 1569-es változatot őrzik majd meg, az rögzül a debreceni énekhagyományban.

A Segítségül hívjuk a mennybéli Istent... (RPHA 1215) pont az imént vázolt debreceni eltérések ellenkezőjét mutatja: az 1569-es és az 1570-es debreceni kiadásokban toldalékváltozás figyelhető meg, ezáltal Segitséggel hívjuk a mennybéli Istent... lesz az incipit, ám a későbbi debreceni kiadások $(1590,1602)$ már az 1574-es komjáti és az 1582-es detrekői kiadásokéval egyező módon, Segitségül formában kezdik az éneket.

A Mire bánkódol, ó te, én szívem... (RPHA 999) kezdetű zsoltárparafrázis már nem csak az incipit eltérésére, hanem a metrikai változatoknál elmondottakra is példa. Az ének kissé eltér a gyülekezeti énekhagyomány többségétől a források tekintetében: megtalálható a Lipcsei-kódexben (S32/1), az 1590-es debreceni kiadásban, az 1612-es oppenheimi kiadásban, az 1602-15 közötti kolozsvári kiadásban, illetve ennek 1632-es bővített változatában, és az 1697-es unitárius kiadásban. Ez utóbbi kettő (az 1632-es és az 1697-es kiadás kivételével) minden forrás helytelen metrummal szerepelteti az ének kezdősorát a következő módon: Mire bánkódol, ó, én szívem...

Már csupán az incipitek változásából is látható, hogy a szövegváltozások nem teljesen konzekvens módon történnek (ld. a debreceni egymásból eredő kiadások eltéréseit). Arra, hogy e szövegváltozások, illetve maga a gyülekezeti énekhagyomány nem konzekvens módon változik, $\mathrm{s}$ emiatt tendenciákat bemutatni, releváns állításokat tenni igen nehézkes, jó példa a Szent Dávid próféta éneklö könyvének... kezdetü, talán legismertebb Sztárai-zsoltárparafrázis

\footnotetext{
${ }^{421}$ Ilyen formában található meg a Csonka antifonáléban és a következő nyomtatványokban: 1569 Debrecen, 1579 Debrecen, 1590 Debrecen, 1593 Bártfa, 1602 Debrecen, 1602-14 Bártfa, 1602-15 Kolozsvár, 1632 Kolozsvár, 1697 Kolozsvár.
} 
(RPHA 1309). ${ }^{422}$ Jelen fejezet elején szó volt arról, hogy a debreceni református nyomtatványok közül az 1590-es kiadás viszonylag sok új variánst közöl az előző debreceniekhez képest, s ennek egy része önálló változtatás, más része az evangélikus kiadások variánsaival rokonítható (1574 Komjáti és 1582 Detrekő), s arra is utaltunk, hogy az 1593-as bártfai evangélikus kiadás igen gyakran az 1590-es debreceni kiadás variánsaival mutat közösséget. Ennek ellenére ebben az énekben éppen az figyelhető meg, hogy noha az 1574-es komjáti és az 1582-es detrekői számos közös eltérést tartalmaz a többi kiadáshoz képest, ezekből az 1590-es debreceni nem merít. Ugyanígy megfigyelhető, hogy az 1593-as és az 1602-14-es bártfai kiadások nem az 1590-es debrecenivel mutatnak közös vonásokat, hanem variánsai több ponton az 1579-es debreceni kiadáséval egyeznek. Példa erre az ének 9. strófája, melyben az említett változási tendenciákon túl egy a csak unitárius forrásokban fellelhető változás is kimutatható. Látható, hogy a strófa értelme egyik kiadásban sem változik, ám a szórend megváltoztatásával, a toldalékok kicserélésével a sorok egészen más hangzásúak egy-egy variáns esetében. Úgy gondoljuk, az ilyen jellegű hagyományozódási kapcsolatoknak nem az az oka, hogy egy-egy énekeskönyv szerkesztője az összes addigi gyűjteményt maga elött tartva másolta, válogatta össze az új kiadás alapjául szolgáló anyagot, hanem az énekek ismerete, az aktuálisan a gyülekezetben élő variáns is rányomta bélyegét a nyomtatványokban szereplő énekek változatára.

A 9. versszak az 1632-es kolozsvári kiadásban a következö: ${ }^{423}$

Halandó testemnek ö gyarlóságától ${ }^{424}$ megszabaditasz ${ }^{425}$ engem, e világ sem árthat, sem álnokságával ${ }^{426}$, sem bosszújával nékem, ${ }^{427}$ mert csak ${ }^{428}$ teáltalad fö ellenségemet, az ördögöt meggyözöm, ${ }^{429}$ az én életemet csak tebenned bízván mindenkor helyheztetem. ${ }^{430}$

\footnotetext{
${ }^{422}$ A vizsgált források közül kéziratban megvan: Detsi-kódex, Bölöni-kódex, Csonka antifonálé. Nyomtatott forrásai: Komjáti, 1574; Debrecen, 1579; Detrekő, 1582; Debrecen, 1590; Bártfa, 1593; Debrecen, 1602; Bártfa, 1602-14; Kolozsvár, 1602-15; Kolozsvár, 1632 és Kolozsvár, 1697.

${ }^{423}$ Az 1602-15 közötti unitárius kiadásból hiányzik ez a strófa, ezért azt az 1632-es kiadás alapján vetettük össze a többi protestáns forrással. A következő lábjegyzetek az egyes variánsok eltéréseit tartalmazzák e kiadáshoz képest.

${ }^{424}$ halandóságától: Detsi-kódex, 1579 Debrecen, 1593 Bártfa, 1602-14 Bártfa.

425 megszabadítál: 1574 Komjáti, 1582 Detrekő.

${ }^{426}$ semmi álnoksággal: 1574 Komjáti, 1582 Detrekő.

427 és semmi bosszújával: 1579 Debrecen, 1593 Bártfa, 1602-14 Bártfa.

bosszúsággal énnekem: 1574 Komjáti, 1582 Detrekő.

428 én: Detsi-kódex, 1579 Debrecen, 1590 Debrecen, 1593 Bártfa, 1602-14 Bártfa, 1574 Komjáti, 1582 Detrekő, 1602 Debrecen.

${ }^{429}$ meggyőzém: 1579 Debrecen.

meggyőztem: 1574 Komjáti, 1582 Detrekő.

430 mikoron véghez viszem: 1574 Komjáti, 1582 Detrekő.
} 
Ennek az éneknek a 7. strófájának utolsó sora egyébként két, az imént felvázoltak alapján egymásból semmiképp nem eredeztethető variánsában is ugyanazt az értelemrontást tartalmazza:

Megvigasztalt ${ }^{431}$ engem te pásztori vessződ és te pásztori botod, a sok nyomorúság ${ }^{432}$, mellyel népedet ${ }^{433}$ megsújtod, sanyargatod, mellyel beszédedhez ${ }^{434}$ oly nagy szépen öket szoktatod és tanitod, hogy el ne vesszenek, söt veled legyenek mindörökké, akarod. ${ }^{435}$

Az 1579-es debreceni és az 1582-es detrekői kiadás rímel ugyan a többi sorral, de a toldalék miatt nem értelmezhető a strófa. E két forráson és az unitárius kiadásokon kívül minden forrásban helytelen a rím. Ezáltal mondhatjuk, hogy értelmében és rímképletében a leghelyesebb variáns az unitárius forrásokban található. Ritkán előforduló jelenség ez, hiszen ahogyan arra többször céloztunk, az unitárius források a leginkább eltérőek, s rím, ritmus, értelem szempontjából a legproblematikusabb variánsokat tartalmazzák.

A Hallgasd meg, Úristen, mi beszédünket ... kezdetü ének igen kevés forrásban jelenik meg (1566 Várad, 1582 Detrekő, 1602 Debrecen, 1602-15 Kolozsvár és 1632 Kolozsvár). ${ }^{436}$ Utolsó strófájának az 1602-es debreceni kiadás kivételével mindenütt azonos a lényegi mondandója: az Úristentől nem elég mindig csak kérni, szükség van arra, hogy erkölcsileg helyesen éljünk, illetve az Úr szavára hallgassunk, dicsérjük őt, s akkor fogja teljesíteni a szükségünk idején kérteket, a vershelyzetben a pogánytól való megszabadulást.

Azért felserkenjünk mi életünkben,
$n e^{437}$ csak kérjük Istent szüksségünkben,
de ${ }^{438}$ megjobbuljunk a mi erkölcsünkben, ${ }^{439}$
akaratját tehessük ${ }^{440}$ éltünkben, ${ }^{441}$
és dicsérjük Istent felségében, ${ }^{442}$
így hallgat meg minket szükségünkben. ${ }^{443}$

${ }^{431}$ megvigasztal: Bölöni-kódex, 1593 Bártfa, 1602-14 Bártfa, 1574 Komjáti, 1582 Detrekő.

${ }^{432}$ sanyarúság: Bölöni-kódex.

${ }^{433}$ népeidet: Bölöni-kódex, Csonka antifonálé, 1579 Debrecen, 1593 Bártfa, 1602-14 Bártfa. híveidet: Detsi-kódex, 1590 Debrecen, 1574 Komjáti, 1582 Detrekő, 1602 Debrecen.

434 te kezedhez: 1574 Komjáti, 1582 Detrekő.

${ }^{435}$ megtartod: Bölöni-kódex, Detsi-kódex, 1590 Debrecen, 1593 Bártfa, 1602-14 Bártfa, 1574 Komjáti, 1602 Debrecen. megmarad: 1579 Debrecen, 1582 Detrekö.

${ }^{436}$ A két 16. századi forrást összeveti PAP Balázs, i.m., 88-91.

437 és: 1602 Debrecen.

438 és: 1602 Debrecen.

439 életünkben: 1602 Debrecen.

${ }^{440}$ hallgassuk: 1566 Várad, 1582 Detrekő, 1602 Debrecen.

${ }^{441}$ életünkben: 1602 Debrecen.

${ }^{442}$ felségben: 1582 Detrekö. 
A lábjegyzetekből látható, hogy Újfalvi Imre énekeskönyve éppen arra buzdít, hogy kérjünk az Istentől ahelyett, hogy arra helyezné a hangsúlyt: ne csak kérjünk, dicsérjük is, s neki megfelelően éljünk. Két apró szó megváltoztatásával Újfalvi variánsa tulajdonképpen az ének értelmét változtatja meg: az állandó kérésen túli dicséretre serkentő ének így válik kérésre és dicséretre serkentő énekké. A 16. századból fennmaradt két variánst Pap Balázs összeveti, s az egész vers szövegében fellelhető különbségek alapján arra jut, hogy a „Váradi énekeskönyv e vers esetében ... nem lehet forrása a Bornemisza-kiadásnak..."444

Pap Balázs éppen ezért mind a két variánst Méliusz Péter (?) 1563-as, feltételezett debreceni énekeskönyv-kiadására vezeti vissza. Ha a két egymástól számos ponton eltérő forrás egy közös ősre vezethető vissza, s ez stemmával ábrázolható, akkor felmerül a kérdés, hogy a későbbi, (egymáshoz képest is, a korábbi variánsokhoz képest is) még több eltérést tartalmazó változatok honnan erednek? Itt is elveszett, mára nem ismert nyomtatványokat kell-e feltételeznünk, amelyekből további eltérő szövegváltozatok keletkeztek?

Úgy gondoljuk, az ilyen jellegü változások nagyszámú, tételes bemutatása adna arra lehetőséget, hogy árnyaltan mutassuk be a gyülekezeti ének legfontosabb sajátosságát, az elhangzásban és az énekeltségben való létezést. A nyomtatványok és a kéziratok ennek az élő hagyománynak a leképezései, amelyeket természetesen igyekeznek rögzíteni és állandósítani, de ennek során mégiscsak tekintettel kell lenni a gyülekezeti szokásokra.

Nem kizárt, hogy a Hálaadásunkban rólad emlékezünk... kezdetű ének (RPHA 478) 7. strófájának variánsai is elsősorban a hangzás alapján alakultak ki, hiszen egyazon felekezethez (és olykor városhoz) kapcsolható gyüjteményekben is különböző jelentésű, de hasonló hangzású szavak találhatók meg a strófákban:

Azért gyorsaságot elkezdett dolgunkban,
végig megmaradást mi hivatalunkban,
szorgalmatosságot hüséggel ${ }^{445}$ tisztünkben $^{446}$,
egymás szeretetét plántálj itt éltünkben. ${ }^{447}$

${ }^{443}$ kérésünkben: 1602 Debrecen.

${ }^{444}$ PAP, i.m., 91.

445 hívséget: 1560 Óvár, 1566 Várad, 1569 Debrecen, 1570 Debrecen, 1574 Komjáti, 1579 Debrecen, 1582 Detrekő, 1590 Debrecen, 1593 Bártfa, 1602 Debrecen.

hüséget: 1602-14 Bártfa.

${ }^{446}$ testünkben: 1566 Várad, 1569 Debrecen, 1579 Debrecen, 1582 Detrekő, 1590 Debrecen, 1593 Bártfa, 1602 14 Bártfa.

tétünkben: 1560 Óvár, 1570 Debrecen, 1574 Komjáti, 1602 Debrecen.

${ }^{447}$ életünkben: 1569 Debrecen, 1570 Debrecen, 1593 Bártfa, 1602-14 Bártfa. 
A testünkben-tisztünkben eltérés semmiképp nem lehet félreolvasás eredménye, a tisztünkben szót vagy $s z$-szel, vagy $z$-vel írják, míg a test szó nem fordul elő $z$-vel, $s z$-szel írva. Ezen kívül megfigyelhetö, hogy még a legtöbbször rokon variánst hordozó gyüjtemények is eltérő változatot hoznak, ilyen például az 1574-es komjáti és az 1582-es detrekői kiadás, vagy az 1590-es és az 1602-es debreceni. E példában olyan értelemmódosulással találkoztunk, amely alapvetően három, elsősorban a hangzósággal magyarázható variánst hoz létre.

A rím és ritmus változásainak bemutatásakor már szó esett arról, hogy úgy tűnik, olykor a későbbi nyomtatott kiadások hoznak ,jobb,” pontosabb, egy kvázi szerzői variánshoz közelebbi szövegváltozatot, semmint a korai protestáns énekeskönyvek. Feltehetően ugyanez figyelhető meg a szövegben bekövetkezett apró értelemmódosulás esetében is az Aki az Istent megismerheti... kezdetü ének 22-23. versszakában (RPHA 68). Az ének ezekben a strófákban és a következőkben sorra veszi, hogy kik (angyalok, fejedelmek, a község, az egyházi népek stb.) miért áldják és szolgálják az urat:

\section{Ti szent angyalok, Istent áldjátok, mert öáltala vagytok hatalmasok, mindenkor néki szavát halljátok, megfogadjátok, néki szolgáljatok. ${ }^{448}$ \\ 23.Ti fejedelmek meghallgassátok, ${ }^{449}$ Isten uratok, neki szolgáljatok, ${ }^{450}$ akaratában ti eljárjatok, mert tisztetekröl számot kell adnotok.}

A 22. versszak szolgáljatok kifejezése az 1560-as óvári kiadástól kezdve minden egyes forrásban ismétlődik a következő strófában: a fejedelmek is szolgáljanak az Úrnak. Az 1582es detrekői kiadás a kivétel ez alól: itt az „Isten uratok, őtet uraljátok” kifejezés egyrészt elkerüli a szóismétlést, másrészt a fejedelmekhez intézett strófában kellően hangsúlyozza, hogy Isten az úr, aki a fejedelmek számára is úr, felettük áll. Ám az, hogy szolgasága helyett azt hangsúlyozza, hogy a fejedelmek is uralkodójukként tiszteljék az Istent, sikerültebb sornak tűnik. Így nem kizárt, hogy Bornemisza szövegváltozata egy kevésbé széténekelt variáns, mint a korábbi vagy a későbbi kiadásokban találhatók. ${ }^{451}$

\footnotetext{
448 őneki szolgáltok: 1560 Óvár, 1569 Debrecen, 1574 Komjáti, 1602 Debrecen, Detsi-kódex, 1570 Debrecen, 1590 Debrecen, 1579 Debrecen.

őneki szolgáljatok: 1593 Bártfa, 1602-14 Bártfa.

449 ti is kik vagytok: Bölöni-kódex.

450 ötet uraljátok: 1582 Detrekő.

${ }^{451}$ Meg kell jegyeznünk azonban, hogy sem a Károli-féle, sem a Luther-féle Biblia zsoltára nem részletezi azt, hogy a fejedelmek vagy a prédikátorok hogyan, miként dicsérjék az Urat. Éppen ezért az összevetéshez a bibliai zsoltárokat nem tudjuk felhasználni.
} 
Ugyanebben az énekben az is megfigyelhető, hogy az egyházi személyek prédikálását a trombitához hasonlító strófában a hasonlat egyedül az unitárius variánsok esetében pontos, a többi változat 1560-tól kezdve kevéssé szemléletes. Az unitárius variáns szerint a strófa a következö:

\section{Egyházi népek, ti is kik vagytok, Istent áldjátok, mert pásztori vagytok, úgy kiáltsatok, prédikáljatok, mint egy trombita, ugyan harsogjatok. ${ }^{452}$}

A hangicsálás kifejezést jellemzően a kis énekesmadarakra használják, s ez a kifejezés az éneklés gyöngédebb, kedvesebb módosítása. Éppen ezért a prédikátorok meggyőző erejü prédikációját egy kis énekesmadár énekecskéjét idéző trombitához hasonlítani kevéssé tünik sikerültnek retorikai értelemben, mintha meghagyjuk a trombita harsogását. Úgy tünik, ebben az esetben is az egyik legkésőbbi kiadás hoz jobb formát a többinél retorikai értelemben. (Noha azt meg kell jegyeznünk, hogy a hangicsálás a zengedez szó szinonimája a TESZ szerint így a hangicsáló trombita, bár szókép szempontjából nem olyan jó, mint a harsogó trombita, ám mégiscsak jobban eszünkbe juttatja a gyülekezeti éneklés jellemzőit. Ld. Zengedezö mennyei kar.)

A Mint kívánkozik a szarvas... (RPHA 996) a 42. zsoltár parafrázisa, amely az akrosztichon alapján valószínűleg már romlott változatában (MIKLOS CHASEE) került be 1560-ban az óvári kiadással a nyomtatott gyülekezeti énekhagyományba. ${ }^{453} \mathrm{Az}$ ének viszonylag pontosan követi a zsoltár szövegét: Dávid a lelkéhez szól, de oly módon, hogy a narratív részben kiderüljön, az ének a számkivetése alatti bíztató zsoltár is egyben. A krisztianizált parafrázis párhuzamot teremt a zsidóság és a kereszténység között: az unitárius kiadások kivételével minden egyes szöveghagyományban úgy imádkozik Dávid, hogy az anyaszentegyházba vágyik vissza, az igaz szent keresztségre, illetve az ó törvényből jött új törvényről emlékezik meg.

A negyedik strófa csak az unitárius kiadásokban és a Csonka antifonáléban szerepelteti Jeruzsálemet, a többi forrás sok variánsban, de alapvetően Jeruzsálem helyett az anyaszentegyházat említve közli a strófát:

\footnotetext{
${ }^{452}$ úgy hangicsáljatok: 1560 Óvár, 1560 Várad, 1569 Debrecen, 1574 Komjáti, 1582 Detrekő, 1593 Bártfa, 1602 Debrecen, Detsi-kódex, 1570 Debrecen, 1579 Debrecen, 1590 Debrecen, 1602-14 Bártfa. úgy hangoskodjatok: Bölöni-kódex.

${ }^{453}$ Kéziratban: Csonka antifonálé. Nyomtatott forrásai a vizsgált források közül: 1560 Óvár; 1569 Debrecen; 1570 Debrecen; 1574 Komjáti; 1579 Debrecen; 1582 Detrekő; 1590 Debrecen; 1593 Bártfa; 1602 Debrecen; 1602-14 Bártfa; 1602-15 Kolozsvár; 1632 Kolozsvár; 1697 Kolozsvár.
} 
Lelkemnek $^{454}$ ezt megemlitvén, vetem sírásban,

mert én megyek csodálatos hajlékban,

a Jeruzsálembe, Istennek szent házába. ${ }^{455}$

A 8. strófában jól látható, hogy a Jordán földéről emlékező Dávid az unitárius variánsok esetében a számkivetés alatt emlékezik, a többi forrásban viszont az igaz keresztségről emlékezik meg:

Háborodott meg én lelkem én büneimben, azért ${ }^{456}$ emlékezem én most ezekröl ${ }^{457}$,

Jordánnak földéröl, én számkivetésemben. ${ }^{458}$

Ha az imént idézett strófa rímelését megnézzük, azt láthatjuk, hogy a rímelése a két variáns kontaminációjával lenne a többi strófában többé-kevésbé következetes aaa képletü, az alábbi módon: Háborodott meg én lelkem büneimben/azért róla emlékezem ezekben/ Jordánnak földéröl, én számkivetésemben.

A strófa második sorát tehát az unitárius forrásoké helyett a többi forrás alapján hoztuk, ám a rím így is csak akkor jön ki, ha Dávid zsoltárának parafrázisában a kereszténység helyett a számkivetés képe jelenik meg. A szöveg tartalmi elemein kívül a rím alapján is valószínűbb, hogy az unitárius variáns számkivetést említő sora lehetett a korábbi, a kvázi eredeti sor.

A következő, 9. strófa az unitárius források kivételével az ó és az új törvényre helyezi a hangsúlyt:

A szent alázatosságról, Hermon kis hegyröl,
Istennek házát óhajtom nagy messzül,
mélység hí mélységet, sok szentek beszédében. ${ }^{461}$

${ }^{454}$ lelkemet: 1569 Debrecen, 1570 Debrecen, 1574 Komjáti, 1579 Debrecen, 1582 Detrekő, 1590 Debrecen, 1593 Bártfa, 1602 Debrecen.

455 anyaszentegyházba, és Istennek házába: 1560 Óvár.

anyaszentegyházba, Istennek házában: 1569 Debrecen, 1570 Debrecen, 1579 Debrecen, 1590 Debrecen, 1593 Bártfa.

anyaszentegyházba, az Istennek házába: 1574 Komjáti, 1582 Detrekő.

anyaszentegyházba, Istennek szent házába: 1602-14 Bártfa.

anyaszentegyházba, istennek ő házába: 1602 Debrecen.

${ }_{456}$ azért róla: 1560 Óvár, 1569 Debrecen, 1570 Debrecen, 1574 Komjáti, 1579 Debrecen, 1582 Detrekő, 1590 Debrecen, 1593 Bártfa, 1602-14 Bártfa, 1602 Debrecen.

457 ezekben: 1560 Óvár, 1569 Debrecen, 1570 Debrecen, 1574 Komjáti, 1579 Debrecen, 1582 Detrekő, 1590 Debrecen, 1593 Bártfa, 1602-14 Bártfa, 1602 Debrecen.

${ }_{458}$ igaz szent keresztségről: 1560 Óvár, 1569 Debrecen, 1570 Debrecen, 1574 Komjáti, 1579 Debrecen, 1582 Detrekő, 1590 Debrecen, 1593 Bártfa, 1602-14 Bártfa, 1602 Debrecen.

459 az alázatosságról, és Hermon kis hegyéröl: 1560 Óvár, 1569 Debrecen, 1570 Debrecen, 1574 Komjáti, 1579 Debrecen, 1582 Detrekő, 1590 Debrecen, 1593 Bártfa, 1602-14 Bártfa, 1602 Debrecen.

${ }_{460}$ új törvény jöve nekünk ó törvényböl: 1560 Óvár, 1569 Debrecen, 1570 Debrecen, 1574 Komjáti, 1579 Debrecen, 1582 Detrekő, 1590 Debrecen, 1593 Bártfa, 1602-14 Bártfa, 1602 Debrecen. 
A krisztianizálásnak azzal a módjával gyakran találkozunk a zsoltárokban, hogy egyegy strófa utal Krisztus megváltó voltára, valamint az újszövetségre is. Arra azonban, hogy az alapvetően a zsidósággal, Dáviddal történt eseményeket úgy formálja át a narratív rész, hogy maga a beszélő, Dávid is keresztényként szólal meg, nincs több példa a vizsgált anyagban.

Ez a gyülekezeti ének tehát azáltal, hogy kontaminálja Dávid életének történéseit a kereszténységgel, szinte egy strófába tömöríti a korban oly népszerü zsidó-magyar történelmi párhuzamot. A kontamináció jegyében az énekben az egyes szám első személyű Dávid bárminemű bevezető strófa nélkül vigasztalja a lelkét az ellenség háborgatásakor. Ezáltal az éneklő hívek ugyanúgy egyes szám első személyben fognak a lelkükhöz beszélni, azonosulva Dáviddal. Talán ez a tömény, sűrített párhuzamosság tette lehetővé, hogy 1560-tól egészen az 1602-15 közötti kolozsvári kiadásig minden forrásban ilyen, kontaminált változatban él az ének, mely kontaminált változat feltehetően később keletkezett, mint a csupán az ószövetség dávidi hangján megszólaló variáns. A legtöbb gyülekezeti énekeskönyv tehát feláldozza a bibliai értelemhez való hűséget, ${ }^{462}$ s egy olyan változatot közöl, amely biblikus szempontból nem következetes, ám az éneklő hívek és Dávid sorsa között olyan nagyfokú közösséget teremt, amely során az éneklő hívek és szent Dávid hangja eggyé válik egészen az utolsó hivatkozó strófáig.

Ez a variáns a protestáns éneklésben évtizedeken át él, ami úgy gondoljuk, újabb bizonyítéka lehet annak, hogy a gyülekezeti énekgyüjtemények már a legelső kiadásokban is olyan szövegváltozatokat tartalmaztak, amelyek az éneklés során alakultak, igazodtak a közösségi igényekhez.

\section{II. 7. A bemutatott, a szöveget érintő változások összegzése}

Az előző fejezetben igyekeztünk kimutatni, hogy annak ellenére, hogy a gyülekezeti énekeskönyv-kiadások némelyike látható, rekonstruálható kapcsolatban áll más énekeskönyvekkel, mégis tartalmaznak az egyes kiadások variánsai olyan eltéréseket,

${ }^{461}$ beszédéből: 1560 Óvár, 1569 Debrecen, 1570 Debrecen, 1574 Komjáti, 1579 Debrecen, 1582 Detrekő, 1590 Debrecen, 1593 Bártfa, 1602-14 Bártfa, 1602 Debrecen.

${ }^{462}$ Természetesen sem a Károli-féle, sem a német Luther-féle bibliai zsoltárban nem található krisztianizáló elem. A Luther-féle zsoltár 7. szakasza például a következö: „,Mein Gott, betrübt ist meine Seele in mir, darum gedenke ich an dich aus dem Land am Jordan und Hermon, vom Berge Misar." 
amelyeket nem lehet magyarázni a szoros értelemben vett stemmával ábrázolható leszármazási ágrajzokkal. Úgy gondoljuk, e szövegváltozások okainak magyarázatához nem elég az elveszett és/vagy lappangó kéziratos és nyomtatott hagyomány feltételezése, hiszen néhol látható, hogy a gyülekezeti énekek mediális sajátosságai is rányomják bélyegüket a variánsokra. Úgy véljük, az énekeltségben, hangzóságban élés is befolyásolja az egyes variánsok létrejöttét.

Ezek a szövegváltozások nehezen értelmezhetők egy, minden protestáns forrásra egységesen érvényesnek mondható tendencia szerint. Az jól látszik, hogy az unitárius források szövegei a leginkább eltérőek, bár némely ének esetében más források is gyökeres változtatásokat mutatnak a megelőző forrásokhoz képest. Az is megfigyelhető, és viszonylag általánosnak mondható, hogy az egyéni kéziratos gyüjteményekbe is bekerülő szövegek esetében még erősebb variánsok keletkeztek, mint a csupán a nyomtatott hagyományba bekerülőknél.

E néhány példával igyekeztünk rávilágítani arra, hogy a gyülekezeti énekeskönyvek anyaga a látszólagos zártsága ellenére nyitott és fogékony a változásokra, elég, ha a korai kuruc korban kialakuló rímbokor gyülekezeti énekbe emelését említjük.

Számos szöveg esetében megfigyelhettük, hogy a 16. század magyar versének meghatározó jegyei (incipit, kolofon, akrosztichon, rímek) is igen gyakran másképp viselkednek a gyülekezeti énekgyüjtemények szövegei esetében, mint ahogyan arra számítanánk. Gyakran már eleve romlott akrosztichonnal kerülnek be az énekek az első nyomtatott kiadásba is, vagy éppen a részletező strófák kihagyásával. Ezek alapján úgy tűnik, még igen korán, a nyomtatott énekeskönyvek korszaka előtt variánsaiban kezdett élni a gyülekezeti ének, s ezek a variánsok azok, amelyeknek egyike-másika a nyomtatott hagyomány által rögzítésre kerül. Azt is láttuk, hogy a szerzőségre, szereztetésre utaló kolofon strófák a 16. század végére kezdenek eltünni, nincs már szükség rájuk.

Úgy tünik, a gyülekezeti énekgyüjteményekben rögzített szövegek többsége olyan variánsokat részesít előnyben, amelyekben a szereztetésre és a szerzőségre utaló jegyek eltünnek, s a szövegeik alkalmazkodnak a gyülekezeti, közösségi énekléshez, s a 16-17. század egyéni és/vagy közösségi éneklési igényeinek felelnek meg inkább. (Lásd a többes szám első személyre való átültetéseket vagy a keresztény Dávid-elbeszélő példáját).

Úgy tünik, a gyülekezeti énekek egy része már az első gyülekezeti énekeskönyvek megjelenésekor igen széténekelt, variálódott, változott szövegek voltak, amelyeken a szövegrögzítés talán egységesített, állandósított valamelyest, viszont a következő évtizedekben a felekezeti variánsok távolodtak egymástól. A közösségi éneklés mindenképp 
rányomja a bélyegét még a nyomtatott kiadásokra is, $\mathrm{s}$ a néhány példa talán rávilágított arra, hogy a gyülekezeti énekhagyomány vizsgálatakor nem tekinthetünk el az énekeltségtől, mint a szövegváltozások okának egyik fontos tényezőjétől.

\section{Dogmatikai eltérések az unitárius anyagban}

\section{1. A protestáns hagyomány dogmatikai változásai}

A dolgozat tárgya a gyülekezeti éneklés, így a vizsgált anyag minden darabja olyan, amely vagy zsoltár, vagy egyéb, a gyülekezet által közösen énekelt ének. Nem vettük bele a korpuszba az ünnepi énekeket, a kátéénekeket és a szertartáshoz szorosan kapcsolódó énekeket. Éppen emiatt a protestáns énekeskönyvek vizsgált szövegváltozatai között nem találunk akkora eltérést, hiszen a dogmatikai szempontból „kényes” kérdéseket a gyülekezeti énekek zsoltárai és egyéb énekei nem tárgyalják, hiszen az úrvacsora-tan, a szentségek kiszolgáltatása és egyéb, a protestáns egyházakon belül különböző dogmatikai szemléletet hordozó anyag nem ezekben, hanem a liturgikus énekekben jelenik meg elsősorban. ${ }^{463} \mathrm{~A}$ gyakran krisztianizált zsoltárok és a doxológiákkal ellátott gyülekezeti énekek így értelemszerüen az unitáriusoknál változnak a leginkább, az unitárius variánsokban találkozunk a legnagyobb mértékü dogmatikai eltéréssel.

A kolofonhasználatról szóló fejezetben már láthattuk, hogy az önreflexív, szerzői utalást tartalmazó kolofonstrófák szép lassan kikopnak a gyülekezeti énekekből, s a helyüket a záró strófaként alkalmazott doxológia veszi át. Erre példaként említettük az Aki az Istent megismerheti... (RPHA 68) kezdetű éneket, amelyből az 1560-as óvári kiadástól minden gyülekezeti énekeskönyvben meglévő kolofont az 1582-es detrekői kiadás már kiveszi, s a helyére doxológiát helyez. (Az 1602-es debreceni kiadás és az 1632-es unitárius kiadás más eljárást választ: a kolofont kiveszik, s a helyére - egymástól különböző, - a zsoltárszámra és Dávidra hivatkozó strófát közölnek.)

A doxológia így bizonyos helyzetekben a szerzésre utaló, a szerzőséget erősítő strófák helyettesítőjeként kerül be az énekek mögé. Ezeket az unitárius kiadások vagy elhagyják,

\footnotetext{
${ }^{463}$ Noha a 17. század végére a többi protestáns felekezet már olyan énekeskönyveket ad ki, amelyben a liturgia szerepe elhalványul, az unitáriusok még mindig olyan énekgyüjteményt adnak ki 1697-ben, amelyben a liturgia fontos szerepet kap. Mivel azonban a himnuszokat, antifónákat és egyéb, a szoros értelemben a liturgia rendjét meghatározó énekeket a dolgozatunk nem tárgyalja, így az okok vizsgálatától is eltekintünk.
} 
vagy jelentősen átalakítják. Az utolsó strófák kikopása - egyrészt a kolofonok elhagyása, másrészt a záró doxológia Szentháromságot dicsérő sorai miatt - kifejezetten az unitárius énekeskönyvek, énekgyüjtemények sajátjának mondhatók.

Bornemisza Péter énekeskönyvében a doxológiát a szövegek végére illesztő eljárás mellett azt is megfigyelhetjük, hogy az énekeskönyv-szerkesztő nagy hangsúlyt fektet a tanító jellegű megnyilatkozásokra is, olyan helyeken is, ahol az 1574-es komjáti kiadás még nem. ${ }^{464}$ Úgy tünik, hogy bizonyos szövegek esetében a korábbi gyülekezeti énekhagyományhoz képest Bornemisza szövegváltozataiban a Szentháromság-tan alapjai részletesebben, többször és hangsúlyozottabban jelennek meg, mint másutt. Erre a fent a doxológia kapcsán említett Aki az Istent megismerheti... (RPHA 68) is jó példa. A 15. versszak minden ${ }^{465}$ gyülekezeti énekeskönyvben - amely közli az éneket - az következőképp szerepel:

A mi testünkböl a lelkünk kimúlik,/ osztán e földre nem emlékezhetik,/ szent Dávid mondja, hinnie illik, / azért ${ }^{466}$ egy szent is nem imádkozhatik.

Tehát egy szent sem imádkozhat azért, hogy a földi életre a halál után emlékezzen, mondja a strófa.

Az 1582-es detrekői kiadásban az alábbi változatban található meg a strófa utolsó sora: azért szenteknek nem imádkozhatunk.

Bornemisza szövegváltozata, még ha az értelmet meg is változtatja, kihasználja az alkalmat arra, hogy egy tanító célzatú, a szentek tiszteletére vonatkozó mondatot helyezzen el a variánsában.

Bornemisza 1582-es detrekői énekeskönyvében van az egyetlen jelentős eltérés a többi protestáns változattól a gyülekezeti éneklés talán egyik legnépszerübb zsoltárának 2. strófájában is, az Erős várunk... kezdetüben (RPHA 392). A többi protestáns változathoz képest (... Ha kérded, hogy ki légyen az?/ Krisztus Jézus az,/ seregeknek Ura,/ kinél nincs több Isten, annál vagyon a gyözedelem) Bornemisza beveszi a strófába annak a nyomatékosítását, hogy az Atya és Jézus Krisztus egyformán tiszteltetik, egy személyben: Jézus Krisztus az,/ seregeknek Ura,/ ki Atyával egy Isten ... ${ }^{467}$

${ }^{464}$ Erről bővebben: OLÁH Szabolcs, Hitélmény és tanközlés, Bornemisza Péter gyülekezeti énekhasználata, Kossuth Kiadó, Debrecen, 2000 (Csokonai Könyvtár 22).

4651560 Óvár, 1566 Várad, 1569 Debrecen, 1574 Komjáti.

466 ezért: 1569 Debrecen.

467 A Luther-féle Biblia zsoltárában természetesen nem találunk semmiféle utalást Jézus Krisztusra, Luther zsoltárparafrázisban (Der 46. Psalm.; Ein feste Burg... 2. vsz.) pedig a kinél nincs több Isten-változat szerepel: Fragst du, wer der ist? Er heisst Jesus Christ, Der Herr Zebaoth, Und ist kein endrer Gott, Das Feld muss er behalten. Martin, LUTHER, Ausgewaelte Schriften predigten Tischreden Briefe und Lieder mit einem Vormort von Wilhelm Schaefer, Deutsche Buch-Gemeinschaft G.m.b.h. Berlin, o. J., 511-512. 
Bornemisza Péter 1582-es detrekői kiadása, e néhány példával szemléltetve talán mondható, hogy igyekszik az alapvető evangélikus dogmákat tanító jelleggel hangsúlyozni a gyülekezeti énekek szövegváltozataiban is, ahol csak lehet.

\section{2. Protestáns szöveghagyomány - unitárius dogmatikával}

Feltételezhető, hogy a dogmatikai eltérések a legtöbb esetben nem ,alulról,” a szövegeket használó gyülekezet kezdeményezésére rögzülnek, hanem fordítva: az egyházi vezetés, a szerkesztők által meghatározott mértékben és megfogalmazásban kerül be egy-egy változtatás a gyülekezeti énekhagyományba. Tehát ebben az esetben az említett mediális sajátosságok közül elsősorban a szerkesztők általi, a „felülről” történő változtatás lesz a meghatározó. Majd látni fogjuk, néhány esetben szinte értelmezhetetlen, hogy miért vesznek be egy-egy éneket az unitárius éneklésbe, mikor annak tartalmát, mondandóját szinte szóról szóra meg kell változtatniuk. Némi túlzással élve egyszerübb lenne kihagyni, vagy írni egy új éneket, a gyülekezeti énekeskönyvbe mégis bekerülnek. Talán az lehet az ok, hogy a protestáns felekezetek világában ismert szövegeket volt célszerü kiadni, hiszen így a más felekezetből érkezők a hagyományból ismert szövegekkel találkozhattak. Nem volt célszerü teljesen idegen szövegeket vinni a gyülekezet elé, hisz a különböző irányból betérő hívők az ismert dallamú és kezdősorú énekekkel otthonosabban érezhették magukat új felekezetükben.

Ennek rendkívül szemléletes példája az Atya Isten, tarts meg minket... kezdetü ének (RPHA 104), mely az 1602-15 közötti unitárius énekeskönyv elött gyakorlatilag minden általunk vizsgált gyülekezeti énekeskönyvben megtalálható, és a Szentháromság mindhárom személyét megszólító hálaadó ének. Az Atya Isten, tarts meg minket... az RPHA adatai alapján ${ }^{468}$ Martin Luther Ein Kinderlied címü énekének átdolgozása. A német nyelvü eredeti természetesen a Szentháromságra épít csakúgy, mint a német mintát követő többi magyar nyelvü protestáns variáns, így egyértelmü, hogy a következőkben bemutatandó unitárius szöveg az, amelyet néhány szó megváltoztatásával más értelmüre alakítanak.

Az 1574-es komjáti kiadásban és az 1582-es detrekőiben a címe a következő: Mégis más könyörgés az Szentháromságnak. ${ }^{469} \mathrm{Az}$ 1612-es oppenheimi kiadás pedig a

\footnotetext{
${ }^{468} \mathrm{http}: / /$ rpha.elte.hu/rpha/id/0104 Utolsó megtekintés: 2015. 09.21.

469 Az ének mintája tehát Luther Ein Kinderlied című éneke, mely tömörebb ugyan, mint a magyar nyelvü evangélikus variánsok, de a magyar nyelvü szövegek (ahogy majd látjuk, az unitárius változat kivételével)
} 
Szentháromság résznél közli az éneket. Az unitárius gyülekezeti énekeskönyvek mindhárom, a században ismert példánya beveszi az éneket. Ez a szövegváltozat erösen hasonlít Kossuth Lajos bicskájára: a Szentháromság három személyéből egyet, a Szentlelket kiveszi az unitárius variáns, Krisztust pedig megszólítja ugyanúgy, mint a többi variáns, de megváltoztatja azt a részt, ahol a Krisztus istenségéről esik szó, ezáltal hierarchikus viszonyban az Atya alá helyezi Jézus Krisztus személyét.

Egyébként az unitárius variáns ezt a szöveget az ellenség megtörésének kérésénél is megváltoztatja. Ahogyan arról szó volt már, az unitárius szövegek mindig „enyhítenek” ezeken a szöveghelyeken. Az első strófa unitárius változata a rontsd meg mi ellenséginket sor helyett, - mely a többi gyülekezeti énekeskönyvben többé-kevésbé azonos módon, de minden esetben a rontsd meg kifejezést használva szerepel - a következőt hozza: téritsd meg ellenséginket, és minden kegyetleneket.

A harmadik strófában a Krisztus mint király képet az unitárius variáns is megtartja, viszont az istenséget már elhagyja. A protestáns hagyomány harmadik versszaka a következő:

Krisztus, ki vagy Uraknak Ura,/ és császároknak császára,/ jelentsed istenségedet, és törd meg ellenségünket.

Ehhez képest az unitárius a szótagszámnak megfelelve változtatja meg dogmatikailag is az ellenségre kért csapást enyhítendő módon is a strófát:

Krisztus, ki vagy Uraknak Ura,/ és királyoknak királya,/ jelentsed te hatalmadat,/ téritsd meg ellenségedet.

alapvetöen - a pápa és a török aktualizált részeit kihagyva - követik a német eredeti gondolatmenetét. A német minta és a magyar változat bővebb, elemző összevetésére nincs mód, de a német szöveget nem tartjuk feleslegesnek közölni. Martin, LUTHER, Ausgewaelte Schriften predigten Tischreden Briefe und Lieder mit einem Vormort von Wilhelm Schaefer, Deutsche Buch-Gemeinschaft G.m.b.h. Berlin, o. J.

Ein Kinderlied,

zu singen wider die zwei Erzfeinde Christi und seiner heiligen Kirche, den Papst und Türken.

Erhalt uns, Herr, bei deinem Wort

Und steur des Papsts und Türken Mord,

Die Jesum Christum, deinen Sohn,

Wollten stürzen von deinem Thron.

Beweis dein Macht, Herr Jesu Christ,

Der du Herr aller Herren bist:

Beschirm dein arme Christenheit;

Dass sie dich lob in Ewigkeit.

Gott, heiliger Geist, du Tröster werth, Gieb dein'm Volk einrlei Sinn auf Erd,

Steh bei un sin der letzten Noth,

G'leit uns ins Leben aus dem Tod. 
$\mathrm{Az}$ isteni volta helyett az unitárius variánsban a Krisztus hatalma jelenik meg. A Szentlélek hasonló módon, ismét azonos szótagszámú szóval lesz „kiiktatva” a szentháromságból.

A többi protestáns variáns az első strófában az Úristenhez fordul (Atya Isten, tarts meg minket...), majd a harmadikban a Krisztushoz (Krisztus, ki vagy...), az ötödikben pedig a szentlélekhez (Ó, szentlélek áldott Isten...). Az unitárius viszont az 5. strófa első sorát megváltoztatja, ami által ismét az Istenhez fordul a beszélő: Ó, felséges áldott Isten...

$\mathrm{Az}$ unitárius variáns tehát néhány azonos szótagszámú szóval helyettesíti a dogmatikailag nem megengedhető elemeket, ezáltal a Szentháromságnak szóló könyörgést megváltoztatva egy alapvetően az Úristenhez, és (a nem istenségként szereplő) Krisztushoz szóló énekké alakítja át.

Arra, hogy ezt az éneket énekeljék, még ha a szövegen változtatni is kell, azért lehetett szükség, mert a protestáns hagyományban ismert, népszerű szöveget nyilván nem akarták elhagyni. Népszerüségét bizonyítja, hogy minden protestáns gyülekezeti énekeskönyv-kiadás tartalmazza, egyikből sem kopik ki.

Ugyanilyen apró, gyakorlatilag egy szavas változtatással kerül dogmatikai szempontból teljes átalakításra az Ó, mennyei nagy boldogság... kezdetű Szentháromság-ének is (RPHA 1123). ${ }^{470}$

A nem unitárius forrásokban minden esetben a Szentháromság-részben található a gyűjteményekben, s a vers az első versszakában a „mennyei nagy boldogságot” szólítja meg, melyről a negyedik versszak elején derül ki, hogy az a Szentháromság:

Uralkodó Szentháromság, /ki vagy élö hatalmasság,/földön, mennyen egy uraság. ${ }^{471}$

Az unitárius variáns a Szentháromságot mint megszólítottat lecseréli, s ezáltal az énekben végig meg nem nevezettként az Úristenhez fog szólni minden strófa:

Uralkodol irgalmasság,/ te vagy élö hatalmasság,/földön, mennyen egy igazság.

Látható, hogy ezekben az énekekben néhány szó azonos szótagszámú szóval való helyettesítése által teljesen megváltoztatható a dogmatika olyanra, amely az unitárius hitelveknek is megfelel.

A protestáns hagyományhoz képest általánosnak mondható az is, hogy az unitáriusok a Krisztussal, Krisztustól adatott Isteni dolgokat (üdvösség, kegyelem stb.) szinte mindig

${ }^{470}$ A szöveg a vizsgált források közül a következőkben van meg: Csonka antifonálé (S143); Bártfa, 1593 (RMNy 713); Bártfa 1602-14 (RMNy 965); Oppenheim, 1612 (RMNy 1037/2); és a három kolozsvári unitárius gyülekezeti énekeskönyvben: RMNy 983; RMNy 1541; RMK I, 1503.

${ }^{471}$ A szövegváltozat eltér az oppenheimi kiadásban és a bártfai evangélikusokban, most az átiratom az evangélikus kiadások variánsát hozza. 
megváltoztatják Krisztus által formulára. Ezzel az egyszerü, szinte tölteléknek tűnő szóval tulajdonképpen eléri az unitárius szövegvariáns, hogy hangsúlyozza: az Úristentől ered a megváltás, az üdvösség, a kegyelem, amelynek Krisztus „csak” a közvetítője, így nem is egyenrangú Istennel.

A dogmatikára összpontosító szövegvizsgálat során arra is figyelnünk kell, hogy a vizsgált korszakban az unitárius egyház nem rendelkezett egységes dogmatikai rendszerrel. Talán e dogmatikai sokszínűség vizsgálói számára is érdekes, hogy míg a kéziratos forrásokban vannak kifejezetten, erőteljesen hangsúlyozott nonadorantista jellegü énekek is, addig a nyomtatott hagyományban a 17 . század során általánosan vagy az adorantista, vagy az elkendőző, óvatosabb nonadorantista álláspont érvényesül. ${ }^{472}$ Feltűnő az is, hogy a protestáns hagyományból viszonylag kevés erősen krisztianizált zsoltár kerül az unitárius gyülekezeti énekanyagba, a saját, felekezeten belül keletkezett zsoltárok pedig (egyetlen kivétellel) egyáltalán nem krisztianizáltak.

A nyomtatott hagyományban található énekversek között vannak olyan szövegek, melyek tulajdonképpen átmenetet képeznek, kicsit „elkenik” a határozott álláspontokat, s Krisztus szerepe szempontjából különböző mértékű, minőségü tiszteletet jelenítenek meg a különböző szövegek. (Például nem ejtenek szót Krisztus istenségéről, viszont imádkoznak a Krisztus által az Atyához, vagy kérnek a Krisztus által az Atyától. Tehát Krisztus mint közbenjáró jelenik meg, az Atyai segítséget őáltala is lehet kérni ezekben a szövegekben. Vannak viszont olyan szövegrészek is, amelyekben egyáltalán nem jelenik meg ilyen hierarchikus viszony.)

Erre a Krisztus általi kérésre, könyörgésre, a közvetítő szerepre számos példát találunk a szövegek unitárius változatában, amelyek közül néhányat szemléltetünk. Az $O$, mely igen rövid volt, lám... kezdetü éneknek (RPHA 1121) a záró, doxológiát tartalmazó része a protestáns hagyományban az első nyomtatott megjelenésétől, (1569, Debrecen) kezdve a következőképp szerepel:

Mindezekre vezéreljen az Atya Isten,/ véle megváltó Fiúisten,/ a Szentlélek szentelö bizony Isten,/ Amen.

Az unitárius variánsban nincs szó a Szentlélekről, és a Fiúisten sem jelenik meg, aki a megváltó, hanem helyette az áll majd, hogy Krisztus által vezérelhet az Úristen bennünket a jóra, tehát Krisztus követendő példaként, esetleg közbenjáróként szerepel:

\footnotetext{
${ }^{472}$ Itt az olyan típusú megfigyelésekre gondolunk, hogy a kéziratos források gyakran „ember Jézus Krisztusról” beszélnek, míg a nyomtatványok a nonadorantista, de visszafogottabb „Krisztus által” formulákat részesítik elönybe.
} 
Mindezekre vezéreljen az Úristen,/ és ö vigyen ö szent ismeretiben,/ Fiának, Krisztus urunknak általa,/ Amen.

Az Unszol ${ }^{473}$ minket Dávid próféta... (RPHA 1417) erősen krisztianizált protestáns zsoltárszöveg. A zsoltárparafrázis - a Károli- és Luther-féle bibliai zsoltárral szemben ${ }^{474}$ - azt mutatja be, hogy az Úr irgalmassága Jézus Krisztussal válik megvalósulttá. Az unitárius szöveg, bár átveszi a krisztianizált zsoltárt, de végig, minden a Krisztustól kapott, Krisztusért az atyától kapott jóknak a felidézését Krisztus általra változtatja. Krisztus „,köztes,” közvetítő személyként jelenik tehát meg. Söt, figyelemre méltó az is, hogy ahol a zsoltár többi protestáns forrásában a sok kapott jóért Krisztus dicséretére buzdít a szöveg, ott az unitárius variáns változtatást hajt végre, és a jer, dicsérjük ezért őtet ${ }^{475}$ mi is örömmel sor helyébe a jer dicsérjük az Úristent mi is örömmel kerül. Így az unitárius hagyományban nemcsak a konkrét változtatásokat kell figyelnünk, hanem azt is, hogy mi az, amit elhagy, lecserél a szöveg, hiszen az is árulkodó lehet. A 15-16. versszak már nem is lesz az unitárius hagyomány része, mert ezekben olyan doxológia szerepel, amelyben Krisztus édes megváltóként szerepel, akinek az isteni volta hangsúlyos. Az unitárius nyomtatvány variánsa tehát egyértelműen nonadorantista.

A Dicsérd az Istent mostan... (RPHA 251) protestáns hagyományban található záró doxológiáját $^{476}$ az 1602-15 közötti és az 1697-es unitárius gyülekezeti énekeskönyv, illetve a Csonka antifonálé kihagyja. ${ }^{477}$ Szerepel viszont átalakítva, erős változatot hozva az 1632-es gyülekezeti énekeskönyvben. ${ }^{478}$ A Bölöni-kódex egy a Szentlelket a doxológiából kihagyó, de az 1632-es kiadáséhoz hasonló változatot hoz, melyet azonban egy másik kéz kihúz. ${ }^{479} \mathrm{~A}$ magánhasználatra szánt énekeskönyvekben is megvolt a szöveg, erröl tanúskodik az 1623-as énekeskönyv incipitjegyzéke, ${ }^{480}$ de az elveszett 1623-as kiadást, és a csupán makulatúrában fennmaradt 1635-ös kiadást nem tudjuk kézbe venni, így a szövegváltozatot csak az 1700-as magánhasználatra szánt énekeskönyvből ismerjük. Ebben viszont a gyülekezeti

\footnotetext{
${ }^{473}$ Int most: 1590 Debrecen; 1602 Debrecen; Detsi-kódex.

${ }^{474}$ A zsoltárparafrázis erősen krisztianizált volta természetesen nem jelenik meg egyik Biblia-fordításban sem, ez a parafrazeálás eredménye.

${ }^{475}$ Az előző strófa Krisztusról szólt, így az „őtet” rá vonatkozik.

${ }^{476}$ Uralkodol te azért, Uram Isten/ öröktöl fogva örökké mennyekben,/ a szentlélekkel egyetemben/ dicsérünk téged dicsöségedben.

${ }^{477}$ Érthető, hogy a kialakult szokást, miszerint az énekek végére záró doxológia kerül, az unitárius változatok általában nem tartják. Viszont mivel láttuk, hogy az unitáriusok a bibliai zsoltár értelmének megőrzésére nagy hangsúlyt fektetnek, így az sem kizárt, hogy ez is szerepet játszik a doxológia teljes elhagyásában, annak átalakítása helyett.

${ }^{478}$ Uralkodol te azért, Uram Isten,/szent fiaddal örökké mennyekben,/ ki megvigasztalsz szent lelkeddel,/ dicsérünk téged dicsöségedben.

${ }^{479}$ Uralkodol te azért, Uram Isten,/ te szent fiaddal örökké mennyekben,/ Krisztus Jézussal magasságban,/ dicsérünk téged dicsöségedben.

${ }^{480}$ VÁrfalvi NAGY János 1871, i.m.
} 
énekeskönyvek variánsához képest sokkal határozottabban nyomatékosított nonadorantista doxológiát ${ }^{481}$ találunk. Érdekes ez, hiszen csak a többi változat ismeretében tünik ki, egyébként nem tűnne fel, hiszen Jézust nem említi. Ismerve viszont a többi változatot, nagyon jól látható, hogy a kihagyásnak komoly oka van, a szöveg ezáltal még hangsúlyosabban radikálisabb dogmatikával bír, mint a korábbi, elkendőző, elkenő szövegváltozatot hozó változata.

Úgy tűnik tehát, hogy akár egy időben, egyazon gyülekezeten belül is - dogmatikai értelemben is - több változattal találkozhatunk. Ezek alapján arra következtethetünk, hogy a gyülekezeti éneklés során elsősorban az istentiszteletet tartó lelkész és a kántor álláspontjának megfelelő szövegváltozatban hangozhattak el ezek az énekek, hiszen az adorantistanonadorantista „skálának” több pontját is érintik a fennmaradt változataink.

Az unitárius korpuszon belüli különböző dogmatikai álláspont szemléltetésére jó példa a forrásoknál részletesebben bemutatott Bölöni-kódex is, ahol látható, hogy az 1615-től 1619ig, tehát a Keserüi Dajka János-féle vizitációig, illetve áttérítésekig a történeti dokumentumokból ismert állapotok uralkodtak. ${ }^{482}$ Azaz a kódexben olyan dogmatikával ellátott szövegek jelentek meg, amelyek többsége 1619-ig egy következetesen mérsékelt, adorantista álláspontot képviselt. Majd az áttérítések időszaka utáni szövegek radikálisabbak lesznek, mi több, a korábban a kódexbe másolt gyülekezeti énekeket is radikalizálja a másoló. A fenti példában a Bölöni-kódexben található záró strófa kihúzása is ennek a folyamatnak az eredménye lehet. Mi több, a példában azt is megfigyelhetjük, hogy a Bölöni-kódex később kihúzott záró strófája az 1632-es unitárius gyülekezeti énekeskönyvben található záró strófához hasonlít annak ellenére, hogy lejegyzése körülbelül 15 évvel korábban történt. Ez is alátámasztani látszik az elmondottakat, miszerint feltehető, hogy a gyülekezet lelkésze ezeket a szövegeket a saját dogmatikai álláspontjának a leginkább megfelelő változatokban énekeltette, illetve jegyeztette le. ${ }^{483}$

A Krisztus által Istenhez fohászkodást, mi több, a Krisztust az emberek számára követendő példaként bemutató alkotás a csak unitárius forrásban megtalálható Nagy hálákat az. Istennek adjunk... kezdetü ének. ${ }^{484} \mathrm{Ez}$ az ének az 1602-15 között kiadott unitárius

481 Uralkodol te azért Uram Isten,/ öröktöl fogva örökké mennyekben,/ ki megvigasztalsz szent lelkeddel,/ dicsérünk téged dicsöségedben.

${ }^{482}$ Molnár B. Lehel, A háromszéki unitáriusok 17. századi történetéhez. Toposz és valóság közt, Keresztény Magvető, 2012, 245-275. A Keserüi Dajka-féle meghallgatások anyagából ugyanis kiderül, hogy Háromszéken 1619-ig az unitáriusok és a reformátusok együtt tartották az istentiszteleteket, nem volt vita a felekezetek között. Erről bővebben a kódex ismertetésénél szóltunk.

${ }^{483}$ A Bölöni-kódex dogmatikai sajátosságairól részletesen nem ejtünk szót.

${ }^{484}$ Az első strófa az 1582-es detrekői kiadásban megtalálható Sok hálákat az Úristennek adjunk... kezdetű ének erősen megváltoztatott variánsa, de a többi versszak nem azonos ezzel. 
énekeskönyvben, és annak az 1632-es bővített változatában maradt ránk. Az első kiadásban a múltbeli hibákat soroló harmadik versszakban a szentségeket érintő kérdéskör nem jelenik meg, inkább értelmetlenné teszi ezt a részt, semmint a szentségek szolgáltatásáról beszéljen:

Az egy Istent mi hátrahagytuk volt,/ ö szent fiát nem is ismerjük volt, / az egy hitet mert lám sem értjük volt,/ szép jelekkel is nem jól éltünk volt.

Az 1632-es kiadás a némiképp értelmetlen szép jeleket javítja szent jelekre, több eltérés viszont nem figyelhető meg a két kiadás között. A Krisztus által az Istenhez fordulást szó szerint is hangoztatja a szöveg, a Krisztus és az Atya közötti hierarchikus viszonyt megjelenítve ezáltal a 9. strófában:

A Krisztusban kell nekünk vigadnunk, / ö általa kell Istent dicsérnünk...

Majd az ember és Krisztus között von párhuzamot az ének a 10. versszakban az alábbi módon:

Bizodalmunk nagy legyen Istenben, / mint szent fiát felvitte mennyekbe, / úgy minket is nem hagy itt e földön, Krisztus által felvészen mennyekbe.

A 12. strófa pedig a Krisztus és az ember között teremt hasonlóságot abból a szempontból, hogy az Istennek él Krisztus is, az ember is.

A Csak tebenned, Uram Isten... kezdetü ének (RPHA 222) záró strófájában nemcsak az 1602-15 között nyomtatott, hanem az 1632-es és az 1697-es unitárius kiadás is, a Csonka antifonálé is a többi protestáns forrásban szereplő szöveget hozza, nem ,általozik” Krisztussal kapcsolatban:

Ezt engedjed Atya Isten a te szent fiadért,/ a megváltó mi Urunkért, a Jézus Krisztusért, /kit bocsátál e világra halálra bününkért, lés megáldál mindörökké minket ö kedvéért.

Egyetlen (szintén unitárius) forrás tér el ettől, ez pedig az 1629 körül keletkezett Kassai István énekgyüjteményében található variáns. Ebben a Krisztus általi, de alapvetően az Úristennek köszönhető, emiatt hierarchiát állító dogmatikai álláspont fogalmazódik meg:

Ezt engedjed Atya Isten a te szent fiad által,/ a megváltó urunk által, Jézus Krisztus által,/ kit bocsátál e világra bününkért halálra,/ és megáldál mindörökké minket kedve által.

Kassai István énekgyüjteménye a kolozsvári unitárius felekezetben íródott, s

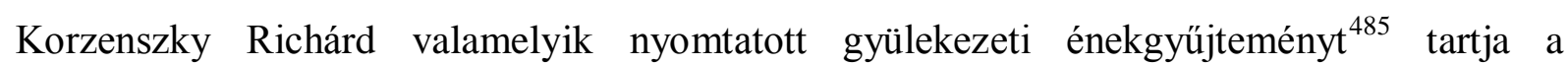

${ }^{485}$ KORZENSZKY Richárd, i.m. Korzenszky még több helyütt azzal magyarázza az eltéréseket, hogy elképzelhető, hogy a korábbi nyomtatott énekeskönyvből kerül ide az ilyen jellegü változtatásokat tartalmazó szövegek többsége. Mivel azonban ennek a korábbi nyomtatványnak a létezésére nincs bizonyítékunk, így a nagyszámú szövegváltozás miatt továbbra is úgy gondoljuk, hogy a Kassai István énekgyüjteményéhez hasonló gyüjtemények lejegyzése nem úgy történt, hogy egy másoló több forrásból szemezget, hogy a neki leginkább 
forrásának. Látható, hogy mégis eltér a nyomtatottaktól, ami alapján talán azt feltételezhetjük, hogy egy adott gyülekezeten belül is több változat élt, hiszen ekkoriban a gyülekezeten belül is viták dúltak a különböző dogmatikai álláspontok miatt.

Azt, hogy a későbbi kiadások dogmatikai szempontból nem „enyhülnek,” nem puhulnak az évtizedek során, már több példában is észrevehettük. Ilyennel találkozunk a Kérlek, keresztyén ember... kezdetü, szintén csak unitárius forrásokban megtalálható énekben is (RPHA 736). Ezt az éneket már a rímbokor miatt fentebb említettük, de érdekes, hogy az első kiadásnak az Atya és a Fiú egyenlő tiszteletét hangoztató strófáját éppen a későbbi kiadások fogják kihagyni, illetve megváltoztatni. Az 1602-15-ös kiadásban a záró strófa a következö:

Dicsértessék Úristen a magas mennyben,/te áldott fiaddal, Krisztussal egyemben,/angyali sokságnak fényes seregében,/földön lakó szenteknek gyülekezetében.

Az „egyemben,” egyenlő mértékben kifejezés a különböző kéziratos és nyomtatott forrásokban különbözőképp változik. (A Csonka antifonálé ugyanezt, az Atyát és a Fiút egyenlő mértékben tisztelő strófát hozza.) Az 1632-es gyülekezeti énekeskönyv a sort a te áldott fiaddal, Krisztussal mindenben-re változtatja, az 1697-es gyülekezeti énekeskönyv pedig a te áldott fiaddal, Krisztussal az égben-re. Az egyenlő mértékben való tisztelet hangsúlyozása az, ami a lecserélt szavakkal elmosódik. A Bölöni-kódex viszont az egész sort megváltoztatja, ezáltal hangsúlyozva azt, hogy a Krisztus által is dicsérve van az Úristen, erősebb, nyomatékosabb hierarchikus viszonyt állítva ezzel közöttük: Dicsértessél Úristen, a magas mennyben,/ a te áldott fiadnak, Krisztusnak általa.

Olyan példa is van azonban (Úrnak szolgái, no dicsérjétek... - RPHA 1447), amely éppen ellenkező eljárást mutat: az 1632-es és az 1697-es kiadás az Atya és a Fiú egyenlő mértékü tiszteletét hangoztatja, az 1602-15-ös kiadás is ugyanezt teszi, de másik, a többi protestáns forrással teljesen megegyező változattal. Ám más források „radikálisabbak:” a Csonka antifonálé és az 1700-as magánhasználatra szánt énekeskönyv az által-formulával él. Az 1602-15 közötti változat utolsó elötti strófáját idézve, a többi változatot lábjegyzetben szemléltetve ez a következö:

Miként öröktöl te dicsértettél felséges Úristen,/ most és mindenkor te szent fiaddal 486 áldassál, Úristen.

tetsző, leginkább alkalmas változatot írja le, hanem az általa ismert kéziratos vagy nyomtatott $E$ S orális hagyomány az, amely az ilyen jellegü gyüjteményekben kitapintható.

${ }^{486}$ ugyanez a forma: 1560, óvár; 1566 Várad; 1569 Debrecen; 1570 Debrecen; 1574 Komjáti; 1579 Debrecen; 1582 Detrekő; 1593 Bártfa; 1602 Debrecen. a te szent fiadban: 1632 Kolozsvár, 1697 Kolozsvár. 
Ebből, s az előző néhány példából nemcsak a dogmatikai tanúságokat vonhatjuk le, hanem azt is megfigyelhetjük, hogy a valamely nyomtatott forrásra visszavezetett kéziratok úgy tủnik, elsősorban nem a nyomtatott forrásból dolgoznak, hanem az aktuálisan a lejegyző által ismert változat kerül a kéziratba, amely nem egyezik pontosan a nyomtatvány szövegével. Az, hogy a nyomtatványokba olyan nagy mértékben nem kerülnek be nyíltan és erőteljesen radikális dogmatikai elemek, mint a kéziratokban, nyilván annak tudható be, hogy a nyomtatványok könnyebben ellenőrizhetők, könnyebben kerülnek más protestáns egyházak híveinek kezébe is, mint a kéziratos gyüjtemények. Ezen kívül érdemes hangsúlyozni azt is, hogy a nyomtatványokban gyakori, - példaként a Dicsérd az Istent mostan... (RPHA 251) unitárius variánsát hoztuk - hogy a radikális dogmatika elkendőzve, a kihagyás által jelenik meg. Így az, hogy a szövegváltozat radikálisabb a többinél, csak akkor vehető észre, ha ismerjük a többi variánst.

Az, hogy dogmatikai szempontból a században nem lesz egységes, jelentős radikalizálódás, sem jelentős enyhülés a nyomtatott szövegváltozatokban sem, azt mutatja, hogy a gyülekezet továbbra is különbözö, a dogmatika szempontjából nem feltétlenül egyforma és egyező nézőpontokat képvisel, de egy gyülekezetként éneklik, csak különböző formában az adott szövegeket. Úgy látszik tehát, a hatalmi vagy felsőbb nyomás hatására sem tűnt el az énekanyagból az a dogmatikai sokszínűség, amely az évszázad elején kimutatható volt.

A legfőbb bizonyíték erre talán az, hogy az Ó, te keresztyén ember... kezdetű, csak unitárius forrásban található, tízparancsolat-tanító ének, mely a pápa sötétségét ${ }^{487}$ eloszlató evangéliumnak örvend, majd az ember Jézus Krisztus szavait tolmácsolja. Krisztus emberi voltának a hangoztatása tehát az egész 17. századi unitárius nyomtatott és kéziratos énekhagyományban benne van.

Ezekből a példákból az látszik, hogy sem a dézsi complanatio, sem egyéb tiltások miatt sem nem enyhült, de nem is radikalizálódott a dogmatika a gyülekezeti énekeskönyvek szövegeiben, s nem is alakult ki egységes, minden unitárius gyülekezetre nézve érvényes egységes dogmatikai és teológiai szabályrendszer, illetőleg egy ezt képviselő énekhagyomány. ${ }^{488}$ A gyülekezeti énekek közösségi terjedését, a szövegek variálhatóságát

szent fiad által: 1700 Kolozsvár, Csonka antifonálé

${ }^{487}$ A pápa sötétsége szerepel az 1602-15-ös kiadásban, bár ez a szöveg nem a gyülekezeti énekeknél van. A Bölöni-kódex is ezt hozza. Az 1632-es és az 1697-es gyülekezeti énekeskönyv azonban szolidárisabb a pápával, ott az evangélium a lelki sötétség kioltója.

${ }^{488}$ A dolgozatnak nem tárgya az egyháztörténeti vonatkozások, zsinati határozatok és különböző rendeletek értelmezése, de úgy tünik, hogy az unitárius gyülekezeti énekhagyomány dogmatikájáról tett megfigyelések a legújabb kutatások fényében összhangban lehetnek az egyháztörténeti adatokkal is. Erről bővebben: MoLNÁR 
pedig az is jól bizonyítja, hogy a kéziratos hagyomány olykor minden ismert nyomtatott forrástól különböző, még eröteljesebben radikális dogmatikai álláspontot tükröző szövegváltozatot közöl annak ellenére, hogy látszólag a nyomtatott hagyományból dolgozik a lejegyző.

\section{A csak antitrinitárius forrásból ismert szövegekről}

A jelen fejezetben tárgyalt szövegek nagy többsége olyan, amelyeket csak unitárius nyomtatott és kéziratos forrásból ismerünk. Néhány szöveggel találkozhatunk egyéb protestáns kéziratos forrásokban is, illetve a Bogáti Fazakas-zsoltároknak a szombatos kéziratos hagyományban való tömeges, olykor a nyomtatottaknál jobb szövegváltozatokat hozó gyüjtemény-jellegü másolataival is számolnunk kell. A Bogáti Fazakas-zsoltárok szöveghagyományozódását éppen ezért nem tárgyaljuk, csak az unitárius énekhagyományban betöltött szerepükről beszélünk, hiszen ez az anyag merőben más forrásokban hagyományozódik, mint az általunk vizsgált verses szövegek nagy többsége. ${ }^{489}$

\section{1. Bogáti Fazakas-zsoltárok az unitárius hagyományban}

Bogáti Fazakas Miklós életéről, müveinek keletkezési idejéről és körülményeiről ugyanolyan hiányos adataink vannak csupán, mint a 16-17. századi unitárius egyház történetéröl, beleértve a bennünket foglalkoztató énekhagyományt is. Úgy tartják, hogy a 150 zsoltár fordítását 1582-83-ban készítette el, pécsi száműzetése idején. ${ }^{490}$ Bogáti zsoltárai kéziratosan terjedtek a 17. században, s csak néhány szövege került be gyülekezeti énekeskönyvbe. Legkorábban Újfalvi Imre 1602-es debreceni énekeskönyvében találkozunk

Dávid, „Scrabei per telas aranearum” A 17. század eleji erdélyi unitárius egyház eltussolt története? kéziratban.

${ }^{489}$ A szombatos hagyomány feltérképezése, bővebb tanulmányok születése a készülő kritikai kiadás után lehetséges. Mivel a szoros témánk a szombatos hagyomány nélkül is tárgyalható, így ezt nem részletezzük.

${ }^{490}$ Bogáti FAZAKas Miklós, Psalterium, Magyar zsoltár, Kit az üdökbeli históriák értelme szerént különbkülönb magyar ékes nótákra, az Isten gyülekezetinek javára fordított Bogáti Fazakas Miklós, a szöveget gondozta GILICZE Gábor, SZABó Géza, utószó DÁN Róbert, Magyar Helikon, 1979, 243. 
egy zsoltárával, s az 1602-15 közötti kolozsvári gyülekezeti énekeskönyv 12 szövegét emeli be a zsoltárok közé.

Jelen fejezetben az említett okok miatt csupán egy apró módosítást szeretnénk tenni a Bogátival kapcsolatos szakirodalom állításait illetően. Ez a nyomtatott unitárius gyülekezeti énekeskönyveket is érinti, így témánk szempontjából talán nem teljesen mellékes. Csomasz Tóth Kálmán a Thordai-zsoltárok keletkezésének okát abban látja, hogy a Bogáti Fazakaszsoltárokat a szombatosok kezdték el használni, így az unitáriusoknak szükségük volt új zsoltárfordításra, hogy a szombatos felekezettől való elkülönülésüket hangsúlyozzák. ${ }^{491}$ Mint azt a nótajelzések kapcsán kifejtettük, igen valószínünek tűnik, hogy Thordai a zsoltárait elsősorban a Szenci Molnár-féle zsoltárkönyv „francia dallamainak” idegensége miatt szerezhette, hiszen szinte minden zsoltára az unitárius énekhagyományban meglévő, a korban ismert nótajelzéssel van ellátva. Másfelől aligha hagyható figyelmen kívül, hogy a már említett Kövendi János-kódex (1697, S 105) a Thordai-zsoltárok mellett Bogáti Fazakas Mikós összes zsoltárát is tartalmazza, együtt is használták őket a 17. század végén. Az persze igaz, hogy Bogáti zsoltárai főleg a szombatos kéziratokban népszerüek, de a nyomtatott unitárius énekeskönyvben található Bogáti Fazakas-zsoltárok száma nem azt mutatja, hogy a népszerüsége jelentősen csökkenne a 17. század során a szombatosoktól való elkülönülés jegyében. Az 1602-15 közötti unitárius énekeskönyv 12 Bogáti Fazakas-zsoltárt tartalmaz. ${ }^{492}$ Ebből a 12 zsoltárból az 1632-es unitárius gyülekezeti énekeskönyv csak egyet nem közöl, a Kik Istennek csodáit láttuk... kezdetüt, bevesz viszont egy másik Bogáti Fazakas-zsoltárt, így számszerüen az 1632-es énekeskönyvben ugyanannyi Bogáti Fazakas-zsoltár lesz, mint az 1602-15 közötti nyomtatványban. ${ }^{493}$ Ennek a szövegnek a kikopása több okkal is magyarázható. Egyfelől azzal, hogy a metruma ${ }^{494}$ olyan, amely egyetlen 16. századi énekben sem fordul másutt elő, így feltehetően az éneklése sem volt egyszerü.

Az első strófáját idézve:

Kik Istennek csodáit láttuk,

kik e hadból és hazaszaladtunk,

\footnotetext{
${ }^{491}$ Magyarország zenetörténete II, 1541-1686, szerk. BÁRDOs Kornél, Bp., Akadémiai, 1990, 201-11.

${ }^{492}$ Ezt számszerüen írja az RMKT 17/4. is, a jegyzetekben, ld. 533.o. Az első unitárius énekeskönyv Bogáti Fazakas zsoltárai a következők: Kik Istennek csodáit láttuk... (RPHA 0753), Új Urat adtál, Uram... (RPHA 1414), Országa kárát... (RPHA 1159), A nagy bölcs teremtést... (RPHA 0027), Mely hatalmas a mi Urunk... (RPHA 0877), Egész Izraelt Dávid felgyüjté... (RPHA 0313), Istenem, tudod minden dolgomat... (RPHA 0606), Isten oltalmunk, erös kövárunk... (RPHA 0600), Neked mondok dicséretet... (RPHA 1063), Hogy e nagy pusztán lakunk... (RPHA 0544), Nemes földjét a szent népnek... (RPHA 1077), Hogy említjük eleinket... (RPHA 0547).

${ }^{493}$ A század eleji 12 Bogáti Fazakas-énekből hét még mindig kiadásra kerül az 1697-es század végi nyomtatványban is.

${ }^{494}$ a9 (4,5); a9 (4,5); a6; a17 (9,8); a $17(9,8)$.
} 
békével maradtunk,

jer az Urat dicsérjük még, és Úrnak hálát adjunk,

jertek minden vigasságtévő szerszámmal mind hangoskodjunk.

A kikopás egy újabb oka már az első strófa ismeretében is látható: a 95. zsoltár parafrázisának már az első strófája is olyan szöveggel van ellátva, mely az unitárius énekhagyománnyal ellentétes tartalmat közvetít, tehát az unitárius úzus és az ének tartalmi elemei nem összeegyeztethetők.

Többször említettük, hogy az unitárius kiadások (már az első kiadás is, de főleg az 1632-es) igyekeznek a protestáns hagyományból kivenni, megváltoztatni, „enyhíteni” az ellenség megtöréséröl, leveréséről, a harcokról szóló tartalmakat, s ez a zsoltár - már a bevezetőstrófa alapján is látható, hogy - a harcból hazatérők, „hazaszaladók” hálaéneke az Úrhoz.

Az első strófában a „,vigasságtévő” szerszámokkal való hangoskodás is szerepel, s bár az unitárius éneklésről igen kevés adatunk maradt fenn, de a különböző dokumentumok fényében talán mondhatjuk, hogy az unitárius éneklésben a hangszeres zene nem játszott szerepet.

Enyedi György 1597 elötti, az éneklésről szóló prédikációja kifejezetten rávilágít arra, hogy a „pápások tévelygése” csupán az „éneklésben, hogy sípokat, orgonákat fúnak a templomban." 495 Enyedi kitér arra, hogy - bár az Ószövetség zsoltárai gyakran tartalmaznak hangszeres zenét - ezt az Újszövetség már nem tartalmazza, így az ilyen eszközök használata besorolódik a zsidókat e tekintetben szolgaian követő pápisták téveszméi közé, hiszen mára „az orgonálás, sípolás annyira ment, hogy csak testi gyönyörüségekért lészen a pápások közt." "496 Így Enyedi az unitáriusok éneklése kapcsán arra jut, hogy „,mi azért elégedjünk meg a szájjal és szóval mondott dicséretekkel, és eképpen magasztaljuk a mi Istenünket."

Enyedi prédikációja a nyomtatott énekeskönyvek megjelenésénél ugyan korábbi, de néhány szórványos adat az éneklésről a 17. század első harmadából is fennmaradt. Tóth György könyve 498 alapján úgy tünik, hogy a 17 . század első harmadában is a hangszeres kíséret nélküli éneklés volt a bevett szokás az unitárius gyülekezetekben, az Enyedi által megfogalmazott hangszerhasználat-mellőzés feltehetően általános érvényü volt. 1614-ből maradt fenn egy rendelkezés, mely a gyermekek templomi énekléséröl szól, tehát kórus

\footnotetext{
${ }^{495}$ H. HUBERT szövegközlésében, i.m., 388.

${ }^{496}$ H. HUBERT, i.m., 389.

${ }^{497}$ H. HUBERT, i.m., 389.

498 Tóth György, Az unitárius egyház rendszabályai (1626-1850), Kolozsvár, 1922.
} 
biztosan volt ebben az időszakban: „,[A]z iskolamesterek ...az alamizsnából három vagy legkevesebb két gyermeket tápláljanak és neveljenek, hogy velük a templomban énekelhessenek, amit ha tenni elmulasztanak s az alamizsnát mégis begyüjtenék, a szokásos büntetéssel sújtassanak. "499

1629-ből fennmaradt egy utasítás az egyházi rendszabályokban, miszerint „,ha lehetségesnek látszik, hogy a hangszeres zene - mely többnyire inkább visszaélés, mint szokás - a menyegzök és egyéb vendégeskedések alkalmából kiküszöböltessék... "500 Úgy tűnik tehát, hogy még a menyegzökön, tehát a nem csupán az egyházban, templomban történő események során sem preferálta az egyházi vezetés a hangszeres zenét, ezért joggal következtethetünk arra, hogy az istentiszteletek alatt még kevésbé pártolták azt.

A hangszeres templomi énekléssel kapcsolatosan az is adat lehet számunkra, ha nincs adat. Molnár Dávid hívta fel a figyelmemet arra, hogy a templomviták során az általa vizsgált időszakban, a 17. század első felében sehol nem maradt fönn olyan regestrum vagy bármiféle jegyzőkönyv, említés, amely az unitáriusok templomban használt hangszeréről tanúskodna, holott a templomok értékes tárgyait, berendezéseit felsorolják. ${ }^{501}$

Valószínűleg az 1629-es, a „hangoskodó, szerszámos éneklést” tiltó rendelet lehet az oka annak, hogy a Thordai által szerkesztett 1632-es gyülekezeti énekeskönyvből kiveszik a Kik Istennek csodáit láttuk... kezdetű Bogáti-zsoltárt.

Az unitárius hagyományban a legnépszerübb Bogáti Fazakas-zsoltár egyébként az Egész Izraelt... kezdetű, mely az általunk vizsgált szinte összes unitárius kéziratos és nyomtatott gyüjteményben megvan. ${ }^{502}$

Az 1632-es gyülekezeti énekeskönyv 12 Bogáti Fazakas-zsoltára nem tanúskodik Bogáti Fazakas Miklós népszerüségveszéséről. Sőt, hozzátehetjük, hogy az 1632-es gyülekezeti énekeskönyvben 7 Thordai-zsoltár van összesen, tehát kevesebb, mint Bogáti Fazakas.

\footnotetext{
499 TóTH György, i.m., 30.

${ }^{500}$ TóTH György, i.m., 37.

${ }^{501}$ Köszönettel tartozom Molnár Dávidnak az adatokért, amelyeket szóban megosztott velem. A templomvitákról szóló tanulmánya: MoLnÁR Dávid, Református-unitárius templomviták (1615-1648), Keresztény Magvető, 2014/1. 3-21.

${ }^{502}$ Az összes 17. századi nyomtatott gyülekezeti és magánhasználatra szánt énekeskönyvben (még az 1700-asban is), illetve a Bölöni-kódexben és a Csonka antifonáléban is megtalálható.
} 


\section{2. Lengyel zsoltárfordítások az unitárius hagyományban: néhány apró kiegészítés}

A csak unitárius forrásokban megtalálható hat Kochanowski-fordítást és négy másik lengyel dallammintát használó zsoltárt az RMKT 17/4. közli, és Papp Géza tanulmánya ${ }^{503}$ részletesen összeveti a lengyel eredetivel a fordítások szövegét, meggyőzően bizonyítva azt, hogy ezek az unitárius forrásban található zsoltárok vagy a lengyel költő, Jan Kochanowski zsoltárainak fordításai, illetve átdolgozásai, vagy lengyel zsoltárra vezethetők vissza. ${ }^{504}$

Az erdélyi és a lengyel unitáriusok érintkezéséről, kapcsolatairól az utóbbi időben egyre több anyag került napvilágra. ${ }^{505}$ Tudjuk, hogy a 16. század közepe-végén és a 17. század elején is élénk kapcsolat volt a felekezet erdélyi és lengyelországi képviselői között. Igen homályos, ma már aligha igazolható adat konkrétan az énekeskönyvek lengyel kapcsolatáról is maradt fönn: az egyháztörténet említi, hogy az első, Dávid Ferenc idejében kinyomtatott unitárius énekeskönyv (mely feltehetően soha nem jelent meg, s ilyenről nincs tudomásunk a mai napig) a lengyel zsoltárkönyvekből is dolgozott. ${ }^{506}$ Ezt az adatot átveszi mindenki, aki az unitárius énekeskönyvekről ír, ám ennek relevanciája Papp Géza Kochanowski-fordításokról írott tanulmányában ${ }^{507}$ van igazán, hiszen ő mutatja be tényszerüen, hogy mely lengyel zsoltárok szövegeiből, mely lengyel dallamokra íródott a szóban forgó 10, az unitárius énekeskönyvben található zsoltár. A Papp Géza által elemzett 10 magyar nyelvű zsoltárból hat Kochanowski-fordítás, négy pedig olyan lengyel dallammal ellátott szöveg, amely a lengyel zsoltárkönyv dallamaiból merített.

Azt, hogy ki fordíthatta le a lengyel zsoltárokat, sajnos nem tudjuk rekonstruálni, ám az nagyon valószínü, hogy ezek a zsoltárfordítások nem Dávid Ferenc idejében jelentek meg,

\footnotetext{
${ }^{503}$ PAPP Géza, Ismeretlen Kochanowski-forditások a XVI.-XVII. századból, ItK, 1961, 328-340.

${ }^{504}$ A Papp Géza által tárgyalt, és az $R M K T$ 17/4. által kritikai kiadást hozó (8-17. sz. alatt) lengyel zsoltárok fordításai a következők: Isten kegyes füled szómat...; Jaj meddig, nagy Úristen ...; Ím, s hogy kiält... ; Ó, nagy Úristen...; Kitisztitván Absolonnak...; Istenben bizván...; Bünnek/bünök soksága...; Egész Izraelnek népe...; Bánatában Dávid...; Reménységem vagy, Istenem....

${ }^{505}$ Ide sorolhatjuk Keserú Gizella tanulmányát, mely a 17. század eleji lengyel-magyar kapcsolatokat mutatja be, és Balázs Mihály tanulmányát, mely az elhúzódó felekezetiesedés szempontjából ismertet fontos adatokat. KESERÜ Gizella, Az erdélyi unitárius egyház megkésett konfesszionalizálódása és a lengyel testvérek a 17. század elején = „Nem sülyed az emberiség!” Album amicorum Szörényi László LX. születésnapjára, föszerk. JANKOVICS József, MTA ITI, Bp., 2007, 429-449. http://www.iti.mta.hu/Szorenyi60/Keseru_Gizella.pdf Letöltve: 2015. 03.09. BALÁzs Mihály, Elhúzódó felekezetiesedés és rendhagyó kátéirodalom (Az unitáriusok kátéiról a kezdetektöl a dézsi komplanációig) = Felekezetiség és fikció, Régi Magyar Könyvtár Tanulmányok 8, Bp., Balassi, 2006. 37-75.

${ }^{506}$ KÉNOSI-UzONI, i.m., 796. A Dávid Ferenc korában kiadott énekeskönyvet tartja első kiadásnak szinte minden, a 19. században keletkezett unitárius énekeskönyvekről szóló szakirodalom is, pl.: JAKAB Elek, Adatok énekeskönyveink bibliographiájához, MKSz, 1882 40-71. és KANYARÓ Ferenc, A legrégibb unitárius énekeskönyvekröl, MKSz, 1895, 321-332.

${ }^{507}$ PAPP Géza, i.m., ItK, 1961, 328-340.
} 
ha megjelentek egyáltalán az 1602-15 között nyomtatott énekeskönyv előtt nyomtatásban. Ki kell viszont emelni, hogy Papp Géza is azon az állásponton áll, hogy a zsoltárokat már az előző kiadás is használta ${ }^{508}$ - bár Papp nem mondja, hogy ez a nyomtatvány Dávid Ferenc idejéből való, de az általa hivatkozott szakirodalom ${ }^{509}$ azt állítja.

Papp Géza viszont az idézett két tanulmányában arra is kitér, hogy Jan Kochanowski zsoltárai Psalterz Dawidów címmel 1579-ben jelennek meg először Krakkóban, amikor még nincs melléjük dallam, mert az csak egy évvel utána kerül hozzájuk. ${ }^{510}$ Abban Papp Géza sem foglal egyértelmủen állást, hogy a magyar fordító pontosan mely forrást használta, (ahogyan írja, 1579 után mindjárt, 1580-ban újrakiadásra került a lengyel zsoltárkönyv, már dallammal ellátva) de azt sugallja, hogy a magyar fordító feltehetően az orális hagyományon alapuló dallamokat ismerhette, nem a zsoltárkönyv valamely utólag a zsoltárokhoz társított dallamait. ${ }^{511}$ Azóta úgy tudjuk, hogy az unitárius anyagban megjelenő hat Kochanowskizsoltár és a másik négy zsoltár is megtalálható volt Piotr Artomiusz Krzesichleb Cantionnal albo pies'ni duchowne címü, igen népszerü énekgyüjteményében. ${ }^{512}$ Ezt használhatta tehát a magyar fordító, nem a Kochanowski-zsoltárkönyvet. Ez az énekgyüjtemény először 1587ben, Dávid Ferenc halála után (1579) jópár évvel jelent meg. Éppen ezért azt a feltételezést, hogy Dávid Ferenc idejében jelent meg olyan magyar nyelvü unitárius énekeskönyv, mely tartalmazta a lengyel fordításokat, egyértelmúen el kell vetnünk.

\footnotetext{
508 „Ismeretes, hogy a legrégibb, ma már nyoma veszett unitárius énekeskönyvünkhöz többek között a lengyel unitáriusok zsoltároskönyvét is felhasználták. Erröl nem csupán Uzoni Fosztó kéziratos egyháztörténetének közel egykorú kiadása tanúskodik, hanem az énekeskönyv késöbbi, XVII. századi (1607, 1627 u., 1697) kiadásaiban található tíz ének „Nota Pol(onica)” felirata is. Ezeknek az énekeknek eredetét - egy kivételével - sikerült is kimutatni, s dallamukat megállapítani.” PAPP Géza, i.m., ItK, 1966, 208.

509 Csomasz Tóth Kálmán, Régi Magyar Dallamok Tára I, A XVI. század magyar dallamai, Bp., Akadémiai, 1958, 102.

${ }^{510}$ PAPP Géza, i.m., ItK, 1961, 338. és PAPP Géza, i.m., 1966, 209.

${ }^{511}$ PAPp Géza, i.m., ItK, 1961, 338. és PAPP Géza, i.m., 1966, 209.

512 HopP Lajos - Jan SLASKI, A magyar-lengyel múltszemlélet elözményei, (Politikai és kulturális hagyományok Báthory Istvánig), Bp., Tankönyvkiadó, 1992, 187. Bár Balázs Mihály tanulmánya kitér arra, hogy Kochanowski zsoltárainak egyharmada 1571-re már készen volt, és ezek kéziratosan terjedtek el a lengyelek körében, de nem tudjuk pontosan, hogy ezek mely zsoltárok voltak, s arról sincs adatunk, hogy ezek eljutottak volna Erdélybe. BALÁzS Mihály, Jan Kochanowski és Balassi Bálint, Tiszatáj, 2012, 135, 12.
} 


\section{2. 1. A lengyel zsoltárfordítások helye az 1602-15 között nyomtatott unitárius énekeskönyvben}

A lengyel zsoltárfordítások előfordulási helye az 1602-15-ös unitárius énekeskönyvben rokonítható a Bogáti Fazakas-zsoltárok előfordulási helyével. Említettük, hogy az 1602-15 közötti énekeskönyvben a zsoltárok még a debreceni énekeskönyvhagyományban megszokott rendet követik, és a zsoltárok száma szerint növekvő sorrendben találhatók meg a gyüjteményben. Ha az itt előforduló zsoltárokat összevetjük az Újfalvi Imre 1602-es kiadásában közölt zsoltárokkal, meglepő, - bár mint mindig, itt sem kizárólagos érvényü, ám mégis - tendencia-szerüen érvényesülő mozzanatokat mutathatunk ki.

Újfalvi Imre a zsoltárok között összesen 18 Sztárai Mihály által írott parafrázist közöl, ebből 4 olyan, amelyet Sztárainak tulajdonítanak, de a szerzőség kérdése nem tisztázott. ${ }^{513}$ Ebből, az összesen 18 Sztárai-zsoltárból az unitárius énekeskönyv zsoltárrészében kettőt találunk, melyet bizonyosan ő szerzett, és kettőt, amely bizonytalan szerzőségü, csak Sztárainak tulajdonított. Ezek a Sokan vannak most... (RPHA 1283) ${ }^{514}$ és a Szent Dávid próféta... (RPHA 1308), ${ }^{515}$ illetve a bizonytalan szerzőségűek közül az Izraelnek megnyomorodott... (RPHA 627) és a Drága dolog az Úristent... (RPHA 291) incipitü zsoltárok. 18 Sztáraiból tehát 4 van összesen az unitárius zsoltárrészben az 1602-15-ös kiadásban. ${ }^{516}$

Feltünő, hogy a 44. zsoltárig ${ }^{517}$ Újfalvi református énekeskönyve 11 Sztárai zsoltárt közöl, az unitárius viszont csak kettőt. (A Sokan vannak most... és a Szent Dávid próféta... kezdetűeket.) A 12. zsoltárnak Újfalvi énekeskönyve három parafrázisát is hozza, az $O$, Úristen, tekints hozzánk...(RPHA 1139), az Emlékezzél meg, Úristen... (RPHA 365) és Sztárainak a Szabadits meg és tarts meg, Uram, Isten... (RPHA 1295) kezdetűeket. Ebből a kolozsvári unitárius kiadás az első kettőt közli, de a Sztárait már nem.

\footnotetext{
513 Az Újfalvi szerkesztette énekeskönyv anyagát rendszerezte: Ács Pál kísérőtanulmánya, Újfalvi Imre: Keresztyéni énekek, fakszimile, Bp., Balassi-MTA-ITI, OSZK, 41-48.

${ }^{514}$ Erről az énekről egyébként az unitárius egyháztörténet (KÉNOSI-UZONI, i.m., 801-802) tanúsága szerint az unitárius hagyomány úgy tartja, hogy Sztárai Miklós éneke, aki a fehérvári vita egyik bírája. Az unitárius hagyomány igyekszik tehát elperelni az éneket Sztárai Mihálytól.

${ }^{515} \mathrm{Ez}$ az ének bár Sztárai Mihályé, ám az egyháztörténet szerint az unitárius énekhagyomány az akrosztichonból kiolvasható Sztárai nevet igyekezett eltüntetni a versből. „Ennek az éneknek első versét ma már elhagyták, a második elejét pedig megváltoztatták, ezért a versfókből most Várai Mihály olvasható ki." (KÉNOSI-UzONI, i.m., 802.)

${ }^{516}$ A Hálaadásunkban rólad emlékezünk... (RPHA 478) megtalálható a zsoltárrészen kívül.

517 Mivel a protestáns hagyományt vizsgáljuk, így a zsoltárok számozása jelen fejezetben is a protestáns számozást takarja minden esetben.
} 
A 29. zsoltár parafrázisaként Újfalvi Imre Sztárai Mihály Szent Dávid próféta az Istennek nagy hatalmát látván... kezdetű zsoltárát hozza (RPHA 1308), az unitárius kiadás viszont ezt elhagyja, és Bogáti Fazakas Egész Izraelt... (RPHA 0313) kezdetű, az unitárius hagyományban igen népszerü parafrázisát hozza helyette.

$\mathrm{Az}$ unitárius kiadás hasonlóan jár el Szegedi Gergely Dávid prófétának imádkozásáról... (RPHA 0242) kezdetű zsoltáránál is: bár a Sztárai-szövegektől eltérően közli a Szegedi Gergely-éneket, de mellé illeszt egy Kochanowski-fordítást is alternatívaként, a Kitisztítván Absolonnak... kezdetüt (RMKT 17/4. 12. sz.). A 32. zsoltár esetében az unitárius kiadás ugyanezt alkalmazza: a Boldog az ilyen ember... (RPHA 199) kezdetü Szegedi Gergely-parafrázis mellé illeszt egy Kochanowski-fordítást, a Bünök soksága... kezdetüt (RMKT 17/4. 14.sz), mely ugyanennek a zsoltárnak a parafrázisa, az Újfalvi által közölt Sztárai-parafrázist, a Sok emberek vannak... (RPHA 1248) incipitüt viszont elhagyja.

Újfalvi Imre énekeskönyvében a 34., a 36. és a 37. zsoltár is Szárai Mihályé. (Mindenkoron áldom az én Uramat... (RPHA 983); Sok nyilvánvaló bizonyságokkal... (RPHA 1263) és Megnyomorult, szegény keresztyén ember... (RPHA 869).) Ezekből a Sztáraikból az unitárius egyet sem vesz be, hanem helyettük a 33. zsoltárt hozza Bogáti Fazakas Miklós A nagy bölcs teremtést... kezdetü énekével (RPHA 27), majd pedig az unitárius kiadásig nyomtatásból nem ismert, ismeretlen szerzőjü, Dóczi Zsuzsanna nevére írott 34. zsoltárparafrázisa következik, a Dicsérem az Urat minden időben... kezdetű. (RPHA 254, a többi forrásban más incipittel, mint az unitárius kiadásban: Dicsérem én az Istent.)

A 44. zsoltárig vizsgálva az 1602-15 közötti unitárius énekeskönyvet megállapíthatjuk, hogy hét Kochanowski-fordítás illetve lengyel mintára írott zsoltár szerepel abból a tízből, amelyet az énekeskönyv tartalmaz. Másfelől a teljes énekeskönyvbe felvett 12 Bogáti Fazakasból négy itt található meg. Azt mondhatjuk tehát, hogy az a rész, amely az 1602-es debreceni énekeskönyvben sok Sztárait tartalmazott, az unitárius énekeskönyvben az unitárius zsoltárszerzők/fordítók szövegeivel lesz tele.

Ugyanez a tendencia egyébként a zsoltárok többi részére is jellemző: a lengyel, illetve Kochanowski-fordítások és a Bogáti Fazakas zsoltárok többsége vagy főként Sztárait helyettesít az Újfalvi-féle kiadás tartalmához képest, vagy egy másik, a protestáns hagyományból ismert zsoltárparafrázis mellett találhatók meg.

A 60-70. zsoltárig Újfalvi Imre énekeskönyve csupán három parafrázist vesz be, ezek a következők:

63. zsoltár: Skaricza Máté, Saulnak az Dávidhoz való jó szerelme... (RPHA 1209)

64. zsoltár: Sztárai Mihály, Meghallgassad az én imádságomat... (RPHA 863) 
65. zsoltár: Sztárai Mihály, Sok jótéteményen nagy csudálkozván... (RPHA 1259) ${ }^{518}$

A 60-70. zsoltárokból az unitárius csupán kettőt közöl, és mind a kettő olyan zsoltárparafrázis, amely sehol nem jelent meg az 1602-15 közötti kiadást megelőzően:

66. zsoltár: Ismeretlen szerző, Egész Izraelnek népe... (lengyel fordítás, ${ }^{519}$ RMKT 17/4. 15. sz.)

69. zsoltár, Ismeretlen szerzö, Bánatában Dávid könyörög... (lengyel forditás, ${ }^{520}$ RMKT 17/4. 16. sz.)

Úgy tűnik, Sztárait az unitárius korpuszból kifejezetten igyekeztek a szerkesztők kivenni, mégpedig úgy, hogy a saját felekezetük szerzői által készített zsoltárfordításokkal, zsoltárokkal pótolják azokat. A korai protestáns énekszerzők közül Sztárai az egyetlen, akinek az énekei ilyen nagy számban tünnek el, kopnak ki az unitárius korpuszból, de megfigyelhető, (pl. Szegedi Gergely-énekek esetében), hogy az ismert protestáns énekszerzők népszerü zsoltárai mellé az unitárius nyomtatvány igen gyakran illeszt unitárius környezetben keletkezett parafrázist is.

Annak az okát, hogy miért pont Sztárai zsoltárai kopnak ki ilyen nagy számban az unitárius forrásból, sajnos nem tudjuk megmondani. Talán szerepet játszhatott ebben az, hogy Sztárai zsoltárai szemléletesen ,átkozzák” az ellenséget, panaszkodnak és könyörögnek az Úrnak az ellenség megtöréséért, hiszen Sztárai a zsoltárokat aktualizálva, a török elleni felszólalásra alkalmazta, az unitáriusok viszont igyekeznek „enyhíteni” az ellenség levágásáról, megtöréséről szóló zsoltárszövegeken. Egy másik, sokkal kevésbé valószínű, de lehetséges ok talán az, hogy Sztárai nyomán kezdődött meg a dunántúli reformáció. Nem kizárt, hogy a református harciasságot együtt látták mindazzal, ami Baranyában az 1570-es években történt, ahol az unitáriusok meggyőződése szerint ennek következményeként került sor Alvinczi György felakasztására. (Ezt alátámaszthatja a legutóbbi példa, amelyből kiderül, hogy a Sztáraik mellett a Skarica-szöveget is kiveszik az unitáriusok a 60-70. zsoltár parafrázisai közül. Skarica szerepet játszott a baranyai eseményekben, hiszen az a vitasorozat, amelyet a pécsi disputa megőrzött, bizonyos tekintetben az ő kezdeményezésére jött létre.) ${ }^{521}$ Mindemellett azzal a ténnyel is számolhatunk, hogy Sztárai zsoltárai erősen parafrazeálnak, $s$ az unitárius zsoltárhasználat (ld. pl. Bogáti Fazakas zsoltárai) igyekszik hű maradni a bibliai szöveghez.

\footnotetext{
518 Ács Pál kísérőtanulmánya, i.m., 44-45.

${ }^{519}$ PAPP Géza, i.m., ItK, 1961. 340.

${ }^{520}$ PAPp Géza, i.m., ItK, 1961. 340.

${ }^{521}$ A dunántúli unitáriusokról és protestáns hitvitákról bővebben: BALÁzS Mihály, Teológia és irodalom, Az Erdélyen kívüli antitrinitarizmus kezdetei, Bp., Balassi, 1998, 45-64 (Humanizmus és Reformáció 25).
} 
Úgy véljük, a protestáns hagyományból nem átvett szövegek is árulkodóak lehetnek, illetve az is, hogy mely protestáns zsoltárparafrázis mellé rendelnek saját, unitárius keletkezésű zsoltárokat. Ezek alapján egyértelműen látható az igény, hogy a gyülekezet által ismert, kedvelt protestáns szövegek megtartása mellett, annak figyelembevételével igyekeznek a nyomtatványok az unitárius hagyományon belüli énekeket is közölni. Ez a szerkesztői eljárás is mutatja, hogy a gyülekezeti énekeskönyveket nem lehet „fentről,” az egyházi vezetés által az egyik napról a másikra megváltoztatni, hiszen az évtizedek óta a protestáns hagyományból ismert, énekelt szövegek nem tűnnek el egyik napról a másikra, hogy azok helyét átvegyék egészen új énekek. A régi és az újabb (belső, unitárius) keletkezésű szövegek egyaránt jelen vannak, mert a szóbeli (énekelt) hagyomány a régebbi szövegek és dallamok ismeretén alapul, s ez nem hagyható figyelmen kívül egy a gyülekezet számára készített nyomtatványban.

\section{2. 2. Apró mikrofilológiai adalék az RMKT 17/4. lengyel zsoltárfordításainak kiadásához}

A lengyel zsoltárok magyar fordításainak az RMKT 17/4.-ben megjelent kritikai kiadását egy ponton kiegészíthetjük egy apró, ám talán említésre érdemes mikrofilológiai észrevétellel. Az RMKT 17/4. 13. számú éneke a 31. zsoltár parafrázisa, és Papp Géza is beveszi a Kochanowski-fordításokról szóló dolgozatába, ${ }^{522}$ de forrását pontosan azonosítani nem tudja. A zsoltár egyébként csak az 1602-15 közötti unitárius énekeskönyvben van meg, másutt tudomásunk szerint nem fordul elö. Ez a zsoltár az RMKT-ban csonkán szerepel, s a zsoltár jegyzetében a következőket írják magyarázatul: „,korrigálás közben vettük észre, hogy e sor után $k b$. 9 versszak hiányzik, mert a nyomtatvány csonka: a 236-7. lap, vagyis a $K$ iv utolsó levele kiszakadt." ${ }^{, 523}$ A saját, a marosvásárhelyi Teleki Tékában fotózott kiadásról készített átiratomat összevetve az RMKT-val feltűnt, hogy nekem teljes a szövegváltozatom, és mint ilyen, minden lengyel zsoltárfordításhoz hasonlóan a zsoltár értelmét, tartalmát tükröző akrosztichont is ad: ISTENFELÖ NE FELLI ALLI. Megnézve a fotómásolatom oldalszámait az is világos lett, hogy a 236-237. lap nem egy levélen van, a 235-36. oldalak és a 237-38. oldalak vannak egy-egy levélen. Így lehetetlen, hogy egy - de akár mindkét - levél

\footnotetext{
${ }^{522}$ PAPP Géza, i.m., ItK 1961.
}

${ }^{523}$ RMKT 17/4. 546. 
kiszakadásáról beszéljünk, hiszen az RMKT közli a 235. és a 238. oldalon található strófákat is. Kikértem az OSZK-ban található, a Teleki Téka példányáról készített mikrofilm digitalizált változatát, amelyböl kiderült, hogy a 236. és a 237. oldal hiányzik, nem fotózták be. Így a történelmi helyzet miatt - t. i. a kritikai kiadás készítői a marosvásárhelyi példányt csak fotómásolatban tudták elérni - ez az ének csonkán került be a kritikai kiadásba. Apró filológiai pontosítás, de mivel ez az egyetlen példányunk van ebből a szövegből, talán nem felesleges közölni a teljes zsoltárt, mert ez minden bizonnyal egy olyan 16. századi parafrázissal állunk szemben, amely a 17. századból egy változatban maradt csupán fönn.

\section{Psalmus XXXI.}

Nota Pol. vel Légy irgalmas, Úristen...

Istenben bízván Dávid énekel, harmincegyedszer énekesivel, sok nyavalyák közt nagy reménységgel, int minket, Istent fogjuk meg hittel.

Sok nyavalyák közt benned, Úristen, csak biztam, s soha nem talált szégyen, igazságodból szabaduljak én, hajtsd hozzám füled, ments meg idején.

$T e^{524}$ légy énnékem erōs köszálam, légy erös helyem, had tartattassam, mert te vagy nekem az én köszálam, keritésem és erős kőváram.

Ezért, Úristen, és szent nevedért, viselsz és hordosz, vígy ki kedvedért, a nagy hálókból erösségedért, melyet vetettek én romlásomért.

Neked, szent Atyám, és szent kezedbe, ajánlom lelkem én igaz hitbe, megszabaditál kegyességedben, erös és igaz Jehova Isten.

Felette gyülöltem babonásokat, mert én Istenben bízom, s hálákat adok, vígan, s irgalmasságodat áldom, mert látom sok nyavalyámat.

És megvigasztalád lelkem fájdalmát, nem hagyád, Uram, ellenség markát, hogy engem kapna, s én lábaimat bátor helyre vőd, és megállatád.

Légy irgalmas már Úristen nekem, mert keserüség szorongat engem, szivem és lelkem, és minden részem elszáradt, mert fogy kínban életem.

${ }^{524}$ Innentől az RMKT nem hozza, a nyomtatványt csonkultnak mondja. 
Örömöm helyén fohászkodásban foly én esztendöm, erőm fogyásban, álnokság miatt csontom szupságban [!], elemésztődik szintén bánatban.

Nagy csúfolásban ellenségimnél, szomszédságimnál, ismerőimnél, iszonyú voltom, távol tekintél, fut minden tölem, aki földön él.

Elfelejtettek mint holt s rossz edényt, mert gyalázatot hallok, sok rút hírt, minden rettegést ellenem indit, ellenség nekem hálókat készít.

Felséges ${ }^{525}$ Isten, én pedig bizom csak felségedben, nagy hittel mondom, én Istenem vagy, kezedben napom, óvj kezétöl, ki gyülöl, s üldözöm.

Engedjed orcád tündökjék rajtam, tarts kegyelmedböl, nagy szent Jehovám, ne szégyenüljek, téged hívlak, nám, szégyen, ellenség elfogy úgy, mint vám.

Lágy ajaki némulnak hazugnak, kik igaz ellen kemény szót szólnak, kevélységekböl kik pirongatnak, felfuvalkodtak, s mindent utálnak.

Lásd, mely végtelen Isten, jóvoltod, azt pedig töled félöknek tartod, kik hozzád futnak, azoknak nyújtod, hogy ember lássa, nyilván mutatod.

Íme, elrejted rejtö színeddel öket, s kevélyek nagy keménységgel ne sértsék, hajlékodba békével beviszed, hogy ne rágják nyelvekkel.

Áldott legyen a Jehova Isten, mert megmutatá nagy csodaképpen, irgalmasságát rajtam kegyesen, a keritett városban. Úgy legyen.

Lásd, de igy szólék hertelenségböl, kivágattam én szent szined elöl, de meghallgatád szóm kegyelmedböl, kérésem mikor kiálték hitböl.

Legyetek szentek nagy szeretetben az Uristenhez, mert az Úristen örzi hiveket, mert fizetésben böven, kik vannak nagy kevélységben.

Igen erősen álljon már minden, és megerösiti szívetekben,

${ }^{525}$ Innentől az RMKT 17/4-ben is megvan az ének. 
mindnyájan, akik biztok Istenben,

úgy legyen, mi is mondjuk mind, amen.

\section{2. 3. A lengyel forrású zsoltárok verstani, poétikai sajátosságai}

A lengyel zsoltárfordítások metruma a későbbi, ismeretlen szerzőjü unitárius énekeket bemutató fejezetben még fontos lesz, de érdemes a kérdést ettől függetlenül is megemlíteni. Ahogyan arra Papp Géza is rámutat, ${ }^{526}$ a lengyel dallamokra írott magyar zsoltárok között találunk szapphikus formában írottat, ez a 16. zsoltár, az Ó nagy Úristen, a szent Dávid király... kezdetü, metruma: a11 a11 a11 a5. A 32. zsoltár magyar fordítása szintén szapphikus sorokból áll, ennek a metruma a11 a11 a11 a11. Ezzel a metrumképlettel még egy lengyel hatást mutató zsoltár, a Bánatában Dávid... kezdetü rendelkezik. Ezen kívül a 10 szóban forgó zsoltárból egy a10 a10 a10 a10-es metrumú (Istenben bizván Dávid énekel...). A Jaj meddig, nagy Úristen... kezdetű, a 13. zsoltár parafrázisát Papp Géza vágáns 13-asként azonosítja, ${ }^{527} \mathrm{~s}$ ennek a zsoltárnak nincs magyar nótajelzése az 1602-15 közötti unitárius énekeskönyvben, csupán „Nota Pol.” jelzéssel van ellátva. Feltűnő azonban, hogy ugyanilyen 13-asokban íródik Balassi Bálint Áldj meg minket... kezdetű éneke, melyet ő is lengyelből fordított. A többi, az unitárius kiadásokban szereplő, lengyel nótajelzéssel ellátott 5 ének a 10ből mind 4 x a8-as metrumú, mely annak ellenére, hogy a 16. századi magyar költészetben is rendkívül kedvelt forma, a lengyel költészetnek is az egyik leggyakoribb formája, melyet Kochanowski is előszeretettel használt. Az öt énekből kettőnél ${ }^{528}$ nemcsak a „Nota Pol.” jelzéssel találkozhatunk, hanem magyar nótajelzésként az 1602-15 között megjelent kolozsvári énekeskönyvben Balassi Bálint Ó, én kegyelmes Istenem ... kezdetű (RPHA 1109), Balassi lengyelországi évei alatt készített szövege is meg van adva. Nótajelzésnek mindig a gyülekezet által jól ismert szövegeket hivatkoznak, ahogyan azt már a korábbi fejezetben láttuk, így nem tekinthetünk el attól, hogy Balassinak ez az éneke 1602-15 körül az unitárius gyülekezet számára ismert szöveg volt. Ezt a dolgozat a későbbiekben, a korai Balassihagyomány tárgyalásakor még részletezi, fontosnak véljük azonban megemlíteni, hogy a lengyel zsoltárok magyar fordításai éppen Balassi Bálint Lengyelországban keletkezett énekét hozzák nótahivatkozásul, egyébként pedig az sem kizárt, hogy Balassinak ez az éneke - a

\footnotetext{
${ }^{526}$ PAPP Géza, i.m., ItK, 1961, 338.

${ }^{527}$ PAPp Géza, i.m., ItK, 1961, 338.

${ }^{528}$ Reménységem vagy, Istenem... és az Ím, s hogy kiált Istentelen...
} 
legkedveltebb lengyel metrumban írva - esetleg Kochanowski, vagy legalábbis lengyel zsoltárfordítás, illetve átdolgozás. ${ }^{529}$

A Papp Géza által lengyel forrásúnak azonosított zsoltárok mindegyikére jellemző, hogy a Bogáti Fazakas-zsoltárokhoz hasonlóan olyan akrosztichonnal rendelkeznek, amelyek a bibliai zsoltárok lényegi mondandóját, velejét adják vissza. Tételmondatként, a vers lényegét visszaadó argumentumként is értelmezhetőek. Például a Bánatában Dávid... kezdetű, 69. zsoltárnak az akrosztichonja a következő: Bánat bánt, siess, Úristen, segélj, amen. A Bibliában ez a zsoltár Az Úr szolgája a legnagyobb szenvedésekben címmel szerepel, tehát a zsoltárt éneklő élethelyzetét pontosan visszaadja az akrosztichon. Pap Balázs kifejti Bogáti Fazakas akrosztichonjainak vizsgálata kapcsán, ${ }^{530}$ hogy az ilyen, ,argumentumocska” jellegü akrosztichonnak mnemotechnikai jelentősége is van, hiszen az ilyen jellegü argumentumok alkalmazása a zsoltár lényegének összefoglalása által a zsoltár egyes versszakainak sorrendjét is segítenek megtartani, fejben tartani.

Alább táblázatban összefoglalva bemutatjuk, mely zsoltárhoz milyen akrosztichont rendel az ismeretlen fordító:

\begin{tabular}{|c|c|c|}
\hline $\begin{array}{l}\text { Zsoltárszám }{ }^{531} \text { és } \\
\text { RMKT szám }\end{array}$ & Incipit & Akrosztichon $^{532}$ \\
\hline $\begin{array}{l}5 . \\
\text { RMKT 17/4. 8.sz. }\end{array}$ & $\begin{array}{l}\text { Isten, kegyes füled } \\
\text { szómat... }\end{array}$ & $\begin{array}{l}\text { IDEIEN KERÖNEK } \\
\text { AD URA }\end{array}$ \\
\hline $\begin{array}{l}13 . \\
\text { RMKT 17/4.9. sz. }\end{array}$ & $\begin{array}{l}\text { Jaj, meddig, nagy } \\
\text { Úristen... }\end{array}$ & JÜ AZ ÚR \\
\hline $\begin{array}{l}14 . \\
\text { RMKT 17/4. 10. sz. }\end{array}$ & $\begin{array}{l}\text { Ím, s hogy kiált } \\
\text { Istentelen... }\end{array}$ & ISTEN VELÖNK \\
\hline $\begin{array}{l}16 . \\
\text { RMKT 17/4. 11. sz. }\end{array}$ & $\begin{array}{l}\text { Ó, nagy Úristen, a } \\
\text { szent Dávid király... }\end{array}$ & OII ÚR S TARTS \\
\hline $\begin{array}{l}30 . \\
\text { RMKT 17/4. 12. sz. }\end{array}$ & $\begin{array}{c}\text { Kitisztitván } \\
\text { Absolonnak undokságát... }\end{array}$ & $\begin{array}{l}\text { KEGJELMES AZ MI } \\
\text { URUNK }\end{array}$ \\
\hline
\end{tabular}

\footnotetext{
${ }^{529}$ Bár a figyelmet e tényre fel tudjuk hívni, a kutatás jelenlegi fázisában ennél többet nem tudunk megállapítani, ez a kérdés nyitott a további vizsgálatokra.

${ }^{530}$ PAP Balázs, i.m., 132.

${ }^{531}$ A zsoltárok számozása itt is a protestáns használatot követi.

${ }^{532} \mathrm{Az}$ akrosztichonokat a saját átírásom alapján hozom, így nem mindig azonosak az RMKT 17/4. kötetében találhatókkal.
} 


\begin{tabular}{|c|c|c|}
\hline $\begin{array}{l}31 . \\
\text { RMKT 17/4. 13. sz. }\end{array}$ & $\begin{array}{l}\text { Istenben bízván Dávid } \\
\text { énekel... }\end{array}$ & $\begin{array}{l}\text { ISTENFELÖ NE } \\
\text { FELLI ALLI }\end{array}$ \\
\hline $\begin{array}{l}32 . \\
\text { RMKT 17/4. 14. sz. }\end{array}$ & $\begin{array}{l}\text { Bünnek soksága } \\
\text { hogyha kit iszonyit... }\end{array}$ & $\begin{array}{c}\text { BOTSASD } \\
\text { BÜNÖMET URISTEN }\end{array}$ \\
\hline $\begin{array}{l}66 . \\
\text { RMKT 17/4. 15.sz. }\end{array}$ & $\begin{array}{l}\text { Egész Izraelnek } \\
\text { népe... }\end{array}$ & $\begin{array}{c}\text { ERÖS AZ MI } \\
\text { ISTENÜNK NO DITSIRIÖK }\end{array}$ \\
\hline $\begin{array}{l}69 . \\
\text { RMKT 17/4. 16. sz. }\end{array}$ & $\begin{array}{l}\text { Bánatában Dávid } \\
\text { könyörög ígyen ... }\end{array}$ & $\begin{array}{l}\text { BANAT BANT SIES } \\
\text { URISTEN SEGELI AMEN }\end{array}$ \\
\hline $\begin{array}{l}71 . \\
\text { RMKT 17/4. 17. sz. }\end{array}$ & $\begin{array}{l}\text { Reménységem vagy } \\
\text { Istenem... }\end{array}$ & $\begin{array}{l}\text { REMENSEGEM } \\
\text { ISTENBEN SZABADITS } \\
\text { ENEKLEK EN }\end{array}$ \\
\hline
\end{tabular}

Azok a zsoltárok, amelyeken a lengyel hatást Papp Géza kimutatta, minden esetben tartalmaznak hivatkozó strófát a zsoltár számára, és minden esetben a protestáns zsoltárszámozást követik. Egyetlen olyannal találkozunk, melyben a hivatkozó strófa elrontja a zsoltárszámot: a 30. Psalmus címet viselő, Kitisztítván Absolonnak... incipitű zsoltár hivatkozó strófája 32. zsoltárt ad meg annak ellenére, hogy a zsoltár a 30. zsoltár fordítása, és a címben helyesen is szerepel. A tíz vizsgált psalmusból négynek az első strófája mondja meg, hogy melyik zsoltárról van szó, hatnak pedig az utolsó versszakában találunk a számozásra utaló hivatkozást. Olyan esettel nem találkozunk, hogy az elején is, a végén is legyen hivatkozás: vagy az egyiket, vagy a másikat tartalmazza.

A lengyel zsoltárfordítások mindegyikének utolsó versszakában szerepel az Amen szó, amellyel lezárja az elénekelt zsoltárt a zsoltárban megszólaló könyörgő vagy hálaadó funkciónak a teljesüléséért való kérésképpen.

A retorikai alakzatok, a trópushasználat szempontjából egyértelműen mondhatjuk, hogy az ismeretlen fordító nem vitte túlzásba azok használatát: a protestáns zsoltárok nyelvezetéhez hűen igyekszik tisztán, érthetően, ha lehet, bonyolultabb metaforika nélkül visszaadni a zsoltár jelentését. Feltünő viszont, hogy a bibliai zsoltárok hasonlatait hüen követi, ezeket a hasonlatokat mindig megtartják a szövegek.

Ilyen például az Egész Izraelnek népe... incipitü, 66. zsoltár hasonlat-használata a 11. strófában:

Te Úristen, hogy voltunkat,/megpróbálád állásunkat,/ mint ezüstre tüznek lángját,/ úgy reánk is a nagy próbát. 
Ez a strófa az alaphasonlatot átveszi, ám a tisztító tüz értelmezési lehetőséget elhagyja, mely a Károli-fordításban megtalálható: Zsolt. 66,10.:

Mert megpróbáltál minket, oh Isten, megtisztitottál, a mint tisztitják az ezüstöt.

Ahol az ismeretlen fordító egy a Bibliában található hasonlatot átültet, ott az sem ritka, hogy a hasonlat pontos, jól és könnyen érthető magyarázatát is megadja még akkor is, ha ezzel a bibliai zsoltár egy szakaszát több strófányira kell bővíteni. Tisztán, jól érthető szöveget igyekszik létrehozni a szerző-fordító. A hasonlatok kifejtését jól példázza a 32. zsoltár parafrázisának (Bünnek soksága hogyha kit iszonyit...) 17-18. strófája, mely a bibliai zsoltár egy, hasonlatot alkalmazó szakaszát két strófában mondja el. A hasonlat előtti, utáni strófák is követik a bibliai gondolatmenetet: azaz egy bibliai szakasz egy versszakban van kifejtve.

Zsolt. 32,9: Ne legyetek oktalanok, mint a ló, mint az öszvér, a melyeknek kantárral és zabolával kell megszoritani az állát, mert nem közelít hozzád.

Bünnek soksága ... 17-18. strófa:

Igen szorgalmas gondja legyen arra/ minden embernek, s magát úgy hordozza,/ nem mint a lovak vagy öszvérek dolga, / értelem nélkül, nagy ostobaságba.

Súlyos és éles zabolával kiknek/szájukat s'vastag fékemlök viselnek, / úgy kényszerítik, hogy ök engedjenek, / fene voltukkal senkit ne sértsenek.

Ez a tíz zsoltár az általában vett protestáns zsoltárköltészeti úzushoz képest főleg grammatikai-verstani szempontból tartalmaz markánsan elkülönülő, sajátos jegyeket.

Az anaphora, az epiphora és az epandosz sajátos alkalmazása, ismétlésekkel, rokon jelentésű szavak felsorolásával tarkított folyamatos, gyakran egyidejü jelenléte számos helyen megtalálható ezekben a zsoltárokban. Néhány példával szemléltetve:

Istenben bizván Dávid énekel... (31. zsoltár), 3. vsz.:

Te légy énnékem erős kőszálam,/ légy erős helyem, had tartattassam,/ mert te vagy nekem az én köszálam,/ keritésem és erős kőváram.

Nem ritka, hogy ezek a speciális ismétlődésen alapuló alakzatok nem egy strófán belül találhatók. Ilyen például az Ím, s hogy kiált... incipitü ének 1-2. versszakában található sehol Isten-sehol nincsen ismétlödés:

Ím, s hogy kiált Istentelen,/ szívében szól ily képtelen,/ nincsen nyilván sehol Isten,/ ki vigyázna mindeneken.

Sehol nincsen, ki jót tégyen,/ megveszett már nagy hirtelen/ az emberség, s tökélletlen,/ vakmerővé lett már minden. 
A fenti példák már azt is mutatják, hogy ezekben a zsoltárokban a soráthajlás és a közölések milyen gyakran fordulnak elő. Egyes zsoltárok domináns poétikai szervezőelvévé válnak a közölések és a soráthajlások, olyannyira meghatározó szereppel bírnak.

Soráthajlással több olyan esetben is találkozhatunk, amely nem egy strófán belül megy végbe. Az ismeretlen szerző egy esetben összeköt két strófát a soráthajlással, amellyel a régi magyar vers esetében igen ritkán találkozhatunk, hiszen a legtöbb esetben egy mondat, egy gondolatmenet egy strófa, mi több, gyakran egy sor. Ez a két strófa közti gondolat- és soráthajlás $O$, nagy Úristen... kezdetű 16. zsoltár 2. és 3. strófája között található, s itt is megfigyelhetjük a soráthajláson kívül a számos közölést, ismétlést.

2. vsz. Igen figyelmes légy megtartásunkra,/ mert mi csak bíztuk magunkat magadra./ Szólok Istennek, te vagy híved Ura,/ te minden jónkra

3. vsz. Igen figyelmesz, noha nincsen szükséged / semmi mi jónkra. Engem a te néped, /kit választottál e földön, s vezérled, / csak gyönyörködtet.

Szinte az egész zsoltár közölésekkel ellátott strófákból áll az Isten kegyes füled szómat... kezdetü 5. zsoltárban. Ennek az első két strófája:

Isten kegyes füled szómat,/ hallja mostan beszédemet,/ tekintsed meg én elmémet/ ne vessed el kérésemet.

Derékképpen kiáltásom,/ halld meg valóban panaszom,/ én Istenem, s én királyom,/ könyörgésem hozzád nyújtom.

A sok közölés, a megszokott szórendtől való eltérés egy esetben nagyon rejtetten, nagyon óvatosan, de dogmatikai értelemben igen radikálisnak számító értelmezésre is lehetőséget ad. Az Egész Izraelnek népe... kezdetű zsoltár 13. strófája tartalmazza egyébként az egyetlen krisztianizáló, Krisztusra utaló szöveghelyet a 10 vizsgált zsoltár közül:

13. Nem tekinted méltóságunk,/ melyre fiad által juttunk,/ de halandó ember vallunk,/ úgy akarád, nyomja nyakunk.

14.Üstökön fogva hordozott,/ mi fejünkre ült és állott,/ mind tüzzel-vízzel fogyatott,/ mert felséged ostorozott. 
Az idézett szövegrészben arról van szó, (mely a következő versszak segítségével értelmezhető pontosan) hogy a halandó emberek, akik méltóságra jutottak az Úristen fia által, az Isten ostorozása miatt más népek elnyomásától szenvednek.

A közölések miatt a fent idézett strófát igen nehézkesen lehetett értelmezni. Az értelmezési nehézségek elkerülése érdekében a nyomtatott kiadásokban egyébként gyakori a zárójelek használata a lengyel zsoltároknál. Erre példa az Ó, nagy Úristen... kezdetű zsoltár első, bevezető versszaka:

Ó, nagy Úristen, (a szent Dávid király,

tizenhatodik énekében kit hálál,

ékes szózattal mi szivünk is talál,)

a mi pártunkon állj.

A már többször említett Ím, s hogy kiált... kezdetü ének 6. strófájában is találkozunk a nem szokványos szórend megértését a zárójelhasználat által segítő megoldással:

Vigadoznak hogy már nagyon

esznek-isznak ők nagy bátron,

az Úristen, (kitöl vagyon

minden jó csak) távol vagyon.

A lengyel forrású zsoltárok esetében feltűnő, hogy a szerző-fordító olykor több strófán keresztül, hosszasan ecseteli önreflexív módon, hogy hogyan áldja, dicséri az urat, énekel, szóval/szájjal mondja/könyörög az Istenhez stb. Hangszeres zene egyetlen alkalommal, az Egész Izraelnek népe ... kezdetű zsoltár bevezetőstrófájában, Dávidra vonatkoztatva fordul elő csupán:

Egész Izraelnek népe,/ az Úristent hogy dicsérje,/ inti öket Dávid kedve,/ hegedüje és éneke.

Ugyanennek a zsoltárnak a 2. versszaka is jó példa a számos éneklésre való reflektálásra:

Rengjen a föld víg örömmel,/szent nevének énekléssel,/ dicsérjétek nagy jó kedvvel/ dicsöségét nagy hüséggel.

Feltűnő, a protestáns zsoltárok szóhasználatában rendkívül ritka az, hogy az éneklést, az Isten dicsőítését „tapsolással” kísérjék, s itt szinte minden énekben megtalálható, ahogy a példák is mutatják:

Uram Isten, felségedben/tapsolunk lelki örömben... (Isten kegyes füled... 16. vsz.) 
Legyen dicséret Istennek,/ szenti között Felségének,/ áldassék neve, mindenek/ tapsoljanak kegyelmének. (Kitisztítván Absolonnak... 6. vsz.)

Tapsolván azért áldom az Úristent... (Ó, nagy Úristen... 7. vsz.)

Kicsinytöl fogván nagyiglan/ énekeljünk mi tapsolván... (Ím, s hogy kiált... 11. vsz. hivatkozó strófa)

....segedelmedben való igaz vigassággal,// teljes szívböl örvendek lelki tapsolással. (Jaj meddig, nagy Úristen... 5. vsz.)

No örüljetek mindnyájan Istenben,/ és tapsoljatok, igazak, örömben,/ énekeljetek lelki ismeretben,/ mindnyájan mondjuk Úristennek, amen. (Bünnek soksága... 21. - utolsó versszak.)

Összegezve az eddig a lengyel zsoltáranyagból átkerült zsoltárok sajátosságait: a legtöbb esetben a lengyel költészet jellemző metrumait használják, s nótajelzésük minden esetben Nota Pol(onica), néhol magyar alternatívát is kínálva melléje. Minden zsoltárnak van akrosztichonja, amely argumentumszerủen a zsoltár lényegi mondandóját foglalja össze csakúgy, mint Bogáti Fazakas Miklós zsoltárainál.

A zsoltárok szövegeiben minden esetben - néhol az első, másutt az utolsó strófában található hivatkozás a bibliai zsoltárra, a protestáns számozás szerint. Mindegyik zsoltár utolsó strófájában megtalálható az Amen kifejezés. Bonyolult trópusokat, retorikai eszközkészletet nem mutatnak fel, a bibliai hasonlatokat viszont átveszik. A szövegek gyakran anaphorikus szerkesztésüek, közölésekkel és soráthajlásokkal gazdagon ellátottak, melyek olykor a strófák határain is túlmennek. A közölések, a szokatlan szórend miatt több alkalommal használ az 1602-15-ös unitárius nyomtatvány zárójeleket. Nyelvezetükre jellemző, hogy a bibliai zsoltároknál gyakrabban tartalmaznak az éneklés, a hálaadás szempontjából önreflexív elemeket, az Isten dicsőítésének említésekor „tapsolással” kísérve azt, de nem hangszerrel.

\section{3. Megfigyelések néhány ismeretlen szerzőjü, csak unitárius forrásban szereplő zsoltárról}

Már az unitárius énekanyagot kiadó RMKT 17/4. kötetének jegyzetében is megtaláljuk, hogy a lengyel fordítások és bizonyos, csak unitárius forrásban szereplő szövegek között olyan szoros a kapcsolat, hogy azok talán egy szerzőtől származhatnak. Az 
RMKT egymás után hozza ezeket a szövegeket 8-24. szám alatt, (de a 24.-et nem tartja szorosan ide tartozónak) és az egy szerzőtől származásuk bizonyítékát stiláris azonosságban, illetve az akrosztichonok hasonlóságában látja. ${ }^{533} \mathrm{Az}$ RMKT-val egyetértve a következőkben azt kívánjuk bemutatni, hogy a tíz lengyel zsoltárfordításon kívül találunk még hat olyan szöveget, amelyek csak unitárius forrásban hagyományozódnak, és poétikai sajátosságaik igen hasonlóak az imént elemzett lengyel forrású zsoltárokéval, így nem kizárt, hogy a zsoltárszerző illetve fordító személye egy.

Az előző fejezethez hasonlóan itt is zsoltárszámmal, RMKT-számmal, incipittel és versfökkel fogjuk táblázatosan bemutatni a szóban forgó énekeket. Az akrosztichonokra ugyanis az jellemző, ami a Kochanowski-zsoltárok fordításaira: Bogáti Fazakas zsoltáraihoz hasonlóan minden ismeretlen szerzőjü, szóban forgó zsoltár olyan akrosztichont ad, amely rövid argumentumként, a zsoltár fö mondandójának összefoglalásaként értelmezhető.

\begin{tabular}{|c|c|c|}
\hline $\begin{array}{l}\text { Zsoltárszám és } \\
\text { RMKT 17/4. szám }\end{array}$ & Incipit & Akrosztichon \\
\hline $\begin{array}{l}\text { 86. zsoltár } \\
\text { RMKT 17/4. 18.sz. }\end{array}$ & $\begin{array}{l}\text { Erös ellenségtöl } \\
\text { mikor Dávid király... }\end{array}$ & $\begin{array}{l}\text { ESETEM ÖRÜLIK } \\
\text { SEGELI ÚR }\end{array}$ \\
\hline $\begin{array}{l}\text { 89. zsoltár } \\
\text { RMKT 17/4. 19. sz. }\end{array}$ & $\begin{array}{l}\text { Nagy irgalmasságát a } \\
\text { felséges Istennek... }\end{array}$ & $\begin{array}{l}\text { NE FELI EGIEL } \\
\text { IGJAL KEGIELMES ASz } \\
\text { ÚR }\end{array}$ \\
\hline $\begin{array}{l}\text { 100. zsoltár } \\
\text { RMKT 17/4. 20. sz. }\end{array}$ & $\begin{array}{l}\text { Az Úristent az egész } \\
\text { föld... }\end{array}$ & AMEN \\
\hline $\begin{array}{l}\text { 103. zsoltár } \\
\text { RMKT 17/4. 21. sz. }\end{array}$ & $\begin{array}{r}\text { Áldjad lelkem } \\
\text { mindenkor az Urat... }\end{array}$ & $\operatorname{AMEKE}(?)^{534}$ \\
\hline $\begin{array}{l}\text { 103. zsoltár } \\
\text { RMKT 17/4. 22. sz. }\end{array}$ & $\begin{array}{l}\text { Áldjad lelkem az } \\
\text { Úristent... }\end{array}$ & $\begin{array}{l}\text { ALGIAD LELKEM } \\
\text { URADAT AMENN }\end{array}$ \\
\hline
\end{tabular}

${ }^{534}$ Bár az RMKT ezt az éneket is a többivel azonos szerzőjünek mondja, a leginkább ez tünik számunkra a többitől eltérőnek: az akrosztichonja nem rekonstruálható, pedig a többi esetében világosan látszik, hogy igyekeznek értelmes akrosztichont hozni. Ennek persze lehet az oka az is, hogy korábban keletkezett az ének, mint a többi. Ezen kívül, ahogy azt a későbbiekben látjuk, minden ismeretlen szerzőjü ének - a lengyelböl fordított zsoltárokhoz hasonlóan - az utolsó strófájában Ament szerepeltet, de ez a zsoltár nem, annak ellenére, hogy az utolsó strófája hivatkozó strófa, tehát befejezettnek tünik. Ezen kívül ez a zsoltár a 103. zsoltár átdolgozása, és a 103. zsoltárnak másik ismeretlen szerzőjü parafrázisa is van, az Áldjad lelkem az Úristent... kezdetü, mely szintén csak unitárius forrásban található meg. Ez a zsoltár pedig sokkal inkább hasonlít - az RMKT szóhasználatával élve - stílusában a többi ismeretlen szerzőjü énekre és a lengyel zsoltárokra, mint a szóban forgó Áldjad én lelkem mindenkor... incipitű zsoltár.
} 


\begin{tabular}{|l|l|l|}
\hline $\begin{array}{l}\text { 116. zsoltár } \\
\text { RMKT 17/4. 23. sz. }\end{array}$ & Oelkem... & $\begin{array}{l}\text { EORVend Uram az én } \\
\text { URBAN SzABADULVAN } \\
\text { E }\end{array}$ \\
\hline
\end{tabular}

Az akrosztichonok itt is a versek lényegi tartalmát közvetítik. A Kochanowskifordításokhoz hasonlóan ezek a szövegek is minden esetben tartalmaznak hivatkozó strófákat, amelyekben a protestáns zsoltárszámozást használják. A hat énekből csak egynek van az elején ez a hivatkozó strófa, a többinek a végén található. A záró versszakok két kivétellel minden esetben tartalmazzák itt is az Ament, e két kivételre viszont van magyarázat. Az egyik a már a táblázatnál is említett Áldjad én lelkem... kezdetü ének, a 103. zsoltár parafrázisa, mely - bár az RMKT szerint ide tartozik - a szóban forgó szövegek közül a legtöbb különbséget tartalmazza a többitől, így talán eltekinthetünk attól, hogy ugyanaz a szerzője, mint a többinek.

A másik, a záró strófában Ament nem szerepeltető zsoltár az Örvend Uram az én lelkem... kezdetü. Ennek az akrosztichonja a következő: EORVENDEK ASz URBAN SzABADULVAN E. Az utolsó előtti strófában ott találjuk az Amen kifejezést, viszont ez a versszak nem tartalmaz hivatkozást a zsoltárszámra, míg a záró versszak igen. Így valószínünek tartjuk, hogy az elmaradt hivatkozó strófát utólag toldották a szöveghez, s az akrosztichonban a felesleges „E” is ezt látszik alátámasztani. Az utolsó két versszak a következő:

Nagy örömmel rövid nap hogy láthassam/ szerelmesimet, Úristen, és áldjam/ jó voltodat, örvendezvén egyemben, /dicsértessék az Úr örökké, Amen. ${ }^{535}$

Éneklé kiszabadulván mindenben,/ a szent Dávid száztizenhat énekben,/ Isten ötet megtartá ekképpen,/ ki ezt mondja, látá, s várja örömben.

Ilyen, feltehetően utólag odakerült hivatkozó strófa található egyébként az Áldjad lelkem az Úristent... kezdetű zsoltárban is. Ennek akrosztichonja: ALGIAD LELKEM URADAT AMENN. Az „Amenn” első N-jével kezdődő strófa a többi ilyen jellegű zsoltárhoz hasonlóan tartalmaz Ament, de nem hivatkozza a zsoltár számát. Az utolsó versszak viszont igen, ám ez a versben végig tartott a13 a13-s (néhol x13-asra módosulva) metrumot megváltoztatja, nem tartja a zsoltárban addig tartott metrumot, így itt is az utólagos betoldást feltételezhetjük:

\footnotetext{
${ }^{535}$ Már ezen a strófán is látható, hogy a lengyel zsoltárok fordítójának eljárásához hasonlóan itt is rengeteg közöléssel, soráthajlással találkozunk.
} 
Nagy és kicsiny minden dolgi Urat dicsérvén/ áldjad, áldjad, oh én lelkem Úristent, Amen.

Nagy örömmel bünének bocsánatát nyervén/ Dávid király százharmadszor örvendez Amen, Mi is nyertünk kegyelmet, mondjuk azért Amen.

Az idézett zsoltárok metruma ${ }^{536}$ is hasonló, mint a lengyel fordításoké: találunk szapphikus strófájúakat (Nagy irgalmasságát a felséges Istennek... és az Áldjad én lelkem...), vágáns 13-ast, (Erös ellenségtöl...), de a11 a11 a11 a11-es metrumút is (Örvend, Uram az én lelkem...), és a lengyel fordítások leggyakoribb metruma, az a8 a8 a8 a8-as is megtalálható (Az Úristent az egész föld...).

Ezek az énekek tehát zömmel olyan metrumúak, mint a lengyel zsoltárok fordításai.

Ezek közül a zsoltárok közül egy sem krisztianizál, de ugyanúgy erősen meghatározza a zsoltárok jellegét a többstrófás, az éneklésre, a hálaadásra, az Isten dicsőítésére vonatkozó folyamatos reflexiók gyakorisága, mint azt a lengyel zsoltárfordításoknál láttuk. A lengyel zsoltároknál is megfigyelhető, hogy az Úristen „füleinek megnyitására” irányuló kérések, kifejezések ott is gyakoriak, ahol az eredeti zsoltárokban ezeket hiába keresnénk. Ezek itt is gyakran az Istenhez könyörgő, éneklö, őt dicsérö önreflexív környezetben jelennek meg, Dávid hangján szólalnak meg tehát, de az minden esetben oda van kölcsönözve az aktuális zsoltárt éneklőnek. A zsoltárokban megjelenő lelki éneklések, dicséretmondások itt sincsenek hangszerhez kötve egyik esetben sem, csupán a „tapsolás” fordul elő.

Mivel ezekben a zsoltárokban is együtt, egymástól nehezen elválaszthatóan jelennek meg a kifejtett poétikai sajátosságok, akkor járunk el helyesen, ha az elmondottakat alább néhány példával szemléltetjük.

Az Örvend, Uram... kezdetű zsoltár első három strófája példa a dicséretmondással kapcsolatos hosszú reflexióra, melyben a tapsolás, a „szent fülek” megnyitása is szerepel:

Örvend Uram az én lelkem tebenned,/ repes szívem tapsolással elötted,/ dicsekedem, hogy meghallgat Felséged,/ szám és elmém szeret, dicsér Úr téged.

Óhajtásim, könyörgésim, panaszim,/ nem taszitá Felséged el beszédim,/ de megnyitád szent füleid, örömim/megújítád elfeledvén büneim. ${ }^{537}$

\footnotetext{
${ }^{536}$ A különböző iskolák verstani álláspontjainak, az elnevezéseknek az ismertetése messzire vezetne a témánktól, így a metrumot a Papp Géza által a lengyel fordításoknál meghatározott terminusokkal nevezzük meg.

${ }^{537}$ A soráthajlások és a közölések itt is, szinte minden strófaszerkezet legjellemzőbb vonásai lesznek csakúgy, mint a lengyel fordításoknál.
} 
Rólad azért soha nem feledkezem,/ jótétedet nagy felszóval dicsérem,/ mindeneknek háladással beszélem, / Felségedet csak mind éltig szeretem.

Az Erős ellenségtől... kezdetű zsoltárban ugyanilyen gyakori a reflexió, a 7. strófája ebből áll:

Örök Atya Isten, halld meg füleiddel, / könyörgésemet vegyed te jó kedveddel,/ beszédimet fogjad meg figyelmességeddel,/ esedezésem, Uram, egyezzen kedveddel.

A közölések, soráthajlások, az anaphorisztikus, ismétlődéseken és szokatlan szórenden alapuló szerkesztésmód használatát és az Isten önreflexív módon történő dicsőítését is kiválóan szemlélteti az $A z$ Úristent az egész föld... kezdetű zsoltár. Első három strófájában mindenre bőven találunk példát:

Az Úristent az egész föld,/ szolgálja víg örömmel öt,/ jer, járuljunk eleibe,/ háládásban s éneklésben.

Már ismerjük istent, hogy Úr,/ kitől s' nem magától más Úr,/ ő népi és nyáji vagyunk,/ dicsérvén hozzá folyamjunk.

Énekkel s háládásokkal,/ szent nevét magasztalással, mert gyönyörüséges az Úr,/ mindörökké irgalmas Úr.

Az ismétlődő elemek és a soráthajlás olyan szervezőelv ezeknél a zsoltároknál is, hogy a szemléltetésre szinte korlátlanul hozhatnánk a példákat. Az ismétlés által egybefüzött, a strófahatárokon túl is folytatódó, soráthajlásokban gazdag gondolatmeneteket példázza a Nagy irgalmasságát... kezdetű zsoltár 5-6. strófája, mely egyazon kérdéskört tárgyalja két strófában: azt, hogy van-e az Istenhez hasonló erővel rendelkező entitás.

Lehet-e ugyanis mert valaki hasonló égben, s Istennek fiai közt parancsoló, mint Felséged? Uram, rettenetes vagy te, szentek közt állandó.

Igen rettenetes udvarló seregednél Uram, seregeknek Istene, vajon s' ki él, ki erös, mint te vagy? Mert környülled álló igazság örökké él. 
Az ismeretlen szerzőjü, csak unitárius korpuszon belül található néhány ének bemutatott poétikai jellemzői alapján láthatjuk, hogy az ismeretlen lengyel zsoltárfordító és az ezeket a szövegeket szerző zsoltáríró számtalan közös poétikai eljárást, retorikai, metrikai eljárást alkalmaz, s akrosztichonhasználatuk is hasonló. Ezek alapján talán érdemes azt gondolnunk, hogy a lengyel zsoltárok fordítója és a bemutatott énekek szerzője egy és ugyanazon, ám továbbra is ismeretlennek mondható személy lehetett.

\section{Balassi-hagyomány a korai nyomtatványokban és kéziratokban}

A dolgozat igyekezett bemutatni a protestáns gyülekezeti énekhagyományban megmutatkozó változási mintákat, azaz azt, hogy az egyes énekek annak ellenére, hogy nyomtatott kiadásokban is jelen vannak, milyen variabilitást mutatnak egymáshoz képest. Látható, hogy a 17. század elejére már egészen nagy különbségek észlelhetők a debreceni református, az evangélikus és az unitárius kiadások közötti szövegváltozatokban. A 17. század első harmadára már minden felekezet rendelkezett nyomtatott énekeskönyvvel, de az énekanyag nagyszámú egyezése mellett az énekek változatai arra utalnak, hogy a különböző felekezetek különböző variánsokat használnak, melyeket a gyülekezet szóbeli hagyománya és az énekeskönyvek szerkesztőinek munkája közösen alakított ki. A protestáns énekhagyomány e közköltészet felé tendáló, olykor markáns variabilitást mutató jellege mellett igyekeztünk hangsúlyt fektetni arra, hogy megmutassuk, az unitárius énekeskönyvek kiadásaiban - annak ellenére, hogy az az állítás teljesen igaz, miszerint az unitárius szöveghagyomány a leginkább eltérő a többi felekezetétől,- ugyanazok a változási tendenciák érvényesülnek, mint a további protestáns kiadásokban, így a hagyományba ezek is beilleszthetők.

A dolgozat utolsó fejezete a gyülekezeti énekhagyományba bekerülő szövegek változási tendenciáit egy olyan szövegcsoporton is megkíséreli bemutatni, amely elsők között (ha nem is legelőször) az unitárius gyülekezeti énekeskönyvekben jelenik meg nyomtatásban. A régi magyar irodalom legkedveltebb témájáról, Balassi Bálint költészetéről, azon belül az istenes témájú énekeiről lesz szó, s azoknak is a legkorábbi, még csupán egy-egy forrásban szórványosan előforduló szövegváltozatait igyekszünk alaposan megvizsgálni. 


\section{1. Az Istenes énekek hagyománya ${ }^{538}$}

Balassi Bálint és Rimay János istenes versei jó ideig együtt jelentek meg nyomtatásban, így az alapján, hogy a két szerző szövegei elkülönülnek-e egymástól, vagy sem, a kiadástörténet két típust különböztet meg: rendezetlen és rendezett kiadásokat. Rendezetlen kiadásoknak nevezzük azokat, amelyekben Balassi és Rimay szövegei együtt, Balassi neve alatt, a szerzők szövegeit összevegyítve jelennek meg. A rendezetlen kiadások jelenleg ismert első darabja 1632 körül Bártfán jelent meg. ${ }^{539}$ Ezt 1633-ban Bécsben követte egy kiadás, amelyről azonban feltételezhető, hogy nem került forgalomba. ${ }^{540}$

A rendezett kiadások alatt azokat az Istenes énekek kiadásokat értjük, amelyek a két szerző szövegeit már elkülönülve, és Rimay nevét is feltüntetve jelennek meg. Ebből az első kiadás az 1656 körüli ún. „váradi második” kiadás, melyet Szenci kertész Ábrahám jelentetett meg. Vadai István legújabb kutatásai szerint ${ }^{541}$ ebből a rendezett kiadásból származik az elveszett lőcsei kiadás, és a Szebenben 1666-ban Szenci Kertész által kiadott 1666-os kiadás, mely a kolozsvári típusú Istenes énekek kiadások ősének tekinthető.

Sinka Zsófia kutatásai az Istenes énekek szövegeinek kollációján alapulnak, s ő arra jut egy tanulmányában, hogy az Istenes énekek szövegváltozatait alaposan megvizsgálva „a versek szövegtörténete nem irható le az ismert stemmával." ${ }^{~} 42$ Sinka Zsófia ezt még Vadai friss eredményei elött mondja, de ettől függetlenül a szöveghagyományon továbbra is az látszik, hogy kötetszinten az Istenes énekek konkrét leszármazási ágrajzának elkészítése problematikus, hiszen a szövegek változataiban mindig vannak olyan eltérések, amelyek az

\footnotetext{
${ }^{538}$ Mivel a dolgozatunk szempontjából a nyomtatott Istenes énekek kiadások mellékesnek tekinthetők, így a szükséges mértékben ismertetjük azokat, de a részletes, igen nagy változékonyságot mutató szakirodalom széleskörü ismertetésétől eltekintünk, s igyekszünk csupán a legfrissebb, és a legelfogadottabb irodalmat ismertetni.

${ }^{539}$ H. HuBERT Gabriella, Balassi Istenes énekeinek legelsö kiadása? MKSz, 1995, 169-172.

${ }^{540}$ Armando NuZzO, Balassi népszerüsitésének kezdetei: a bécsi kiadás, ItK, 1992, 639-645. krúda - szócikk in: Magyar Müvelödéstörténeti Lexikon LX. minden kor, a föszerkesztö Köszeghy Péter hatvanadik születésnapjára, szerkesztette BARTÓK István, CsÖRSz Rumen István, JANKOVICS József, SzENTMÁRTONI SzABó Géza, Balassi Kiadó, Budapest 2011. 116-120. = Mikor jelent meg Balassi Bálint Istenes énekinek bécsi kiadása? (Egy 1991-es pécsi előadás megírt változata.)

${ }^{541}$ VADAI István, Balassi, Rimay és Szenci Kertész Ábrahám - Az Istenes énekek kiadástörténetének új modellje, előadás az MTA ITI Reneszánsz Osztályán, 2015. 02. 24-én, ugyanez az előadás elhangzott Szegeden, 2015.03. 3-án.

${ }^{542}$ SINKA Zsófia, Adalékok a Balassi-Rimay szöveghagyományhoz = Filológia és textológia a régi magyar irodalomban, szerk. KECSKEMÉTI Gábor, TASI Réka, Miskolci Egyetem BTK Magyar Nyelv- és Irodalomtudományi Intézet, Miskolc, 2012, 395.
} 
előző kiadásban nem voltak benne, de nem feltétlen tekinthetők a szerkesztő/kiadó rontásának, vagy éppen javításának. ${ }^{543}$

Bár a mi kutatásaink nem az Istenes énekek filológiájának tisztázására irányulnak, azt viszont merjük hangsúlyozni, hogy a korai, az Istenes énekek nyomtatása előttről fennmaradt csupán egy-két Balassi (és/vagy Rimay) verset tartalmazó nyomtatványok és kéziratok szöveghagyománya tulajdonképpen a későbbi Istenes énekek kiadások mindegyikétől nagyon távol áll. Olyan távol, hogy azt is kizárhatjuk, hogy egy esetleg eddig ismeretlen, mégis megjelent nyomtatványról, vagy egy kéziratos hagyományozódási ágról származnának fennmaradt forrásaink. A következőkben a korai fennmaradt források tükrében (csak az unitárius forrást részletezve) azt mondhatjuk, hogy ezek a szórványosan előforduló Balassi és Rimay versek több kéziratból származnak, nem egyből. ${ }^{544}$ Az Istenes énekek kiadásainak öröklődési modelljét Pap Balázs úgy mutatja be, hogy az Istenes énekek kiadásai egyrészt az autográfból származó kéziratos hagyományból és a szórványosan egy-egy nyomtatványban előforduló Balassi-versekből táplálkozik. ${ }^{545}$

Ezt a következőkben megkíséreljük azzal az állítással kiegészíteni, hogy az Istenes énekek nyomtatott kiadásai és a fennmaradt, szórványosan kéziratban és nyomtatványban előforduló Balassi-szövegeknek az általunk vizsgált, protestáns gyüjteményekben meglévő változatai nemigen mutatnak kapcsolatot egymással. Az egyes forrásokban található variánsok olyan távol állnak egymástól, hogy azok semmiképp nem eredhetnek egymásból, s mindeközben a szövegváltozatok állapota arra enged következtetni, hogy Balassi bizonyos istenes énekei már a 17. század elején a variabilitásnak, a gyülekezeti énekléssel járó változásoknak kitett, népszerü szövegek lehettek.

Állításunk tehát az, hogy ezek a 17. század eleji protestáns hagyományban megtalálható, ma ismert szövegváltozatok nem voltak hatással a későbbi Istenes énekek kiadások szövegváltozataira, s a 17. század eleji protestáns gyüjteményekben található szövegváltozatok eredetét nem egy autográf versgyüjteményre vezethetjük vissza. A szövegállapotokat nézve sokkal valószínűbb, hogy egy-egy vers „kikerült” a nyilvánosság elé, és az így kikerültek, tehát nem a gyüjtemények valamelyikében élők nagyon hamar népszerüek lettek. Ezek a népszerü, a gyülekezeti éneklés útján elindult változatok pedig olykor a nyomtatott gyülekezeti énekhagyományba is bekerültek.

\footnotetext{
${ }^{543}$ Erről szól Sinka Zsófia tanulmánya, példákkal szemléltetve az állítását. SiNKA Zsófia, i.m. 387-395.

${ }^{544}$ Már Vadai István említett előadásának utolsó diája is erről számol be, azaz azt mutatja be, hogy több kéziratos forrásból táplálkoztak az egyes hagyományok.

${ }^{545}$ PAP Balázs, i.m., 64-65.
} 
Úgy tünik, annak ellenére, hogy a 17. század első harmadában nem volt nyomtatott Istenes énekek kiadás, egyes szövegek mégis nagy népszerüségnek örvendtek. A népszerüség miatt a szövegek variálódtak, változtak, hiszen a „hivatalos” gyülekezeti énekgyüjtemények közül csupán az unitáriusok vették be, így jórészt kéziratosan hagyományozódtak. E nagyfokú variálódást az Istenes énekek kiadásai igyekeznek majd megakadályozni, s állandósítani próbálják a szövegeiket.

\section{2. Az Istenes énekek szövegcsoportjairól}

Klaniczay Tibor nagyívü tanulmánya óta ${ }^{546}$ az Istenes énekeknek három szövegcsoportját különböztetjük meg az egyes szövegcsoportok történetének különbözősége miatt. Az első csoportba azokat a szövegeket teszi Klaniczay, amelyek Szenci Kertész kötetének élén szerepelnek. Klaniczay szerint ezeket a rendezetlen kiadásokban jobb állapotban találjuk, mint Szenci Kertész rendezett kiadásában, mert új forrás híján a szövegeik csak romolhattak. ${ }^{547} \mathrm{~A}$ második csoportba a rendezett kiadásokban jobbnak tartható szövegek vannak, mert azok szerepelnek a korábbi rendezetlen kiadásokban, és az újonnan rendezett kiadásban is, új források ismeretében kiadva. A harmadik csoportot a Szenci Kertész-féle kiadások bővítményei képezik, vagyis azok a szövegek, amelyek korábban egy rendezetlen kiadásban sem jelentek meg, csupán ekkor, az első rendezett kiadásban.

A később kifejtendők miatt ezeket a csoportokat érdemes részletesen felsorolnunk is. ${ }^{548}$ A táblázat bemutatja a három csoport énekeit, és feltünteti, hogy melyik szerzóé a szöveg. Vastagon szedjük azokat a verseket, amelyek az Istenes énekek nyomtatott kiadása előtt is megtalálhatók voltak kéziratban vagy nyomtatványokban, s lábjegyzetben közöljük, hogy mely forrásban lelhetők fel. Mivel a fejezet elsődleges célja a Balassi-versek korai hagyományozódásának vizsgálata, a Rimay-versek közül csak azoknak említjük meg a forrását, amelyek az unitárius hagyományban, illetve az 1602-es debreceni énekeskönyvben megjelennek, tehát a 17. század eleji nyomtatott protestáns hagyomány részei.

\footnotetext{
${ }^{546}$ KLANICZAy Tibor, Hozzászólás Balassi és Rimay verseinek kritikai kiadásaihoz, MTA I. OK. 1957, $263-338$.

${ }^{547}$ Klaniczay hosszas érvelését lényegre töröen foglalja össze Sinka Zsófia idézett tanulmánya, így egy újabb összefoglalás helyett a továbbiakban SinKA Zsófiát idézem. (i.m., 388-89.)

${ }^{548}$ Az egyes csoportok verseit Sinka Zsófia alapján közlöm. (i.m., 389-390.)
} 


\section{I. csoport:}

\begin{tabular}{|c|c|}
\hline Balassi & Rimay \\
\hline Bizonnyal esmérem... ${ }^{549}$ & Ó, szegény megromlott... \\
\hline Ó, én Istenem... & Epicédium versei \\
\hline Ó, szent Isten, kit kedvedben... & Mert ki megtér... \\
\hline Kegyelmes Isten, kinek... 550 & \\
\hline Adj már csendességet... 551 & \\
\hline Lelkemnek hozzád való... ${ }^{552}$ & \\
\hline ó, én kegyelmes Istenem... ${ }^{553}$ & \\
\hline Végtelen irgalmú... 554 & \\
\hline
\end{tabular}

\section{II. csoport:}

\begin{tabular}{|c|c|}
\hline Balassi & Rimay \\
\hline Bocsásd meg, Úristen... & Világon, ég alatt... $^{555}$ \\
\hline A Szentháromságnak elsö... & Legyen jó idö csak... $^{557}$ \\
\hline
\end{tabular}

${ }^{549}$ Tatrosy György-énekeskönyv, S 37, 1618 körül.

${ }^{550}$ Kassai István énekgyüjteménye, unitárius, S 1009; (H 32,) 1629 körül.

551 Kéziratos forrásai: Vasady-kódex, 1613-15, S 27; Kassai István énekgyüjteménye, H 32, 1629 k. Nyomtatványban: RMNy 983. 1602-15, a kolozsvári unitárius énekeskönyv; RMNy 1290, a kolozsvári unitárius magánhasználatra szánt énekeskönyv elveszett kiadása; RMNy 1541. Az 1632-es unitárius gyülekezeti énekeskönyv.

552 Tholnay Ferenc-énekeskönyv, 1614-1621, S 29.

${ }^{553}$ Kéziratos forrásai: Detsi-kódex, 1609-13, S 25; Lipcsei-kódex, 1615, S32; Lugossy-kódex, 1629-35, S 47. Nyomtatványban, nótajelzésként szerepel még a szöveges nyomtatott megjelenés előtt: RMNy 983. Az 1602-15 közé tett kolozsvári unitárius énekeskönyv két Kochanowski-fordítása a Nota Polinica nótajelzés mellett nótaként említi. Ezek az Ím, s hogy kiált... és a Reménységem vagy Istenem ... kezdetűek.

${ }^{554}$ RMNy 945, Keresztyéni imádságos könyv, Graz, 1606; RMNy 787, Generosi ac magnifici, Vizsoly, 1596; RMNy 976, Keresztyéni és istenes... Bártfa, 1609; RMNy 1003, Keresztyén imádságos könyv, Pozsony, 1610; RMNy 1345, Imádságos könyv, Pozsony, 1625; RMNy 1442, Keresztyéni istenes és... Lőcse 1629; RMNy 1513, Imádságos könyv, Pozsony, 1631. (Ez a szöveg nem fordul elő unitárius hagyományban, így ezt a későbbiekben nem részletezzük.)

${ }^{555}$ Kéziratos forrásai: Bölöni-kódex, 1615-21, S 30; Lipcsei-kódex, 1615, S 32; Kuun-kódex, 1621-1647 S 40. Nyomtatott forrásai: RMNy 962, Psalterium Ungaricum, 1607, Herborn (az előszóban egy versszak idézve); RMNy 983, az 1602-15 közötti unitárius énekeskönyv, RMNy 1037, Szent Biblia, Oppenheim, 1612; RMNy 1290, az elveszett 1623-as kolozsvári unitárius magánhasználatra szánt énekeskönyv, RMNy 1422, A Jézus szivét szeretö... Bécs, 1629. RMNy 1541. Az 1632-es unitárius gyülekezeti énekeskönyv.

556 Megvan az Erdödy-énekeskönyvben, H 606. A gyüjteményben több Rimay-vers is szerepel a Balassiszövegeken kívül. Mivel az alaposabban vizsgált szövegcsoportnak az Erdödy-énekeskönyv darabjai nem képezik a részét, így az énekeskönyv részletezésétől eltekintünk. Bővebben: SzELESTEI N. László, Az Erdődyénekeskönyv, ItK, 1978, 83-94. (A későbbiekben látjuk, hogy mely szövegekre fogjuk a hangsúlyt helyezni. Az unitárius hagyomány szempontjából a Szentháromságról szóló Balassi-vers értelemszerűen nem is jöhet szóba a dogmatikai okok miatt.) 


\begin{tabular}{|c|c|}
\hline A Szentháromságnak, kinek... ${ }^{558}$ & Ó, ki késön futok...559 \\
\hline A Szentháromságnak harmadik... ${ }^{560}$ & Az Úr az égben... \\
\hline Nincs már hová lennem... & Ó, kegyelmes Isten... \\
\hline Az én jó Istenem... & Jöjj mellém, szent Isten ... \\
\hline A te nagy nevedért... & Egyedül tebenned... \\
\hline Mint a szomjú szarvas... & Nem lehet szebb dolog... \\
\hline Mennyei seregek... ${ }^{561}$ & Könyörülj énrajtam... \\
\hline Áldj meg minket, Úristen... & Kiáltok hozzád mélységböl... \\
\hline Segélj meg engemet... & Reménységem te légy nékem... \\
\hline \multirow[t]{9}{*}{ Vitézek, mi lehet... } & Örök életnek... \\
\hline & Boldog, kinek vétkét... \\
\hline & Hivek, keresztyének... \\
\hline & Ó, Uram Isten... \\
\hline & Vitézség embernek... \\
\hline & Virtus, lelki jóság... \\
\hline & Kerekded e világ... \\
\hline & Udvar s irigy tisztek... \\
\hline & Katonák hadnagya... \\
\hline
\end{tabular}

\section{III. csoport:}

\begin{tabular}{|c|c|}
\hline Balassi & Rimay \\
\hline Áldott szép pünkösdnek ... & Miként a szép napnak... \\
\hline Pusztában zsidókat... ${ }^{562}$ & Ez világ mint egy kert... \\
\hline
\end{tabular}

\footnotetext{
${ }^{557}$ Megvolt az RMNy 1290-ben, a mára elveszett 1623-as unitárius magánhasználatra szánt énekeskönyvben. Érdekes, hogy a magánhasználatra szánt unitárius kiadások vélhetően mindegyikében megvan, nem tartalmazza viszont egyik gyülekezeti énekeskönyv sem. Feltehetően csak magánhasználatra szánják.

${ }^{558}$ Megvan az Erdödy-énekeskönyvben, H 606.

${ }^{559}$ Megvolt az RMNy 1290-ben, a mára elveszett 1623-as unitárius magánhasználatra szánt énekeskönyvben. Az RMNy 1541. ezt sem tartalmazza.

${ }^{560}$ Megvan az Erdődy-énekeskönyvben, H 606.

${ }^{561}$ Megvan az Erdődy-énekeskönyvben, H 606.

${ }^{562}$ Kéziratos: Kuun-kódex, S 40, 1621-1647, Nyomtatvány: RMNy 983. Az 1602-15 közötti kolozsvári unitárius énekeskönyv; RMNy 1290. Az 1623-as elveszett kolozsvári unitárius magánhasználatra szánt énekeskönyv, RMNy 1541. Az 1632-es unitárius gyülekezeti énekeskönyv. Valószínúleg megvolt az 1635-ös, makulatúrában fennmaradt (RMNy 1615) unitárius kiadásban is, hiszen a kiadvány fennmaradt anyaga pontosan egyezik az 1623-as énekeskönyv incipitjegyzékével, és az 1700-as későbbi magánhasználatra szánt unitárius énekeskönyvével.
} 


\begin{tabular}{|l|c|}
\hline Ó, én édes hazám... & Hitetö szerencse... \\
\hline & Senkit a pénz... \\
\hline & Kinek tegyek panaszt... \\
\hline & Kedvezö szemeddel... \\
\hline & Enyhitsd meg, Uristen ... \\
\hline & Hogy feledkeztél el... \\
\hline & Ha az isten nékem... \\
\hline & Tarts meg, Uram, engem... \\
\hline & A jó hitü ember... \\
\hline & Kegyes Jehova ... \\
\hline & Nincsen segítségem... \\
\hline & Igaz általút... \\
\hline & Minden dolgok között... \\
\hline & Szüz Mária lakozván... \\
\hline & Mi Urunk, s édes Atyánk... \\
\hline & Adjunk hálát Istenünknek... \\
\hline & Az idö ósága ... \\
\hline
\end{tabular}

A táblázatból is jól kivehető, hogy az Istenes énekek kiadásai előtt már mind a három csoportból kinyomtattak bizonyos énekeket, s emellett terjedtek kéziratosan is.

Ebből kitetszik, hogy a 17. század első harmadában, az Istenes énekek megjelenése előtt már azok a szövegek is terjedtek különböző nyomtatott és kéziratos hordozókon, amelyek legelőször együtt csak a 17. század második felében jelennek meg az Istenes énekekben.

Ebböl persze még nem következik feltétlen az, hogy Balassi szövegei az Istenes énekek megjelenése elött nem voltak összegyüjtve, de nem zárhatjuk ki ezt sem.

Először érdemes körbejárni azt a feltevést, hogy a Balassi-korpusz már össze volt gyűjtve, és a szórványosan megjelenő énekek ilyen, Balassi összes versét tartalmazó kötetből lettek beválogatva a különböző nyomtatott és kéziratos, a 17. század első harmadából származó gyüjteményekbe.

Számos tanulmány született arról, hogy Balassi Bálint 1589 őszén elkezdte a Maga kezével irt könyvének anyagát összegyüjteni és összeállítani. ${ }^{564}$ Balassi Maga kezével írt 
könyve nem maradt ránk, de a kötetkompozícióba feltételezett 33 darabot tartalmazó vallásos tematikájú szövegeiből csak 10 volt készen a Balassa-kódex tanúsága szerint. ${ }^{565}$ Ezt nevezi a szakma Más könyvnek, melynek meglétéről, tartalmáról is számos elmélet született, ezek részletezésében nem megyünk bele. A Balassa-kódexnek a 10 vallásos énekről szóló részét azért kell viszont feltehetően létezőnek tekintenünk, mert a kódex valószínü, hogy a Maga kezével irt könyvről készült másolatának a másolata. Ez a sokat idézett rész nem tisztázott, hogy mikor kerülhet bele a Balassi-Rimay összegyüjtött kéziratos hagyományba. ${ }^{566}$ Azt viszont Klaniczay tanulmánya óta tudjuk, hogy a Balassa-kódex másolója egy 1610 körül keletkezett kéziratból dolgozhat. ${ }^{567} \mathrm{Az} 1610$ körüli másoló személyét Vadai István megkíséreli azonosítani is, s a „művelt irodalomkedvelő férfiút” Petki János személyében véli megtalálni. ${ }^{568}$ Petki Jánosról meg kell jegyeznünk, - ez a későbbiekben még említésre kerül hogy erdélyi kancellár, unitárius vallású, és barátság füzi Péchi Simonhoz és a szintén versíró Kátai Mihályhoz. (Kátai Mihály Magas mennyben lakozó... kezdetű éneke egyébként éppen az 1602-15 közötti unitárius énekeskönyvben jelenik meg nyomtatásban, s kéziratos forrása is alig van: az Alciatus-toldalékban és a Lipcsei-kódexben maradt fönn. ${ }^{569}$ )

Az 1632-es bártfai első, rendezetlen kiadást nem tarthatjuk a kezünkbe, de a rendezetlen kiadások Balassi-verseit ismerjük. Már ebből is kitünik, (ld. a táblázatot) hogy hány Balassi-szöveg nem volt meg a rendezetlen kiadások elött sem kéziratos, sem nyomtatott formában. Példaként említjük a Pusztában zsidókat... (RPHA 1186), mely az Istenes énekek darabjaként csak az 1650-es években jelenik meg nyomtatásban, illetve a Balassa-kódexbe is bekerül, de már megvan előtte több unitárius nyomtatványban (ld. a táblázat lábjegyzetében) és a Kuun-kódexben is szerepel. Így továbbra sincs arra adatunk, hogy az Istenes énekek a nyomtatott megjelenés előtt egyben, összegyüjtve, akár nyomtatott, akár kéziratos formában

\footnotetext{
${ }^{564} \mathrm{~A}$ Maga kezével irt könyv lehetséges szerkezetéről, koncepcióiról legelöször Horváth Iván írt, (HoRVÁTH IváN, Balassi költészete történeti poétikai megközelitésben, Bp., Akadémiai, 1982) amely vitákat váltott ki, melyek a különféle a Maga kezével írt könyv koncepcióját különbözöképp képzelik el. Mivel ez a témánktól messzire vezetne, így a viták ismertetésétől eltekintünk. KöszEGHY Péter, Horváth Iván: Balassi költészete történeti poétikai megközelitésben, ItK 1987-88. 310- 338. HoRVÁTH Iván, Egy vita elháritása, ItK, 1987-88, 642-665; KöSZEGHY Péter, Elháritva (Megjegyzések Horváth Iván: Egy vita elháritása címü cikkéhez), ItK, 1989, 597-604.

${ }^{565}$ Balassa-kódex, közzéteszi KöSzEghY Péter, betűhủ kiadás VADAI István, Bp., Balassi Kiadó, 1994. 99. (Idézem a saját modernizált átiratomban: „Még vannak egynéhány Istenhez való énekek, kiket a psalmusokból is, magától is szerzett, ki mindenestöl is tíz, azok más könyvben vannak, nem is adja azokat ki, meddig több psalmus nem fordít meg azokhoz. Azért evilági éneket a Jephtes históriájától elválva, ki még nem kész.") Az idézetből az tűnik tehát ki, hogy a vallásos tematikájú könyvei más könyvben vannak, és még nem adja ki Balassi azokat, hiszen még szándékozik a tíz vallásos ének mellé többet is fordítani.

566 Vadai István például a 99. lap bejegyzését azzal magyarázza, hogy nyomtatásból ismerhették ezeket az énekeket. (VADA István, Hozzászólás a Hozzászóláshoz = A szerelem költoöi, Bp., Universitas, 2007, 146.)

${ }^{567}$ KlaniCZAY, i.m., 282.

568 VADAI, i.m., 160 .

${ }^{569}$ A Lipcsei-kódex két Balassi-verset is öriz, 1615-ös másolatban.
} 
nagyobb ismertségre tehettek volna szert, mert a rendezett és rendezetlen kiadások énekanyagából számos nem jelenik meg más forrásban korábban, olyan szöveg viszont, amely csak a rendezett kiadásokba kerül be (Pusztában zsidókat...) már megjelenik korábban is nyomtatásban.

Ha létezett is a Más könyv, nagyjából tíz énekkel, akkor sem kerülhetett ki abból a táblázatban felsorolt, a 17. század első harmadában már kéziratos vagy nyomtatott formában ismert kb. 21 Balassi-ének.

Így jöhet szóba a terjedés szempontjából egy másik lehetséges opció, miszerint nem egy gyüjtemény volt népszerü, hanem külön-külön, kisebb csoportokban terjedtek Balassi istenes témájú énekei.

Ezt az állítást, hogy a teljes istenes tematikájú Balassi-korpusz nem volt még összeszedve, de legalább is népszerüsítve az 1630-as évekig, több külső, nem az énekhagyományból eredő forrás is alátámasztja. Maga Rimay idéz egy Balassi-levelet a tervezett előszavában, ${ }^{570}$ amelyet Balassi Braunsbergből, Lengyelországból írt, és amelyben arról panaszkodik, hogy verseit sokan ,ízetlenítik”, megváltoztatják, elrontják. ${ }^{571}$

„S nevetem azokat, s búsulás nélkül nem szenvedhetem, akik akármi írásimot is elméjeknek csomós pórázára kötvén, sok igéknek változtatásával (obruálván sesusit is) vesztegetik, fesletik, izetlenítik, és azmellett engem való rágalmazásokkal nyelveknek hegyeit is fenik." 572

\section{2. 1. Kitérés: Balassi és a lengyelek}

Az ebben a levélben Rimay jóvoltából fennmaradt idézetből egyébként az is kiderül, amellett, hogy a Balassi-verseket mind szavaiban, mind jelentésükben sokan megváltoztatják, s ez a változtatás negatív hatású a szerző szerint - hogy három ,énekecskét” küld Lengyelországból Balassi Rimayinak. A három ,énekecske” közül az egyiket Eckhardt Sándor a Nincs már hová lennem... kezdetüben véli felfedezni, annak nótajelzése és rövidsége

\footnotetext{
${ }^{570}$ Rimay János Balassival kapcsolatos állításait mindig körültekintéssel kell kezelnünk, de mivel ebben az esetben egy levelet idéz, illetve mivel Balassi a Komédia kapcsán is kitér arra, hogy a versszerzést akár el is vehetik tőle, $\mathrm{s}$ mások versszerzési szokásait kritizálja, a Rimay által idézett Balassi véleményt talán nem tarthatjuk teljesen alaptalannak.

${ }^{571}$ Noha jelenlegi ismereteink szerint Balassi istenes énekei nem voltak ismertek a 16. század végén, $\mathrm{s}$ egy forrás sem tudósít bennünket ezekről konkrétan, mégsem zárhatjuk ki, hogy a feltehetően itt, ekkor, Lengyelországban keletkezett istenes témájú Balassi-szövegekre is vonatkozhat az idézet.

${ }^{572}$ Rimay János írásai, utószó, szöveggondozás és jegyzet Ács PÁL, Bp., Balassi, 1992, 51.
} 
miatt. ${ }^{573}$ Az 1590 körül Lengyelországban keletkezett versei kapcsán Jan Slaski kiemeli, hogy Kochanowski hatása igen valószínünek tünik Balassi ezen, ekkoriban keletkezett szövegeiben. ${ }^{574}$ Ezt a képet árnyalja tovább Balázs Mihály, aki tanulmányában elsősorban Balassi korai darabjain mutatja be a lengyel hatást, s föképp Kochanowski hatását. ${ }^{575}$ Ehhez csak azt az apró észrevételt kívánjuk felmutatni, hogy éppen az 1590-es években Lengyelországban szerzett énekek olyanok, amelyek a magyar Kochanowski-fordításokkal poétikai értelemben több szempontból - metrum, ${ }^{576}$ a versekben megjelenő folyamatos, halmozott reflexió ${ }^{577}$ a személyes istendicséretre (könyörgés, dicsérés, magasztalás stb.), soráthajlás és közölés ${ }^{578}$ - hasonlóságot mutat. Az ezekre az évekre datált Balssi-versek közül kettő ugyanúgy Amen-nel is végződik, mint az unitárius magyar fordítások. (Ó, én kegyelmes Istenem... és a Nincs már hová lennem...) A Kegyelmes Isten... pedig olyan Balassi-vers, amely a kolofonja szerint 1591-ben az „óceánum” mellett - feltehetően Lengyelországban szereztetett.

Térjünk vissza arra, hogy Balassi szövegei feltehetően nem egy gyüjteményben hagyományozódtak az Istenes énekek kiadása előtt, mely mára elveszett, hanem a gyüjtemény létrehozása előtt, néhány darabja nyilvánosságra kerülhetett, s ezeket énekelni kezdték, így szövegei erős változáson mehettek keresztül. Láttuk, hogy a Rimay által idézett Balassi-levél erről a változtató tendenciáról már panaszos hangvételben szól. ${ }^{579}$

Az, hogy Balassi szövegei - és itt jeleznünk kell, hogy nem tudhatjuk, az istenes tematikájúakról, vagy az összesről van-e szó - nem voltak összegyüjtve, s még Rimaynál sem voltak meg teljesen, egy Ötvös Péter által ismertetett Rimay-levélből is kiderül. ${ }^{580}$ Rimay ebben azt írja 1629-ben, hogy egy tervezett nyomtatott kiadáshoz igyekszik összegyüjteni Balassi verseit.

\footnotetext{
${ }^{573}$ ECKHARDT Sándor, Balassi Bálint összes müvei I, Budapest, Akadémiai, 1951. 89. sz., jegyzete: 268.

574 Jan SLASKI, Balassi Bálint és a lengyelek, ItK, 1999, 655-660.

${ }^{575}$ BALÁzs Mihály, i.m. (Tiszatáj)

${ }^{576} \mathrm{Az}$ Ó, én kegyelmes Istenem... is a lengyel költészet legkedveltebb, a8 a8 a8 a8-as metrumában íródott csakúgy, mint a bizonyítottan (ld. föleg Balázs Mihály i.m.) lengyel forrású Áldj meg minket, Úristen... kezdetű vers.

${ }^{577}$ Kiért dicsérhessen lelkem mindenképpen... - Nincs már hová lennem; Hogy mind holtomig szívem legyen víg, téged magasztalván,/ Mindenek elött s mindendek fölött szent nevedet áldván. - Kegyelmes Isten...; Kiért az míg élek itten,/ Dicsérlek felséges Isten,/ ki könyörülsz ily veszetten,/Áldott légy örökké, Amen. - Ó, én kegyelmes Istenem...

${ }^{578}$ pl.: Csak rút szégyentül ódd fejemet, ha bántod... - Nincs már hová lennem...; Legyen azért elég immár/ sok búm, és szenvedtem nagy kár, Irút szégyen, ki mint heves ár/ lelkemben keservesen jár. - Ó, én kegyelmes istenem...

${ }^{579}$ A panasz mellett az esetleges lengyel hatású szövegek említése kapcsán érdemes azt is megjegyeznünk, hogy Rimay levélidézete említ három elküldött énekecskét is. Eckhardt Sándor (BÖM, 380) pont a fent idézett verseket sejti a három elküldött ,énekecske" mögött.

580 ÖTVÖs Péter, Rimay Balassi-kiadásának tervéhez, Egy meg nem kapott levél, ItK, 1990, 81-87.
} 
Szenci Kertész Ábrahám, az Istenes énekek rendezett kiadásának készítője már a Solvirogram Pannonius által elkészített, rendezetlen kiadások kapcsán panaszkodik a Balassi és Rimay-szövegek filológiai pontatlanságairól azt sérelmezve, hogy Solvirogram „alig tudhatott (avagy ugyan nem is) " ${ }^{, 581}$ különbséget tenni Rimay és Balassi szövegei között.

Ezt a szöveghelyet, és a többi, idézett explicit reflexiót Szilasi László ${ }^{582}$ Thienemann Tivadar $^{583}$ nyomán értelmezi is. Szilasi kifejti, hogy a fennmaradt adatok fényében úgy tűnik, Balassi és Rimay versei többféle módon hagyományozódtak. Egyrészt volt a kéziratosságon alapuló, Thienemann fogalmaival élve alakuló szövegcsoport, másrészt pedig igény jelentkezett ezek összeszedésére, rendszerezésére, filológiai helyretételére és kinyomtatására, hogy a nyomtatott szöveg (feltételezett) állandóságának igényét kielégítsék. ${ }^{584}$

Ezek fényében viszont érdemes Szilasival Vadai István azon állítását módosítani, hogy „Balassi verseinek nem voltak szerzői gyüjteményei, csak a szerzői gyüjteményének egyetlen másolata terjesztette el ezeket a verseket." ${ }^{585}$ Szilasi elemzése az itt ismertetett szövegek alapján arra jut, hogy az egyvonalú leszármazási ágnak ezek a reflexív explicit kortárs kijelentések ellentmondani látszanak, s ezzel úgy tünik, egyet kell értenünk. ${ }^{586}$

$\mathrm{Az}$ Istenes énekek nyomtatott megjelenése előtti kéziratos (és néhol nyomtatott) forrásban található Balassi-szövegek úgy tünik, nem Balassi összes versét tartalmazó gyűjteményekből származnak. Láthattuk, hogy Solvirogram nem tudja különválasztani Rimay és Balassi szövegeit, ami miatt Szenci Kertész Ábrahám újabb gyüjtőmunkába, filológiai rendezésbe kezd. Ezen kívül Rimay is azt írja a levelében, hogy össze kellene szedni Balassi szövegeit, és annak egy része a levél jelenének idején, 1629 nyarán „idegen kezekben” forog. ${ }^{587} \mathrm{~S}$ nem szabad elfeledkeznünk arról sem, hogy Balassi maga is panaszkodik 1591ben, hogy a verseit mennyire megváltoztatják.

Ha volt is tehát összegyüjtött Más könyv, avagy összegyüjtött teljes Balassi, az semmiképp nem lehetett ismert, nyilvános gyüjtemény - gondoljunk Rimay levelére. A szórványosan a nyomtatott és kéziratban hagyományozódó Balassi-szövegek a 17. század elején minden valószínűséggel nem egy gyüjteményből kerülnek el mindenhová, hanem kisebb csoportokban hagyományozódnak.

\footnotetext{
${ }^{581}$ Balassi Bálint és Rimay János Istenes énekei, szerk. SzABÓ Géza, Bp., Helikon, 1983, 22-23.

${ }^{582}$ SzILASI László, A sas és az apró madarak, Balassi Bálint költői nyelvének utóélete a XVII. század elsö harmadában, Bp., Balassi, 2008, 29 (Humanizmus és reformáció 30).

583 ThiEnEMANn Tivadar, Irodalomtörténeti alapfogalmak, Pécs, Danubia, 1931.

${ }^{584}$ SZILASI, i.m., 29.

585 VADAI István, Balassi Bálint fajtalan éneki, ItK, 1994, 673- 681. Idézi SzILASI László i.m. 27.

${ }^{586}$ SzILASI László, i.m., 27-28.

587 ÖTVÖs Péter, i.m., 85.
} 
Ezek a kisebb, néhány darabból álló Balassi-corpusok pedig olyan forrásokban fellelhetők, amelyeknek csak egy része köthető a protestáns gyülekezeti énekhagyományhoz. A továbbiakban ezekről lesz szó.

\section{3. A korai istenes témájú Balassi-szövegek néhány forrásáról}

Jelen fejezetben elsősorban az unitárius gyülekezeti énekléshez köthető forrásokról, s mellettük néhány protestáns forrásról lesz szó csupán, melyek Balassi-szöveget tartalmaznak, de nem tartjuk feleslegesen táblázatosan bemutatni a Balassi-szövegek 17. század eleji, források szerint rendszerezett táblázatát sem. ${ }^{588}$ A táblázatban a Végtelen irgalmú... kezdetü ének forrásait - mivel az a vizsgált anyag részét nem képezi, - csak nyomtatásban, egy viszonylag zárt corpusban maradt fönn - nem tüntetjük fel.

\begin{tabular}{|c|c|}
\hline Forrás & A forrásban található Balassi-vers \\
\hline $\begin{array}{c}\text { Tatrosy György-énekeskönyv, S 37, } \\
1618 \text { körül }\end{array}$ & $\begin{array}{l}\text { Bizonnyal esmérem rajtam nagy } \\
\text { haragod... }\end{array}$ \\
\hline $\begin{array}{c}\text { Kassai István énekgyüjteménye H 32, } \\
1629\end{array}$ & $\begin{array}{l}\text { Kegyelmes Isten, kinek... } \\
\text { Adj már csendességet... }\end{array}$ \\
\hline $\begin{array}{l}\text { Vasady-kódex, S 27, 1613-15, } \\
\text { megsemmisült }\end{array}$ & Adj már csendességet... \\
\hline $\begin{array}{l}\text { RMNy 983. Az 1602-15 közötti } \\
\text { kolozsvári unitárius énekeskönyv }\end{array}$ & $\begin{array}{l}\text { Adj már csendességet... } \\
\text { Nótajelzésként két lengyel } \\
\text { zsoltárfordításnál (Ím, s hogy kiált..., } \\
\text { Reménységem vagy istenem ....) : O, én } \\
\text { kegyelmes Istenem... } \\
\text { Bocsásd meg, Úristen... } \\
\text { Pusztában zsidókat... }\end{array}$ \\
\hline RMNy 1290. Az 1623-as unitárius & Adj már csendességet... \\
\hline
\end{tabular}

${ }^{588}$ Igaz, hogy Kőszeghy Péter készített hasonló táblázatot, de mivel ő a nyomtatásban megjelent szövegekkel nem foglalkozik, a kéziratos szerelmi tárgyú versekkel viszont igen, így a különböző szempontok miatt egy az ő táblázatához hasonló, tartalmilag mégis módosult változatot igyekszünk bemutatni. KöszEGHY Péter, Balassi Bálint, Magyar Amphión, Bp., Balassi, 2014, 200-201. 


\begin{tabular}{|c|c|}
\hline magánhasználatra szánt énekeskönyv & $\begin{array}{l}\text { Bocsásd meg, Úristen... } \\
\text { Pusztában zsidókat... }\end{array}$ \\
\hline $\begin{array}{l}\text { RMNy 1541. Az 1632-es unitárius } \\
\text { gyülekezeti énekeskönyv }\end{array}$ & $\begin{array}{l}\text { Adj már csendességet... } \\
\text { Bocsásd meg, Úristen... } \\
\text { Pusztában zsidókat... }\end{array}$ \\
\hline $\begin{array}{l}\text { Tholnay Ferenc-énekeskönyv, S } 29 \\
\text { 1614-21. }\end{array}$ & Lelkemnek hozzád való... \\
\hline Detsi-kódex, S 25, 1609-13. & Ó, én kegyelmes Istenem... \\
\hline Lipcsei-kódex, S 32, 1615. & $\begin{array}{l}\text { Ó, én kegyelmes Istenem... } \\
\text { Bocsásd meg, Úristen... }\end{array}$ \\
\hline Lugossy-kódex, S 47 1629-35. & Ó, én kegyelmes Istenem... \\
\hline Bölöni-kódex, S 30, 1615-21. & Bocsásd meg, Úristen... \\
\hline Kuun-kódex, S 40, 1621-40. & $\begin{array}{l}\text { Bocsásd meg, Úristen... } \\
\text { Pusztában zsidókat... }\end{array}$ \\
\hline $\begin{array}{l}\text { RMNy 962. Psalterium Ungaricum, } \\
\text { 1607, Herborn, előszó }\end{array}$ & Bocsásd meg, Úristen... \\
\hline $\begin{array}{l}\text { RMNy 1037, Szent Biblia, } \\
\text { Oppenheim, } 1612 .\end{array}$ & Bocsásd meg, Úristen... \\
\hline $\begin{array}{c}\text { RMNy 1422. A Jézus szivét szeretö... } \\
\text { Bécs, } 1629 .\end{array}$ & Bocsásd meg, Úristen ... \\
\hline Erdödy-énekeskönyv H 606. & $\begin{array}{l}\text { A Szentháromságnak elsö.... } \\
\text { A Szentháromságnak, kinek... } \\
\text { A Szentháromságnak harmadik... } \\
\text { Mennyei seregek... }\end{array}$ \\
\hline
\end{tabular}

Ha az unitárius nyomtatott hagyományt vesszük alapul, a legfontosabb források azok lesznek, amelyekben megvan az unitárius énekeskönyvben is megtalálható három Balassivers.

A Kuun-kódexben (S 40) a három Balassi-versböl kettő, a Pusztában zsidókat... és a Bocsásd meg, Úristen... található meg. Ez a forrás az általunk vizsgált korpusztól abban a tekintetben eltérni látszik, hogy ezen a két Balassi-szövegen kívül egy Rimay (Ó, ki későn) és több olyan ének is bekerült ebbe a gyüjteménybe, amely később, az Istenes énekek vegyes énekrendjében szerepelni fog majd. Éppen ezért ez egy olyan forrásnak tekinthető, amely a 
nyomtatott Istenes énekek kiadás elött számos közös ponton érintkezik az Istenes énekek szövegeivel incipit tekintetében, noha a szövegváltozatai erősen eltérnek bármely Istenes énekek kiadásétól. A gyüjtemény csak két Balassi-szöveget tartalmaz, s ebböl az egyik, a Pusztában zsidókat... olyan szöveg, amely Klaniczay III. csoportjában található meg, tehát legelöször az Istenes énekek darabjaként csak a rendezett kiadásokban jelenik meg. Ugyanez a helyzet az Ó ki későn... kezdetű Rimay-verssel is: az Istenes énekekben csak a rendezett kiadások során kerül be. Meg kell viszont jegyezni, hogy a Kuun-kódexben több olyan gyülekezeti ének van, mely a nyomtatott unitárius hagyománynak része, s emellett a két Balassi, s az egy Rimay-szöveg is olyan, amelyek nyomtatásban a Kuun-kódex előtt csak a kolozsvári unitárius énekeskönyvekben voltak meg. Magától értetődőnek tủnne azt mondani, hogy esetleg a kódex ezekből a forrásokból, vagy ezeknek a nyomtatványoknak a kéziratos hagyományából merít, ám - ahogy azt a Balassi-szövegek összevetésénél látni fogjuk - a szövegváltozatok olyan eltérők a nyomtatott unitárius hagyományban és a Kuun-kódexben, hogy ezeket egy forrásra visszavezetni, vagy az egymásból származtatást kimutatni lehetetlen. Semmi olyan textológiai és filológiai érvünk nincs, amelyből a két gyüjtemény szövegváltozatainak bármiféle kapcsolatára következtethetnénk. A Kuun-kódex és az Istenes énekek szöveghagyománya úgy tünik, érdemes az alaposabb összevetésre, de a dolgozat témája miatt ezt most nem kíséreljük meg, hiszen messzire vezetne. ${ }^{589}$

Kassai István énekgyüjteményéről a dolgozat elején, a felhasznált források ismertetésénél már volt szó. Ez az elsősorban a nyomtatott unitárius gyülekezeti énekeskönyv énekanyagát dogmatikai szempontból is unitárius változatban hozó gyüjtemény az 1629-es ex libris szerint Kassai Istváné volt, s Korzenszky Richárd érvelése ${ }^{590}$ alapján egy Makai Mihály nevü íródeák másolta. A tulajdonos Kassai István az erdélyi kancelláriát vezeti Kovacsóczy halálától, 1634-től 1644-ig. Kemény János fejedelem önéletírásában Kassai Istvánt igen kellemetlen emberként említi, de az előléptetését Péchi Simon kancellár életútjához hasonlítja. ${ }^{591}$ A tulajdonos tehát Péchi Simonhoz és Petki Jánoshoz [!], - ahhoz a Petki Jánoshoz, aki Vadai szerint esetleg az 1610 körüli Balassi-másoló lehet - hasonlóan erdélyi kancellár. Az unitárius források viszonylag gazdag (a többi felekezethez képest mindenképp

\footnotetext{
${ }^{589}$ Az incipitek alapján feltételezett énekegyezés, ahogyan azt a dolgozat elején láttuk, sok esetben félrevezető is lehet. Hiszen láttuk, hogy az 1593-as bártfai gyülekezeti énekeskönyv és az 1602-15 közötti unitárius énekeskönyv rengeteg közös éneket tartalmaz, a szövegek textológiai vizsgálata viszont kimutatja, hogy nem egymásból származnak a variánsok, mert azok rengeteg eltérést tartalmaznak. Néhány, nem teljes körü szövegösszevetés alapján mondhatjuk, hogy a Kuun-kódex a nagyszámú énekegyezés ellenére nem valamely Istenes énekek kiadás forrásából merít, csupán hasonló szövegeket válogat össze.

${ }^{590}$ KORZENSZKY Richárd, Kassai István énekgyüjteménye, Pannonhalma, 1997, 18-19.

591 KeMÉNy János, Önéletírása, kiad. SZALAY László, Pest, 1856, 407. A szóban forgó részt érvei alátámasztására KORZENSZKY idézi: i.m. 17.
} 
annak mondható) Balassi-anyaga nem zárja ki, hogy esetleg egy Petkihez hasonló, befolyásos kolozsvári személy által kerüljön ki néhány szöveg a gyülekezeti éneklésbe.

Kassai énekgyüjteményében Balassi Adj már csendességet... kezdetű éneke és a Kegyelmes Isten... kezdetű találhatók meg. A Kegyelmes Isten... úgy tudjuk, sehol másutt nem található meg a korban. Mivel ennek a szövegét korabelivel összevetni nincs mód, Korzenszky elemzésére támaszkodva adunk rövid ismertetést a szövegváltozatról. A Kegyelmes Isten... kapcsán azonban azt sem szabad elfelejtenünk, hogy ez Balassinak viszonylag kései, 1591-es, Lengyelországban szerzett verse. Az előzőekben már utaltunk arra, hogy nem zárhatjuk ki a szöveg kapcsán a lengyel zsoltárfordító, Kochanowski hatását, akitől az unitáriusok is fordítanak zsoltárokat.

Korzenszky elemzése végig azt mutatja be a későbbi bécsi és lőcsei Istenes énekek kiadásokban szereplő variánsokkal való összevetése során, hogy az unitárius hagyományban szereplő szövegváltozat mennyire a gyülekezetiségnek van alárendelve. ${ }^{592} \mathrm{~A}$ szövegváltozatok összevetése során arra jut, hogy a Kegyelmes Isten... kezdetű ének „olyan szövegmódosulásokat, romlásokat mutat, amelyek inkább arra vezetnek, hogy emlékezetböl, gyakorlati énekes hagyomány alapján írhatta le az énekek gyüjtöje." ${ }^{.593}$ A szövegromlással kapcsolatban annyit azért megjegyeznénk, hogy bár néhol valóban romlik a rím vagy a ritmus, másfelől a hétköznapibb formák használatát poétikai szempontból valóban romboló hatásúnak tekinthetjük, a gyülekezeti éneklés szempontjából az ismertebb, egyszerübb megoldások használatát sikeresen oldja meg.

A 4. strófa 2. sora az unitárius forrásban így hangzik: ,sok javaidat úgy hullasd reám, mint szegény szolgádra.” A kritikai nyomán Korzenszky kiemeli, hogy a „szegény szolgádra” kifejezés az Istenes énekekben szereplő „te régi szolgádat” kifejezésnél közkeletübbnek számít, így itt az ismertebb kifejezés egy kevésbé szokásos formulát vált fel, amit Korzenszky az emlékezetnek, a gyülekezeti hagyománynak tulajdonít. ${ }^{594}$ Az 5. versszak 2. sora szintén egyszerübb, közérthetőbb az unitárius forrásban, mint a bécsi-lőcsei variánsokban: a Kassaiénekgyüjtemény ,és mindenkoron könyörgésemmel” kifejezése egyszerübb, mint az Istenes énekek „mindenek elött s mindenek fölött” formája. ${ }^{595}$

\footnotetext{
${ }^{592}$ KORZENSZKY, i.m., 49-54.

${ }^{593}$ KORZENSZKY, i.m., 54.

${ }^{594}$ KorSZENSZKY, i.m., 51.

${ }^{595}$ KORZENSZKY, i.m., 52.
} 
A hallás utáni lejegyzésben, a szóbeli hagyományozódásban látja az okát Korzenszky annak is, hogy az Istenes énekek változatában a 6. strófában található „viseljed gondomat” az unitárius kéziratban „viseld jól gondomat” lesz. ${ }^{596}$

A kolofonstrófa változása olyan méretű az unitárius szövegben, hogy azt gyakorlatilag értelmetlenné teszi. Ennek az oka többféle lehet, talán az ének lejegyzője is több változatot ismer, és a változatok összecsúsznak a végén. De attól sem tekinthetünk el, hogy ezt az éneket lejegyzője csak kéziratokból ismerhette, hiszen a kolofonstrófa nem feltétlen képezi részét az éneklésnek. Ahogyan láttuk az előző fejezetekben, a kolofonstrófák a gyülekezeti énekeskönyvekből is kikopnak idővel, s a helyüket a zsoltárok hivatkozó strófái, doxológia veszi át, vagy éppen elmaradnak, s a helyükre nem kerül semmi. Itt leírva mégis van kolofon, csak éppen nem értelmes, ami valószínüsíti, hogy a gyülekezeti éneklésben ez a strófa nem hangzott el, nem volt közismert, így azt a lejegyző máshonnan ismerheti, talán kéziratokból. (Az Istenes énekekben: „Kilencvenegyet mikor jegyeztek másfélezer felett,” a Kassai István énekgyüjteményben: „Ezerötszázban mikor irnának másfélezer felett.” ${ }^{597}$ A strófák sorrendje is változik, ahogy arra Korzenszky rámutat, ő azonban nem említi meg azt, hogy ennek a gyülekezet „széténeklésen,” a közismertségen, s emiatt az emlékezetből való felidézésén kívül dogmatikai okai is vannak.

A kilencstrófás Balassi-szövegből az unitárius forrás hetet közöl csupán, egyet, az utolsó előttit pedig nem a Balassi szövegböl illeszti oda: az a versszak egyik fennmaradt forrásban sincs benne a Kassai-énekgyüjteményen kívül. A Balassi-forrásokban a 4. versszak így hangzik: ${ }^{598}$

Mi hasznod benne, hogy ha veszélyre jutok kétség miatt, Kit fiad által hozzád váltottál, mint fogadott fiat?

Az utóbbi sor egyértelműen olyan dogmatikai tanítás, amely azt hangoztatja, hogy a megváltás Krisztus eljövetelével teljesült be. Ezt az unitáriusok nem veszik fel szövegváltozatukba, viszont a strófa helyett bekerül egy másik strófa, amely a Krisztus megváltása helyett azért könyörög, hogy az Úristen a Krisztus által jókat adjon. Így a Krisztus nem mint megváltó, az Isten fia jelenik meg, hanem olyan személyként lép elénk a szövegben, aki által, akinek a révén az Atya jókat tud adni:

\footnotetext{
${ }^{596}$ KORZENSZKY, i.m., 52.

${ }^{597}$ KORZENSZKY, i.m., 52-53.

${ }^{598}$ Az egyszerüség kedvéért a kritikai kiadás alapján hozom. (ECKHARDT, i.m. 131-32. 90. sz.)
} 
Áldj meg testemben, áldj meg lelkemben, áldj meg életemben,

A Krisztus által minden dolgomban mindörökké, Amen.

Ezáltal a strófa egy a kolofon előtti záró strófává is vált, éppen ezért, a lezártság, az unitárius értelemben dogmatikai zárásnak nevezhető versszak használata miatt talán a kolofonstrófát nem is énekelték, $s$ innen eredeztethető a lejegyző bizonytalansága.

Igen erősen megváltozott szöveg ez, s látható, hogy megjelennek itt mind a közköltészet felé tendáló, a szöveget érthetőbbé, egyértelművé tevő elemek, mind pedig az olyan strófakikopások - és hozzátételek, - amelyek dogmatikailag énekelhetővé teszik a szöveget az unitáriusok számára.

Korzenzkyvel együtt elmondhatjuk, hogy ennek a Balassi-szövegnek az Istenes énekek nyomtatásban való megjelenése előttről fennmaradt szövegváltozata tehát olyan, amely a gyakorlati énekes hagyományból íródott le. Balassi énekeit a 17. század első harmadában gyakorlati hagyományból, gyülekezeti éneklésből ismerték.

Tatrosy György énekgyüjteményében, (S 37) melybe a szövegeket 1618-ban írta be a tulajdonos, a Bizonnyal ismerem rajtam nagy haragod... kezdetü Balassi-ének egy strófája található meg, a 4. versszak, mely a következő variánsban lett rögzítve az énekgyüjteményben:

\footnotetext{
Anyámnak méhében bünben fogantatám,

noha abból töled ${ }^{599}$ megmosogattattam, ${ }^{600}$

de gyarlón maradtam,

és ismét az bünre ${ }^{601}$ visszatántorodtam.
}

Messzemenő következtetéseket nem vonhatunk le egy strófából, de látható, hogy egyik nyomtatott forrással sem egyezik a variáns, s igazából olyan változásokat tartalmaz, melyek a gyülekezeti éneklésnek a sajátjai: a szórendcsere és az egyszerübb kifejezés, az utolsó sorban az első sor szavának ismétlése. Ez az emlékezetből a Conspiratio Kendiana szövege mellé oldalt a lapra leírt egy versszak azt mutatja, hogy Tatrosy György fejből írja oda a szöveget, tehát ismeri, felidézi, nem másolja valahonnan. Annak ellenére, hogy a korból

\footnotetext{
599 Bécs, Löcse, az 1700-as unitárius magánhasználatra szánt énekeskönyv: Melyböl noha töled; ECKHARDT föszövegében (i.m. 5. sz) Kiböl noha töled.

${ }^{600}$ Minden másban: kimosogattattam. Az adatokat itt is, a későbbiekben is a hálózati kritikai kiadásból veszem. Balassi Bálint összes verse, hálózati kritikai kiadás, szerk. HORVÁTH Iván, TóTH Tünde, Gépeskönyv, 2002, ver. 2.0. http://magyar-irodalom.elte.hu/gepesk/bbom/itart.htm (Utolsó megtekintés: 2015. 09. 17.)

${ }^{601}$ Minden más forrásban, kiadásban: annak utána
} 
nincs másik ismert szövegváltozatunk, Tatrosy György íródeák emlékezetből tud idézni 1618ban Balassi-szöveget.

A versnek más forrását nem ismerjük a korból, először a rendezetlen kiadásokban jelenik meg. Tatrosy György énekeskönyve azért is különleges, mert tudtunkkal ő az egyetlen íródeák a 17. században, akinek önéletírása maradt ránk. ${ }^{602}$ Ezt 1645-ben kezdi írni, s kiderül belőle, hogy árvasága és gyámság alá helyezése utána 1612-ben Kolozsvárra kerül, s a kolozsvári ítélőbírónak, Kassai Istvánnak lesz az inasa, s ennek a Kassai Istvánnak István nevü gyermekével egy iskolába is jár. 1618-ban, az énekgyüjtemény keletkezésekor Brassóba megy, de később visszatér még Kassaihoz Kolozsvárra több ízben is, s íródeákja lesz. Ez a Tatrosy György tehát olyan személy, aki a Balassi-szöveget is tartalmazó gyüjteményét 1618ban írja, s köze van a 17. század eleji kolozsvári kancelláriához, hiszen a Kassai István énekgyüjteményének 1629-es tulajdonosát, Kassai Istvánt szolgálja. Nem zárhatjuk ki, hogy a 17. század első évtizedeiben Kolozsvárt, a kancellária környékén esetleg volt valami olyan forrás, amelyből kiindulva ezek a szórványosan, egy-egy kéziratos vagy nyomtatott énekgyüjteményben megjelenő, szövegváltozataikban erősen a gyülekezeti énekeltséget mutató Balassi-szövegek leíródtak. Így Vadai István azon állítását, hogy esetleg Petki János kancellár kezében lehetett Balassi-gyűjtemény, a 17. század első harmadából fennmaradt, kolozsvári eredetű énekgyüjtemények Balassi-variánsai alátámasztani látszanak, de legalábbis nem zárják ki azt. Ám mivel ezek a fennmaradt szövegváltozatok markáns eltéréseket tartalmaznak a későbbi Istenes énekek szövegváltozataihoz képest, a gyülekezeti éneklésre szabott változatok semmiképp nem lehetnek a későbbi Istenes énekek forrásai. A következőkben néhány korai Balassi-variáns elemzésével igyekszünk erre rámutatni.

\section{4. A korai Balassi-variánsok összevetése}

\section{4. 1. Bünös és/vagy bús? Az Ó, én kegyelmes Istenem... változatai}

Az Ó, én kegyelmes Istenem... kezdetü ének (RPHA 1109) az unitárius anyagban nótajelzésként szerepel két lengyel zsoltár fordításánál. ${ }^{603}$ Ahogy arra igyekeztünk rámutatni,

\footnotetext{
${ }^{602}$ Önéletírását közli és elemzi: Doм0коs Pál Péter, Tatrosy György önéletírása és történeti feljegyzései, ItK, 1957, 238-261. Az adatokat ez alapján közlöm.

${ }^{603}$ Ím, s hogy kiált; Reménységem vagy Istenem...
} 
feltehetően ismerték azokat a szövegeket, amelyeket gyülekezeti ének nótajelzésére használnak, hiszen a gyülekezet számára nem mondana sokat, ha soha nem hallott énekekre hivatkoznának a kiadások.

Azt, hogy a protestáns éneklésben ismert versről van szó, alátámasztani látszik az is, hogy az unitárius nótautaláson kívül a vers szövege megvan több forrásban is: a Detsikódexben (S 25), a Lipcsei-kódexben (S 32) és a Lugossy-kódexben (S 47) is. Ismertségéről, elterjedtségéről és népszerüségéről - annak ellenére, hogy nyomtatásban nem jelent még meg - az is tanúskodik, hogy a Lugossy-kódexben ${ }^{604}$ négy strófával több van, mint bármely nyomtatott kiadásban. Ez a négy strófa nincs meg a Detsi-kódexben. A Lipcsei-kódexben viszont olyan többletstrófa van, amely a többi forrásban nincs meg. Úgy tűnik tehát, hogy ez a Balassi-szöveg annak ellenére, hogy az Istenes énekek kiadásáról még nem beszélhetünk ebben az időben, mégis olyan népszerü volt, hogy hol hosszabb, hol rövidebb formában énekelték, még új strófák is belekerültek. Az énekeltségre, az orális hagyományra utalnak a változatok bizonyos jellemző jegyei is: a szórendcserék, a köznapibb, közismertebb kifejezések használata a későbbi Istenes énekek variánsaihoz képest, illetve a strófák felcserélései. ${ }^{605}$ A korai variánsok olyan erős változásokat tartalmaznak, amelyek alapján azt mondhatjuk: az ének nagy népszerüségnek örvendhetett, másolhatták, énekelhették, „széténekelhették” azt már a 17. század első évtizedeiben.

A második strófa 4. sora a Detsi-kódexben így szerepel: „ez okáért megfizetem.” A Lipcsei-kódexben „de hiszem már megfizetem” áll, a Lugossy-kódexben pedig „,de hiszem már megfizettem." Az Istenes énekek kiadásaiban más forma szerepel, mely már azonos a rendezett és a rendezetlen kiadásokban, de azért szórendcsere megfigyelhető a kiadások között. „Kiért ím lám megfizettem” szerepel az 1633-as bécsi, az 1665-ös kassai, és az 1660 körüli bártfai kiadásban, „Kiért lám ím megfizettem” pedig a következőkben: Kolozsvár, 1669-77; 1677; 1681; Mátray-kódex, Lőcse 1670, 1671, Pozsony $1676 .{ }^{606}$

Korzenszky nyomán mondhatjuk, hogy tipikusan a szóbeli, énekelt hagyomány sajátja az is, amikor a szokatlan, nem általános szórendet a strófákban hétköznapi szórenddel helyettesítik. A harmadik versszak második sora szemléletesen mutatja ezt a jelenséget: minden Istenes énekek kiadás a nem hétköznapi, nem megszokott, művészibb formát használja, másfelől pedig minden korai kéziratos forrás egymástól ugyan különböző módon,

\footnotetext{
${ }^{604}$ A Lugossy-kódex szövegváltozatát Klaniczay közléséből idézem. (im., 333-335.)

${ }^{605}$ Terjedelmi okokból csak néhány példát hozunk a megfigyelt jellegzetességekre, hiszen több Balassi-vers is elemzésre kerül majd.

${ }^{606} \mathrm{Az}$ adatokat a hálózati kritikai kiadásból vettük: http://magyar-irodalom.elte.hu/gepesk/bbom/itart.htm. Letöltés: 2015. március 18-án. A továbbiakban is innen vesszük az elemzés Istenes énekekre vonatkozó adatait, ha nem jelezzük külön, hogy más a forrása.
} 
de köznapibb szórendet használva hozza a sort. Minden variáns olyan tehát, amelyet a gyülekezeti hagyomány már egyszerüsített, mire lejegyzésre került.

A nyomtatott Istenes énekek hagyományban a 3. versszak első két sora a következő: ${ }^{607}$

Legyen azért elég immár,/ Sok búm és szenvedtem nagy kár...

\section{A Detsi-kódex változata:}

Legyen elég azért immár,/vallottam sok bút és sok kárt.

A szótagszám mindenütt kijön, úgy változik a szöveg, de látható a Lipcsei-kódex változatából is, hogy a kéziratos hagyomány mennyivel köznapibb:

Legyen elég azért immár,/ vallottam sok bünt és sok kárt. ${ }^{608}$

A Lugossy-kódex változata a második sor és-ét kiveszi, felsorolást csinálva, de a szótagszám megmarad, mert a sor elején egy „én”-nel nyit:

Legyen elég azért immár, én vallottam sok bút, sok kárt. ${ }^{609}$

Talán ez a néhány példa is rámutat arra, hogy Korzenszky Richárdnak a Kassai István énekgyüjteményében található Balassi-szövegekről tett megállítása nemcsak az unitárius anyagra, hanem az összes, az Istenes énekek kiadása előttről fennmaradt forrásra is alkalmazhatónak látszik. Így azt mondhatjuk, hogy az unitárius gyülekezeti énekeltségen kívül minden bizonnyal énekeltek Balassi-szövegeket más felekezetek is, hiszen a szövegváltozások az orális hagyományban terjedő szövegek sajátosságait mutatják.

\section{4. 2. A király, a bölcs és a mágus: a Pusztában zsidókat... változatáról}

Ez a szöveg azért is figyelmet érdemel, mert ahogyan azt az előzőekben kifejtettük, Klaniczay kimutatta, hogy csak a rendezett kiadásokban jelenik meg, tehát egészen későn lesz

\footnotetext{
${ }^{607}$ A hálózati kritikai kiadás alapján, ld. előző lábjegyzet.

${ }^{608}$ A Lipcsei-kódexet kézbe venni nem tudtam, ezt ECKHARDTÓL idézem. (im. 269.)

${ }^{609}$ KLANICZAY, i.m. 334.
} 
csak az Istenes énekek része. A nyomtatott megjelenés elött csak néhány forrásból maradt ránk: az egyik a Kuun-kódex, a másik pedig a nyomtatott unitárius énekhagyomány. ${ }^{610}$

Textológiai mintapélda lehetne a 2. strófa szövegének változása. Ha a Bibliában több történetben is szerepel utat mutató csillag és három személy, akkor miért ne lenne a különböző szövegváltozatokban különböző szereplőkkel elmesélve a történet? A második versszak első sora a következő:

Te adtál csillagot három szent királynak,...

Ezt a változatot tartalmazza a Balassa-kódex, a Kuun-kódex és az 1602-15 közötti és az 1632-es, illetve az 1697-es unitárius gyülekezeti énekeskönyv is, az Istenes énekek kiadásai közül pedig az 1670-es és az 1671-es Lőcsei, az 1669-77 közti, az 1677-es és az 1681-es kolozsvári kiadások.

Néhány kiadásban a királyok mágusokká változnak: az 1676-os pozsonyi és az 1699es pozsonyi kiadásokban a „három szent királynak” helyére „ama’ mágusoknak” kerül.

Ugyanazon a gyülekezeti hagyományon belül az unitáriusok kétféle variánssal jelentetik meg a szöveget. Az 1700-as magánhasználatra szánt énekeskönyvben - s az unitárius szöveghagyomány alapján feltételezhetjük, hogy az ezt megelőző magánhasználatos énekeskönyvekben is - a három szent király három szent bölccsé változik. Úgy gondoljuk, ez is azt mutatja, hogy a nyomtatott hagyományban rögzített változatokról sem mondható el feltétlenül, hogy pontosan ezek, pontosan ebben a formában hangozhattak el a templomban. Merész elképzelés lenne, hogy otthon bölcsekröl, a templomban királyokról kötelező énekelniük a híveknek. Sokkal valószínűbb, hogy a hagyományban mind a kettő élt, csak a nyomtatványok az előző kiadásokat követve nem egységesítették a felekezeten belül sem a szövegeket: egy-egy ének (még akkor is, ha az Balassi-szöveg) variánsaiban élt egy gyülekezeten belül is. ${ }^{611}$

A közösségi igényeknek való megfelelést mutatja, hogy az unitárius kiadásokban nem szerepel már sem a kolofonstrófa, sem az azt megelőző, szerelmi tematikát feldolgozó versszak. A kolofonstrófák kikopásáról már volt szó, ám érdemes megjegyezni, hogy az Istenes énekek kiadásai minden esetben közlik a kolofonstrófát is, míg az unitárius

\footnotetext{
${ }^{610}$ Láttuk, hogy megvan az RMNy 983-ban, azaz az 1602-15 közötti kiadásban, majd tartalmazza az 1632-es gyülekezeti énekeskönyv is. Emellett tartalmazta az elveszett 1623-as magánhasználatra szánt gyüjtemény, s ebböl arra következtethetünk, hogy az 1635-ös, makulatúrán fennmaradt töredékben is benne volt. (RMNy 1615.) Ezeknek nyomán kiadásra kerül a század végi unitárius énekeskönyvekben is: az 1697-es gyülekezeti, és az 1700-as magánhasználati is tartalmazza.

${ }^{611}$ Túri Tamás hívta fel a figyelmemet arra, hogy ismerünk 18. század eleji unitárius prédikációt, (MsU 288.) amely amellett érvel, hogy a bibliai bölcsek mágusok, és nem királyok. A 18. század eleji unitárius elképzelések tehát úgy tűnik, igyekeztek határozott álláspontot képviselni, emiatt e téma érdemes lehet a további kutatásokra. Köszönettel tartozom Túri Tamásnak az észrevételért.
} 
énekeskönyv nem. A szerelmi témájú strófát pedig egyedül a Kuun-kódex és a Balassa-kódex őrizte meg. Eckhardt Sándor a vershez füzött jegyzetében meg is jegyzi, hogy ,érdekes esete ez a közösségi igény és az egyéni költés harcának."612 Ha összegezni akarjuk, a Pusztában zsidókat... szövege olyan forrásnak tünik, amely jóval kevesebb helyen bukkan fel a nyomtatott megjelenése előtt, viszont annak ellenére, hogy ismertségének semmi nyoma az 1589-es szereztetés és az 1602-15 közötti nyomtatott megjelenése között, már olyan változatban jelenik meg az első nyomtatott kiadásban, amely abszolút a gyülekezeti éneklésre van szabva, azoknak az igényeknek van a szöveg alárendelve. Valahonnan, valahogyan ezt a Balassi-szöveget is ismerni, használni kellett ahhoz az énekelt hagyományban is, hogy így átalakuljon.

VIII. 4. 3. Már, ma, most. A Bocsásd meg, Úristen... változatai

Ez a Balassi-vers az, amely a legkorábban jelenik meg gyülekezeti énekeskönyvben nyomtatásban. Szenci Molnár Albert zsoltáros könyvének oppenheimi kiadása 1612-ben beveszi a gyülekezeti énekek közé, de már az 1607-es herborni kiadásának előszavában is szól róla: a legszebb éneknek mondja három gyülekezeti ének szemléltetésekor. Itt csak egy strófája van meg, de feltünő, hogy Szenci Molnár minden bizonnyal fejböl idézi a szöveget, már az incipitet is variánsában hozza, a Bocsásd meg, Úristen helyett ugyanis személyesebb formula áll itt: Bocsásd meg, Istenem.

Az incipit is változást hoz, ami azért érdekes, mert a versek eleje nehezebben változik, mint a közepe, az incipit tulajdonképpen az ének ismertető jegye. Az előzőekben, a szövegváltozási tendenciák ismertetésénél láthattuk viszont, hogy a gyülekezeti énekhagyományban nem ritka, hogy az énekek kezdősora is variánsokban létezzen.

Az unitárius énekeskönyvek mindegyike hozza az éneket, a magánhasználatra szántak is, s Eckhardt megállapítja, hogy a Lipcsei-kódex szövege igen hasonló az unitárius szövegváltozathoz. ${ }^{613}$ A többi gyülekezeti ének azonban, mely megtalálható a két forrásban, nagy különbségeket mutat, erősen eltérnek egymástól. A Balassi-szövegek közül a Bölönikódex ezt az egyet tartalmazza, amely szintén az unitárius nyomtatványokhoz áll a legközelebb, ám számos ponton el is tér attól. A dogmatikai változásokat tárgyaló részben a

${ }^{612}$ ECKHARDT, i.m., 256.

${ }^{613}$ ECKHARDT, i.m., 202. 
Bölöni-kódexről bővebben is szó volt, s ez a variáns ismét azt mutatja, hogy a háromszéki lejegyző nem a nyomtatványból másol szolgaian, hanem feltehetően az ott, akkor a gyülekezetben használt változatot rögzíti. A Bölöni-kódex a két $S$-sel kezdődő strófát kihagyja (az akrosztichont ezzel értelmetlenné téve: BalaiBalinthe), de több olyan pont is van, ahol az unitárius kiadástól eltér, ám az oppenheimi kiadással azonos. A nyomtatott énekhagyomány református és unitárius változata egyaránt nyomot hagy a kézirat variánsán. $^{614}$

Az unitárius kiadások is megörzik ennél a versnél az önreflexív záró strófát, mely bár nem klasszikus kolofon, de az unitárius kiadásban hozott szövegváltozat a szerzőséget állítja előtérbe, míg a többi forrás már az énekeltséget tanúsítja, még az Istenes énekek kiadásai is. $\mathrm{Az}$ unitárius kiadásokban a szerzésre való reflexió miatt a rím is elromlik: szivemböl/lelkével/ördöggel. A többi forrás viszont éneklést, énekeltséget, hangzó használatot említ, nem szerzést, mint az unitárius.

Unitárius: (nyomtatványok és a Bölöni-kódex is): Ez éneket szerzém keseredett szivemböl.

A Kuun-kódex: Éneklém ezeket ily keseredett szívvel.

Az oppenheimi és a bécsi kiadásban: Éneklém ezeket megkeseredett szívvel.

A 11. versszak némely változatban E./1.-es személyü marad ${ }^{615}$ - ne felejtsük el, hogy a vers végig E./1.-ben, illetve, amikor a beszélő a lelkéről szól az Istennek, akkor E./3.-ban beszél - míg több kiadás T./1.-re vált ebben a versszakban. A többes szám némileg ellentmond a szövegkörnyezetnek, így nem kizárt, hogy a számtalan E./1.-es változat valamelyike áll közelebb a szerzői kézirathoz, nem a többes számú változatok. Nem kizárt, hogy a többes számot hozó variánsok inkább a fentebb elemzett gyülekezetiesedett, a közösségi éneklési szokásoknak alávetettek.

Ennek a strófának a teljes ismertetése szinte lehetetlen terjedelmi okok miatt, hiszen némi túlzással élve ahány hordozó, annyi változata van. A számos változat oka nem is csak a többes szám - egyes szám problémára vezethető vissza, hanem feltehetően dogmatikai okokra

${ }^{614}$ Például a 4. versszakban az unitárius nyomtatványokban „hogy vétkezett” áll, a Bölöni-kódexben és az oppenheimi kiadásban viszont „sok bünt tött” szerepel. A Bocsásd meg, Úristen... szövegösszevetésében a szórendcserék, egyszerüsítő tendenciák éppúgy megfigyelhetők, mint számos gyülekezeti ének esetében. Ez a dolgozat CD-mellékletében tanulmányozható.

${ }^{615}$ E./1.-es az 1602-15-ös unitárius kiadás változata: Inkább tekintsd Uram irgalmasságos voltod,/ és sok büneimnek ingyen megbocsánatját,/ mit engedhetnél meg, ha nem vétkeznének te ellened a hívek. A hálózati kritikai kiadás föszövegét hozva a legtöbb helyen pedig így szerepel: Irgalmasságod is annál inkább kitetszik,/amennél több vétkünk nekünk megengedtetik,/ inkább kegyelmedben, mint büntetésedben te irgalmad tündöklik. 
is: az irgalom és a bünbocsánat kérdésében nem mindegy, hogy mely felekezet mit mond. Így ennek a strófának a nagy variabilitását elsősorban az okozhatja, hogy minden felekezet igyekezett a maga dogmatikai álláspontjának megfelelőre kovácsolni a strófa mondanivalóját. A többes szám használata pedig annak ellenére, hogy a vers beszédhelyzetébe nem illeszkedik, erősíti a gyülekezeti hangot, miszerint az isteni irgalom mindenkié.

A többes szám első személy egyedül közvetlenül a záró strófa elött jelenik meg, amikor is az Úr áldása kerül középpontba, és a büntől való tartózkodás lesz a fö mondandó. Mintha a személyes bünvallást, bünbánatot ezzel a strófával tenné általánossá az ének. Ahogyan arra Pap Balázs rámutat, nem elképelhetetlen, hogy ez és az ezt követő záró strófa utólagos kollektivizálás eredménye, s a BalassjBalint akrosztichon után a vers szerzői változata véget ért, és az utolsó két versszak utólagos betoldás eredménye. ${ }^{616}$

Ebben a strófában az isteni kegyelmet azonban az egyes változatok különbözőképpen értik. Van olyan variáns, amelyben az áll: ki most megkegyelmeze. ${ }^{617} \mathrm{Ez}$ feltehetően egy katolikus variáns: a bünbocsánat, bünvallás végén az Úristen feloldozást ad: amint elhangzik a bocsánatkérés, a bünbocsánat aktusa is megvalósul. Ezt fejezi ki a versben szereplő „most.” Az unitárius kiadások közül a gyülekezeti énekeskönyvek mindegyike egy dogmatikai értelemben semlegesebb változatot hoz: ki ma megkegyelmeze. Ez a ma nem olyan erőteljesen a gyónásra utaló, mint a most, de feltehetően zavarhatta ez a sor a dogmatikára érzékeny füleket, mert az 1700-as kiadásban ritmusrontással a bűnök bocsánatának idejéről szóló részt kiveszi: ki maga megkegyelmeze szerepel.

Bár az 1633-as bécsi kiadásban is ez szerepel, de a későbbi Istenes énekek kiadások mindegyikében a következő áll: ki már megkegyelmeze.

A Bölöni-kódex variánsa pedig az isteni kegyelmet egyértelmüen már a múltban megtörténtként mutatja be: ki már megkegyelmezett szerepel a forrásban. Ebből is látszik, hogy a variánsok számos esetben tartalmaznak nemcsak az orális hagyományozódásra, de a felekezeti használatra utaló jeleket is.

\footnotetext{
${ }^{616}$ PAP, i.m., 338.

${ }^{617}$ Ez található a Kuun-kódexben, a Czerey-énekeskönyvben és az 1629-es bécsi Jézus szivét szerető... (RMNy 1422) katolikus nyomtatványban is.
} 


\section{4. 4. Szárnyát vagy szarvát? Az Adj már csendességet... korai variánsai}

Pap Balázs tanulmánya ${ }^{618}$ rámutat arra, hogy az Adj már csendességet... minden rendezetlen kiadásban Rimay-versek környezetében fordul elő, nem a Balassi-versek csoportjában. Szóhasználat és dogmatikai szempontok figyelembevételével Pap Balázs említett tanulmánya arra jut, hogy a közvetlen érvek hiányának ellenére nem kizárt, hogy az Adj már csendességet... nem Balassi-vers, hanem Rimay János szerezte azt. Többször céloztunk a dolgozatban arra, nem tudjuk, az 1602-15 között kiadott unitárius énekeskönyvnek volt-e korábbi kiadása, s azt sem tudjuk rekonstruálni pontosan, hogy az Enyedi György által a prédikációjában említett unitárius énekeskönyvecske mit tartalmazhatott. Szembetűnő viszont, hogy az 1602-15 között nyomtatott unitárius énekeskönyvben a Pusztában zsidókat... és a Bocsásd meg, Úristen... az ábécérendbe beillesztve, a gyülekezeti énekekbe beágyazva található, az Adj már csendességet... viszont pótlásként, az ábécérend után, feltehetően egy újabb ábécérendbe szervezett, frissen a kötetben helyet kapó énekrész első darabját képezte. ${ }^{619}$ Úgy tünik tehát, hogy az Adj már csendességet... szövege nem a többi Balassival egyszerre kerül be az unitárius gyülekezeti éneklésbe.

A vers kötetbeli helye arra is utalhat, hogy az Adj már csendességet... nem ugyanabból a forráscsoportból kerül a gyülekezeti éneklésbe, mint a Balassi-szövegek, hanem valahonnan máshonnan lesz ismert, a gyülekezet által az orális hagyományba kerülő.

$\mathrm{Az}$ ének az Istenes énekek előtt nyomtatásban csak az unitárius gyülekezeti- és magánhasználati énekeskönyvekben jelenik meg, s az 1602-15-ös kiadástól kezdve mindegyikben szerepel. Kéziratos változatai pedig a mára megsemmisült Vasady-kódexben (S 27) és Kassai István énekgyüjteményében (H 32) találhatók.

A Vasady-kódexet ma már csak Dézsi Lajos hagyatékából ${ }^{620}$ és tanulmányából ${ }^{621}$ ismerjük, ez alapján viszont, mivel az elemzett versről nem készít másolatot, sajnos nem

\footnotetext{
${ }^{618}$ PAP Balázs, Az Istenes énekek margóira = GHESAURUS, Tanulmányok Szentmártoni Szabó Géza hatvanadik születésnapjára, szerk. CsöRSZ Rumen István, rec.iti, Bp., 2010, 335-342. Letöltve: 2015. 03. 19-én. http://plone.iti.mta.hu/rec.iti/Members/szerk/ghesaurus-1/PapBalazs-Ghesaurus.pdf

${ }^{619}$ A kötet csonkasága miatt a pótlásban csak az Adj már csendességet... első versszaka van meg. Az unitárius énekeskönyvekben viszont a 17. századi kiadások során általánosnak mondható, hogy a „frissen” bevett szövegeket toldalékként közlik, új ábécérendben. Ilyen az 1632-es énekeskönyvben is van, ahová számos Thordai-zsoltár kerül be, de az 1700-as magánhasználatra szánt énekeskönyv szerkezete is olyan, hogy az előző kiadások énekeit közli ábécérendben, majd új ábécérendbe szervez még ugyanannyi éneket, melyek feltehetően itt jelennek meg az unitárius magánhasználatra szánt gyüjtemény darabjaiként elöször.

${ }^{620}$ A Dézsi hagyaték Vasady-kódexet érintő részei megtalálhatók a Szegedi Tudományegyetem Egyetemi Könyvtárában. (Jelzetei: Ms 00620; Ms 00834)
} 
tudunk elemzést adni. Érdekes viszont, hogy a Vasady-kódexbe másolt unitárius káté622 alapján Debreczeni Sándor nyomán a kódexnek unitárius eredetet tulajdoníthatunk, ahogyan arra a forrás ismertetésénél már utaltunk. ${ }^{623}$ A Dézsi által közölt részletekből kitünik, hogy az Adj már csendességet... szövege az unitárius nyomtatványokban található variánssal rokonítható, s erre Debreczeni tanulmánya is felhívja a figyelmet. ${ }^{624}$ Így hangsúlyoznunk érdemes, azt is, hogy a Vasady-kódex nem csak 1613-15 közötti, ahogyan azt mondani szokás, hanem később is kerülnek bele szövegek.

A kódex egyik bejegyzése szerint ugyanis - amikor hosszas Ovidius-idézetek és fordítások találhatók a lapokon - úgy tünik, hogy 1624 után egyértelmüen unitárius kezekben van, ők írnak bele. Egy a Heroidákból latinul idéző résznél ${ }^{625}$ vannak magyar nyelvü, verses fordítások is, ami alá a következő van írva: A Clarissimo Viro Ioann M. Varsolczio Explica: Claud. AD. 1624 idibus Decem. Az unitárius Varsolczi M. János tanulmányairól, müveltségéről és munkásságáról bővebben nem szólunk, ${ }^{626}$ de a Varsolczi Heroidamagyarázatot és fordítást Kolozsvárra tevő másoló alapján egyértelmü, hogy a kódex jelentős része nem az 1613-15-ös évben keletkezett, hanem később, kolozsvári unitárius környezetben. Erre utal az antik szerzők után bemásolt, már említett ismeretlen unitárius káté is. ${ }^{627}$ Tehát ha a rendkívül összekeveredett gyülekezeti énekrészt nézzük, az Adj már csendességet... egykor itt megtalálható szövegváltozata, - lévén, hogy a sok helyütt megjelenő záró doxológia nincs meg a végén, ${ }^{628}$ az első strófái pedig a nyomtatott unitárius variánssal szinte teljesen azonosak - mindenképpen unitárius lejegyző keze nyomának tudható be. Ezáltal kizártnak tekinthetjük, hogy az Adj már csendességet... első forrása a Vasady-kódex legyen, a Vasady-kódex változata minden bizonnyal a nyomtatott unitárius változatból, vagy az unitárius énekhagyományból kerülhetett át, hiszen az énekek előtt a kódexben a dátum 1624, a helyszín Kolozsvár, és unitárius személyek vannak említve.

A vers első strófája, és a második strófa első sora a Vasady-kódexről fennmaradt adatok fényében az unitárius nyomtatvánnyal egyetlen ponton nem azonos, amely azonban

\footnotetext{
${ }^{621}$ DÉzSI Lajos, A Vasady-kódex, ItK, 1913, 14-27.

${ }^{622}$ A Dézsi hagyatékban található átiratot megnézve ez egy olyan unitárius szellemủ káté, melyet a mai napig nem ismerünk, létezéséről semmit nem tudunk. (Molnár Dávid segítségével igyekeztem utánajárni, hogy mi lehet a káté, de nem találtuk nyomát az unitárius kátéirodalomban annak ellenére, hogy dogmatikája egészen nyilvánvalóan unitárius.)

${ }^{623}$ DeBReCZENi Sándor, A Vasady-kódex eredete, Keresztény Magvető, 1940, 247-250.

${ }^{624}$ DEBRECZENI, i.m.

${ }^{625}$ DÉZSI, 1913, i.m. alapján a 38a lapon.

${ }^{626}$ Balázs Mihály részletező életrajzot ad: BALÁzs Mihály, Altdorf és az erdélyi unitáriusok, Keresztény Magvető, 2012, 211-228.

${ }^{627}$ Ezt a jelleget emeli ki DEBRECZENI Sándor, i.m.

${ }^{628}$ DEBRECZENI, i.m., 250.
} 
csak a Vasady-kódex szövegváltozatában található meg, a többi nyomtatott forrásban sincs ilyen variáns. A nyomtatott unitárius hagyományban a következőképp néz ki a szöveg:

1.Adj már csendességet, lelki békességet, mennybéli Úr.

Bujdosó elmémet, ódd bútól éltemet, kit sok ${ }^{629}$ kín fúr.

2. Sok ideje hogy már, lelkem szomjuhon vár mentségére....

Az „ódd bútól éltemet” forma van meg az 1633-as bécsi kiadásban és az 1660 körüli kassaiban, de az összes többi kiadás szívemet hoz. ${ }^{630}$ A Balassi-kritikai kiadás szerint minden forrás azonos a 2. strófa elején: „sok ideje immár, hogy lelkem szomjan vár mentségére.”

Kivételt képez ez alól az unitárius nyomtatott hagyomány, a Kassai István énekgyüjtemény variánsa - amely, ahogyan azt az előbbi alfejezetekben kifejtettük, unitárius gyüjtemény - és a Vasady-kódex.

Úgy tünik tehát, hogy az Istenes énekek kiadásain kívül ez a szöveg egyedül a 17. század eleji kolozsvári unitárius forrásokban maradt fönn, ellentétben a Balassi-hagyomány többi vizsgált darabjával, amelyek viszont szórványosan másutt is megjelentek. Így valóban nem zárhatjuk ki, hogy máshonnan lett az unitárius éneklés része, mint a fentebb tárgyalt néhány Balassi-vers. Ez az apró adalék legalábbis összhangban van Pap Balázs érvelésével: a korai, szórványos, gyülekezeti énekeltségű Balassi-hagyomány és az Adj már csendességet... korai szöveghagyománya nem azonos, egyetlen közös pont az 1602-15 között kiadott unitárius gyülekezeti énekeskönyv, ahol viszont toldalékként jelenik meg a szöveg, nem az ábécérendbe illesztve, mint a Balassi-versek.

\section{Kitérés}

Messzire vezető probléma, egy önálló dolgozat lehetne a Rimay- és Balassi versek 17. század eleji előfordulásának vizsgálata. Az Adj már csendességet... kapcsán, Pap Balázs gondolatmenete nyomán talán nem mellékes viszont megjegyezni, hogy az első gyülekezeti énekeskönyvben toldalékként szerepel, nem úgy, mint a két Balassi-szöveg, tehát feltehetően ekkoriban kezdett népszerü lenni, friss gyülekezeti éneknek tekinthető. Rimay-verseket nem is vesznek be az unitárius gyülekezeti énekhagyományba, az 1623-as magánhasználati

${ }^{629}$ A Vasady-kódexben Dézsi alapján: csak. Ez az egyetlen eltérés van csupán.

${ }^{630}$ Ld. a hálózati kritikai kiadást. 
énekeskönyvben viszont találkozunk kettővel, a Legyen jó idő csak... és az Ó, ki későn futok... kezdetüvel. Ha a dolgozat elején hozott érveimet elfogadhatónak találjuk, miszerint az első unitárius énekeskönyv 1616 körül keletkezett, akkor elmondható, hogy ez a toldalékban megjelenő Adj már csendességet... és az 1623-ban a magánhasználatban megjelenő Rimay versek talán egy hagyományágon válnak ismertté az unitárius éneklésben, amely ismertté válás későbbi, mint a Balassi-szövegek népszerüvé válásának időpontja. A Rimay-szövegek ismerete az unitárius hagyományban 1627-re már egészen bizonyos, hiszen Thordai János zsoltáraiban kimutatható a hatása. ${ }^{631}$ Pap Balázs felvetését az unitárius korpuszból azzal is alátámaszthatjuk, hogy Thordai János zsoltáraiban a számos Rimay-hatással szemben alig találkozunk Balassi hatással, összesen kétszer használ Thordai Balassi-nótajelzést. Egyszer az Ó, én kegyelmes Istenemet, melyről nem kizárt, hogy esetleg még a többi Balassi-versnél korábban bekerül az unitárius hagyományban ismert szövegek közé, hiszen a feltehetően a 16. század végén lengyelből fordított unitárius énekeknek már nótajelzése ez a Balassi-vers. A Thordai 68. zsoltárához nótajelzésként írt Balassi incipit pedig nagy változást mutat az $O$, én kegyelmes Istenem... bármelyik későbbi nyomtatott vagy kéziratos forrásához képest. A Thordai-zsoltárok nótajelzésében a Balassi-variáns első két sora a következő:

Ó, én kegyelmes Istenem,/ mely igen kesereg lelkem.

A hálózati kritikai kiadás alapján minden egyes későbbi forrás a következő kezdősorokat hozza:

Ó, én kegyelmes Istenem,/ mely igen megverél engem.

Látható, hogy igen erős eltérés tapasztalható az unitárius hagyományban meglévő két sor, és a többi forrás idézett része között, így arra gondolhatunk, hogy az unitáriusok ezt az éneket is igen korán, igen erőteljes változtatásokkal ismerték, noha nyomtatott vagy kéziratos forrásból a teljes szöveg nem maradt ránk a korból.

A Thordai-zsoltárok számtalan Rimay-hatása mellett tehát ez a nótajelzés a Balassiszövegek ismeretére utal. Megemlítjük még, hogy nótajelzés gyanánt előfordul még összesen két alkalommal az Adj már csendességet... Ezek a zsoltárok metrumukban is azonosak a

${ }^{631}$ Zentai Mária, Rimay-hatás Thordai János zsoltáraiban = Acta Universitatis Szegediensis, Acta Historiae Litterarum Hungaricarum, XIII, Szeged, 1993, 99-109. 
nótajelzésként hivatkozott Balassi(?)-verssel. Ezek a Jó az egyességben...(133. zsoltár), és az Úristen a király... (21. zsoltár).

Thordaira a zsoltárok 1627-es írásakor sok Rimay-vers hatással van, de Balassi Bálintnak csak kettő szövege fordul elő nótajelzésként, s ezek közül az Adj már csendességet pont kétes szerzőségű. A számtalan Rimay-hatás miatt, és az Adj már csendességetnek az első nyomtatott unitárius énekeskönyvben toldalékként való szereplése miatt talán nem túl merész dolog azt mondani, hogy Pap Balázs felvetését, miszerint inkább Rimay- szövegről van szó az Adj már csendességet... esetében, a korai unitárius források ha alá nem is támasztják, de ellent semmiképp nem mondanak annak. ${ }^{632}$

Visszatérve az Adj már csendességet... unitárius variánsának elemzéséhez az, hogy ez a korai variáns a kollektivizálásra jellemző sajátosságokkal rendelkezik, tetten érhető többek között a 4. strófában is: az unitárius forrásokban a „sok bünöm éktelen, romlott, való” felsorolás olvasható, míg minden nyomtatott hagyományban „romlást valló” bünről van szó. Egyszerü felsorolássá alakítja az unitárius variáns a jelzős szerkezetet.

Szintén felsorolássá változik az 5. versszak első sora is, amely által gyakorlatilag az értelme is elvész a sornak, de az unitárius nyomtatott hagyomány a 17. században végig ehhez az alakhoz ragaszkodik: „Jó voltod változást, gazdagságot, fogyást ereszthető.” Az Istenes énekek kiadásaiban megjelenő, értelmesnek is tünő birtokos szerkezetből (gazdagságod fogyást) felsorolás lesz, mely lényegesen egyszerübb.

Az eredeti, esetleg szerzői változathoz közelebb állónak tünik viszont a 7. versszak az unitárius gyülekezeti énekként szolgáló változatban, mint az Istenes énekek szöveghagyományának nagy többségében. ${ }^{633}$

Nyisd fel hát karodnak, szentséges markodnak áldott zárját, add meg életemnek, épséges fejemnek letört szarvát.

Szentmártoni Szabó Géza rámutat arra, hogy a jobbnak ezt, a szarv-metonímiát alkalmazó változatot kell tekinteni, nem a szárny-hasonlatot hozót. ${ }^{634} \mathrm{~S}$ ahogy látjuk, a legkorábbi nyomtatott és kéziratos hagyományokban ez lelhető fel. Ebből a szempontból nem érdemes elvetni ezeket a szövegeket, mint „rosszabb,” széténekelt, a gyülekezeti éneklés

${ }^{632}$ A rímeket, rímbokrokat tárgyaló fejezetben igyekeztünk néhány olyan példát bemutatni, amelyben Thordai Rimay rímeit használja elöszeretettel. Az Adj már csendességet... első strófájának rímpárja egy alkalommal elöfordul a Thordai zsoltárokban is: a 68. zsoltár 20. versszaka az Úr-fúr-Úr-gyúr rímet hozza. (Ld. RMKT 17/4. 123. sz., 265.)

${ }^{633}$ Csak az 1660 körüli bártfai és a kolozsvári kiadások hozzák azt, amelyet az unitárius források mindegyike.

${ }^{634}$ SZENTMÁRTONi SzABÓ Géza, ,, Mint szép ereklyével...” Balassi versének hasonlata, és ami mögötte rejtezik, Iskolakultúra, 2004/2, 36-49, föként 39. 
szempontjainak és változási jellemzőinek alávetetteket, hiszen bizonyos esetekben a változások ellenére nem kizárt, hogy éppen a szerzői szöveghez közelebb álló variánst hozzák, éppen azért, mert időben közelebb állnak a szereztetéshez.

S valóban, noha az 1602-15-ös kiadásban szereplő variáns 3. versszakát a kötet csonkasága miatt nem ismerjük, érdemes megfigyelni, hogy még az 1632-es gyülekezeti énekeskönyv is olyan változatot hoz, amely a radikálisabb unitárius hitelvekkel nem egyeztethető össze, ellenben pontosan olyanok a sorok, mint a későbbi Balassi-Rimay kiadásokban.

Nem kicsiny munkával, Fiad halálával váltottál meg:

kinek érdeméért most is szükségemet teljesitsd meg. ${ }^{635}$

A nyomtatott unitárius hagyományban tehát a későbbi szövegekkel tökéletesen egyező változat áll, s ez unitárius dogmatika szempontjából nem számít radikálisnak. A Kassai István énekgyüjteményében szereplő szöveg el is tér ettől, és a mondandót, - hogy Krisztus halálával érdemlettük ki az Úristen kegyelmét és az örök életet, - megváltoztatja, s már radikálisabb hitelveknek megfelelően hozza az éneket: Krisztus mint közvetítő, közbejáró szerepel a variánsban.

Nem kicsiny csodával, fiad halálával váltottál meg,

kérünk ö általa, minden szükségünket teljesitsd meg.

Megfigyelhetjük, hogy a kéziratot lejegyző változatában már nem is E./1.-ben szól a beszélő, hanem többes szám található a strófában, a gyülekezet együttes, mindenkire egyaránt érvényes kijelentésével találkozunk itt, nem a személyes kéréssel. A kollektivizálás tehát ebben az egy „Balassi-vers” (?) esetében először kéziratosan jelenik meg. Ebből is arra következtethetünk, hogy az első nyomtatott énekeskönyv anyaga még egy a szerzői változathoz viszonylag közelálló szöveg alapján készült, még nem mutatja a gyülekezeti éneklés okozta variálódás jellemzőit. Az 1629 körüli kézirat viszont már többes számot használva, az unitárius hitelveknek megfelelően alkalmazza a szövegrészt. Így továbbra is állni látszik, hogy az Adj már csendességet ... nem ugyanabból a hagyományágból került be az unitárius énekek közé, mint a Balassi-szövegek, hanem később lesz a gyülekezeti éneklés része, a szöveg később kollektivizálódik igazán.

Ezt a bemutatott dogmatikai változást egyébként a későbbi unitárius nyomtatványok is a Kassai-énekgyüjtemény lejegyzőjéhez hasonlóan igyekeznek használni, de más

${ }^{635}$ Az 1632-es kiadás alapján közöljük, de mivel igen csekély a kiadások közti szövegváltozás, így feltehetően a toldalékként az 1602-15 közötti nyomtatvány változatában is ugyanez volt. 
megoldásokkal: az 1697-es gyülekezeti énekeskönyvben ,kinek szent nevében most is szükségemet....” szerepel, az 1700-as magánhasználatra szánt énekeskönyvben pedig „,kinek sok kínjáért most is szükségemet..." áll.

Ebből az is látszik, hogy egy gyülekezeten - nemhogy felekezeten! - belül sem állandóak a szövegek. A 17. század elején a gyülekezeti énekgyüjteményekben szereplő Balassi- (és Rimay?) szövegek ugyanúgy az alapvetően a szóbeli hagyomány által kialakított variánsokkal rendelkeznek, mint a többi gyülekezeti ének.

\section{5. Összegzés}

Jelen fejezetben arra igyekeztünk rávilágítani, hogy néhány, csak a század 30-as éveitől (vagy még később) nyomtatásban megjelenő Istenes énekek-szöveg a 17. század első harmadában már a gyülekezeti éneklés része lett, és a szórványosan fennmaradt nyomtatványos vagy kéziratos variánsai arról tanúskodnak, hogy mindenki számára ismert, énekelt szövegekkel állunk szemben.

Talán éppen ezért, a széténeklés, a változatokban létezés miatt igyekeznek az Istenes énekek kiadói minél jobb, a szerzői változathoz közelebb lévő, a szövegeket állandósítani, rögzíteni próbáló kiadásokat készíteni, melyek tulajdonképpen magánhasználati énekeskönyvnek tekinthető kiadások lesznek a bennük szereplő, az Istent közvetlen, személyes hangnemben, a legtöbbször E./1.-ben megszólító verses szövegek által. ${ }^{636}$

Arra is igyekeztünk rámutatni, hogy a fennmaradt szegényes forrásoknak igen jelentős része köthető közvetlenül vagy közvetve a 17. század első harmadában Kolozsvárott működő kancelláriához, illetve a kolozsvári unitáriusokhoz. Így az sem kizárt, hogy valóban Petki János az a müvelt, irodalomkedvelö férfiú, akihez több Balassi (és Rimay?) szöveg jut el, de innen ezek a szövegek a saját életüket kezdik élni, kijutnak, közismertek, közkedveltek lesznek, s az unitárius gyülekezet énekli, mi több, széténekli azokat.

\footnotetext{
${ }^{636}$ Horváth Iván rámutat arra, hogy Balassi istenes témájú énekei a gyülekezeti ének múfaji konvencióit sértik meg a bünbánat személyességével, a kétkedő, kérdező hangnemmel. HoRVÁTH Iván, Balassi költészete történeti poétikai megközelitésben, Bp., Akadémiai 2004, 200-213. Ennek ellenére úgy tünik, hogy a korai, az Istenes énekek nyomtatott hagyománya előtti szövegváltozatok leküzdötték ezt a problémát a kollektivizálás által, és az unitárius éneklésben egészen biztosan megjelentek a szövegek. Talán emiatt nem volt érdektelen az összevetése a gyülekezeti anyaggal, hiszen ezáltal feltárultak azok a tendenciák, amelyekkel ezek a szövegek is az énekelt, orális hagyomány részei lehettek, még az Istenes énekek megjelenése előtt.
} 
Balassi szerelmi tárgyú szövegeinek popularizálódása először a 17. századi, főként nemesi környezetből ránk maradt kéziratos szerelmi lírára jellemzö, de ahogyan Csörsz Rumen István ${ }^{637}$ és Szilasi László ${ }^{638}$ is rámutatnak, ezek elsősorban nem a szövegek variálását jelentik, hanem a poétikai-retorikai minták hatottak.

Néhány istenes témájú Balassi-variáns azonban úgy tünik, hogy nagyon is „közkézen” forgott már az Istenes énekek megjelenése előtt a 17. század első 30 évében, a kolozsvári unitáriusok környezetében legalábbis egészen biztosan. Ám ezekben az esetekben nem a poétikai-retorikai minták hatása figyelhető meg elsősorban (noha a dolgozat néhány ilyen jellegü példát is szemléltetett), hanem néhány istenes ének erős variánsának szöveghagyományát regisztrálhatjuk.

A 17. század első harminc évében keletkező forrásokban szereplő összes istenes témájú Balassi-vers olyan kollektivizált, a gyülekezeti éneklésnek alávetett szövegváltozattal rendelkezik, amely az Istenes énekek egyik kiadásában sem jelenik meg a későbbiekben, így forrásul semmiképp nem szolgálhattak ezekhez.

\section{A dolgozat összegzése, kitekintési lehetőségek}

A dolgozatban igyekeztünk egyrészt néhány kiegészítést, apró adalékot szolgáltatni a 17. századi nyomtatott unitárius énekhagyományhoz (például az első énekeskönyv datálási problémái). Rámutattunk arra, hogy a Kochanowski-fordító zsoltárainak és az ismeretlen szerzőjü, csak unitárius forrásban megtalálható szövegeknek olyan közös poétikai-retorikai sajátosságaik vannak, amelyek alapján nem zárhatjuk ki azt, hogy egy szerző szerezte azokat.

A 17. század eleji unitárius kéziratos énekgyüjteményeket igyekeztünk jellemezni, s az előkerült újabb adatok fényében átgondolni az eddigi ismereteket például a Csonka antifonáléval, a Bölöni-kódexszel vagy a Vasady-kódexszel kapcsolatban.

Az unitárius forrásokban fellelhető énekek dogmatikai változtatásairól igyekeztünk bemutatni, hogy nem következetesek: noha a Szentháromság tagadását minden esetben megtaláljuk az unitárius szöveghagyományban, a nyíltan, közvetlenül radikális dogmatikát alkalmazó szövegváltozatok elsősorban a kéziratos hagyományban lesznek fellelhetők, a

${ }^{637}$ CSÖRSZ Rumen István, „Bujdosom szoros utakon” A régi magyar bujdosóénekek poétikája, I, Doromb, Közköltészeti tanulmányok 3,szerk. CsÖRSz Rumen István, Bp., reciti, 2014, 147. http://reciti.hu/wpcontent/uploads/08_Csorsz_Doromb3.pdf Letöltve: 2015.03.27.

${ }^{638}$ SZILASI, i.m. 
nyomtatott hagyomány ezt igyekszik egy-két énekre minimalizálni, illetve a radikális dogmatika irányába tett változtatásokat elkendőzve, finomabban alkalmazni.

Az unitárius énekgyüjtemény gyülekezeti énekeit összevetve a korábbi és a korabeli protestáns énekhagyománnyal, a dolgozat bemutatott néhány tendencia-szerüen kirajzolódó szövegváltozást. Ezek a jegyek azt mutatták, hogy a gyülekezeti énekek szövegváltozatainak kialakulása számos esetben nem ábrázolható stemmával. A gyülekezeti énekek szöveghagyományának vizsgálatakor mindenképp szükség van arra, hogy a hálózatos kapcsolatokat részesítsük előnyben, s emellett tekintettel legyünk a gyülekezeti ének mediális sajátosságaira, azaz arra, hogy írásban keletkezett szövegek élőszóban, éneklésben kezdenek el terjedni. Ezeket igyekeznek aztán az egyes felekezetek nyomtatott énekeskönyvekben rögzíteni, állandósítani, s e nyomtatott hagyomány mellett számos kéziratos gyüjtemény is keletkezik. A gyülekezeti énekek szövegének hagyományára a szerkesztő/kiadó/lejegyző irodalmi ízlése, dogmatikai ismerete és egy-egy általa ismert, énekelt variáns ismerete, emlékezete is hatással van.

Megfigyeltük, hogy a vélhetően nem az egyházi énekeskönyvek szolgai másolásával készült kéziratos énekgyüjtemények szövegváltozatai sokkal nagyobb variabilitást mutatnak, mint a nyomtatott hagyomány. Ám a nyomtatott hagyományban is találkozunk olyan szövegekkel, - s a számuk nem is csekély - amelyek olykor egy-egy felekezeten belül is komoly változásokat tartalmaznak.

Az egyes nyomtatványok közötti hálózatos kapcsolatokhoz a 118 ének vizsgálata az alábbi apró, de talán nem mellékes adalékokkal tudott hozzájárulni.

$\mathrm{Az}$ 1590-es debreceni református kiadásról az általunk vizsgált énekei alapján megállapítható, hogy a korábbi debreceni kiadásokon kívül Bornemisza Péter 1587-es gyülekezeti énekeskönyve is hatással volt rá, és a szövegei több ponton minden addigi gyülekezeti énekvariánstól eltérnek.

Az 1593-as bártfai evangélikus énekeskönyv variánsai ellenben nem csak a korábbi evangélikus kiadásokkal mutatnak rokonságot, hanem több ponton az 1590-es debreceni szövegváltozatokra hasonlít, illetve számos, addig nem ismert változtatást is tartalmaz.

Ugyanígy újítás figyelhető meg az 1602-14 közötti bártfai énekeskönyv énekeinél is a rímelésre irányuló törekvések például külön alfejezetben ismertetve lettek.

Az 1602-es debreceni református énekeskönyv esetében már Újfalvi Imre tudatos szerkesztői eljárásának mondható, hogy - előszavának célkitűzéseivel összhangban - kerüli a világi, széphistóriákra utaló nótajelzéseket, s a nótajelzést igyekszik a gyülekezeti énekanyagon belülről választani. A sok új nóta, ahogyan azt megfigyelhettük, egyre 
gyakrabban egyezik már szótagszám tekintetében azzal az énekkel, amelyhez nótajelzésként kerül. Újfalvi énekgyüjteményében a referenciális kolofonok mennyisége is észrevehetően csökken - feltehetően azért, mert Újfalvi felismeri, hogy a kollektív, együttes éneklésben az elavult évszámokat, a szerző nevét tartalmazó strófáknak már nincs jelentősége.

A nyomtatott unitárius énekgyüjtemények sajátosságait a megelőző protestáns gyüjteményekhez képest a következő állításokban foglalhatjuk össze:

1. Az unitárius énekanyag a protestáns hagyománytól a leginkább különböző, s ez a szövegkülönbség nem csak a dogmatikát érinti. (Ám dogmatikájukat tekintve a nyomtatványoknál jóval radikálisabb variánsokat közölnek az unitárius kéziratok.)

2. Az unitárius nyomtatványok szövegei a 17. század során igen kis mértékben változnak az újabb kiadásokban. A többi felekezet énekeskönyvei egymáshoz képest több eltérést tartalmaznak, mint az egyik unitárius énekeskönyv a másik unitáriushoz képest. Ebből és az unitárius nyomtatványok dogmatikai változásaiból is látható, hogy az unitárius gyüjteményeknek mindig volt „erős kezü” szerkesztője, a megjelenéskor feltehetően mindig volt „felső” kontroll. A megjelenési időből viszont látszik, hogy az unitárius énekeskönyvkiadások esetében nem elsősorban a kereskedelmi szempont volt a fontos: a hiány, a szükség, a növekvő igény vezetett egy-egy új kiadás megjelenéséhez.

3. Az 1602-15 közötti unitárius énekeskönyv az első magyar nyelvü protestáns énekeskönyv, amely már következetesen a protestáns zsoltárszámozást használja.

4. Az unitárius gyüjtemények sajátossága az ábécérendes szerkesztési elv, a szerkezet egyszerüsége, a címek jelentős rövidülése is.

5. Nótajelzés tekintetében az 1632-es, minden bizonnyal Thordai János által szerkesztett unitárius gyülekezeti énekeskönyv lesz az első, szinte következetesen egységes tendenciát alkalmazó gyüjtemény. Ebben az énekeskönyvben már általánossá válik, hogy a nótajelzés szótagszáma megegyezik az énekkel, amely előtt az adott nótajelzés található. Azt is bemutattuk, hogy ez az énekeskönyv és a Thordai-kódexben található Thordai-zsoltárok egymást hivatkozzák keresztbe nótajelzés tekintetében.

6. Az 1602-15 közötti gyülekezeti énekeskönyvben már alig találunk kolofont: az unitárius énekeskönyvekben minimalizálódik a kolofonok használata.

7. Szintén az unitárius nyomtatványok sajátossága, hogy jellemzően nem használnak záró doxológiát: nem veszik át, nem alakítják át, de a helyére sem tesznek új záró strófát.

8. Az unitárius anyagban igen kevés a krisztianizáló zsoltárparafrázis: ezek közül alig kerül át a protestáns hagyományból. Ez a tény talán párhuzamba hozható az unitáriusok azon 
törekvéséhez, hogy a bibliai értelemhez ragaszkodnak a zsoltárokban is. Megfigyeltük, hogy Sztárai zsoltárai helyett is inkább Kochanowski-fordítások szerepelnek az unitárius forrásokban. Az ellenség megtöréséről, levágásáról, tiprásáról szóló zsoltárhelyeket is finomítják az unitárius variánsok: föleg megtérítésről beszélnek.

Igyekeztünk arra is rámutatni, hogy a régi magyar vers jellemzői - pl. kolofon, akrosztichon, incipit, metrum és rím - nem minden esetben úgy változnak a gyülekezeti énekhagyományban, ahogyan azt logikusnak gondolhatnánk, azaz úgy, hogy az éneklést, az emlékezetben tartást segítsék.

Láttunk példát arra, hogy számos ének már a gyülekezeti hagyomány korai szakaszában is rontott, értelmetlen akrosztichonnal rendelkezik, s ezeket nem javítják a későbbi kiadások sem.

Láthattuk, hogy néhány ének rímtelen variánsban honosodik meg a gyülekezeti éneklésben annak ellenére, hogy néhány szórendcsere által szinte tökéletes rímes változat is énekelhető lenne. Ennek ellenére a gyülekezeti énekhagyományban ismertté vált, rímtelen változat hagyományozódik, nem változtatják vissza a rímes, könnyebben emlékezetben tarthatóra - noha kísérlet van rá, nem honosodik meg.

A szórendcserék, a bonyolultabb grammatikai viszonyban álló szavak, trópusok felsorolássá alakítása, az egyszerüsítő poétikai folyamatok mind-mind a gyülekezeti éneklés sajátjai, melyek a használatból fakadhatnak.

A vizsgált anyag alapján mondható, hogy a 17. század elejére tendenciózusnak tünik a kolofonok kikopása: a szerzőre, a szereztetésre utaló jegyek már nem szükségesek a közösségi énekekben.

Ugyanígy megfigyelhető egy-egy strófa, olykor egy egész ének kollektivizálása oly módon, hogy egyes szám első személyü elbeszélő helyett többes szám első személyre váltanak.

A hosszas exemplumokat, a vershelyzethez hasonló bibliai példákat tárgyaló strófák kikopása is praktikus okokra vezethető vissza: az ének rövidül általa, s a fö mondandóra koncentrál, emellett a zsoltárok esetében ezáltal a bibliai hűséget is jobban tartja. Mindemellett poétikai értelemben ezek szegényebb változatok lesznek.

A dolgozat utolsó fejezetében bemutatott korai Balassi-hagyomány, amely szinte csak unitárius forrásokban érhető tetten, ugyanezeket a tendenciákat mutatja. Az Istenes énekek megjelenése előtt néhány Balassi-szöveg már bekerült a gyülekezeti éneklésbe, ismertté, 
énekeltté vált, s a néhány fennmaradt rögzített variánsban jól látható hogy milyen, a gyülekezeti énekekre jellemző szövegváltozási tendencia érvényesül bennük még az Istenes énekek nyomtatott megjelenése előtt. Ezek alapján mondhatjuk, hogy még a szegényes forráshelyzet ellenére is látható: ezek a korai Balassi-variánsok nem rossz, romlott, vizsgálatra nem érdemes szövegek, hanem úgy kell azokat vizsgálni, mint a közösségi éneklésnek alávetett, a gyülekezet által énekelt, s emiatt változásoknak kitett variánsokat. Nem „rossz,” hanem gyakran használt, népszerü változatokról kell beszélnünk.

Noha dolgozatunkban egy kis korpuszt, 118 gyülekezeti éneket vizsgáltunk meg, kitekintésként, további kutatási lehetőségként már ezek alapján is megállapíthatjuk, hogy a Szeged-Budapest-Pécs-Kaposvár együttmüködéssel készülő RPHA 17 munkacsoportja jól döntött, amikor az adatrögzítés alapjait az RPHA módszerét követve, bár azt némileg módosítva a szövegvariánsokra helyezte. Mivel a 16-17. század magyar verses irodalmának java része istenes témájú, s emiatt a gyülekezeti éneklésben népszerü szöveg, a fent bemutatott változások feltehetően ezeken a szövegeken is érvényesülni fognak. Éppen ezért a régi magyar vers jellemző jegyeit gyakran már eleve elhagyott szövegeket látva - nehéz lenne főszöveget kiválasztani, s talán nincs is mindig értelme. Jó példa erre a bemutatott Szentháromság dicséret, amely legtöbbször unitárius forrásban fordult elö, természetesen nem Szentháromság dicséretként. Csak a cím és a lényegi mondandó kopott ki az editio princeps variánsához képest, mégis ez az erősen megváltozott variáns lesz a leggyakrabban másolt, nyomtatott a 17. században.

Reményeink szerint az RPHA 17 elkészültével születhetnek olyan tanulmányok, amelyek a gyülekezeti énekek egyes variánsait teljes értékü, egyenértékű szövegként tudják majd nagy - a mi dolgozatunknál sokkal nagyobb - számban vizsgálni, s a mediális sajátosságokat figyelembe véve új megközelítésben, az énekeltséget is a szövegváltozást befolyásoló jegynek véve nagy szövegkorpuszon érvényesülő tendenciákat mutatnak majd ki. 


\section{Irodalomjegyzék}

A kuruc küzdelmek költészete, kiad. VARGA Imre, Bp., Akadémiai, 1977.

ÁCs Pál, ,Elváltozott idők”, Bp., Balassi, 2006.

Armando, NuZzO, Balassi népszerüsitésének kezdetei: a bécsi kiadás, ItK, 1992, 639-645.

Balassi Bálint és Rimay János Istenes énekei, szerk. SzABÓ Géza, Bp., Helikon, 1983.

Balassi Bálint összes müvei,I, II, összeállította ECKHARDT Sándor, Bp., Akadémiai, 1959.

Balassi Bálint összes verse, hálózati kritikai kiadás, szerk. HORVÁTH Iván, TóTH Tünde, Gépeskönyv, 2002, ver. 2.0. http://magyar-irodalom.elte.hu/gepesk/bbom/itart.htm (Letöltve 2015. 09.01.)

BALÁzs Mihály, Altdorf és az erdélyi unitáriusok, Keresztény Magvető, 2012, 211-228.

BALÁzs Mihály, Az alkalmazás dilemmái, A német konfesszionalizációs modell és az erdélyi reformáció, Korall, 2014, 15.évf, 5-26.

BALÁzs Mihály, Néhány megjegyzés Heltai imádságos könyvének utóéletéről, Studia Litteraria, 2013/3-4. LII. évf. 298-317.

BALÁzs Mihály, Felekezetiség és fikció, Bp., Balassi, 2006, (Régi Magyar Könyvtár Tanulmányok 8).

BALÁzs Mihály, Jan Kochanowski és Balassi Bálint, Tiszatáj, 2012, 135. sz. Diákmelléklet, $1-16$.

BALÁzS Mihály, Teológia és irodalom, Az Erdélyen kívüli antitrinitarizmus kezdetei, Bp., Balassi, 1998 (Humanizmus és Reformáció 25).

BALÁzs Mihály, Dogmatischer Radikalismus und Ritualkonservatismus im siebenbürgischen Antitrinitarismus (16-17. Jahrhundert), kéziratban.

BALÁzs Mihály, Varsolci János és Rettegi György ismeretlen szövegeiröl, ItK 117(2013), 511.

BAlÁzS-Hajdu Péter - BognÁr Péter - Hevesi Andrea - Sinka Zsófia, Szegedi kisérlet a 17. századi magyar vers gépi feldolgozására, Filológia és Textológia a régi magyar irodalomban (konferenciakötet), szerk. KECSKEMÉTI Gábor, TASI Réka, Miskolci Egyetem BTK, Magyar Nyelv- és Irodalomtudományi Intézet, Miskolc, 2012, 461-470.

BogÁti FaZAKas Miklós, Psalterium, Magyar zsoltár, Kit az üdökbeli históriák értelme szerént különb-különb magyar ékes nótákra, az Isten gyülekezetinek javára fordított Bogáti 
Fazakas Miklós, a szöveget gondozta GILICZE Gábor, SzABÓ Géza, utószó DÁN Róbert, Magyar Helikon, 1979, 243.

CsOMASZ TóTH Kálmán, A prágai Gálszécsi-töredék énekei, ItK, 1970. 51-59.

CsOMASz TóTH Kálmán, Régi Magyar Dallamok Tára I, A XVI. század magyar dallamai, Bp., Akadémiai, 1958.

CsOMASz Tóth Kálmán: A református gyülekezeti éneklés, 1950.

CSÖRSZ Rumen István, „Bujdosom szoros utakon” A régi magyar bujdosóénekek poétikája = Doromb, Közköltészeti tanulmányok 3, szerk. CsöRsz Rumen István, Bp., reciti, 2014, 147. http://reciti.hu/wp-content/uploads/08_Csorsz_Doromb3.pdf Letöltve: 2015.03.27.

CsÖRSz Rumen István, Közköltészet - irodalom alatt, kultúrák fölött, Literatura, 2006. 2. 32. évf. 273-282.

CSÖRSZ Rumen István, Rákóczi halála nagypénteken - Mikestöl a közköltészetig = Író a számüzetésben: Mikes Kelemen, szerk. TÜSKÉS Gábor, munkatársak: CsÖRSZ Rumen István, Hegedüs Béla, LENGYEL Réka, Bp., Universitas, 2012, 226-236 (Historia Litteraria 28).

CsÖRsz Rumen István, Szöveg szöveg hátán, A magyar költészet variációs rendszere 1700 1840, Bp., Argumentum, 2009 (Irodalomtörténeti füzetek 165).

DAMJÁN István, Abrugyi György, MKSz 1902, 159-161. (A kézirat leírása.)

DeBRECZENI Sándor, A Vasady-kódex eredete, Keresztény Magvető, 1940, 247-250.

DÉzsI Lajos, A Vasady-kódex, ItK, 1913, 14-27.

DÉZSI Lajos, Régi magyar verseskönyveink ismertetése, VII, A Detsi-kódex, ItK, 1927, 68-76.

DÉZSI Lajos, Régi magyar verseskönyvek ismertetése V, A Kuun-kódex, ItK, 1916, 50-74.

DÉZSI Lajos, Régi magyar verseskönyvek ismertetése, VI, A Lipcsei-kódex, ItK, 1916/3, 305343.

Die Bibel oder die ganze Heilige Schrift des Alten und Neuen Testaments (Nach der deutschen Übersetzung Martin Luthers), Württembergische Bibelanstalt Stuttgart, 1968.

Domokos Pál Péter, Tatrosy György önéletírása és történeti feljegyzései, ItK, 1957, 238-261

Erdélyi magyar szótörténeti tár, XIII. kötet, SzABÓ T. Attila, Kolozsvár, EME, 2009, 772-73, unszolás szócikk.

ETLINGER Mihály, A tyúk vagy a tojás? = Mikro\&Makro, Fiatal Kutatók Konferenciája Tanulmánykötet, Bp., 2013, 111-124 (Arianna Könyvek 6).

FEKETE Csaba, A 16-17. század legkisebb imádságoskönyve = Régi magyar imakönyvek és imádságok, Pázmány Irodalmi Mühely, Lelkiségtörténeti tanulmányok, szerk. BoGÁR Judit, 
Pázmány Péter Katolikus Egyetem, Bölcsészet- és Társadalomtudományi kar, Piliscsaba, 2012,91-103.

Letöltés:https://btk.ppke.hu/uploads/articles/19896/file/regi magyar imakonyvek es imadsa gok.pdf (Letöltve 2014. 10. 11.)

FERENCZI Zoltán, Cserei Mihály néhány ismeretlen verse1690-98-ból, ItK, 1891 /4, 437-455.

Gyarmati Balassa Bálintnak istenes éneki, Bécs, 1633, kísérő tanulmány Armando Nuzzo, Bp., Balassi - MTA ITI, 1994 (BHA XXX).

GYÖNGYÖSI István, Porábúl megéledett Fönix, avagy a néhai gyerömonsotori Kemény János erdélyi fejedelemnek Lónyai Anna asszonyal lévő házasságának..., kiadja JANKOVICS József, NYERGES Judit, Balassi Kiadó, é.n. http://www.balassikiado.hu/BB/netre/html/fonix/phonix.html Letöltve: 2015. 02.04.

Heltai Gáspár imádságos könyve (1570-1571), közzéteszi BALÁzs Mihály, Erdélyi Unitárius Egyház, Kolozsvár, 2006 (Az Erdélyi Unitárius Egyház Gyüjtőlevéltárának és Nagykönyvtárának kiadványai 5).

H. HUBERT Gabriella, 1602: Megjelenik Újfalvi Imre énekeskönyve = A magyar irodalom történetei, A kezdetektöl 1880-ig, szerk. JANKOVITS László, ORLOVsZKY Géza, Bp., Gondolat Kiadó, 2007, 382-393.

H. HuBERT Gabriella, A régi magyar gyülekezeti ének, Budapest, Universitas, 2004. (Historia Litteraria 17.)

H. HUBERT GABRIELLA, Balassi Istenes énekeinek legelső kiadása? MKSz, 1995, 169-172.

HEREPEI János, Adatok a Régi Magyar Könyvtár I. és II. kötetéhez, ErdM 1939, 276-284.

HEREPEI János, Adatok régi magyar versekröl, ItK, 1962/4, 477-493.

HEVESI Andrea, Adalékok a Bölöni-kódex történetéhez, ItK, megjelenés alatt.

HEVESI Andrea, RMNy 1615. Egy unitárius ima-énekeskönyv töredéke, a többi 17. századi unitárius énekeskönyv tükrében, Keresztény Magvetö, 2013/4, 377-390.

HEVESI Andrea, Újfalvi Imre: egy protestáns értelmiségi karrier a 16-17. század fordulóján = Értelmiségi karriertörténetek, kapcsolathálók, irócsoportosulások, szerk. BIRÓ Annamária BoKA László, Nagyvárad - Budapest, Partium Kiadó - reciti, 2014, 31-40.

HoPP Lajos - Jan SLASKI, A magyar-lengyel múltszemlélet elözményei, (Politikai és kulturális hagyományok Báthory Istvánig), Bp., Tankönyvkiadó, 1992.

HoRVÁTH Iván, Balassi költészete történeti poétikai megközelitésben, Bp., Akadémiai, 1982.

HoRVÁTH Iván, Balassi költészete történeti poétikai megközelítésben, Bp., Akadémiai 2004.

HORVÁTH Iván, Egy vita elhárítása, ItK, 1987-88, 642-665. 
HORVÁTH Iván, Szöveg, http://magyar-irodalom.elte.hu/gepesk/bbom/tanulm/hiszoveg.htm (Letöltve: 2015. 09.01.)

HUBERT Gabriella, Gyülekezeti énekek müfaja: van-e rendszert az adatokban?, ItK, 1989, 298-305.

IMRE Mihály, „Magyarország panasza” A Querela Hungariae toposz a XVI-XVII. század irodalmában, Debrecen, Kossuth Kiadó, 1995 (Csokonai Könyvtár 5).

JAKAB Elek, Adatok énekeskönyveink bibliographiájához, MKSz, 1882 40-71.

Jan SLASKI, Balassi Bálint és a lengyelek, ItK, 1999, 655-660.

JENEY-TóTH Annamária, Míves emberek a kincses Kolozsvárott, Erdélyi Múzeum Egyesület, Kolozsvár, 2004.

KANYARÓ Ferenc, A legrégibb unitárius énekeskönyvekröl, MKSz, 1895, 321-332.

KANYARÓ Ferenc, Abrugyi György könyvnyomtatónk zsoltárforditó-é? KerMagv. 1908, 2704. (DAMJÁN cikkének helyesbítései.)

KANYARÓ Ferenc, Enyedi György unitárius püspök beszéde, Keresztény Magvető, 1900, 3040.

KEMÉNY János, Önéletírása, kiad. SzALAY László, Pest, 1856.

KÉNOSI TÖZSÉR János - UZONI FOSZTÓ István, Az erdélyi unitárius egyház története I, ford. MÁRKOS Albert, a bevezető tanulmányt írta BALÁzs Mihály, sajtó alá rendezte HoFFMANN Gizella, KovÁCs Sándor, MolNÁR B. Lehel, Erdélyi Unitárius Egyház, Kolozsvár, 2005.

KESERÜ Gizella, Az erdélyi unitárius egyház megkésett konfesszionalizálódása és a lengyel testvérek a 17. század elején = „Nem sülyed az emberiség!” Album amicorum Szörényi László LX. születésnapjára, föszerk. JANKOVICS József, MTA ITI, Bp., 2007, 429-449. http://www.iti.mta.hu/Szorenyi60/Keseru_Gizella.pdf Letöltve: 2015. 03.09.

KLANICZAY Tibor, Hozzászólás Balassi és Rimay verseinek kritikai kiadásaihoz, MTA I. OK. 1957, 263-338.

KLANICZAY Tibor, Reneszánsz és barokk, Bp., 1961.

KORZENSZKY Richárd, Kassai István énekgyüjteménye, Pannonhalma, 1997, (Pannonhalmi füzetek 41).

KovÁCs Sándor, Das Abendmahl in der unitarischen Liturgie des 16. und 17. Jahrhunderts = Radikale Reformation, Die Unitarier in Siebenbürgen, Böhlau Verlag, Köln, Weimar, Wien, 2013, 241-28. (Studia Transylvanica 44).

KovÁCs Sándor Iván, Szelence - kemence - Velence, Egy Rimay-rímtoposz diadalmenete és bukása, Újhold évkönyv, 1988/1. 362-385. 
KöSZEGHY Péter, Balassi Bálint, Magyar Amphión, Bp., Balassi, 2014.

KÖSZEGHY Péter, Elháritva (Megjegyzések Horváth Iván: Egy vita elháritása címü cikkéhez), ItK, 1989, 597-604.

KöSZEGHY Péter, Horváth Iván: Balassi költészete történeti poétikai megközelitésben, ItK 1987-88. 310- 338.

krúda - szócikk in: Magyar Müvelödéstörténeti Lexikon LX. minden kor, a föszerkesztö Köszeghy Péter hatvanadik születésnapjára, szerkesztette: BARTóK István, CsÖRSz Rumen István, JANKOviCs József, SzENTMÁRTONI SzABÓ Géza, Balassi Kiadó, Budapest 2011. 116120. = Mikor jelent meg Balassi Bálint Istenes énekinek bécsi kiadása? (Egy 1991-es pécsi előadás megírt változata.)

LATZKOviTs Miklós, Régi magyar dráma és szöveghagyomány, PhD értekezés, Szeged, 1997.

Martin, LUTHER, Ausgewaelte Schriften predigten Tischreden Briefe und Lieder mit einem Vormort von Wilhelm Schaefer, Deutsche Buch-Gemeinschaft G.m.b.h. Berlin, o. J.

Magyarország zenetörténete II, 1541-1686, szerk. BÁRDOS Kornél, Bp., Akadémiai, 1990, 201-11.

MolnáR B. Lehel, A háromszéki unitáriusok 17. századi történetéhez. Toposz és valóság közt, KerMagv 118 (2012) 245-275.

MoLNÁR Dávid, „Scrabei per telas aranearum” A 17. század eleji erdélyi unitárius egyház eltussolt története? - kéziratban.

MolnÁR Dávid, Kmita Andrásné, a kolozsvári unitárius egyház nyomdájának felállitója. Adalékok a nyomda történetéhez - kéziratban.

MOLNÁR Dávid, Református-unitárius templomviták (1615-1648), Keresztény Magvető, 2014/1. 3-21.

MoLNÁR Dávid, Valentin Radecke, Radecke életpályája püspökké választásától plébánossá választásáig (1615-1622), Keresztény Magvető, 121 (2015), megjelenés alatt.

NeMESKÜRTY István, Bornemisza Péter: Cantio optima $=A$ régi magyar vers, szerk. KomlovszKi Tibor, Bp., Akadémiai, 1979, 91-101.

NORFOLK, Lawrence, A Lempriére-lexikon, ford. Gy. HoRvÁTH László, 2. kiadás, Bp., Athenaeum 2000 kiadó, é.n.

OlÁH Szabolcs, Hitélmény és tanközlés, Bornemisza Péter gyülekezeti énekhasználata, Debrecen, Csokonai Universitas Könyvtár, Kossuth Egyetemi Kiadó, 2000 (Bibliotheca Studiorum Litterarium 22).

ÖTVÖs Péter, Rimay Balassi-kiadásának tervéhez, Egy meg nem kapott levél, ItK, 1990, 8187. 
Péter, ÖTVÖs, Preussen christliche Lieder in der unitarischen Gemeinde von Klausenburg, Bemerkungen zu dem Thema Unitarier und Spiritualisten in Siebenbürgen = György Enyedi and Central European unitarism in the 16-17th centuries, ed. Mihály, BALÁzS; Gizella, KESERÜ, Bp., Balassi, 2000, 259-268.

PAP Balázs, Az Istenes énekek margóira = GHESAURUS, Tanulmányok Szentmártoni Szabó Géza hatvanadik születésnapjára, szerk. CsöRsz Rumen István, rec.iti, Bp., 2010, 335-342. Letöltve: 2015. 03. 19-én. http://plone.iti.mta.hu/rec.iti/Members/szerk/ghesaurus1/PapBalazs-Ghesaurus.pdf

PAP Balázs, Históriák és énekek, Pécs, 2014 (Pannónia Könyvek).

PAPP Géza, Ismeretlen Kochanowski-fordítások a XVI.-XVII. századból, ItK, 1961, 328-340.

PAPP Géza, Thordai János lengyel dallammintája, ItK, 1966. 208-210.

PERGER Péter, A kolozsvári unitárius egyház nyomdájáról való számvetés = Fata libelli a nyolcvanéves Borsa Gedeon köszöntésére, Budapest, Országos Széchényi Könyvtár, 2003, 289-304.

PERGER Péter, Egy 17. századi nyomdafelszerelés útja Bécstöl Kolozsvárig = A magyar grafika 5 éve, http://epa.oszk.hu/00800/00892/00033/pdf/11.pdf (Letöltve: 2015. 04. 28).

PIRNÁT Antal, Balassi Bálint poétikája, Bp., Balassi, 1996 (Humanizmus és reformáció 24).

Régi Magyar Költök Tára 17. század, 4, Az unitáriusok költészete, kiad. STOLL Béla, TARNÓC Márton, VARGA Imre, Bp., Akadémiai, 1967. (RMKT 17/4.)

Régi Magyar Költök Tára XVIII. század, IV. kötet, Közöltészet, 1. Mulattatók, s.a.r. KüLlöS Imola, munkatárs CsÖRsz Rumen István, Bp., Balassi, 2000.

Régi Magyar Könyvtár, I-II, SzABÓ Károly, HelleBRANT Árpád, 1879-1885, Bp.

Régi Magyar Könyvtár, III, SzABÓ Károly, HelleBRANT Árpád, 1896-98, Bp.

Régi Magyarországi Nyomtatványok, (1473-1600), I, Bp., Akadémiai, 1971. (RMNy)

Régi Magyarországi Nyomtatványok, (1601-1635), II, Bp., Akadémiai, 1983. (RMNy)

Régi Magyarországi Nyomtatványok, (1636-1655), III, Bp., Akadémiai, 2000. (RMNy)

Régi Magyarországi Nyomtatványok, (1656-1670), IV, Bp., Akadémiai, 2012. (RMNy)

Rimay János írásai, szöveggondozás és utószó, Ács Pál, Bp., Balassi, 1992.

Répertoire de la poésie hongroise ancienne, I, II, Iván HoRVÁTH, Paris, Nouel Object, 1992.

Répertoire de la poésie hongroise ancienne, HORVÁTH Iván, 1992-2001. http://rpha.elte.hu/ (Letöltve 2015.01.03.) 
SCHULEK Tibor, Még néhány szó és egy új adat Szilvásújfalvi Imréröl = Szenci Molnár Albert és a magyar késö-reneszánsz, szerk. CsANDA Sándor, KESERÜ Bálint, Szeged, 1978, 293-96 (295) (Adattár 4).

SINKA Zsófia, Adalékok a Balassi-Rimay szöveghagyományhoz = Filológia és textológia a régi magyar irodalomban, szerk. KECSKEMÉTI Gábor, TASI Réka, Miskolci Egyetem BTK Magyar Nyelv- és Irodalomtudományi Intézet, Miskolc, 2012, 387-395.

STOLl Béla, A magyar kéziratos énekeskönyvek és versgyüjtemények bibliográfiája (15421840), Bp., Balassi, 2. kiad., 2002. (S)

STOLl Béla, Közösségi költészet - népköltészet. Megjegyzések a XVII.[A kiadásban félrenyomva 18.-ra] századi kéziratos szerelmi lírához, ItK, 1958, 170-176.

SzABÓ T. Attila, Adatok Felvinczi György életéhez és irodalmi munkásságához, ItK, 1933, 141-145.

SZALAI Béla, Egy könyvészetileg ismeretlen debreceni református énekeskönyv 1610-böl, kéziratban.

SZEGEDI Edit, Die Bedeutung des Ungarischen und Sächsischen im Klausenburg des 16. bis 17. Jahrhunderts $=$ Radikale Reformation, Die Unitarier in Siebenbürgen, Böhlau Verlag, Köln, Weimar, Wien, 2013, 179-189. (Studia Transylvanica 44).

SzEGEDI Edit, Valentin Radecius és az egyházi hagyomány legitimitása, Keresztény Magvető, 2011/3, 284-297.

SZELESTEI N. László, Az Erdödy-énekeskönyv, ItK, 1978, 83-94.

SZENTMÁRTONi SZABÓ Géza, „Mint szép ereklyével...” Balassi versének hasonlata, és ami mögötte rejtezik, Iskolakultúra, 2004/2, 36-49.

SzIGETI Csaba, A Rimay-vershagyomány a XVII. században, ItK, 1982(86), 5/6, 614-619.

SzIGETI Csaba, Appendix Balassiana, Kronológia, tradíció, hagyománytudat a XVII. századi Balassi-követö nemesi költészetben, ItK, 1985(89) 6, 675-687.

SZILASI László, A sas és az apró madarak, Balassi Bálint költői nyelvének utóélete a XVII. század első harmadában, Bp., Balassi, 2008, 29 (Humanizmus és reformáció 30).

TARNAI Andor, Nemesi költészet = A magyar irodalom története, II, szerk. Klaniczay Tibor, Bp., Akadémiai, 1964, 440-441.

ThIENEMANN Tivadar, Irodalomtörténeti alapfogalmak, Pécs, Danubia, 1931.

TóTH György, Az unitárius egyház rendszabályai (1626-1850), Kolozsvár, 1922.

VADAI István, Hozzászólás a Hozzászóláshoz = A szerelem költői, szerk. SzENTMÁRTONI SzABÓ Géza, Bp., Universitas, 2007, 141-175. 
VADAI István, 1554: Megjelenik Tinódi Cronicája, A tudósító ének müfaja = A magyar irodalom történetei, A kezdetektöl 1800-ig, Bp., Gondolat, 2008, 274-285.

VADAI István, Balassi Bálint fajtalan éneki, ItK, 1994, 673- 681

VADAI István, Balassi, Rimay és Szenci Kertész Ábrahám - Az istenes énekek kiadástörténetének új modellje, előadás az MTA ITI Reneszánsz Osztályán, 2015. 02. 24-én, ugyanez az előadás elhangzott Szegeden, 2015.03. 3-án.

VADAI István, Szóban kettö - írva négy. Az oralitás metrikájáról, = Doromb: közköltészeti tanulmányok, 1, szerk. CsÖRSZ Rumen István, Bp., reciti, 2012. http://www.reciti.hu/wpcontent/uploads/05 Vadai.pdf Letöltve: 2015. 05. 12

VÁRfAlVi NAGY János, Az unitáriusok énekes-könyveiről, Keresztény Magvető, 1871, 93126.

VARGA Imre, Thordai János zsoltárainak forrásáról, manierizmusáról, ItK, 1968, 541-554.

VISKY István, Szilvásújfalvi Imre pere, A 17. századi váradi református egyházkormányzati reformmozgalom története, Várad, 2004./3. 3. évf. Interneten: http://epa.oszk.hu/00100/00181/00013/23.htm (Letöltve 2013.06.04.)

ZENTAI Mária, Rimay hatás Thordai János zsoltáraiban = Acta Historiae Litterarum Hungaricarum, Tomus XIII. Szeged, 1973, 111-123.

\section{A gyülekezeti énekek összevetéséhez felhasznált primer szövegek forrásai, facsimiléi:}

A keresztyéni gyülekezetben való isteni dicséretek, Várad, 1566, szöveggondozás VARJAS Béla, kísérő tanulmány ScHULEK Tibor, Bp., Akadémiai, 1975 (Bibliotheca Hungarica Antiqua IX).

A keresztyéni gyülekezetben való isteni dicséretek.... 1593, Bártfa, (RMNy 713), az OSZK példányát tudtam kézbe venni.

A Kuun-kódex, I-II, s.a.r. VARGA Imre, Bp., 1979. (Facsimile és átirat)

Balassa-kódex, facsimile, közzéteszi KöSzEGHY Péter, VADAI István, Bp., Balassi, 1994. (S76) 
BORNEMISZA Péter, Énekek három rendben, Detrekő, 1582, kísérő tanulmány KovÁCS Sándor Iván, szöveggondozás VARJAS Béla, Bp., 1964 (BHA VI).

Bölöni-kódex (S 30), OSZK Oct. Hung. 642.

Csonka antifonálé (S143), Kolozsvár, Akadémiai Könyvtár, MSU 996.

Detsi-kódex (S 25), MTAK K64.

Énekeskönyv, 1570, Debrecen, (RMNy 276), MTAKK.

Énekeskönyv, 1590, Debrecen, (RMNy 640), az egyetlen csonka kolozsvári példány fotómásolatát Pap Balázs bocsátotta a rendelkezésemre.

Énekeskönyv, 1602-14, Bártfa, (RMNy 965), OSZK.

Énekeskönyv, 1602-15, Kolozsvár, (RMNy 983), Marosvásárhely, Teleki Téka. (A mikrofilológiai kiegészítésekhez az OSZK mikrofilmjét is használtuk.)

Énekeskönyv, melyből szoktanak... 1569, Debrecen, (RMNy 264), Kolozsvár, EK.

Énekeskönyv, melyböl szoktanak... 1579, Debrecen, (RMNy 429), Kolozsvár, a fotómásolatokat Pap Balázs bocsátotta a rendelkezésemre.

Huszár Gál énekeskönyve, 1560-61, szöveggondozás VARJAS Béla, kísérő tanulmány BoRSA Gedeon, Bp., 1983 (Bibliotheca Hungarica Antiqua, XII).

HuszÁr Gál, A keresztyéni gyülekezetben való isteni dicséretek és imádságok, Komjáti, 1574, közzéteszi KőSzEGHY Péter, kísérő tanulmány HuBERT Gabriella, Bp., MTA ITI, 1986 (BHA XIII).

Imádságos és énekes... 1635, Kolozsvár, (RMNy 1615), OSZK. 
Imádságos és énekes... 1700, Kolozsvár (RMK I, 1558-59), a kolozsvári Akadémiai Könyvtár példányai alapján.

In exequiis defunctorum... 1660, Kolozsvár (RMNy 2903), a kolozsvári Akadémiai Könyvtár egyetlen példánya, és a közben előkerült lappangó példány alapján.

In exequiis defunctorum... 1697, Kolozsvár (RMK I, 1504), a kolozsvári példányok alapján.

Isteni dicséretek, imádságos és vigasztaló énekek, 1632, Kolozsvár (RMNy 1541), a kolozsvári Akadémiai Könyvtár példányai.

Isteni dicséretek, imádságos és... 1697, Kolozsvár (RMK I, 1503), a kolozsvári példányok alapján.

Keresztyéni isteni dicséretek, melyekkel... 1640, Bártfa, (RMNy 1816), az OSZK mikrofilmmásolata alapján.

KORZENSZKY Richárd, Kassai István énekgyüjteménye, Pannonhalma, 1997, (Pannonhalmi füzetek 41).

Szenci MolnÁR Albert, Szent Biblia azaz... Oppenheim, 1612. RMNy 1037. (A zsoltárok után található énekválogatást a kolozsvári Akadémiai Könyvtár példányai alapján vetettük össze.)

SZILÁDY Áron, Énekes könyv... Bp., 1893. (Az 1569-es debreceni énekeskönyv álfacsimiléje.)

ÚJfalvi Imre, Keresztyéni énekek, 1602, Debrecen, kísérő tanulmány Ács Pál, Bp., Balassi, 2004 (BHA 38).

Vasady-kódex (S 27) megsemmisült, némely szöveg másolata Dézsi Lajos hagyatékából, SZTE EK MS 620; MS 834. 